\title{
Diastereoselection in the Formation of
}

\section{Contiguous Quaternary Carbon Stereocenters by the Intramolecular Heck Reaction}

\author{
Larry E. Overman and Donald A. Watson \\ Department of Chemistry, 516 Rowland Hall, University of California, Irvine, \\ California, 92697-2025 \\ leoverma@uci.edu
}

Supporting Information

Index:

Page

Experimental Details

S2

Crystallographic Data

S18

Spectral and Chromatographic Data 


\section{Experimental Details:}

General Experimental Details. All reactions, except for those employing water as solvent or reagent, were performed in oven dried $\left(180{ }^{\circ} \mathrm{C}, 12 \mathrm{~h}\right)$ glassware. Concentrations were performed under reduced pressure $(c a .15 \mathrm{~mm})$ with a rotary evaporator. Argon used was ultra-high-grade. THF, $\mathrm{Et}_{2} \mathrm{O}, \mathrm{CH}_{2} \mathrm{Cl}_{2}$, DMF and $\mathrm{PhMe}$ were dried according to published procedures. ${ }^{1} \mathrm{MeOH}$ was distilled from $\mathrm{Mg}$ turnings. Triethylamine and benzene were distilled from $\mathrm{CaH}_{2}$. DMA was purchased anhydrous and degassed before use. $\operatorname{Pd}\left(\mathrm{PPh}_{3}\right)_{2} \mathrm{Cl}_{2}$ was prepared according to published procedures. ${ }^{2}$ All other reagents and solvents were purchased at highest commercial quality and used as received.

Instrumentation and chromatography: $500 \mathrm{MHz}{ }^{1} \mathrm{H}$ and $125 \mathrm{MHz}{ }^{13} \mathrm{C}$ NMR spectra were obtained on $500 \mathrm{MHz}$ FT-NMR spectrometers in the indicated deutero-solvent. Chemical shifts are reported in ppm using the residual protio-solvent as a standard for ${ }^{1} \mathrm{H}$ NMR and the ${ }^{13} \mathrm{C}$ signal of the deutero-solvent as a standard ${ }^{13} \mathrm{C}$ NMR. All NMR spectra were recorded at ambient temperature unless otherwise noted. Multiplicity is indicated as follows: s (singlet); $\mathrm{d}$ (doublet); $\mathrm{t}$ (triplet); q (quartet); m (multiplet); dd (doublet of doublets); dt (doublet of triplets); td (triplet of doublets); ddd (doublet of doublets of doublets); dddd (doublet of doublets of doublets of doublets); $b$ denotes a broad single. IR spectra were obtained on FT-IR spectrometers as thin films. Column chromatography was performed with $43-60 \mu \mathrm{m}$ silica gel. The eluent used is reported in parentheses. Analytical thin-layer chromatography (TLC) was performed on precoated glass-backed plates. High pressure chromatography (HPLC) was preformed using the denoted column type and eluent. Mass spectrometry ionization techniques experiments are abbreviated as follows: chemical ionization (CI), electron impact ionization $(\mathrm{EI})$, fast atom bombardment $(\mathrm{FAB})$ and electrospray ionization (ESI)

\footnotetext{
${ }^{1}$ Pangborn, A. B.; Giardello, M. A.; Grubbs, R. H.; Rosen, R. K.; Timmers, F. J. Organometallics, 1996, $15,1518$.

${ }^{2}$ Heck, R. F. Palladium Reagents in Organic Synthesis; Acedemic: New York, 1985; p 18.
} 
Diol 6. Trimethylsilyl triflate $(4.57 \mathrm{~g}, 20.6 \mathrm{mmol})$ was added dropwise

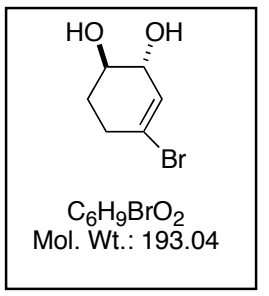
to a stirred solution of 3-bromo-cyclohexenone $\mathrm{s}^{3}(3.00 \mathrm{~g}, 17.1 \mathrm{mmol}$, previously azetropically dried from $\mathrm{PhH}$ ) and $\mathrm{Et}_{3} \mathrm{~N}(3.47 \mathrm{~g}, 4.77 \mathrm{~mL}$, $34.3 \mathrm{mmol})$ in $\mathrm{CH}_{2} \mathrm{Cl}_{2}(90 \mathrm{~mL})$ at $-78{ }^{\circ} \mathrm{C}$. The resulting solution was maintained at $-78{ }^{\circ} \mathrm{C}$ for $4 \mathrm{~h}$ before being poured in to a room temperature saturated aqueous $\mathrm{NaHCO}_{3}(200 \mathrm{~mL}$,). The layers were separated. The organic phase was washed with brine $(100 \mathrm{~mL})$, dried $\left(\mathrm{MgSO}_{4}\right)$ and concentrated in vacuo. The resulting crude oil (silyl enol ether) was placed under vacuum for $\mathrm{ca}$. $1 \mathrm{~h}$ before proceeding but used without further purification.

The silyl enol ether was then dissolved in $\mathrm{CH}_{2} \mathrm{Cl}_{2}(80 \mathrm{~mL}) . \mathrm{NaHCO}_{3}(3.0 \mathrm{~g}$, anhydrous) was added and the resulting suspension was cooled to $0{ }^{\circ} \mathrm{C}$. metaChloroperbenzoic acid (3.25 g, $18.9 \mathrm{mmol}$, anhydrous, recrystallized) was then added and the resulting suspension was rapidly stirred for $1 \mathrm{~h}$. During this time the reaction becomes noticeable more cloudy. After $1 \mathrm{~h}$, TLC analysis shows no remaining starting material. The reaction was quenched by the addition of $1 \mathrm{M}$ aqueous $\mathrm{Na}_{2} \mathrm{~S}_{2} \mathrm{O}_{3}(80 \mathrm{~mL})$. The resulting biphasic solution was rapidly stirred for $1 \mathrm{~h}$. The layers were then separated and the organic phase was returned to the flask. $\mathrm{MeOH}(3 \mathrm{~mL})$ and aqueous $\mathrm{HCl}$ (5 drops, concentrated) were then added and the resulting biphasic solution was rapidly stirred until TLC analysis indicated complete removal of the silyl group ( $c a .30 \mathrm{~min}$ ). The reaction was then quenched by the careful addition of saturated aqueous $\mathrm{NaHCO}_{3}(80 \mathrm{~mL})$. The layers were separated and the aqueous phase was washed with $\mathrm{CH}_{2} \mathrm{Cl}_{2}(2 \times 20 \mathrm{~mL})$. The combined organics were washed with brine $(100 \mathrm{~mL})$, dried $\left(\mathrm{MgSO}_{4}\right)$ and concentrated in vacuo to give the crude $\alpha$-keto-alcohol as an unstable yellow oil. This material was used without further purification.

The crude keto-alcohol was then dissolved in THF $(80 \mathrm{~mL}) . \mathrm{NaBH}(\mathrm{OAc})_{3}(3.63$ $\mathrm{g}, 34.3 \mathrm{mmol}$ ) was then added in one portion and the resulting suspension was rapidly stirred at room temperature for $12 \mathrm{~h}$. After this time, TLC analysis indicated complete reduction and the reaction was quenched by the addition of water $(50 \mathrm{~mL})$. The reaction was the extracted with EtOAc $(3 \times 100 \mathrm{~mL})$. The combined organics were washed with brine $(100 \mathrm{~mL})$, dried $\left(\mathrm{MgSO}_{4}\right)$ and concentrated in vacuo to give the crude diol as a yellow. ${ }^{1} \mathrm{H}$ NMR analysis of the crude reaction mixture indicated that diastereoselectivity in reduction was greater than 10:1 in favor of the trans isomer. The product was purified by recrystallization (EtOAc-hexanes) to give $1.83 \mathrm{~g}$ (55\%, from 3-bromo-cyclohexenone) of isomerically pure diol $\mathbf{6}$ as colorless prisms. The analytical data for this compound matched that previously reported. ${ }^{4}$

\footnotetext{
${ }^{3}$ Piers, E.; Nagakura, I. Synth. Commun. 1975, 5, 193-199.

${ }^{4}$ Banwell, M. G.; Lambert, J. N.; Richards, S. L. Aust. J. Chem. 1991, 44, 939-950.
} 


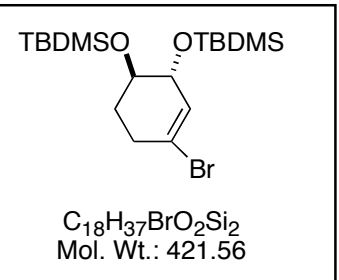

Disilyl Ether 7. tert-Butyldimethylsilyl triflate $(8.22 \mathrm{~g}, 31.1$ mmol) was added dropwise to a solution of diol $6(2.00 \mathrm{~g}, 10.4$ mmol) and 2,6-lutidine (5.55 g, $7.14 \mathrm{~mL}, 51.8 \mathrm{mmol})$ in $\mathrm{CH}_{2} \mathrm{Cl}_{2}$ $(100 \mathrm{~mL})$ at $0{ }^{\circ} \mathrm{C}$. After $1 \mathrm{~h}$, TLC analysis indicated the reaction was complete. The reaction was quenched by the addition of saturated aqueous $\mathrm{NaHCO}_{3}(100 \mathrm{~mL})$ and the resultant layers were separated. The organic phase was washed with $1 \mathrm{M}$ aqueous citric acid $(1 \times 100 \mathrm{~mL})$, saturated aqueous $\mathrm{NaHCO}_{3}(1 \times 100 \mathrm{~mL})$ and brine $(1 \times 100$ $\mathrm{mL})$, dried $\left(\mathrm{MgSO}_{4}\right)$ and concentrated in vacuo. The resultant crude oil was purified by column chromatography (hexanes to $98: 2$ hexanes- $\mathrm{Et}_{2} \mathrm{O}$ ) to give $4.28 \mathrm{~g}$ (98\%) of disilyl ether 7 as a colorless oil: IR (film) 2957, 2934, 2891, 2860, 1652, 1471, 1254, $1081 \mathrm{~cm}^{-1}$; ${ }^{1} \mathrm{H}$ NMR $\left(500 \mathrm{MHz}, \mathrm{CDCl}_{3}\right) \delta 5.87-5.90(\mathrm{~m}, 1 \mathrm{H}), 3.91(\mathrm{t}, J=4.5 \mathrm{~Hz}, 1 \mathrm{H}), 3.70-3.74(\mathrm{~m}$, $1 \mathrm{H}), 2.52-2.61(\mathrm{~m}, 1 \mathrm{H}), 2.38(\mathrm{dt}, J=18.0,5.5 \mathrm{~Hz}, 1 \mathrm{H}), 1.91-1.97(\mathrm{~m}, 1 \mathrm{H}), 1.64-1.70$ (m, 1H), 0.88 (s, 9H), $0.08(\mathrm{~s}, 3 \mathrm{H}), 0.06(\mathrm{~s}, 3 \mathrm{H}) ;{ }^{13} \mathrm{C}$ NMR $\left(125 \mathrm{MHz}, \mathrm{CDCl}_{3}.\right) \delta 129.2$, 125.6, 72.2, 70.5, 32.1, 28.3, 25.9, 18.0, -4.6, -4.8; LRMS (CI+/ $\left./ \mathrm{NH}_{3}\right) \mathrm{m} / z$ 363.1 (M-t$\mathrm{Bu})^{+}$; HRMS $\left(\mathrm{CI}+/ \mathrm{NH}_{3}\right) \mathrm{m} / z$ calcd for $\mathrm{C}_{18} \mathrm{H}_{37} \mathrm{BrO}_{2} \mathrm{Si}_{2} 363.0811(\mathrm{M}-t-\mathrm{Bu})^{+}$; found: 363.0810 .

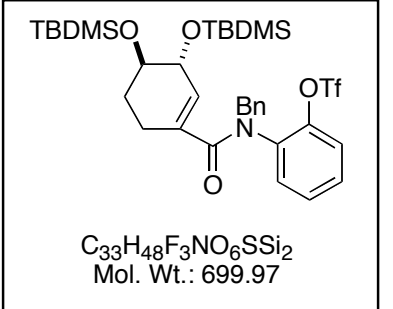

Triflate 9. tert-Butyl lithium (11.9 mL, $20.3 \mathrm{mmol}, 1.71 \mathrm{M}$ in hexanes) was added dropwise to a solution of bromide 7 (4.28 $\mathrm{g}, 10.1 \mathrm{mmol}$, previously azetropically dried from $\mathrm{PhH}$ ) in THF $(100 \mathrm{~mL})$ at $-78{ }^{\circ} \mathrm{C}$. The resulting yellow solution was maintained for 10 min before a stream of dry $\mathrm{CO}_{2}$ was bubbled into the reaction. After $5 \mathrm{~min}$ the $\mathrm{CO}_{2}$ was stopped, the cooling bath was removed, and the reaction was allowed to warm to rt. (Note: As the solution warms, a large volume of excess $\mathrm{CO}_{2}$ evolves. Use a sufficiently large flask to compensate for this out-gassing and ensure that the reaction is vented during warming.) The reaction is then quenched by the addition of $1 \mathrm{M}$ aqueous $\mathrm{HCl}(20 \mathrm{~mL})$ and brine $(10 \mathrm{~mL})$. The reaction was the extracted with EtOAc $(4 \times 100 \mathrm{~mL})$. The combined organics were dried $\left(\mathrm{MgSO}_{4}\right)$ and concentration in vacuo provided the crude acid as a colorless foam. This material was used without further purification.

The acid was then combined with $N$-benzyl-2-(trimethylsiloxy)aniline ${ }^{5}(3.34 \mathrm{~g}$, $10.7 \mathrm{mmol}$ ) and 2-chloro-1-methylpyridinium iodide (3.89 g, $15.2 \mathrm{mmol})$ were combined a in $250 \mathrm{~mL}$ flask fitted with an air condenser. The flask was then flushed with $\mathrm{N}_{2}$, and $\mathrm{PhMe}(100 \mathrm{~mL})$ and 2,4,6-collidine $(6.49 \mathrm{~g}, 7.1 \mathrm{~mL}, 50.7 \mathrm{mmol})$ were introduced successively. The resulting suspension was stirred at $80^{\circ} \mathrm{C}$ for $15 \mathrm{~h}$. The reaction mixture was cooled to rt, diluted with EtOAc $(100 \mathrm{~mL})$, and washed with $1 \mathrm{M}$ aqueous citric acid $(2 \times 100 \mathrm{~mL})$, water $(3 \times 100 \mathrm{~mL})$ and brine $(1 \times 100 \mathrm{~mL})$ The solution was dried $\left(\mathrm{MgSO}_{4}\right)$ and concentrated in vacuo to give silyl-phenol ether $\mathbf{8}$ as a crude golden-yellow oil. This compound was used without further purification or characterization.

Crude 8 was dissolved in 3:1 THF- $\mathrm{H}_{2} \mathrm{O}(120 \mathrm{~mL}) . \mathrm{K}_{2} \mathrm{CO}_{3}(10 \mathrm{~g})$ was added and the resulting biphasic solution was rapidly stirred for $1 \mathrm{hr}$. The reaction extracted EtOAc $(3 \times 100 \mathrm{~mL})$. The combined organics were washed with brine $(1 \times 100 \mathrm{~mL})$, dried

\footnotetext{
${ }^{5}$ Overman, L.E.; Watson, D. A. previous paper in this issue.
} 
$\left(\mathrm{MgSO}_{4}\right)$ and concentrated in vacuo to give the free phenol a crude brown oil. This was used without further purification or characterization.

Finally, the phenol was dissolved in DMF (100 mL). $\operatorname{PhNTf}_{2}(3.71 \mathrm{~g}, 10.4 \mathrm{mmol})$ and $\mathrm{Cs}_{2} \mathrm{CO}_{3}$ (10.0 g, $31.2 \mathrm{mmol}$ ) were added the resulting slurry was stirred for $20 \mathrm{~min}$. At that time, the reaction was diluted with EtOAc $(200 \mathrm{~mL})$ and the solution was washed with water $(3 \times 150 \mathrm{~mL})$ and brine $(1 \times 150 \mathrm{~mL})$. After drying $\left(\mathrm{MgSO}_{4}\right)$, concentration in vacuo to give a crude brown oil which was purified by column chromatography (95:5 to 92:8 hexanes- $\left.\mathrm{Et}_{2} \mathrm{O}\right)$ to give $5.37 \mathrm{~g}(76 \%$ from bromide 7$)$ of triflate 9 as a colorless oil: IR (film) 2957, 2934, 2891, 2860, 1668, 1644, 1428, 1251, 1216, $1139 \mathrm{~cm}^{-1}$; ${ }^{1} \mathrm{H}$ NMR $\left(500 \mathrm{MHz}, \mathrm{CDCl}_{3}\right.$. Note: Spectrum shows complex mixture of conformers, please see spectrum for details. Useful diagnostic peaks given.) $\delta 6.89-7.04(\mathrm{bm}), 6.88-6.94$ (bs), 5.70-5.87 (bm), 5.30-5.46 (bm), 4.07-4.24 (bm), 3.55-3.70 (bm), 2.30-2.52 (bm), 0.85 (bs), 0.78 (bs), $-0.20-0.05$ (bm); ${ }^{13} \mathrm{C}$ NMR (125 MHz, $\mathrm{CDCl}_{3}$. Note: Spectrum shows complex mixture of conformers, please see spectrum for details. Useful diagnostic peaks given.) $\delta 170.7,128.7,127.9,122.4,122.2,118.4$ (q, $J=318.5 \mathrm{~Hz}), 71.8,71.4,70.3$, 52.7, 27.6, 26.9, 25.8, 23.1, 18.0, -4.5, -4.8; LRMS (ESI) $\mathrm{m} / z$. $700.26(\mathrm{M}+\mathrm{H})^{+}, 722.22$ $(\mathrm{M}+\mathrm{Na})^{+}$; HRMS (ESI) $m / z$ calcd for $\mathrm{C}_{33} \mathrm{H}_{48} \mathrm{~F}_{3} \mathrm{NO}_{6} \mathrm{SSi}_{2} 700.2771(\mathrm{M}+\mathrm{H})^{+}$; found: 700.2778. Anal. Calcd for $\mathrm{C}_{33} \mathrm{H}_{48} \mathrm{~F}_{3} \mathrm{NO}_{6} \mathrm{SSi}_{2}: \mathrm{C}, 56.82 ; \mathrm{H}, 6.91 ; \mathrm{N}, 2.00$. Found: C, 56.76; H, 7.05; N, 2.14.

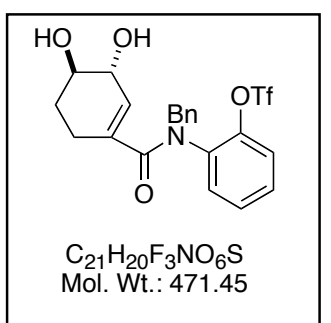

Diol 10. In a Nalgene ${ }^{\circledR}$ vial, aqueous $\mathrm{HF}(0.5 \mathrm{~mL}, 49 \%)$ was added to a solution of disilyl ether 9 (285 $\mathrm{mg}, 408 \mu \mathrm{mol})$ in $\mathrm{MeCN}(8$ $\mathrm{mL})$. The solution was maintained for $8 \mathrm{~h}$ at which time TLC analysis indicated that reaction was complete. The reaction was quenched by the addition of saturated aqueous $\mathrm{NaHCO}_{3}(10 \mathrm{~mL})$, then extracted with EtOAc $(3 \times 10 \mathrm{~mL})$. The combined organics were washed with brine $(5 \mathrm{~mL})$, dried $\left(\mathrm{MgSO}_{4}\right)$ and concentrated in vacuo to provide a crude solid. Purification of this solid by column chromatography (80:20 EtOAc-hexanes to EtOAc) provided $155 \mathrm{mg}(81 \%)$ of diol 10 as a colorless foam: IR (film) 3379 (b), 2929, 2871, 1630, 1603, 1422, 1214, $1136 \mathrm{~cm}^{-1}$; ${ }^{1} \mathrm{H}$ NMR $\left(500 \mathrm{MHz}, \mathrm{CDCl}_{3}\right.$. Note: Spectrum shows complex mixture of conformers, please see spectrum for details. Useful diagnostic peaks given.) $\delta$ 6.90-7.06 (bm), 5.78 (bs), 5.35-5.55 (bm), 4.15 (bs), 3.67-3.85 (bm), 3.41 (bs), 2.63-2.83 (bm), 1.88 (bs), 1.48 (bs); ${ }^{13} \mathrm{C}$ NMR $\left(125 \mathrm{MHz}, \mathrm{CDCl}_{3}\right.$. Note: Spectrum shows complex mixture of conformers, please see spectrum for details. Useful diagnostic peaks given.) $\delta 170.4$, 144.3, 130.2, 122.2, 118.4 (q, $J=318.8 \mathrm{~Hz}$ ), 72.8, 72.5, 72.3, 72.2, 52.8, 28.0, 25.5, 24.9; LRMS (ESI) $m / z 472.14(\mathrm{M}+\mathrm{H})^{+}, 494.12(\mathrm{M}+\mathrm{Na})^{+}$; HRMS $\left(\mathrm{CI}+\mathrm{NH}_{3}\right) \mathrm{m} / z$ calcd for $\mathrm{C}_{21} \mathrm{H}_{20} \mathrm{~F}_{3} \mathrm{NO}_{6} \mathrm{~S} 471.0963(\mathrm{M}+\mathrm{H})^{+}$; found: 471.0964. Anal. Calcd for $\mathrm{C}_{21} \mathrm{H}_{20} \mathrm{~F}_{3} \mathrm{NO}_{6} \mathrm{~S}$ : $\mathrm{C}$, 53.50; H, 4.28; N, 2.97. Found: C 53.28; H, 4.43; N, 2.85. 


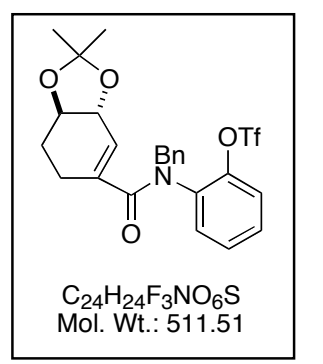

Acetonide 11. Diol 10 (163 mg, $345 \mu \mathrm{mol})$, 2,2-dimethoxypropane (39.5 mg, $379 \mu \mathrm{mol}, 47 \mu \mathrm{L}$, freshly distilled), PPTS (8.6 mg, 34.5 $\mu \mathrm{mol}), 4 \AA$ molecular sieves (1.6 g, activated beads, Linde type) and benzene $(3.5 \mathrm{~mL})$ were combined in a glass reaction tube designed for high pressure applications. Behind a blast shield, the reaction was heated to $80{ }^{\circ} \mathrm{C}$ for $12 \mathrm{~h}$. After that time, the reaction was cooled to room temperature and filter through a short $(\mathrm{ca} .1 \mathrm{~cm})$ plug of basic aluminum oxide washing with $\mathrm{Et}_{2} \mathrm{O}$. The filtrate was concentrated in vacuo and the residue was purified by column chromatography (50-200 $\mu \mathrm{m}$ mess basic aluminum oxide stationary phase, $\mathrm{Et}_{2} \mathrm{O}$ as eluent) to give $74.1 \mathrm{mg}(42 \%)$ of acetonide $\mathbf{1 1}$ as a colorless foam: IR (film) 3038, 2988, 2937, 2883, 1660, 1494, 1424, 1212, $1139 \mathrm{~cm}^{-}$ '; ${ }^{1} \mathrm{H}$ NMR (500 MHz, $\mathrm{CDCl}_{3}$. Note: Spectrum shows complex mixture of conformers, please see spectrum for details. Useful diagnostic peaks given.) $\delta$ 7.00-7.10 (bm), 6.88 (bd, $J=8.1 \mathrm{~Hz}$ ), 6.66 (bs), 6.50 (bs), 5.89 (bs), 4.10 (bs), 3.73 (bs), 3.39 (bs), 1.82-1.88 (m), 1.27 (bs); ${ }^{13} \mathrm{C}$ NMR $\left(125 \mathrm{MHz}, \mathrm{CDCl}_{3}\right.$. Note: Spectrum shows complex mixture of conformers, please see spectrum for details. Useful diagnostic peaks given.) $\delta 169.8$, $145.1,138.5,135.1,122.5,116.8$ (q, $J=318.6 \mathrm{~Hz}), 111.6,78.0,53.6,27.2,24.2$; LRMS $\left(\mathrm{CI}+/ \mathrm{NH}_{3}\right) \mathrm{m} / z 511.2(\mathrm{M})^{+}$; HRMS $\left(\mathrm{CI}+/ \mathrm{NH}_{3}\right) \mathrm{m} / z$ calcd for $\mathrm{C}_{24} \mathrm{H}_{24} \mathrm{~F}_{3} \mathrm{NO}_{6} \mathrm{~S} 511.1276(\mathrm{M})^{+}$; found: 511.1279 .

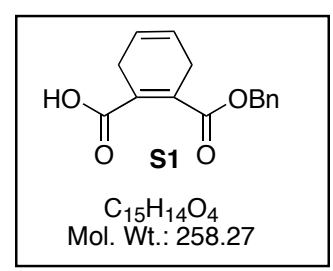

Acid S1. A solution of LiHMDS (112 mmol, $86.0 \mathrm{~mL}, 1.3 \mathrm{M}$ in THF) was added dropwise to a stirred solution of benzyl alcohol $(13.8 \mathrm{~g}, 13.2 \mathrm{~mL}, 128 \mathrm{mmol})$ in THF $(100 \mathrm{~mL})$ at $0{ }^{\circ} \mathrm{C}$. The resulting red colored solution was maintained for $30 \mathrm{~min}$ at $0{ }^{\circ} \mathrm{C}$. In a separate flask, a solution of 1,2-dicarboxyacid-1,4-cyclohexadiene anhydride $^{6}$ (16.0 g, $106 \mathrm{mmol}$ ) in THF (400 mL) was cooled to -78 ${ }^{\circ} \mathrm{C}$ to give a white suspension. The alkoxide solution was added to this suspension dropwise via a cannula to give a red homogenous solution. This solution was maintained for $10 \mathrm{~min}$ at $-78{ }^{\circ} \mathrm{C}$. Then the still cold solution was quenched by the successive addition of $1 \mathrm{~N} \mathrm{HCl}(200 \mathrm{~mL})$ and $\mathrm{Et}_{2} \mathrm{O}(400 \mathrm{~mL})$. The reaction was warmed to room temperature, the phases were separated, and the organic layer was washed with $\mathrm{H}_{2} \mathrm{O}(2 \times 400 \mathrm{~mL})$ and brine $(1 \times 400 \mathrm{~mL})$, dried over $\mathrm{MgSO}_{4}$ and concentrated in vacuo. Recrystallization of the resulting solid (hot hexanes-EtOAc) gave $20.5 \mathrm{~g}(75 \%)$ of acid S1 as white needles: mp $114-115^{\circ} \mathrm{C}$ (hexanes-EtOAc); IR (film) 3038(b), 2527, 1719, 1690, $1274 \mathrm{~cm}^{-1} ;{ }^{1} \mathrm{H}$ NMR (500 MHz, $\mathrm{CDCl}_{3}$ ) $\delta$ 7.36-7.29 (m, 5H), 5.76-5.68 (m, 2H), $5.20(\mathrm{~s}, 2 \mathrm{H}), 3.10-2.92(\mathrm{~m}, 4 \mathrm{H}) ;{ }^{13} \mathrm{C}$ NMR $\left(125 \mathrm{MHz}, \mathrm{CDCl}_{3}\right) \delta 172.2$ (b), 168.3, 136.6, 135.2, 129.3, 128.6, 128.44, 128.38, 122.7, 121.9, 67.3, 28.3, 26.8; LRMS (ESI) $\mathrm{m} / \mathrm{z}$ $281.06(\mathrm{M}+\mathrm{Na})^{+}, 303.06(\mathrm{M}-\mathrm{H}+2 \mathrm{Na})^{+}$. Anal. Calcd for $\mathrm{C}_{15} \mathrm{H}_{14} \mathrm{O}_{4}: \mathrm{C}, 69.76 ; \mathrm{H}, 5.46$. Found: C, 69.63; H, 5.45 .

\footnotetext{
${ }^{6}$ Maier, G.; Sayrac, T.; Reisenauer, H. P. Chem. Ber. 1982, 115, 2202-2213.
} 


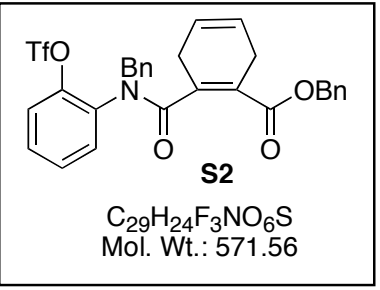

Triflate S2. Oxalyl chloride $(7.11 \mathrm{~mL}, 81.3 \mathrm{mmol})$ was added dropwise to a solution of acid S1 (20.0 g, $77.4 \mathrm{mmol}), 2,6-$ lutidine $(41.5 \mathrm{~g}, 45.0 \mathrm{~mL}, 387 \mathrm{mmol})$ and DMF $(0.7 \mathrm{~mL})$ in $\mathrm{CH}_{2} \mathrm{Cl}_{2}(800 \mathrm{~mL})$ in a flask fitted with a vent needle at $-10{ }^{\circ} \mathrm{C}$. Once gas evolution ceased, the resulting yellow solution was added via cannula to a stirred solution of $N$-benzyl-2(trimethylsiloxy)aniline $(25.4 \mathrm{~g}, 81.3 \mathrm{mmol})$ in $\mathrm{Et}_{2} \mathrm{O}(2 \mathrm{~L})$ at -10

${ }^{\circ} \mathrm{C}$ to give a brown colored suspension. The reaction was then poured in to $1 \mathrm{M}$ aqueous citric acid solution ( $2 \mathrm{~L})$, and the layers were separated. The organic phase was then washed with $\mathrm{H}_{2} \mathrm{O}(2 \times 2 \mathrm{~L})$ and brine $(1 \times 2 \mathrm{~L})$, dried over $\mathrm{MgSO}_{4}$ and concentrated in vacuo to give a crude orange solid. This material was used without further purification.

The crude solid was then dissolved in DMF $(600 \mathrm{~mL})$, and the solution was sparged with Ar for 15 min. Solid CsF (23.4 g, $154 \mathrm{mmol})$ and $\operatorname{PhNTf}_{2}$ (32.8 g, 100 $\mathrm{mmol}$ ) were then added in a single portion and the resulting suspension was stirred for 1 h. The reaction was then diluted with $\mathrm{Et}_{2} \mathrm{O}(600 \mathrm{~mL})$ and washed with $\mathrm{H}_{2} \mathrm{O}(2 \times 2 \mathrm{~L})$ and brine $(1 \times 2 \mathrm{~L})$. The organic phase was then dried of $\mathrm{MgSO}_{4}$ and concentrated in vacuo to give a crude yellow solid. Recrystallization from EtOAc/Hexanes gave $23.8 \mathrm{~g}$ (54\% yield, over two steps) of triflate S2: mp 110-112 ${ }^{\circ} \mathrm{C}$ (hexanes/EtOAc); IR (film) 3035, 1715, 1160, 1425, $1221 \mathrm{~cm}^{-1}$; ${ }^{1} \mathrm{H}$ NMR $\left(500 \mathrm{MHz}, \mathrm{CDCl}_{3}\right.$. Note: Spectrum shows mixture of conformers, please see spectrum for details. Useful diagnostic peaks given.) $\delta$ 7.36-7.13 (m), 7.07-7.00 (m), 6.90-6.85 (m), 6.84-6.76 (m), 5.80-5.70 (m), 5.55-5.45 (m), 5.17-5.12 (m), 5.02-4.95 (m), 4.74 (bs), 4.18-4.12 (ad), 3.02 (s, 4H); ${ }^{13} \mathrm{C}$ NMR (125 $\mathrm{MHz}, \mathrm{CDCl}_{3}$. Note: Spectrum shows mixture of conformers, major peaks are given.) $\delta 171.4,170.7,165.6,165.3,145.9,144.8,142.8,135.9,135.8,135.6,134.8,132.8$, $132.6,132.3,131.3,129.9,129.8,129.0,128.9,128.6,128.5,128.47,128.45,128.32$, $128.26,128.25,128.22,128.0,127.9,127.6,125.6,124.6,123.5,123.0,121.6,121.5$, $121.3,121.9,118.4(\mathrm{ad}, J=318.1 \mathrm{~Hz}), 118.3(\mathrm{ad}, J=318.4 \mathrm{~Hz}), 66.8,66.5,54.2,51.2$, 29.8, 29.0, 26.1; LRMS (ESI) $\mathrm{m} / z 571.99(\mathrm{M}+\mathrm{H})^{+}, 593.90(\mathrm{M}+\mathrm{Na})^{+}$. Anal. Calcd for $\mathrm{C}_{29} \mathrm{H}_{24} \mathrm{~F}_{3} \mathrm{NO}_{6} \mathrm{~S}: \mathrm{C}, 60.94 ; \mathrm{H}, 4.23 ; \mathrm{N}, 2.45$. Found: C, 60.85; H, 4.24; N, 2.41.

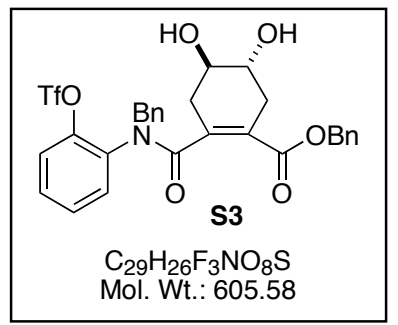

Diol S3. Triflate S2 (8.25 $\mathrm{g}, 14.4 \mathrm{mmol})$ was dissolved in $\mathrm{CH}_{2} \mathrm{Cl}_{2}(400 \mathrm{~mL})$ and cooled to $0{ }^{\circ} \mathrm{C}$ in an ice bath. $m$-CPBA (10.2 g, ca. 57.7 mmol; $70 \%$ technical grade) was then added in one portion and the cooling bath was removed. The resulting reaction was maintained at room temperature for $3.5 \mathrm{~h}$ during which time the solution became cloudy. The reaction was then quenched by the addition of $1 \mathrm{M} \mathrm{Na}_{2} \mathrm{~S}_{2} \mathrm{O}_{3}(400 \mathrm{~mL})$, and the resulting biphasic solution was rapidly stirred for $30 \mathrm{~min}$. The mixture was then diluted with $\mathrm{Et}_{2} \mathrm{O}(400 \mathrm{~mL})$, and the layers were separated. The organic phase was washed with $1 \mathrm{M}$ aqueous $\mathrm{NaOH}(1 \times 400 \mathrm{~mL})$, water $(2 \times 400 \mathrm{~mL})$ and brine $(1 \times 400 \mathrm{~mL})$. Drying $\left(\mathrm{MgSO}_{4}\right)$ and concentration in vacuo of the resulting solution then provided the crude epoxide as a colorless foam which was used without further purification.

The crude epoxide was then dissolved in 3:1 THF- $\mathrm{H}_{2} \mathrm{O}(200 \mathrm{~mL})$. Trifluoroacetic acid $(0.5 \mathrm{~mL})$ was then added and the resulting solution was heated to $80{ }^{\circ} \mathrm{C}$ under a reflux condenser for $12 \mathrm{~h}$. The reaction was then cooled to room temperature and diluted 
with EtOAc $(200 \mathrm{~mL})$. The layers were then separated, and the organic phase was washed with saturated aqueous $\mathrm{NaHCO}_{3}(1 \times 200 \mathrm{~mL}), \mathrm{H}_{2} \mathrm{O}(1 \times 200 \mathrm{~mL})$ and brine $(1 \times 200$ $\mathrm{mL})$. Drying $\left(\mathrm{MgSO}_{4}\right)$ and concentration in vacuo provided a crude oil. Purification by column chromatography (40:60 hexanes-EtOAc) provided $7.00 \mathrm{~g}(80 \%$, two steps) of diol S3 as a colorless oil: IR (film) 3405 (b), 3038, 2910, 1714, 1633, 1420, 1212, 728 $\mathrm{cm}^{-1}$; ${ }^{1} \mathrm{H}$ NMR $\left(500 \mathrm{MHz}, \mathrm{CDCl}_{3}\right.$. Note: Spectrum shows mixture of conformers, please see spectrum for details. Useful diagnostic peaks given.) $\delta$ 7.15-7.38 (m), 7.03-7.15 (m), 6.67-6.82 (m), 5.78 (add), 4.99 (ad), 4.72 (bs), 4.14 (add), 3.83 (bs), 3.56-3.58 (m), 3.18-3.20 (m): ${ }^{13} \mathrm{C} \mathrm{NMR}\left(125 \mathrm{MHz}, \mathrm{CDCl}_{3}\right.$. Note: Spectrum shows mixture of conformers, major peaks are given.) $\delta 171.0,169.9,164.9,118.4$ (q, $J=318.8 \mathrm{~Hz}), 69.9$, 69.7, 69.4, 54.4, 51.2, 35.0, 34.6, 32.3, 32.0; LRMS (ESI) $m / z 606.28(\mathrm{M}+\mathrm{H})^{+}, 628.25$ $(\mathrm{M}+\mathrm{Na})^{+}$; HRMS (ESI) Calcd for $\mathrm{C}_{29} \mathrm{H}_{26} \mathrm{~F}_{3} \mathrm{NO}_{8} \mathrm{~S} \mathrm{~m} / \mathrm{z} 628.1229(\mathrm{M}+\mathrm{Na})^{+}$; Found 628.1243. Anal. Calcd for $\mathrm{C}_{29} \mathrm{H}_{26} \mathrm{~F}_{3} \mathrm{NO}_{8} \mathrm{~S}$ : C, 57.52; H, 4.33; N, 2.31. Found: C, 57.30; H, $4.51 ; \mathrm{N}, 2.23$.

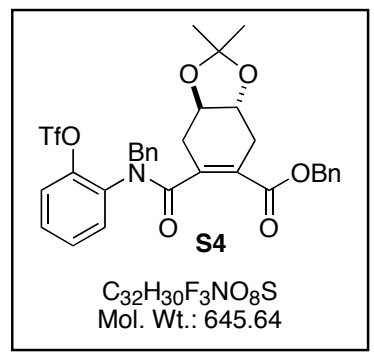

Acetonide S4. Camphorsulfonic acid (269 mg, $1.16 \mathrm{mmol})$ was added to a stirred solution of diol $\mathbf{S 3}(7.0 \mathrm{~g}, 11.6 \mathrm{mmol})$ in $1: 1$ acetone-2,2-dimethoxypropane $(220 \mathrm{~mL})$. The resulting solution was maintained for $4 \mathrm{~h}$ at room temperature and then quenched by the addition of solid $\mathrm{NaHCO}_{3}(1 \mathrm{~g})$. The resulting suspension was filtered, and the solids were washed with acetone. Concentration of the filtrate in vacuo gave a crude oil, which was purified by column chromatography ( $80: 20$ hexanes-EtOAc) to give $6.20 \mathrm{~g}$ (83\%) of acetonide $\mathbf{S 4}$ as a colorless foam: IR (film) 2987, 1718, 1660, 1421, $1223 \mathrm{~cm}^{-1}$; ${ }^{1} \mathrm{H}$ NMR $\left(500 \mathrm{MHz}, \mathrm{CDCl}_{3}\right.$. Note: Spectrum shows mixture of conformers, please see spectrum for details. Useful diagnostic peaks given.) $\delta$ 7.20-7.45 (m), 7.08$7.17(\mathrm{~m}), 6.85-6.93(\mathrm{~m}), 6.84(\mathrm{ad}), 5.18-5.23(\mathrm{~m}), 5.06(\mathrm{ad}), 4.30-4.90(\mathrm{~b}), 4.19-4.25$ (m), 3.74 (bs), 3.49-3.58 (m), 1.52 (s), 1.42 (s), 1.37-1.38 (m); ${ }^{13} \mathrm{C}$ NMR (125 MHz, $\mathrm{CDCl}_{3}$. Note: Spectrum shows mixture of conformers, major peaks are given.) $\delta 170.5,169.7,169.4,165.0,164.8,145.8,144.9,144.8,143.6,143.1,131.0,130.2$, 129.2, 129.0, 128.46, $118.4(\mathrm{q}, J=318.0 \mathrm{~Hz}), 118.3(\mathrm{q}, J=318.5 \mathrm{~Hz}), 67.2$, 66.9, 66.8, 54.4, 51.3, 33.5, 33.0, 32.9, 30.8, 30.4, 27.0, 26.9; LRMS (ESI) $\mathrm{m} / z 668.07(\mathrm{M}+\mathrm{Na})^{+}$. Anal. Calcd for $\mathrm{C}_{32} \mathrm{H}_{30} \mathrm{~F}_{3} \mathrm{NO}_{6} \mathrm{~S}$ : C, 59.53; H, 4.68; N, 2.17. Found: C, 59.68; H, 4.83; N, 2.07 . 


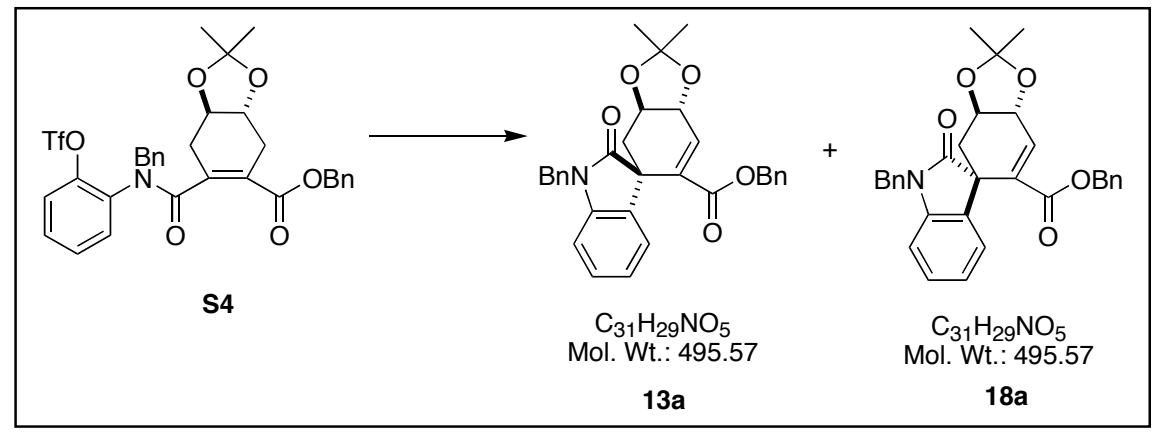

Preparation of 13a and $18 \mathrm{a}^{7} \mathrm{~A}$ base-washed, glass reactor equipped with a sealable Teflon-stopcock and a magnetic stir bar was charged with triflate $\mathbf{S 4}$ (3.00 g, 4.64 mmol), $\mathrm{Pd}\left(\mathrm{PPh}_{3}\right)_{2} \mathrm{Cl}_{2}(652 \mathrm{mg}, 929 \mu \mathrm{mol}), \mathrm{Bu}_{3} \mathrm{~N}(8.61 \mathrm{~g}, 11.2 \mathrm{~mL}, 46.4 \mathrm{mmol})$ and DMA (47 $\mathrm{mL})$. The reactor was then quickly degassed using freeze-pump-thaw technique, sealed under vacuum and placed in a $120{ }^{\circ} \mathrm{C}$ oil bath. The reaction was maintained with stirring for 165 min during which time the initial yellow suspension became a deep red, homogenous solution. The reaction was then cooled to room temperature, opened to the atmosphere and diluted with $\mathrm{Et}_{2} \mathrm{O}(150 \mathrm{~mL})$. The resultant solution was washed with water $(2 \times 150 \mathrm{~mL})$ and brine $(1 \times 150 \mathrm{~mL})$, dried over $\mathrm{MgSO}_{4}$ and concentrated in vacuo. ${ }^{1} \mathrm{H}$ NMR analysis of the crude reaction mixture showed a 75:25 mixture of diastereomers 13a and 18a. Column chromatography (85:14.5:0.5 hexanes-EtOAc-Et $\left.{ }_{3} \mathrm{~N}\right)$ allowed for partial separation of these isomers affording a total of $1.67 \mathrm{~g}(73 \%)$ of $\mathbf{1 3 a}$ and 18a. These isomers could be further separated by MPLC (92:7.5:0.5 hexanesEtOAc-Et ${ }_{3} \mathrm{~N}$ ). Slow diffusion of $n$-pentane into a solution of 13a in EtOAc provided crystals (needles) suitable for X-ray diffraction analysis and allowed for the assignment of stereochemistry of these compounds.

Data for 13a: $\mathrm{mp}=127-128^{\circ} \mathrm{C}$ (EtOAc-n-pentane); IR (film) $2985,1715,1610$, 1228, $1070 \mathrm{~cm}^{-1} ;{ }^{1} \mathrm{H}$ NMR $\left(500 \mathrm{MHz}, \mathrm{C}_{6} \mathrm{D}_{6}\right) \delta 7.00(\mathrm{~d}, J=1.7 \mathrm{~Hz}, 1 \mathrm{H}), 7.24-7.26(\mathrm{~m}$, 2H), 7.07-7.10 (m, 2H), 6.94-7.02 (m, 4H), $6.89(\mathrm{dt}, J=7.7,1.2 \mathrm{~Hz}, 1 \mathrm{H}), 6.75(\mathrm{~m}, 3 \mathrm{H})$, $6.63(\mathrm{dt}, J=7.6,0.9 \mathrm{~Hz}, 1 \mathrm{H}), 6.41(\mathrm{~d}, J=7.7 \mathrm{~Hz}, 1 \mathrm{H}), 4.83(\mathrm{~d}, J=15.9 \mathrm{~Hz}, 1 \mathrm{H}), 4.67(\mathrm{~d}$, $J=12.2 \mathrm{~Hz}, 1 \mathrm{H}), 4.56(\mathrm{~d}, J=12.2 \mathrm{~Hz}, 1 \mathrm{H}), 4.39(\mathrm{~d}, J=15.9 \mathrm{~Hz}, 1 \mathrm{H}), 4.28(\mathrm{dd}, J=8.5$, $1.7 \mathrm{~Hz}, 1 \mathrm{H}), 4.05-4.10(\mathrm{~m}, 1 \mathrm{H}), 2.64(\mathrm{t}, J=11.8 \mathrm{~Hz}, 1 \mathrm{H}), 2.08(\mathrm{dd}, J=11.7,3.6 \mathrm{~Hz}$, $1 \mathrm{H}), 1.44(\mathrm{~s}, 3 \mathrm{H}), 1.34(\mathrm{~s}, 3 \mathrm{H}) ;{ }^{13} \mathrm{C}$ NMR $\left(125 \mathrm{MHz}, \mathrm{C}_{6} \mathrm{D}_{\mathrm{c}}\right) \delta$ 178.7, 164.2, 143.4, 141.8, $137.1136 .2,135.7,131.7,129.3,128.91,128.88,128.7,128.5,128.0,122.9,122.7$, 112.6, 110.0, 78.6, 74.9, 67.2, 54.0, 44.4, 38.6, 27.3, 27.1; LRMS (ESI) $\mathrm{m} / z$ 496.20 $(\mathrm{M}+\mathrm{H})^{+}, 518.17(\mathrm{M}+\mathrm{Na})^{+}$; HRMS (ESI) Calcd for $\mathrm{C}_{31} \mathrm{H}_{29} \mathrm{NO}_{5} \mathrm{~m} / z, 518.1943(\mathrm{M}+\mathrm{Na})^{+}$; found: 518.1945. Anal Calc for $\mathrm{C}_{31} \mathrm{H}_{29} \mathrm{NO}_{5} \mathrm{C}, 75.13 ; \mathrm{H}, 5.90 ; \mathrm{N}, 2.83$. Found: C, 74.84; H, 5.92; N, 2.92.

Data for 18a: IR (film) 2985, 1714, 1613, 1229, $1067 \mathrm{~cm}^{-1} ;{ }^{1} \mathrm{H}$ NMR (500 MHz, $\left.\mathrm{C}_{6} \mathrm{D}_{6}\right) \delta 7.73(\mathrm{~d}, J=1.7 \mathrm{~Hz}, 1 \mathrm{H}), 7.20-7.25(\mathrm{~m}, 2 \mathrm{H}), 7.11-7.14(\mathrm{bs}, 2 \mathrm{H}), 7.01-7.06(\mathrm{~m}$, 2H), 6.92-6.99 (m, 4H), $6.84(\mathrm{dt}, J=7.7,1.3 \mathrm{~Hz}, 1 \mathrm{H}), 6.71-6.76(\mathrm{~m}, 3 \mathrm{H}), 6.66$ (d, $J=$

7 This reaction was preformed using Schlenk-line techniques. The conditions were optimized to maximize the production of minor product 18a and minimize production side-products resulting from alkene migration. 
$7.2 \mathrm{~Hz}, 1 \mathrm{H}), 6.39(\mathrm{~d}, J=7.7 \mathrm{~Hz}, 1 \mathrm{H}), 4.84(\mathrm{~d}, J=15.8 \mathrm{~Hz}, 1 \mathrm{H}), 4.76(\mathrm{~m}, 1 \mathrm{H}), 4.63(\mathrm{~d}, J$ $=12.3 \mathrm{~Hz}, 1 \mathrm{H}), 4.54(\mathrm{~d}, J=12.3 \mathrm{~Hz}, 1 \mathrm{H}), 4.32(\mathrm{~d}, J=15.8 \mathrm{~Hz}, 1 \mathrm{H}), 4.17(\mathrm{dd}, J=8.4$, $1.7 \mathrm{~Hz}, 1 \mathrm{H}), 2.49(\mathrm{dd}, J=12.7,3.8 \mathrm{~Hz}, 1 \mathrm{H}), 1.92(\mathrm{t}, J=12.7 \mathrm{~Hz}, 1 \mathrm{H}), 1.39$ (s, 3H), 1.36 $(\mathrm{s}, 3 \mathrm{H}) ;{ }^{13} \mathrm{C}$ NMR $\left(125 \mathrm{MHz}, \mathrm{C}_{6} \mathrm{D}_{\mathrm{c}}\right) \delta 178.8,164.6,143.9,142.4,137.2,136.2,134.6$, 131.9, 129.3, 128.9, 128.8, 128.7. 128.1, 128.0, 123.0, 122.9, 112.6, 109.9, 78.7, 74.5, 67.2, 53.1, 44.4, 38.0, 27.4, 27.1; LRMS (ESI) $\mathrm{m} / \mathrm{z} 496.19(\mathrm{M}+\mathrm{H})^{+}, 518.16(\mathrm{M}+\mathrm{Na})^{+}$; HRMS (ESI) Calcd for $\mathrm{C}_{31} \mathrm{H}_{29} \mathrm{NO}_{5} \mathrm{~m} / z$ 518.1955 (M+Na) ${ }^{+}$; found: 518.1945.

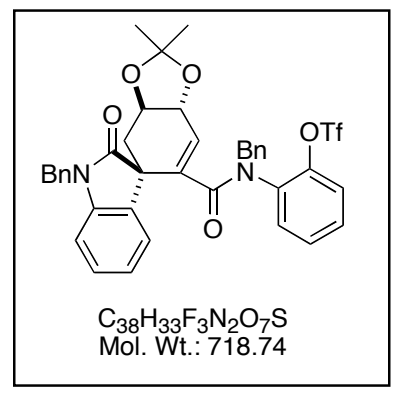

Acetonide 17a. A solution of benzyl ester 13a (347 mg, 700 $\mu \mathrm{mol})$ in EtOAc $(16 \mathrm{~mL})$ was placed under a atmosphere of $\mathrm{N}_{2}$. $\mathrm{Pd} / \mathrm{C}$ (170 mg, 10\% wt, $50 \%$ water Degaussa Type) was added and the atmosphere was replaced with $\mathrm{H}_{2}$ (balloon). The reaction was rapidly stirred for $1 \mathrm{~h}$, at which time TLC analysis indicated complete ester cleavage. The flask was vented and the reaction was filtered through a plug of Celite ${ }^{\circledR}$, washing with EtOAc. Two drops of 2,6-lutidine were added to the filtrate, which was then concentrated in vacuo. The resulting crude acid 14a was then azetropically dried from benzene twice before being dried under vacuum ( $c a$. 0.05 $\mathrm{mmHg}$ ) for $2 \mathrm{~h}$. This material was used without further purification.

Crude acid 14a was then dissolved in $\mathrm{CH}_{2} \mathrm{Cl}_{2}(7 \mathrm{~mL})$ containing 1 drop of DMF. Oxalyl chloride $(97.7 \mathrm{mg}, 67 \mu \mathrm{L}, 770 \mu \mathrm{mol})$ was added dropwise at room temperature. Once gas evolution has ceased, the resulting solution was added via cannula addition of a stirred solution of $\mathrm{N}$-benzyl-2-(tert-butyldimethylsiloxy)aniline ${ }^{5}$ (15) (438 mg, 1.40 $\mathrm{mmol})$ and 2,6-lutidine $(0.24 \mathrm{~mL}, 2.10 \mathrm{mmol})$ in $\mathrm{Et}_{2} \mathrm{O}(30 \mathrm{~mL})$ to give a colorless suspension. After $1 \mathrm{~h}$, the reaction was quenched by pouring into a solution of saturated aqueous $\mathrm{NaHCO}_{3}$ (ca. $30 \mathrm{~mL}$ ). The layers were separated and the organic phase was washed with $1 \mathrm{M}$ aqueous citric acid $(10 \mathrm{~mL})$, saturated aqueous $\mathrm{NaHCO}_{3}(2 \times 30 \mathrm{~mL})$, water $(30 \mathrm{~mL})$ and brine $(30 \mathrm{~mL})$. Drying $\left(\mathrm{MgSO}_{4}\right)$ and concentration in vacuo gave crude 16a as a yellow oil. The material was partially purified by rapid column chromatography $\left(84.5: 15.0: 0.5\right.$ hexanes-EtOAc-Et $\left.{ }_{3} \mathrm{~N}\right)$ to give $239 \mathrm{mg}$ of semi-pure siloxy phenol 16a which was used with further purification.

The siloxy phenol 16a (239 mg, ca. $349 \mu \mathrm{mol}$ ) was then disolved in DMF (3 mL) and the resulting solution was sparged with a dry steam of Ar for $5 \mathrm{~min} . \mathrm{Cs}_{2} \mathrm{CO}_{3}(555 \mathrm{mg}$, $1.70 \mathrm{mmol}$ ), CsF (257 mg, $1.70 \mathrm{mmol}$ ) and $\mathrm{PhNTf}_{2}$ (365 mg, $1.02 \mathrm{mmol}$ ) were added sequentially and the resulting suppension was rapidly stirred for $1 \mathrm{~h}$. At that time, TLC analysis indicated that the reaction was complete. The reaction was diluted with EtOAc $(30 \mathrm{~mL})$ and washed with water $(2 \times 15 \mathrm{~mL})$ and brine $(15 \mathrm{~mL})$. The resulting solution was dried $\left(\mathrm{MgSO}_{4}\right)$ and concentration in vacuo gave a crude, yellow oil. Purification of this oil by column chromatography (79.5:20.0:0.5 hexanes-EtOAc-Et $\left.{ }_{3} \mathrm{~N}\right)$ gave $142 \mathrm{mg}$ (31\% from ester 13a) of acetonide 17b as a colorless foam: IR (film) 3038, 2988, 1718, 1656, 1220, $1139 \mathrm{~cm}^{-1}$; ${ }^{1} \mathrm{H}$ NMR $\left(500 \mathrm{MHz}, \mathrm{CDCl}_{3}\right.$. Note: Spectrum shows complex mixture of conformers, please see spectrum for details. Useful diagnostic peaks given.)

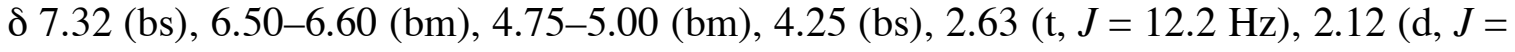
$11.6 \mathrm{~Hz}), 1.23(\mathrm{~s}) ;{ }^{13} \mathrm{C} \mathrm{NMR}\left(125 \mathrm{MHz}, \mathrm{CDCl}_{3}\right.$. Note: Spectrum shows complex mixture of conformers, please see spectrum for details. Useful diagnostic peaks given.) $\delta 178.7$, $170.8,119.3$ (q, $J=318.8 \mathrm{~Hz}), 112.6,110.3$, 78.6, 77.8, 76.0, 74.4, 52.9, 44.6, 27.3, 27.0; 
LRMS (ESI) $m / z 719.15(\mathrm{M}+\mathrm{H})^{+}, 736.17\left(\mathrm{M}+\mathrm{NH}_{4}\right)^{+}, 741.13(\mathrm{M}+\mathrm{Na})^{+} ; \mathrm{HRMS}(\mathrm{ESI}) \mathrm{m} / z$ calcd for $\mathrm{C}_{38} \mathrm{H}_{33} \mathrm{~F}_{3} \mathrm{~N}_{2} \mathrm{O}_{7} \mathrm{~S} 719.2039(\mathrm{M}+\mathrm{Na})^{+}$; found: 719.2014 .

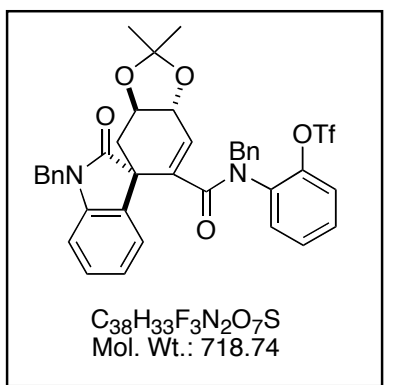

Acetonide 21a. A solution of benzyl ester 18a (315 mg, 636 $\mu \mathrm{mol})$ in EtOAc $(15 \mathrm{~mL})$ was placed under a atmosphere of $\mathrm{N}_{2}$. $\mathrm{Pd} / \mathrm{C}$ (160 mg, 10\% wt, $50 \%$ water Degaussa Type) was added and the atmosphere was replaced with $\mathrm{H}_{2}$ (balloon). The reaction was rapidly stirred for $1 \mathrm{~h}$, at which time TLC analysis indicated complete ester cleavage. The flask was vented and the reaction was filtered through a plug of Celite ${ }^{\circledR}$, washing with EtOAc. Two drops of 2,6-lutidine were added to the filtrate, which was then concentrated in vacuo. The resulting crude acid 19a was then azetropically dried from benzene twice before being dried under vacuum (ca. $0.05 \mathrm{mmHg}$ ) for $2 \mathrm{~h}$. This material was used without further purification.

Crude acid 19a was then dissolved in $\mathrm{CH}_{2} \mathrm{Cl}_{2}(7 \mathrm{~mL})$ containing 1 drop of DMF. Oxalyl chloride $(88.8 \mathrm{mg}, 61 \mu \mathrm{L}, 700 \mu \mathrm{mol})$ was added dropwise at room temperature. Once gas evolution has ceased, the resulting solution was added via cannula addition of a stirred solution of aniline $15(398 \mathrm{mg}, 1.27 \mathrm{mmol})$ and 2,6-lutidine (205 mg, $0.22 \mathrm{~mL}$, $1.91 \mathrm{mmol})$ in $\mathrm{Et}_{2} \mathrm{O}(30 \mathrm{~mL})$ to give a colorless suspension. After $1 \mathrm{~h}$, the reaction was quenched by pouring into a solution of saturated aqueous $\mathrm{NaHCO}_{3}$ (ca. $30 \mathrm{~mL}$ ). The layers were separated and the organic phase was washed with $1 \mathrm{M}$ aqueous citric acid (10 $\mathrm{mL})$, saturated aqueous $\mathrm{NaHCO}_{3}(2 \times 30 \mathrm{~mL})$, water $(30 \mathrm{~mL})$, and brine $(30 \mathrm{~mL})$. Drying $\left(\mathrm{MgSO}_{4}\right)$ and concentration in vacuo gave a crude yellow oil. The material was partially purified by rapid column chromatography (84.5:15.0:0.5 hexanes-EtOAc- $\left.\mathrm{Et}_{3} \mathrm{~N}\right)$ to give $228 \mathrm{mg}$ of semi-pure siloxy phenol 20a which was used with further purification.

The siloxy phenol 20a (228 mg, ca. $325 \mu \mathrm{mol}$ ) was then dissolved in DMF (3 $\mathrm{mL})$ and the resulting solution was sparged with a dry steam of Ar for 5 min. $\mathrm{Cs}_{2} \mathrm{CO}_{3}$ (530 mg, $1.63 \mathrm{mmol}$ ), CsF (246 mg, $1.63 \mathrm{mmol}$ ) and PhNTf $_{2}$ (348 mg, $976 \mu \mathrm{mol}$ ) were added sequentially and the resulting suppension was rapidly stirred for $1 \mathrm{~h}$. At that time, TLC analysis indicated that the reaction was complete. The reaction was diluted with EtOAc $(30 \mathrm{~mL})$ and washed with water $(2 \times 15 \mathrm{~mL})$ and brine $(15 \mathrm{~mL})$. The resulting solution was dried $\left(\mathrm{MgSO}_{4}\right)$ and concentration in vacuo gave a crude, yellow oil. Purification of this oil by column chromatography (79.5:20.0:0.5 hexanes-EtOAc-Et $\left.{ }_{3} \mathrm{~N}\right)$ gave $185 \mathrm{mg}$ (40\% from ester 18a) of acetonide 21a as a colorless foam: IR (film) 3034, 2988, 1714, 1652, $1220 \mathrm{~cm}^{-1}$; ${ }^{1} \mathrm{H}$ NMR $\left(500 \mathrm{MHz}, \mathrm{CDCl}_{3}\right.$. Note: Spectrum shows complex mixture of conformers, please see spectrum for details. Useful diagnostic peaks given.) $\delta 7.32$ (bs), 6.45-6.70 (bm), 5.83 (bs), 4.70-5.10 (bm), 2.52 (bs), 1.94 (bs), 1.30 (s); ${ }^{13} \mathrm{C} \mathrm{NMR}\left(125 \mathrm{MHz}, \mathrm{CDCl}_{3}\right.$. Note: Spectrum shows complex mixture of conformers, please see spectrum for details. Useful diagnostic peaks given.) $\delta 167.5,145.3,137.1$, 119.2 (q, $J=318.8 \mathrm{~Hz}$ ), 112.6, 110.1, 78.1, 54.4, 44.8, 37.3, 27.4, 27.1; LRMS (ESI) $\mathrm{m} / \mathrm{z}$ $719.18(\mathrm{M}+\mathrm{H})^{+}, 741.13(\mathrm{M}+\mathrm{Na})^{+}$; HRMS (ESI) $\mathrm{m} / z$ calcd for $\mathrm{C}_{38} \mathrm{H}_{33} \mathrm{~F}_{3} \mathrm{~N}_{2} \mathrm{O}_{7} \mathrm{~S} 719.2039$ $(\mathrm{M}+\mathrm{Na})^{+}$; found: 719.2054 . 


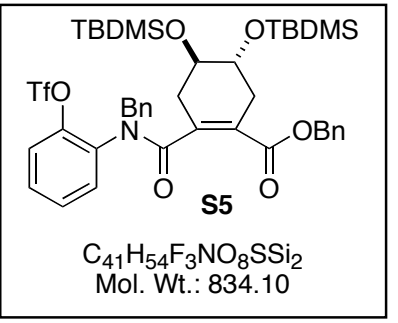

Disilyl Ether S5. tert-Butyldimethylsilyl triflate (3.75 g, 3.25 $\mathrm{mL}, 14.2 \mathrm{mmol}$ ) was added dropwise to a stirred solution of diol S3 (2.86 g, $4.73 \mathrm{mmol})$ and 2,6-lutidine (1.67 g, $1.82 \mathrm{~mL}, 15.6$ $\mathrm{mmol})$ in $\mathrm{CH}_{2} \mathrm{Cl}_{2}(50 \mathrm{~mL})$ at $0{ }^{\circ} \mathrm{C}$. The cold bath was removed upon completion of the addition, and the reaction was allowed to warm to room temperature. After $1 \mathrm{~h}$, the reaction was quenched by the addition saturated aqueous $\mathrm{NaHCO}_{3}(100 \mathrm{~mL})$ and diluted with $\mathrm{Et}_{2} \mathrm{O}(200 \mathrm{~mL})$. The resulting layers were separated, and the organic phase was washed with $1 \mathrm{M}$ aqueous citric acid $(2 \times 200 \mathrm{~mL})$, water $(2 \times 200 \mathrm{~mL})$ and brine $(1 \times 200 \mathrm{~mL})$. Drying $\left(\mathrm{MgSO}_{4}\right)$ and concentration in vacuo resulted in a yellow oil. Purification of this oil by column chromatography (90:10 to 70:30 hexanes-EtOAc) yielded $3.59 \mathrm{~g}(91 \%)$ of disilyl ether S5 as a clear, colorless oil: IR (film) 2934, 2860, 1714, 1668, 1424, 1247, $1096 \mathrm{~cm}^{-1} ;{ }^{1} \mathrm{H}$ NMR (500 MHz, CDCl ${ }_{3}$. Note: Spectrum shows complex mixture of conformers, please see spectrum for details. Useful diagnostic peaks given.) $\delta$ 7.34-7.51 (m), 7.26-7.34 (m), 7.18-7.25 (m), 7.06$7.16(\mathrm{~m}), 6.92-6.97(\mathrm{~m}), 6.82-6.90(\mathrm{~m}), 5.92-5.99(\mathrm{~m}), 5.06-5.28(\mathrm{~m}), 4.73-5.00(\mathrm{bm})$, 4.03 (bs), 0.77-0.98 (bm), $-0.04-0.17$ (m); ${ }^{13} \mathrm{C} \mathrm{NMR}\left(125 \mathrm{MHz}, \mathrm{CDCl}_{3}\right.$. Note: Spectrum shows complex mixture of conformers, please see spectrum for details. Useful diagnostic peaks given.) $\delta 170.7,165.8,128.5,118.4(\mathrm{q}, J=318.8), 66.8,53.6(\mathrm{~b}), 51.3,25.7,18.0$ (b), -3.63, -4.82 (b); LRMS (ESI) $m / z 834.46(\mathrm{M}+\mathrm{H})^{+}, 856.41(\mathrm{M}+\mathrm{Na})^{+}$; HRMS (ESI) calcd for $\mathrm{C}_{41} \mathrm{H}_{54} \mathrm{~F}_{3} \mathrm{NO}_{8} \mathrm{Si}_{2} \mathrm{~S}$ 856.2958 $(\mathrm{M}+\mathrm{Na})^{+}$; found 856.2972. Anal. Calcd for $\mathrm{C}_{41} \mathrm{H}_{54} \mathrm{~F}_{3} \mathrm{NO}_{8} \mathrm{Si}_{2} \mathrm{~S}: \mathrm{C}, 59.04 ; \mathrm{H}, 6.53 ; \mathrm{N}, 1.68$. Found: C, 59.12; H, 6.60; N, 1.70.

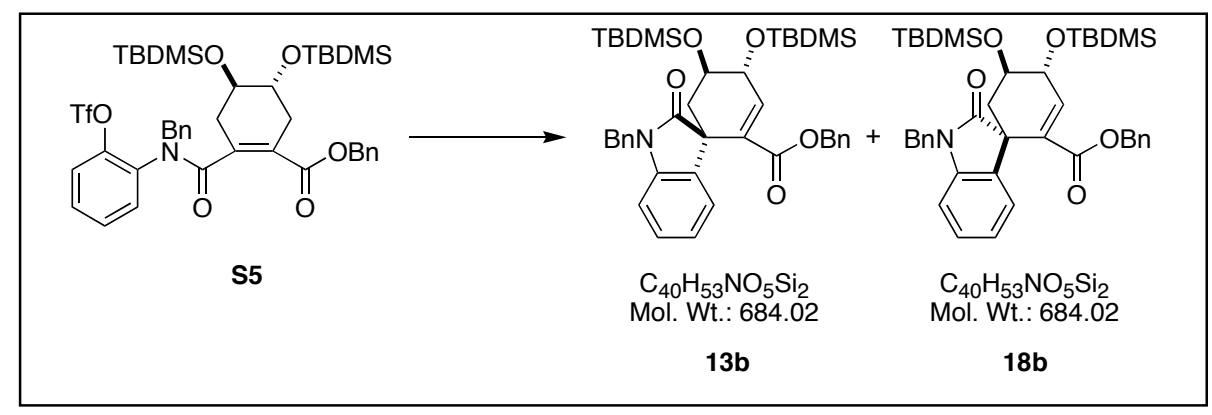

Preparation of 13b and 18b. In a nitrogen filled glovebox, a base-washed, glass vial containing a magnetic stir bar was charged with triflate S5 (232 mg, $0.278 \mathrm{mmol})$, $\mathrm{Pd}\left(\mathrm{PPh}_{3}\right)_{2} \mathrm{Cl}_{2}(39.0 \mathrm{mg}, 55.6 \mu \mathrm{mol}), \mathrm{Et}_{3} \mathrm{~N}(281 \mathrm{mg}, 0.39 \mathrm{~mL}, 2.78 \mathrm{mmol})$ and DMA (2.8 $\mathrm{mL}$ ). The vial was sealed with a Teflon-lined cap and placed in a $100{ }^{\circ} \mathrm{C}$ aluminum heating-block (bored to the diameter of the vial) atop a magnetic stir plate. The reaction was maintained with stirring for $24 \mathrm{~h}$ during which time the initial yellow suspension became a deep red, homogenous solution. The reaction was then cooled to room temperature, removed from the glovebox, opened to the atmosphere and diluted with $\mathrm{Et}_{2} \mathrm{O}(15 \mathrm{~mL})$. The resultant solution was washed with water $(2 \times 15 \mathrm{~mL})$ and brine $(1 \times$ $15 \mathrm{~mL}$ ), dried over $\mathrm{MgSO}_{4}$ and concentrated in vacuo. ${ }^{1} \mathrm{H} \mathrm{NMR}$ analysis of the crude reaction mixture showed a 40:60 mixture of diastereomers $\mathbf{1 3 b}$ and $\mathbf{1 8 b}$ along with trace unidentified isomers. Column chromatography (95:5 to 90:10 hexanes- $\mathrm{Et}_{2} \mathrm{O}$ ) allowed for partial separation of the isomers giving a combined yield of $148 \mathrm{mg}(79 \%)$. Major isomer 
18b was obtained as an analytically pure colorless oil. Minor isomer 13b was obtained at ca. $90 \%$ purity as a colorless oil. Compound $\mathbf{1 3 b}$ could be further purified by preparative HPLC (90:10 hexanes-EtOAc, $40 \mathrm{~mL} / \mathrm{min}, 300 \times 50 \mathrm{~mm}, 5 \mu \mathrm{m}$ silica gel column) to provide analytically pure material. The configurations of these products were assigned by comparison of their ${ }^{1} \mathrm{H}$ NMR spectra to those of the related methyl esters. ${ }^{5}$

Data for 13b: IR (film) 2956, 2929, 2858, 1719, 1611, 1252, $1115 \mathrm{~cm}^{-1} ;{ }^{1} \mathrm{H}$ NMR (500 MHz, $\left.\mathrm{CDCl}_{3}\right) \delta$ 7.21-7.31 (m, 8H), 7.14-7.20 (m, 3H), 6.96-7.00 (m, 3H), 6.61 (d, $J=7.8 \mathrm{~Hz}, 1 \mathrm{H}), 4.98(\mathrm{~d}, J=12.5 \mathrm{~Hz}, 1 \mathrm{H}), 4.93(\mathrm{~d}, J=15.8 \mathrm{~Hz}, 1 \mathrm{H}), 4.80(\mathrm{~d}, J=12.5$ $\mathrm{Hz}, 1 \mathrm{H}), 4.42-4.47$ (m, 2H), 4.09 (ddd, $J=12.0,7.6,3.5,1 \mathrm{H}), 2.32(\mathrm{t}, J=12.7 \mathrm{~Hz}, 1 \mathrm{H})$, $1.67(\mathrm{dd}, J=13.0,3.6 \mathrm{~Hz}, 1 \mathrm{H}), 0.97(\mathrm{~s}, 9 \mathrm{H}), 0.81(\mathrm{~s}, 9 \mathrm{H}), 0.20$ (s, 3H), 0.17 (s, 3H), 0.04 $(\mathrm{s}, 3 \mathrm{H}),-0.15(\mathrm{~s}, 3 \mathrm{H}) ;{ }^{13} \mathrm{C} \mathrm{NMR}\left(125 \mathrm{MHz}, \mathrm{CDCl}_{3}\right) \delta 178.6,163.9,147.6,142.3,136.0$, $135.4,133.2$, 128.7, 128.43, 128.37, 128.2, 128.0, 127.8, 127.5, 127.2, 122.9, 122.1, 109.6, 73.6, 70.1, 66.6, 52.0, 43.8, 41.4, 26.0,25.8, 18.2, 17.9, -4.0, -4.1, -4.7, -4.9; LRMS (ESI) $m / z 684.26(\mathrm{M}+\mathrm{H})^{+}, 706.27(\mathrm{M}+\mathrm{Na})^{+}$; HRMS (ESI) Calcd for $\mathrm{C}_{40} \mathrm{H}_{53} \mathrm{NO}_{5} \mathrm{Si}_{2}$ $m / z 684.3541(\mathrm{M}+\mathrm{H})^{+}$; found: 684.3558 .

Data for 18b: IR (film) 2929, 2858, 1717, 1613, 1252, $1100 \mathrm{~cm}^{-1} ;{ }^{1} \mathrm{H}$ NMR (500 $\left.\mathrm{MHz}, \mathrm{CDCl}_{3}\right) \delta 7.21-7.32(\mathrm{~m}, 8 \mathrm{H}), 7.10,7.15(\mathrm{~m}, 2 \mathrm{H}), 7.02(\mathrm{~d}, J=6.4 \mathrm{~Hz}, 1 \mathrm{H}), 6.92-$ $6.97(\mathrm{~m}, 3 \mathrm{H}), 6.57(\mathrm{~d}, 7.8 \mathrm{~Hz}, 1 \mathrm{H}), 4.99(\mathrm{~d}, J=15.6 \mathrm{~Hz}, 1 \mathrm{H}), 4.85(\mathrm{~d}, J=12.2 \mathrm{~Hz}, 1 \mathrm{H})$, $4.73(\mathrm{~d}, J=12.2 \mathrm{~Hz}, 1 \mathrm{H}), 4.48-5.54(\mathrm{~m}, 1 \mathrm{H}), 4.33(\mathrm{dd}, J=7.3,2.0 \mathrm{~Hz}, 1 \mathrm{H}), 4.09(\mathrm{~d}, J=$ $15.6 \mathrm{~Hz}, 1 \mathrm{H}), 1.89-1.99(\mathrm{~m}, 2 \mathrm{H}), 0.97(\mathrm{~s}, 9 \mathrm{H}), 0.86(\mathrm{~s}, 9 \mathrm{H}), 0.20$ (s, 3H), $0.16(\mathrm{~s}, 3 \mathrm{H})$, $0.10(\mathrm{~s}, 3 \mathrm{H}), 0.07(\mathrm{~s}, 3 \mathrm{H}) ;{ }^{13} \mathrm{C}$ NMR $\left(125 \mathrm{MHz}, \mathrm{CDCl}_{3}\right) \delta 177.9,164.8,147.6,142.6$, $136.3,135.2$, 133.3, 129.3, 128.7, 128.4, 128.3, 128.1, 128.0, 127.5, 127.4, 122.5, 122.4, 109.0, 73.3, 68.9, 66.7, 51.1, 43.5, 40.9, 26.0 (b), 18.1, 17.9, -4.1, -4.2, -4.7, -4.8; LRMS (ESI) $m / z 684.24(\mathrm{M}+\mathrm{H})^{+}, 706.22(\mathrm{M}+\mathrm{Na})^{+}$; HRMS (ESI) Calcd for $\mathrm{C}_{40} \mathrm{H}_{53} \mathrm{NO}_{5} \mathrm{Si}_{2}$ $m / z 684.3541(\mathrm{M}+\mathrm{H})^{+}$; found: 684.3557 .

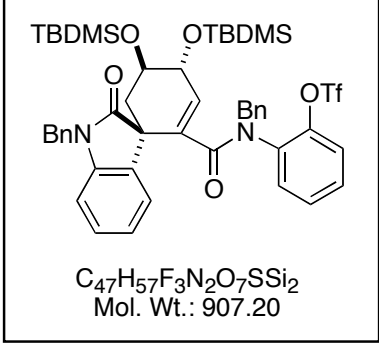

Disilyl Ether 17b. A solution of benzyl ester 13b (693 mg, 1.01 $\mathrm{mmol})$ in EtOAc $(30 \mathrm{~mL})$ was placed under a atmosphere of $\mathrm{N}_{2}$. $\mathrm{Pd} / \mathrm{C}$ (120 mg, 10\% wt, $50 \%$ water Degaussa Type) was added and the atmosphere was replaced with $\mathrm{H}_{2}$ (balloon). The reaction was rapidly stirred for $1.5 \mathrm{~h}$ at which time TLC analysis indicated complete ester cleavage. The flask was vented and the reaction was filtered through a plug of Celite ${ }^{\circledR}$, washing with EtOAc. The filtrate was then concentrated in vacuo to give a colorless solid. The resulting crude acid $\mathbf{1 4 b}$ was then azetropically dried from benzene twice before being dried under vacuum $(c a .0 .05 \mathrm{mmHg}$ ) for $2 \mathrm{~h}$. This material was used without further purification.

The crude acid, $i$ - Pr $_{2} \mathrm{NEt}(635 \mathrm{mg}, 0.89 \mathrm{~mL}, 4.91 \mathrm{mmol})$ and aniline 15 (920 $\mathrm{mg}$, $2.95 \mathrm{mmol}$ ) were dissolved in MeCN (10 mL). After $10 \mathrm{~min}$, BOP-Cl (375 mg, 1.45 mmol) was added and the resulting solution was maintained for $18 \mathrm{~h}$. The reaction was then quenched by the addition of water $(5 \mathrm{~mL})$ and extracted with $\mathrm{Et}_{2} \mathrm{O}(3 \times 30 \mathrm{~mL})$. The combined organics were dried $\left(\mathrm{MgSO}_{4}\right)$ and concentrated in vacuo to give a crude yellow oil. This oil was purified by column chromatography (95:5 hexanes-EtOAc) to give 438 $\mathrm{mg}(50 \%)$ of silyl phenol $\mathbf{1 6 b}$ as a colorless oil.

The siloxy phenol 16b $(310 \mathrm{mg}, 348 \mu \mathrm{mol})$ was then dissolved in DMF (10 mL) and the resulting solution was sparged with a dry steam of Ar for $5 \mathrm{~min} . \mathrm{Cs}_{2} \mathrm{CO}_{3}(568 \mathrm{mg}$, 
$1.74 \mathrm{mmol}$ ), $\mathrm{CsF}$ (526 mg, $3.48 \mathrm{mmol}$ ) were then added resulting suspension was rapidly stirred for $30 \mathrm{~min}$. TLC analysis then indicated that the starting material had been consumed and intermediate phenol was observed. PhNTf $_{2}(168 \mathrm{mg}, 383 \mu \mathrm{mol})$ was added and the reaction was maintained for an additional $10 \mathrm{~min}$. TLC analysis then indicated complete consumption of the phenol. The reaction was diluted with EtOAc $(30 \mathrm{~mL})$ and washed with water $(2 \times 15 \mathrm{~mL})$ and brine $(15 \mathrm{~mL})$. The resulting solution was dried $\left(\mathrm{MgSO}_{4}\right)$ and concentration in vacuo gave a crude, yellow oil. Purification of this oil by column chromatography (93:7 hexanes-EtOAc) gave $241 \mathrm{mg}(76 \%)$ of bis-silyl ether 17b as a colorless foam: IR (film) 2956, 2931, 2858, 1710, 1640, 1495, 1218, $1100 \mathrm{~cm}^{-1}$; ${ }^{1} \mathrm{H}$ NMR (500 MHz, $\left.\mathrm{C}_{6} \mathrm{D}_{6}\right) \delta 8.01$ (bs, $\left.1 \mathrm{H}\right), 7.30(\mathrm{~d}, J=7.4 \mathrm{~Hz}, 2 \mathrm{H}), 7.22(\mathrm{~d}, J=7.3 \mathrm{~Hz}$, $1 \mathrm{H}), 7.14-7.17(\mathrm{~m}, 1 \mathrm{H}), 7.07$ (t. $J=7.3 \mathrm{~Hz}, 2 \mathrm{H}), 6.85-7.00(\mathrm{~m}, 7 \mathrm{H}), 6.74(\mathrm{t}, J=7.5 \mathrm{~Hz}$, $1 \mathrm{H}), 6.64(\mathrm{bs}, 1 \mathrm{H}), 6.54(\mathrm{t}, J=7.6 \mathrm{~Hz}, 1 \mathrm{H}), 6.47(\mathrm{~d}, J=7.7,1 \mathrm{H}), 6.00-6.10(\mathrm{~m}, 2 \mathrm{H}), 4.98$ $(\mathrm{d}, J=16.2 \mathrm{~Hz}, 1 \mathrm{H}), 4.46(\mathrm{~d}, J=16.2 \mathrm{~Hz}, 1 \mathrm{H}), 4.42(\mathrm{bs}, 1 \mathrm{H}), 4.29$ (d, $J=15.1 \mathrm{~Hz}, 1 \mathrm{H})$, $4.11(\mathrm{bs}, 1 \mathrm{H}), 2.55$ (bt, $J=11.8 \mathrm{~Hz}, 1 \mathrm{H}), 1.92$ (bd, $J=11.0 \mathrm{~Hz}, 1 \mathrm{H}), 1.02(\mathrm{~s}, 9 \mathrm{H}), 0.82$ (s, $9 \mathrm{H}), 0.12(\mathrm{~s}, 3 \mathrm{H}), 0.08(\mathrm{~s}, 3 \mathrm{H}),-0.14(\mathrm{~s}, 3 \mathrm{H}),-0.18(\mathrm{~s}, 3 \mathrm{H}) ;{ }^{13} \mathrm{C}$ NMR $\left(125 \mathrm{MHz}, \mathrm{C}_{6} \mathrm{D}_{6}\right)$ $\delta 179.7,168.5,143.2,136.7,136.6,135.5,131.7,129.8,129.8,129.5,129.3,129.1$, $128.9,128.7,128.5,128.3,128.0,127.9,127.5,123.8,122.9,122.6,119.3$ (q, $J=317.5$ Hz), 110.3, 74.6, 70.7, 55.4, 51.6, 44.2, 42.8, 26.5, 26.4, 18.44, 18.37, -3.3, -3.6, -4.3, 4.6; LRMS (ESI) $m / z$, $907.74(\mathrm{M}+\mathrm{H})^{+}, 929.72(\mathrm{M}+\mathrm{Na})^{+}$; HRMS (ESI) $\mathrm{m} / z$ calcd for $\mathrm{C}_{47} \mathrm{H}_{57} \mathrm{~F}_{3} \mathrm{~N}_{2} \mathrm{O}_{7} \mathrm{SSi}_{2}$ 907.3455 $(\mathrm{M}+\mathrm{H})^{+}$; found: 907.3466. The ${ }^{1} \mathrm{H}$ NMR spectrum was also recorded in $\mathrm{d}_{8}$-toluene at $100{ }^{\circ} \mathrm{C}$, see spectra for details.

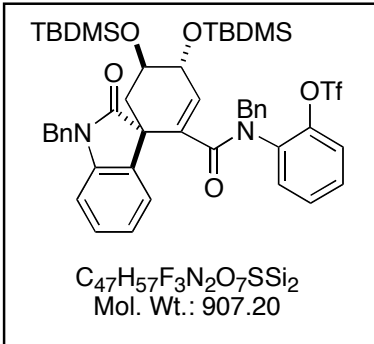

Disilyl Ether 21b. A solution of benzyl ester 18b (400 mg, 585 $\mu \mathrm{mol})$ in EtOAc $(30 \mathrm{~mL})$ was placed under a atmosphere of $\mathrm{N}_{2}$. $\mathrm{Pd} / \mathrm{C}$ (80 mg, 10\% wt, $50 \%$ water Degaussa Type) was added and the atmosphere was replaced with $\mathrm{H}_{2}$ (balloon). The reaction was rapidly stirred for $1.5 \mathrm{~h}$, at which time TLC analysis indicated complete ester cleavage. The flask was vented and the reaction was filtered through a plug of Celite ${ }^{\circledR}$, washing with EtOAc. The filtrate which was then concentrated in vacuo to give a colorless solid. The resulting crude acid 19b was then azetropically dried from benzene twice before being dried under vacuum (ca. $0.05 \mathrm{mmHg}$ ) for $2 \mathrm{~h}$. This material was used without further purification.

The crude acid, $i$ - $\operatorname{Pr}_{2} \mathrm{NEt}(378 \mathrm{mg}, 0.51 \mathrm{~mL}, 2.92 \mathrm{mmol})$ and aniline 15 (549 $\mathrm{mg}$, $1.75 \mathrm{mmol}$ ) were dissolved in $\mathrm{MeCN}$ (10 mL). After $10 \mathrm{~min}$, BOP-Cl (223 mg, 877 $\mu \mathrm{mol}$ ) was added and the resulting solution was maintained for $18 \mathrm{~h}$. The reaction was then quenched by the addition of water $(5 \mathrm{~mL})$ and extracted with $\mathrm{Et}_{2} \mathrm{O}(3 \times 30 \mathrm{~mL})$. The combined organics were dried $\left(\mathrm{MgSO}_{4}\right)$ and concentrated in vacuo to give a crude yellow oil. This oil was purified by column chromatography (95:5 hexanes-EtOAc) to give 130 $\mathrm{mg}(25 \%)$ of silyl phenol $\mathbf{2 0 b}$ as a colorless oil.

The siloxy phenol 20b (129 mg, $145 \mu \mathrm{mol})$ was then dissolved in DMF (3 mL) and the resulting solution was sparged with a dry steam of Ar for $5 \mathrm{~min} . \mathrm{Cs}_{2} \mathrm{CO}_{3}(236 \mathrm{mg}$, $723 \mu \mathrm{mol}), \mathrm{CsF}(109 \mathrm{mg}, 723 \mu \mathrm{mol})$ and $\operatorname{PhNTf}_{2}(103 \mathrm{mg}, 289 \mu \mathrm{mol})$ were added sequentially and the resulting suspension was rapidly stirred for $4 \mathrm{~h}$. TLC analysis then indicated that the starting material had been consumed but intermediate phenol remained. A second charge of $\operatorname{PhNTf}_{2}(103 \mathrm{mg}, 289 \mu \mathrm{mol})$ was added and the reaction was 
maintained for an $10 \mathrm{~min}$. TLC analysis then indicated complete consumption of the phenol. The reaction was diluted with EtOAc $(30 \mathrm{~mL})$ and washed with water $(2 \times 15$ $\mathrm{mL})$ and brine $(15 \mathrm{~mL})$. The resulting solution was dried $\left(\mathrm{MgSO}_{4}\right)$ and concentration in vacuo gave a crude, yellow oil. Purification of this oil by column chromatography (93:7 hexanes-EtOAc) gave $112 \mathrm{mg}(86 \%)$ of bis-silyl ether $\mathbf{2 1 b}$ as a colorless foam: IR (film) 2954, 2931, 2858, 1717, 1657, 1636, 1611, 1492, 1219, $1098 \mathrm{~cm}^{-1} ;{ }^{1} \mathrm{H}$ NMR $(500 \mathrm{MHz}$, $\mathrm{C}_{6} \mathrm{D}_{6}$. Note: Spectrum shows complex mixture of conformers, please see spectrum for details. Useful diagnostic peaks given.) $\delta 7.35(\mathrm{bs}), 6.78-7.10(\mathrm{bm}), 6.50-6.70(\mathrm{bm}), 5.95$ (bd), 5.10 (bd), 4.55 (bs), 3.95 (bs), 0.99 (s), 0.94 (s), 0.17 (bs), -0.11 (bs); ${ }^{13} \mathrm{C} \mathrm{NMR}$ (125 MHz, $\mathrm{C}_{6} \mathrm{D}_{6}$. Note: Spectrum shows complex mixture of conformers, please see spectrum for details. Useful diagnostic peaks given.) $\delta 178.1,167.5,145.5,145.3,137.5$, $137.2,123.4,120.5,119.4$ (q, $J=317.5 \mathrm{~Hz}$ ), 110.0, 73.7, 69.1, 53.3, 52.6, 44.8, 41.0, 26.7, 26.5, 18.5, 18.4, -3.48, -3.53, -4.2, -4.5; LRMS (ESI) $m / z 907.72(\mathrm{M}+\mathrm{H})^{+}, 929.71$ $(\mathrm{M}+\mathrm{Na})^{+}$; HRMS (ESI) $\mathrm{m} / z$ calcd for $\mathrm{C}_{47} \mathrm{H}_{57} \mathrm{~F}_{3} \mathrm{~N}_{2} \mathrm{O}_{7} \mathrm{SSi}_{2} 907.3455(\mathrm{M}+\mathrm{H})^{+}$; found: 907.3456. The ${ }^{1} \mathrm{H} \mathrm{NMR}$ spectrum was also recorded in $\mathrm{d}_{8}$-toluene at $100{ }^{\circ} \mathrm{C}$ and $\mathrm{CDCl}_{3}$ at room temperature, see spectra for details.

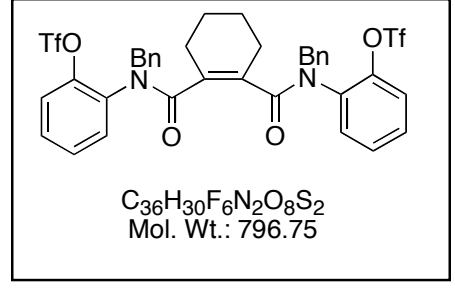

Ditriflate 23. A solution of diphenol $22^{5}(3.0 \mathrm{~g}, 5.57 \mathrm{mmol})$ in 4:1 EtOH-EtOAc $(250 \mathrm{~mL})$ was placed under an atmosphere of nitrogen. Palladium on carbon $(300 \mathrm{mg}, 10 \%$ wt with $50 \%$ water, Degaussa type) was added and the resulting rapidly stirred suspension was placed under an atmosphere of $\mathrm{H}_{2}$ (balloon). After $4.5 \mathrm{~h}$, the reaction was vented, and the solution was filtered trough a plug of Celite ${ }^{\circledR}$ washing with EtOAc. The filtrate was then concentrated in vacuo to provide the reduced diphenol as an unstable cream-colored solid.

The crude reduced diphenol was then dissolved in DMF $(85 \mathrm{~mL})$ and $\mathrm{Cs}_{2} \mathrm{CO}_{3}$ (9.17 g, $28.2 \mathrm{mmol})$ and $\mathrm{PhNTf}_{2}(10.1 \mathrm{~g}, 28.2 \mathrm{mmol})$ were added. The resulting suspension was stirred for $1 \mathrm{~h}$ before being diluted with $\mathrm{Et}_{2} \mathrm{O}(100 \mathrm{~mL})$. The solution was then washed with water $(2 \times 100 \mathrm{~mL})$ and brine $(100 \mathrm{~mL})$. The organic phase was then dried $\left(\mathrm{MgSO}_{4}\right.$ and concentrated in vacuo to provide a crude oil. Purification of this oil by column chromatography (90:10 hexanes-EtOAc) provided $3.88 \mathrm{~g}(87 \%)$ of ditriflate 23 was a colorless solid. This material could also be recrystallized (hot hexanes) to provide colorless prisms: $\mathrm{mp}=61-63{ }^{\circ} \mathrm{C}$ (hexanes); IR (film) 3037, 2941, 1644, 1607, 1481, $1220,1139 \mathrm{~cm}^{-1}$; ${ }^{1} \mathrm{H}$ NMR $\left(500 \mathrm{MHz}, \mathrm{CDCl}_{3}\right.$. Note: Spectrum shows complex mixture of conformers, please see spectrum for details. Useful diagnostic peaks given.) $\delta 8.27-8.29$ (m), 8.13 (d, $J=7.5), 7.17-7.43(\mathrm{~m}), 5.86-5.94(\mathrm{~m}), 5.17$ (d, $J=14.1 \mathrm{~Hz}), 5.02$ (d, $J=$ 14.1 Hz), 4.31-4.38 (m); ${ }^{13} \mathrm{C}$ NMR (125 MHz, $\mathrm{CDCl}_{3}$. Note: Spectrum shows complex mixture of conformers, please see spectrum for details. Useful diagnostic peaks given.) $\delta 171.9,144.0,137.3,134.6,128.3,127.4,121.1,118.4$ (q, $J=317.5), 50.6,25.5,21.0$; LRMS (ESI) $m / z 818.97(\mathrm{M}+\mathrm{Na})^{+}$; HRMS (ESI) $\mathrm{m} / z$ calcd for $\mathrm{C}_{36} \mathrm{H}_{30} \mathrm{~F}_{6} \mathrm{~N}_{2} \mathrm{O}_{8} \mathrm{~S}_{2} 891.1123$ $(\mathrm{M}+\mathrm{Na})^{+}$; found: 819.1246. Anal. Calcd for $\mathrm{C}_{36} \mathrm{H}_{30} \mathrm{~F}_{6} \mathrm{~N}_{2} \mathrm{O}_{8} \mathrm{~S}_{2}: \mathrm{C}, 54.27$; H, 3.80; N, 3.52. Found: C, 54.27; H, 3.69; N, 3.52. 


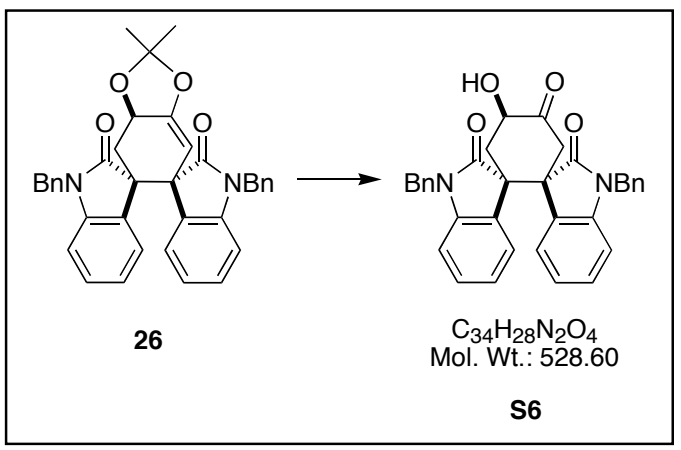

Conversion of Acetonide 26 to Keto-Alcohol S6. A solution of acetonide $4-32(9.0 \mathrm{mg})$ and TFA (2 drops) in 3:1 THF-water $(1 \mathrm{~mL})$ was heated to reflux for $2 \mathrm{~h}$. After this time, TLC analysis indicated no starting material remained. The reaction was cooled to room temperature, diluted with EtOAc $(5 \mathrm{~mL})$ and washed with saturated aqueous $\mathrm{NaHCO}_{3}(5$ $\mathrm{mL})$ and brine $(5 \mathrm{~mL})$. Drying $\left(\mathrm{MgSO}_{4}\right)$ and concentration in vacuo provided $7 \mathrm{mg}$ of a crude oil. Analysis by ${ }^{1} \mathrm{H}$ NMR demonstrated this material to be the previously characterized keto-alcohol S6. ${ }^{8}$ This material was not purified further.

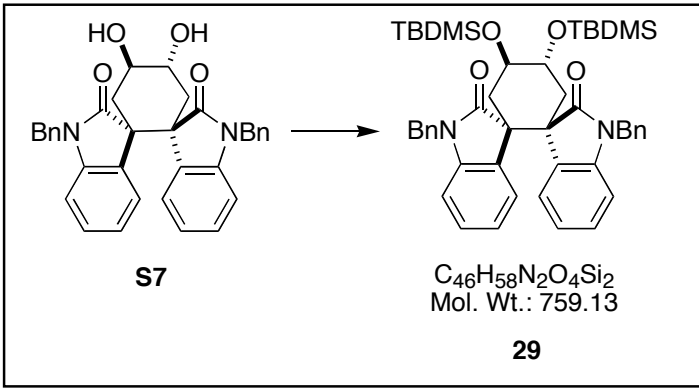

Independent Preparation of Disilyl Ether 29. tert-Butyldimethylsilyl triflate $(190 \mathrm{mg}$, $165 \mu \mathrm{L}, 718 \mu \mathrm{mol})$ was added to a solution of diol $\mathbf{S 7}^{9}(50.0 \mathrm{mg}, 94.2 \mu \mathrm{mol})$ and $2,6-$ lutidine (101 mg, $110 \mu \mathrm{L}, 942 \mu \mathrm{mol})$ in $\mathrm{CH}_{2} \mathrm{Cl}_{2}(1 \mathrm{~mL})$ at $0{ }^{\circ} \mathrm{C}$. The cold bath was removed and the reaction was allowed to warm to room temperature, were it was maintained for $12 \mathrm{~h}$. TLC analysis indicated complete conversion of the starting material. The reaction was quenched by the addition of saturated aqueous $\mathrm{NaHCO}_{3}(1 \mathrm{~mL})$ then diluted with $\mathrm{Et}_{2} \mathrm{O}(15 \mathrm{~mL})$. The layers were separated, and the organic phase was washed with $1 \mathrm{M}$ citric acid $(2 \times 10 \mathrm{~mL})$, saturated aqueous $\mathrm{NaHCO}_{3}(10 \mathrm{~mL})$, water $(10 \mathrm{~mL})$ and brine $(10 \mathrm{~mL})$. Drying $\left(\mathrm{MgSO}_{4}\right)$ and concentration in vacuo provided a crude oil. Purification of this oil by column chromatography $\left(90: 10\right.$ hexanes- $\left.\mathrm{Et}_{2} \mathrm{O}\right)$ provided $39.8 \mathrm{mg}(56 \%)$ disilyl ether 29 as a colorless solid. Analytical data match that reported for $\mathbf{2 9}$ in the main text of this article.

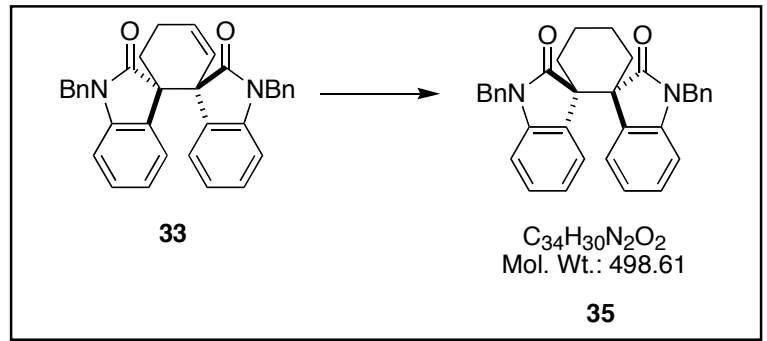

Conversion of Cyclohexene 33 to Cyclohexane 35. Formic acid (1 drop) was added to a solution of alkene $\mathbf{3 3}$ (13.0 mg, $26.2 \mu \mathrm{mol})$ in 1:1 EtOAc-EtOH $(1 \mathrm{~mL})$. The solution was placed under an atmosphere of $\mathrm{N}_{2}$ and $\mathrm{Pd} / \mathrm{C}(5 \mathrm{mg}, 10 \mathrm{wt}$ $\%$, 50\% water, Degaussa Type) was added. The resulting suspension was then placed under $\mathrm{H}_{2}(1500 \mathrm{psi})$ and stirred rapidly for $18 \mathrm{~h}$ at $\mathrm{rt}$. The reactor was then vented and solution filtered through a pad of Celite, washing with EtOAc. Concentration in

${ }^{8}$ Stearns, B. A. Ph.D. Dissertation, University of California, Irvine, CA, 2000.

${ }^{9}$ Overman, L. E.; Larrow, J. F.; Stearns, B. A.; Vance, J. M. Angew. Chem., In. Ed. 2000, $39,213-215$. 
vacuo and purification by column chromatography provided $11.5 \mathrm{mg}$ (88\%) of cyclohexane $\mathbf{3 5}$ as colorless solid. Slow diffusion of hexanes into a solution of $\mathbf{3 5}$ provided crystals suitable for X-ray crystallographic analysis: IR (film) 3033, 2960, 2925 , 1694, 1609, 1366, $1175 \mathrm{~cm}^{-1}$; ${ }^{1} \mathrm{H}$ NMR (500 MHz, $\left.\mathrm{CDCl}_{3}\right) \delta 7.23-7.30$ (m, 4H), 7.16$7.18(\mathrm{~m}, 8 \mathrm{H}), 6.96(\mathrm{td}, J=7.7,1.1 \mathrm{~Hz}, 2 \mathrm{H}), 6.71(\mathrm{td}, J=7.6,0.7 \mathrm{~Hz}, 2 \mathrm{H}), 6.45(\mathrm{~d}, J=7.8$ $\mathrm{Hz}, 2 \mathrm{H}), 4.90(\mathrm{~d}, J=15.7 \mathrm{~Hz}, 2 \mathrm{H}), 4.79(\mathrm{~d}, J=15.7 \mathrm{~Hz}, 2 \mathrm{H}), 2.95-3.05(\mathrm{~m}, 2 \mathrm{H}), 2.54$ (bt, $J=9.3 \mathrm{~Hz}, 2 \mathrm{H}), 1.60(\mathrm{~d}, J=13.8 \mathrm{~Hz}, 2 \mathrm{H}) ;{ }^{13} \mathrm{C} \mathrm{NMR}\left(125 \mathrm{MHz}, \mathrm{CDCl}_{3}\right) \delta 177.7$, $142.1,135.7,131.2,128.6,127.8,127.43,127.39,124.3,122.3,108.5,50.2,43.4,34.3$, 29.9, 19.2; LRMS (ESI) $\mathrm{m} / z 499.29(\mathrm{M}+\mathrm{H})^{+}, 521.27(\mathrm{M}+\mathrm{Na})^{+}$; HRMS (ESI) calcd for $\mathrm{C}_{34} \mathrm{H}_{30} \mathrm{~N}_{2} \mathrm{O}_{2} \mathrm{~m} / z$ 499.2386 (M+Na) ${ }^{+}$; found:: 499.2375 . 


\section{Crystallographic Data: ${ }^{10}$}

\section{Solid State Structure of 13a.}
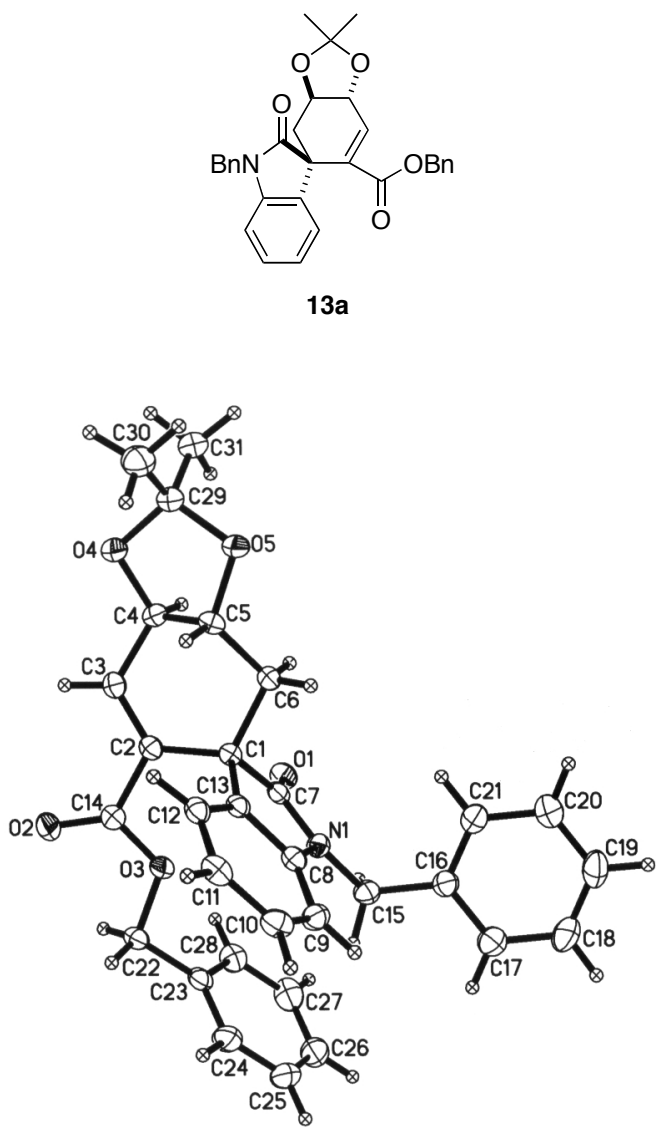

${ }^{10} \mathrm{CIF}$ files for all structures have been provided in separate files, which are available for download. 
Solid State Structure of 32.

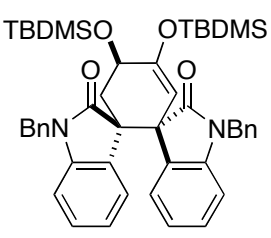

32

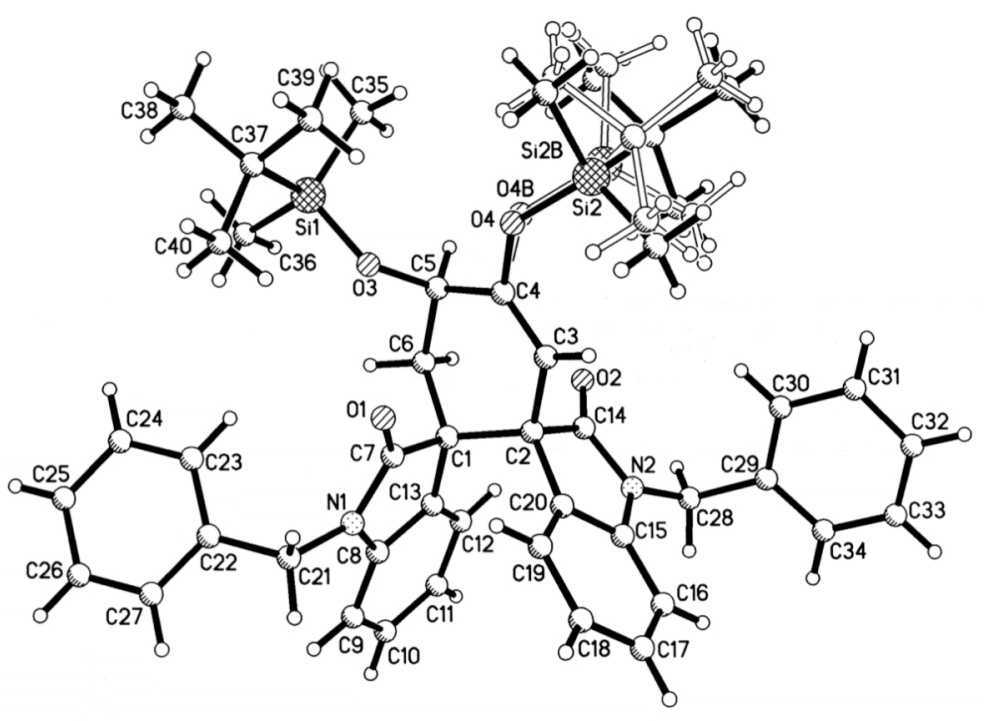

Solid State Structure of 35 .

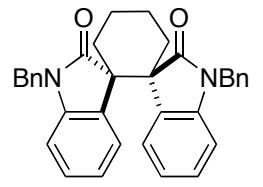

35

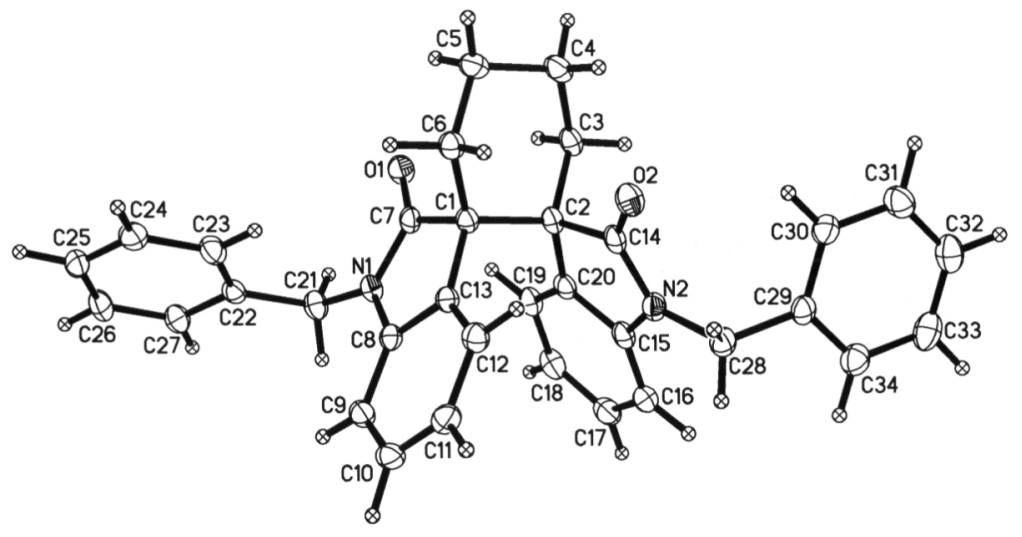




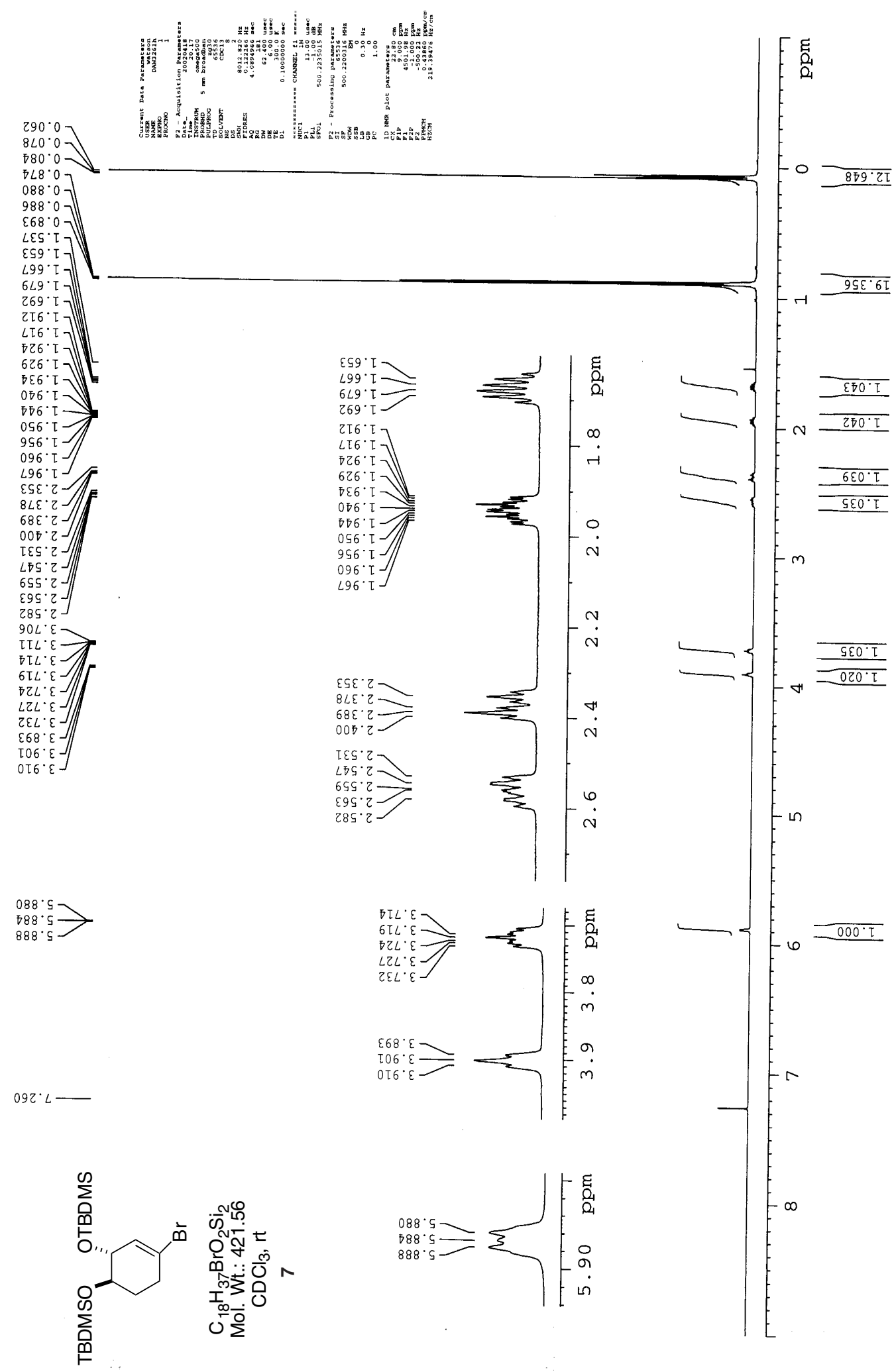



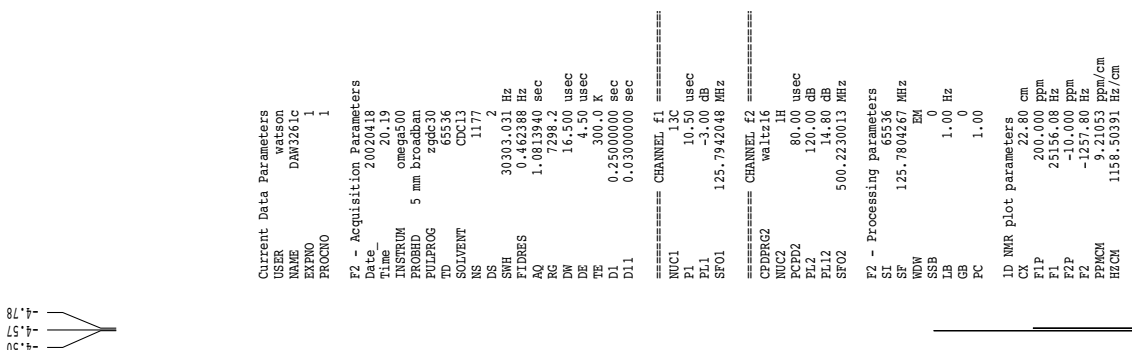

${ }^{25^{\circ}+7-}=$

$70 \% 81$
60.81

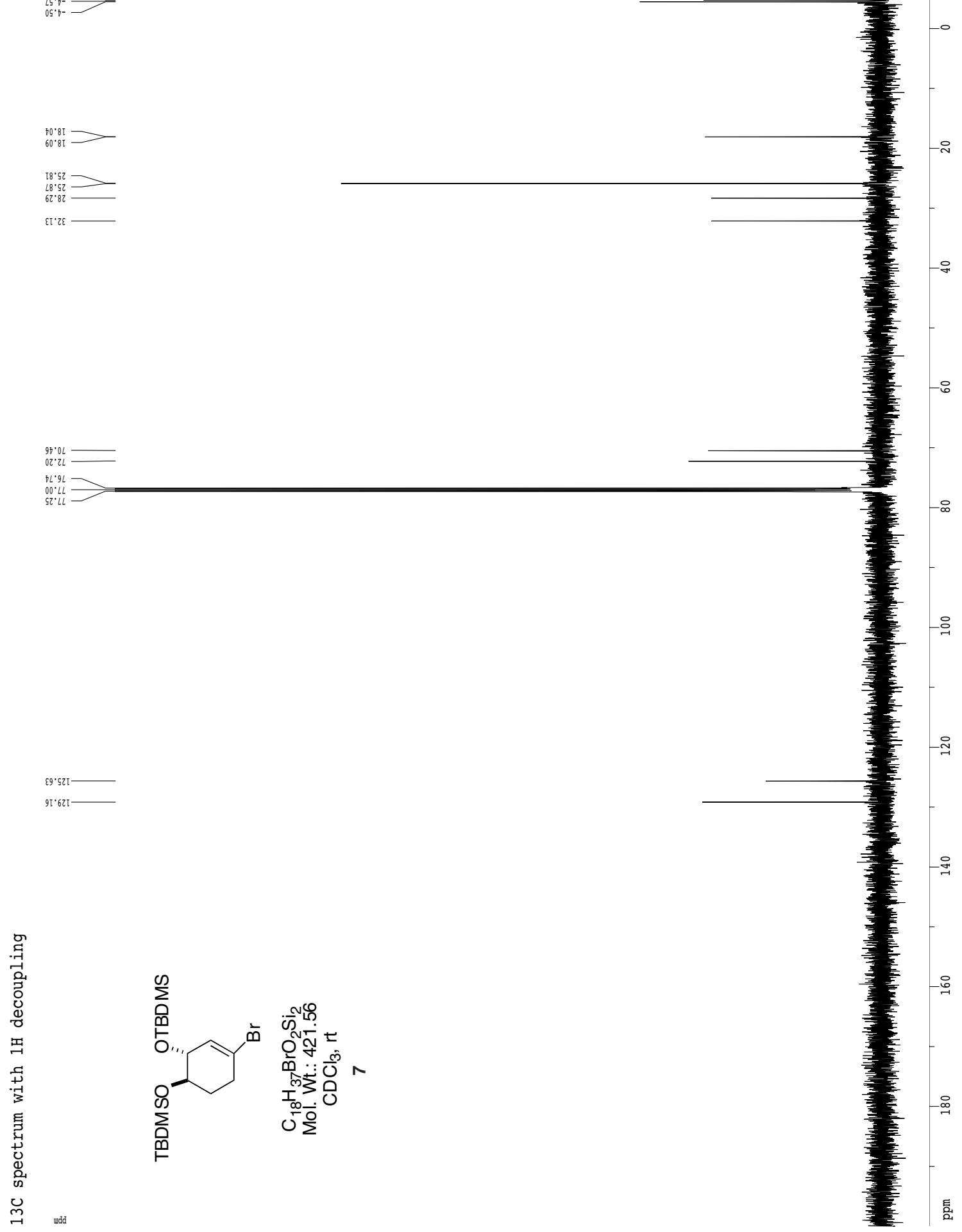

ยเ'ว -

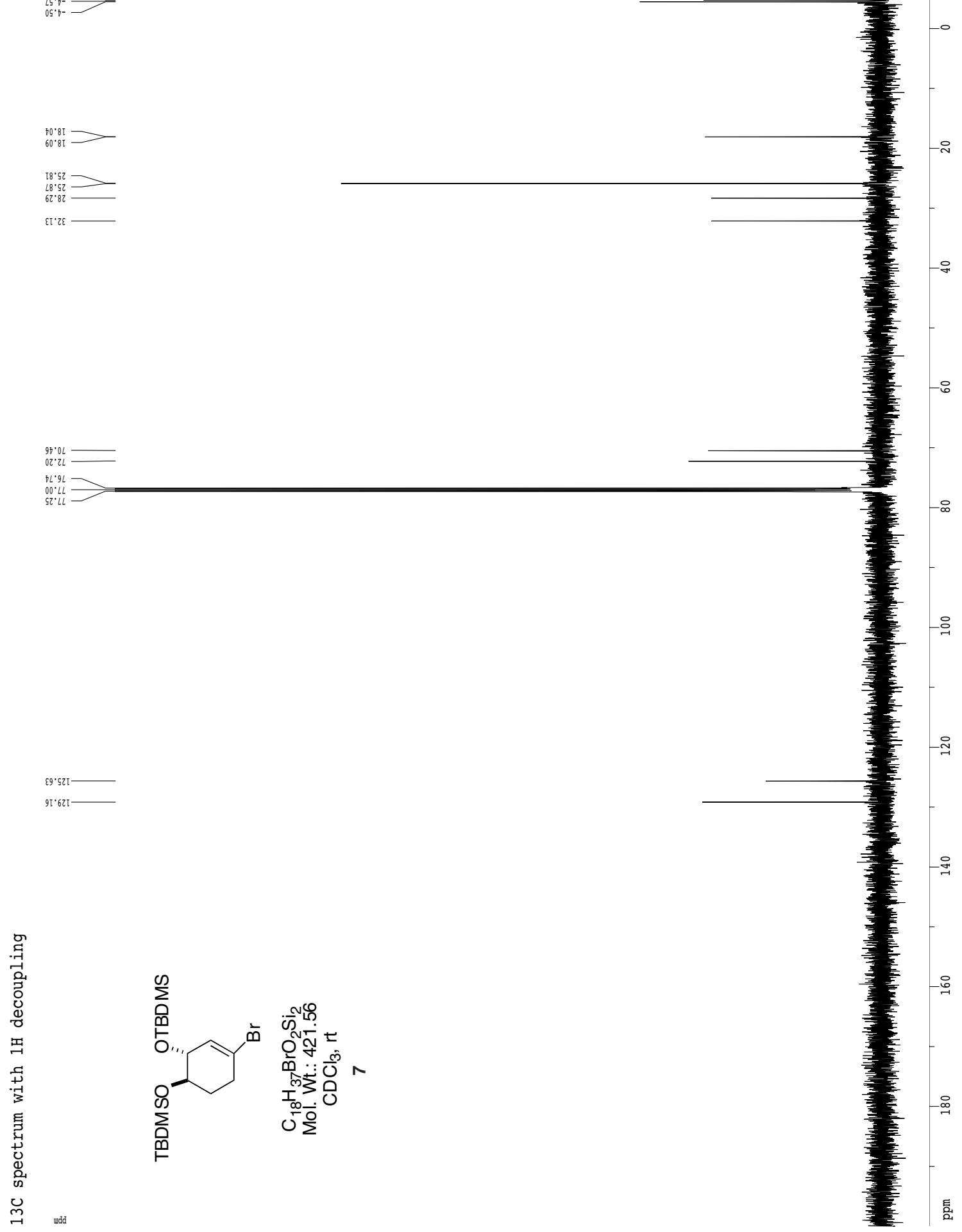

$\varepsilon 9^{\circ}$ c โ -

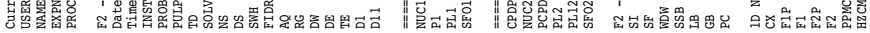



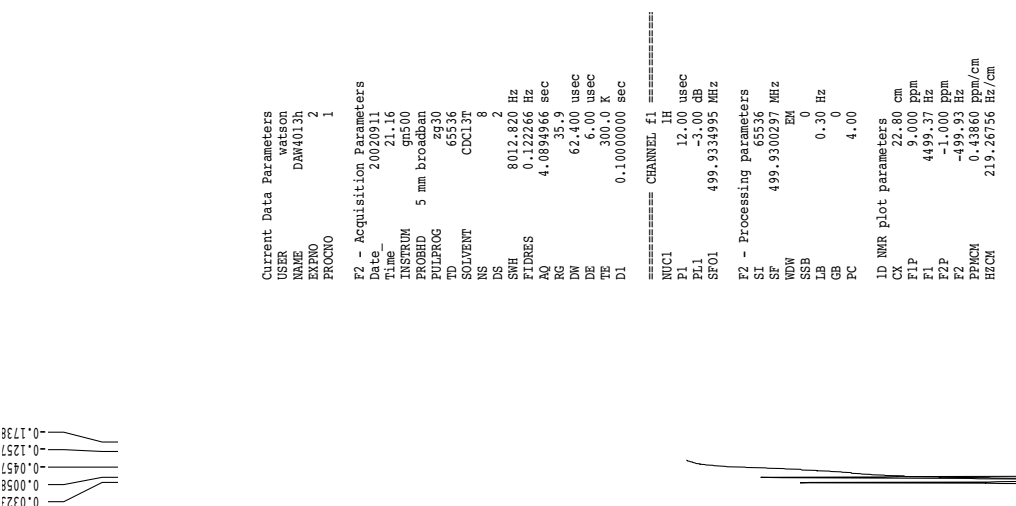

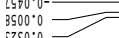

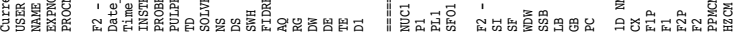

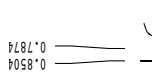

$25 f 95^{\circ} \mathrm{T}-$

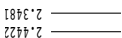

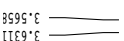

b9ז'

$399 \varepsilon^{\circ}$

วโโ8・ร
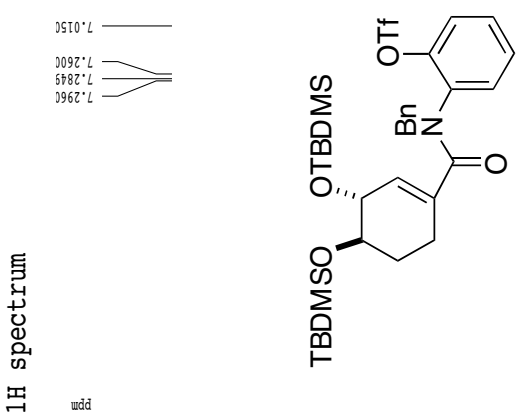

कึก

भ००ें

유

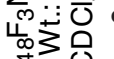

लुले

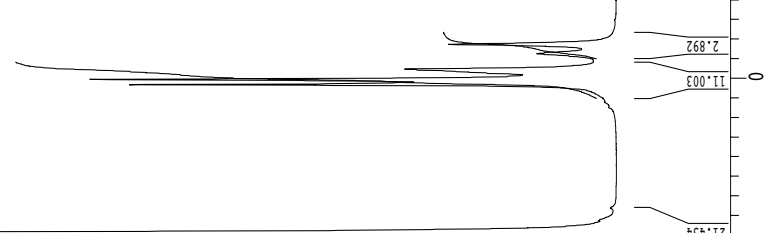




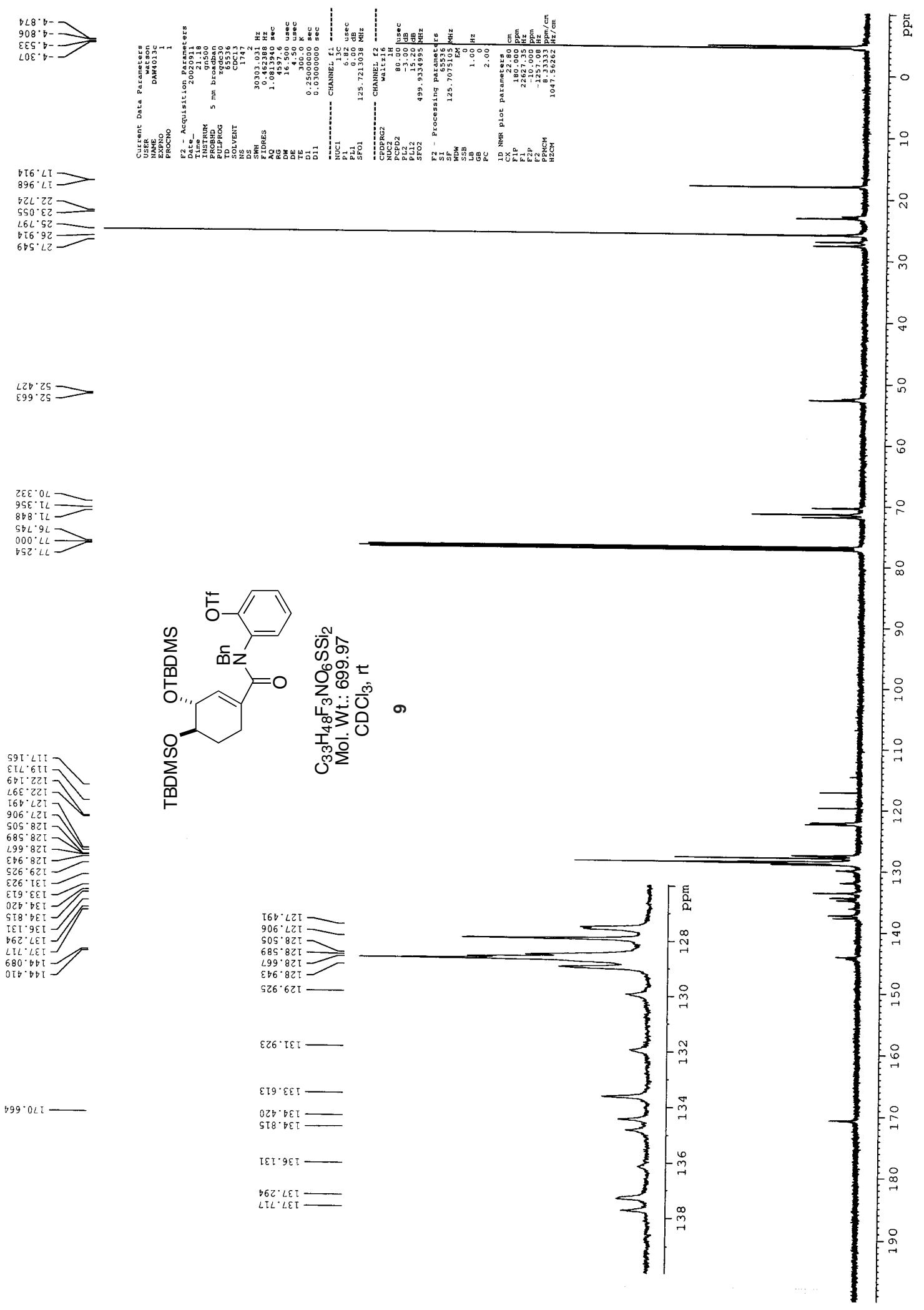



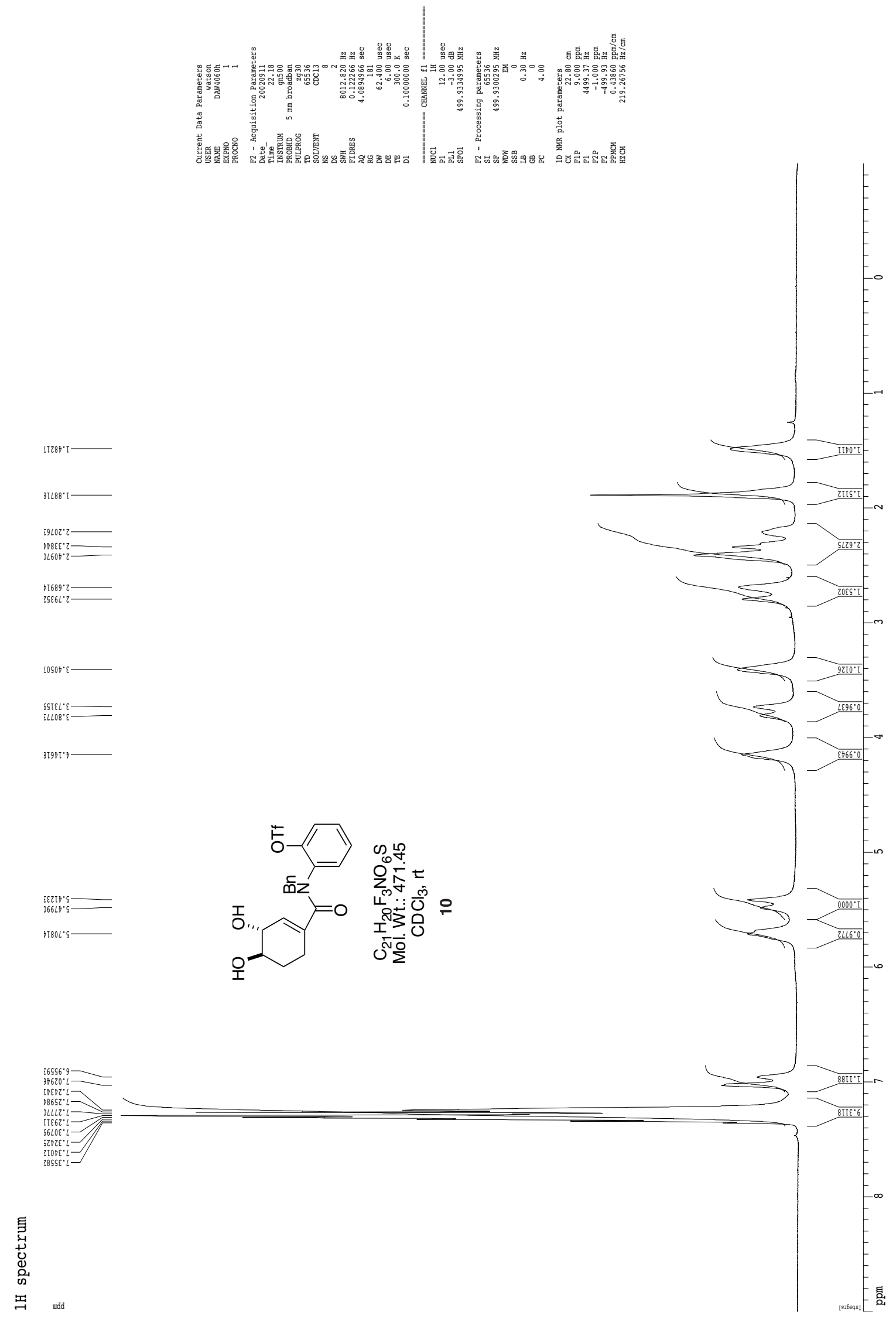

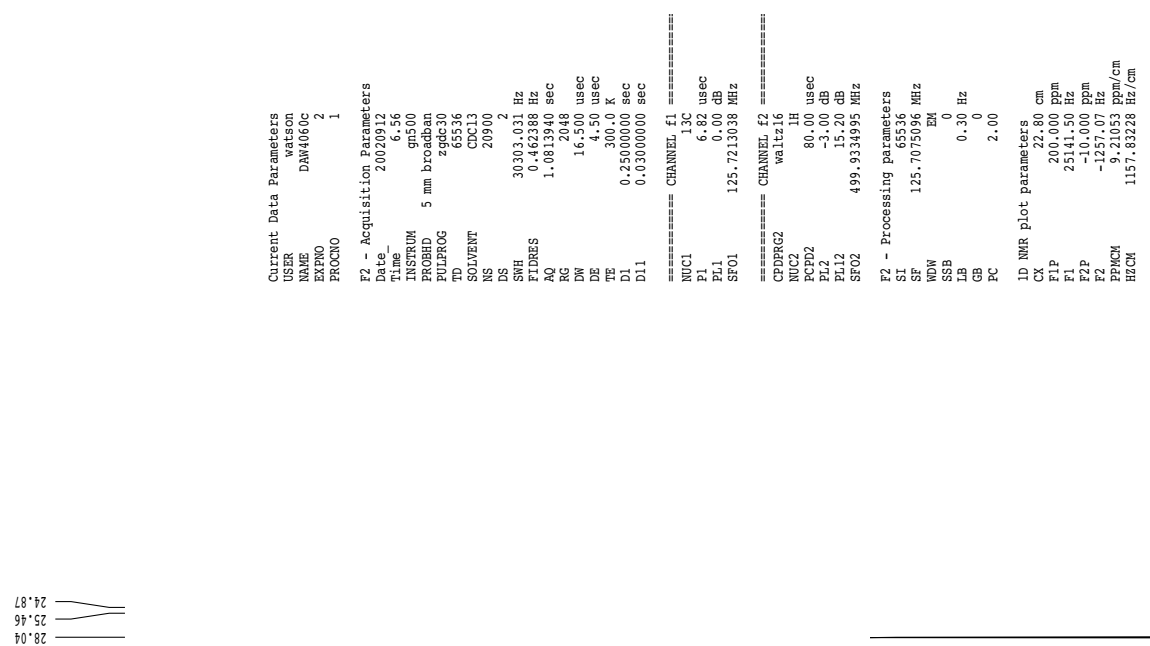

$9 L^{\prime} 25$

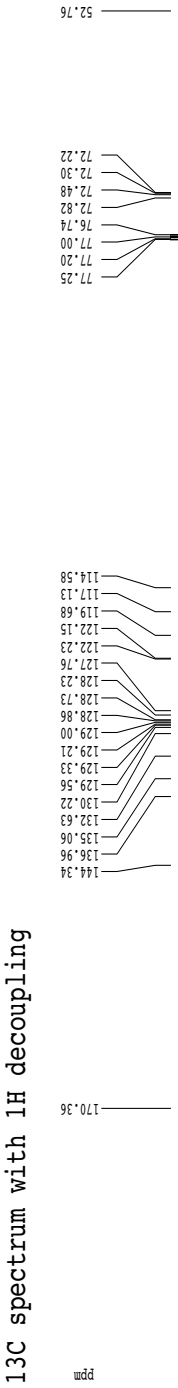

${ }^{8 r^{\prime} \cdot z L}=$

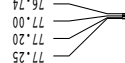

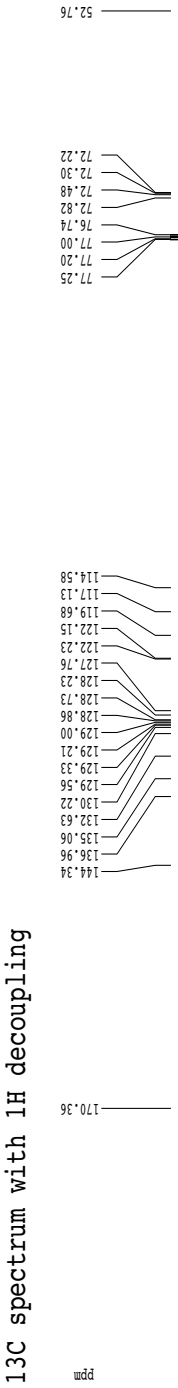

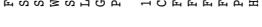

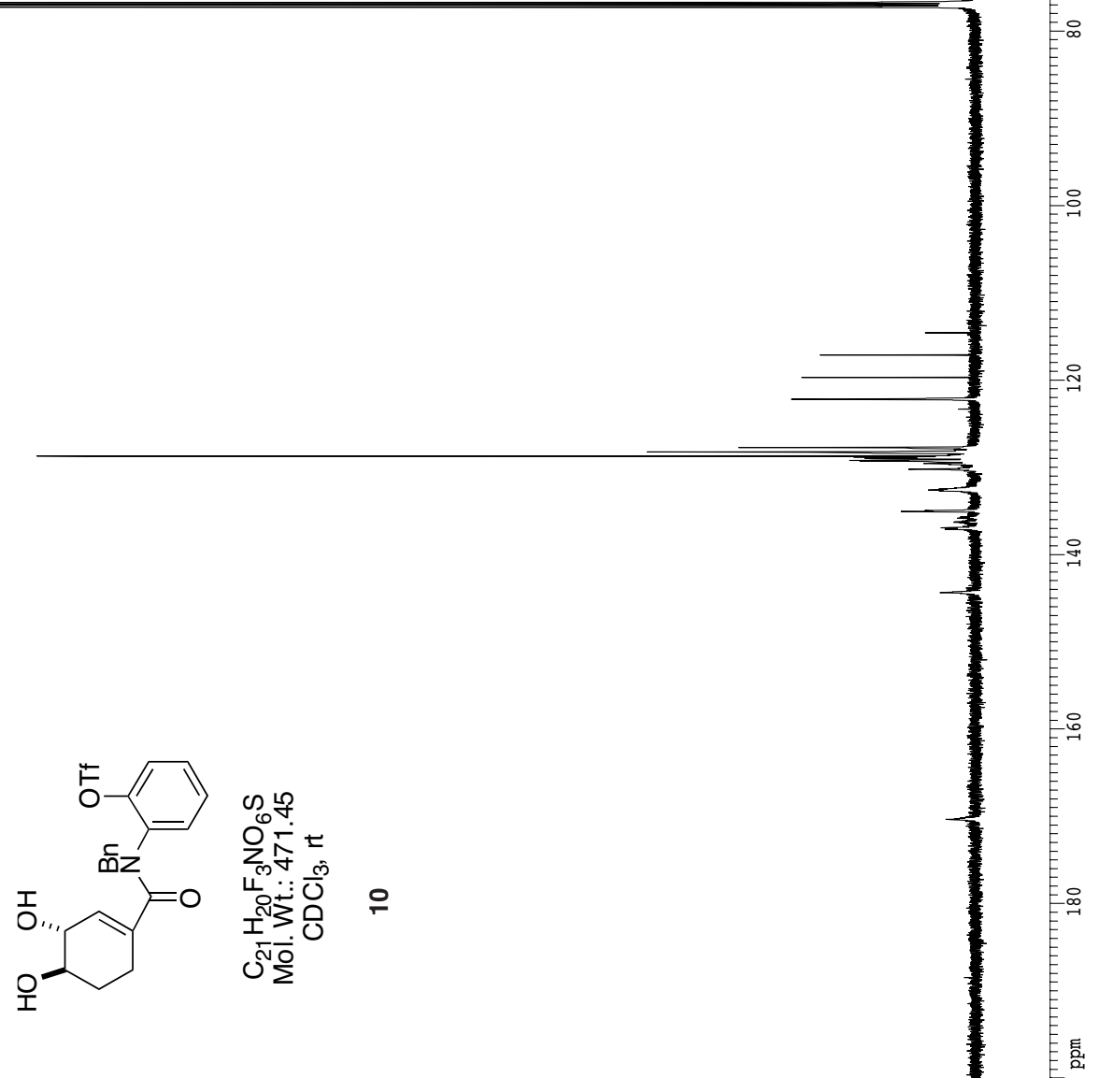




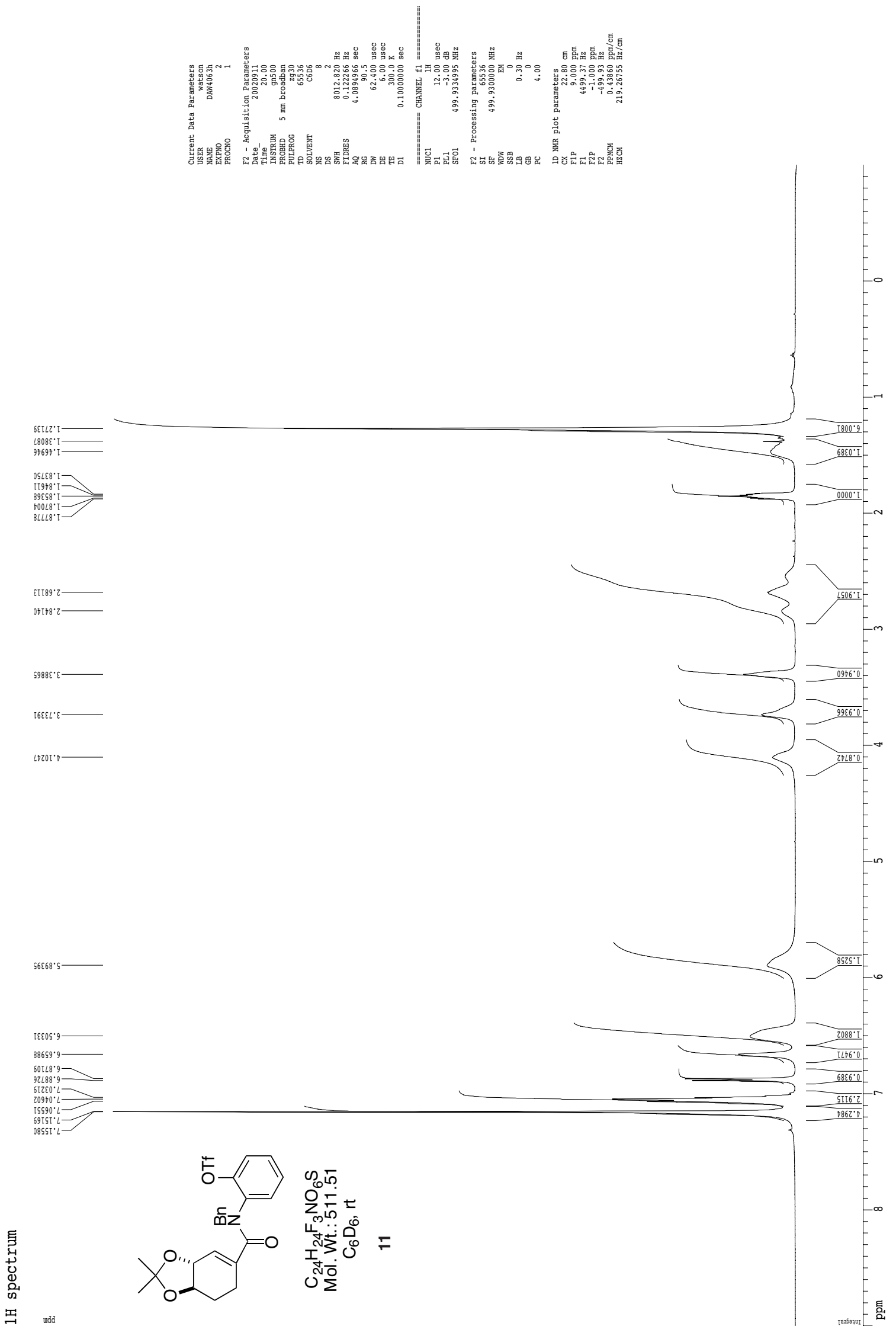




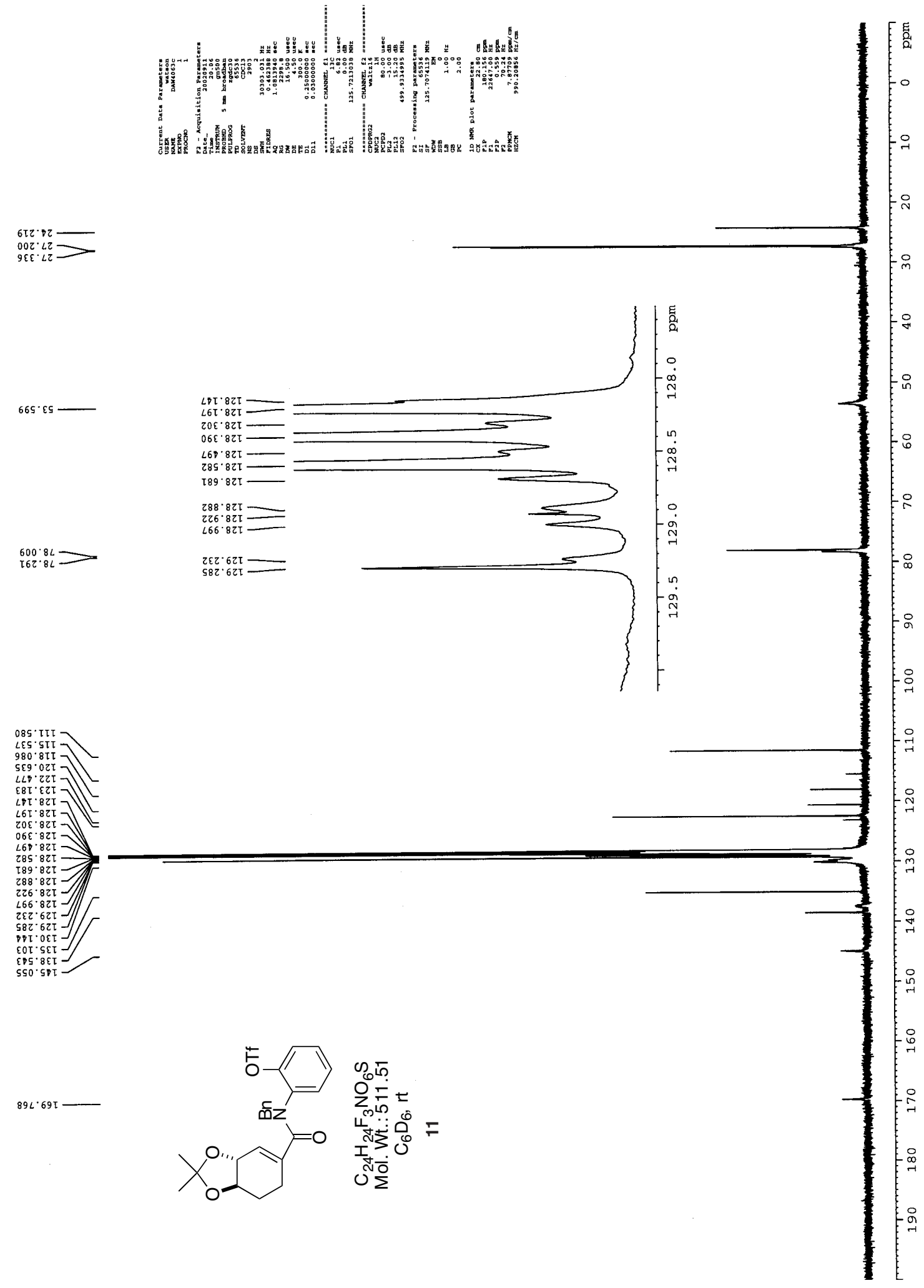


Supporting Information Overman and Watson
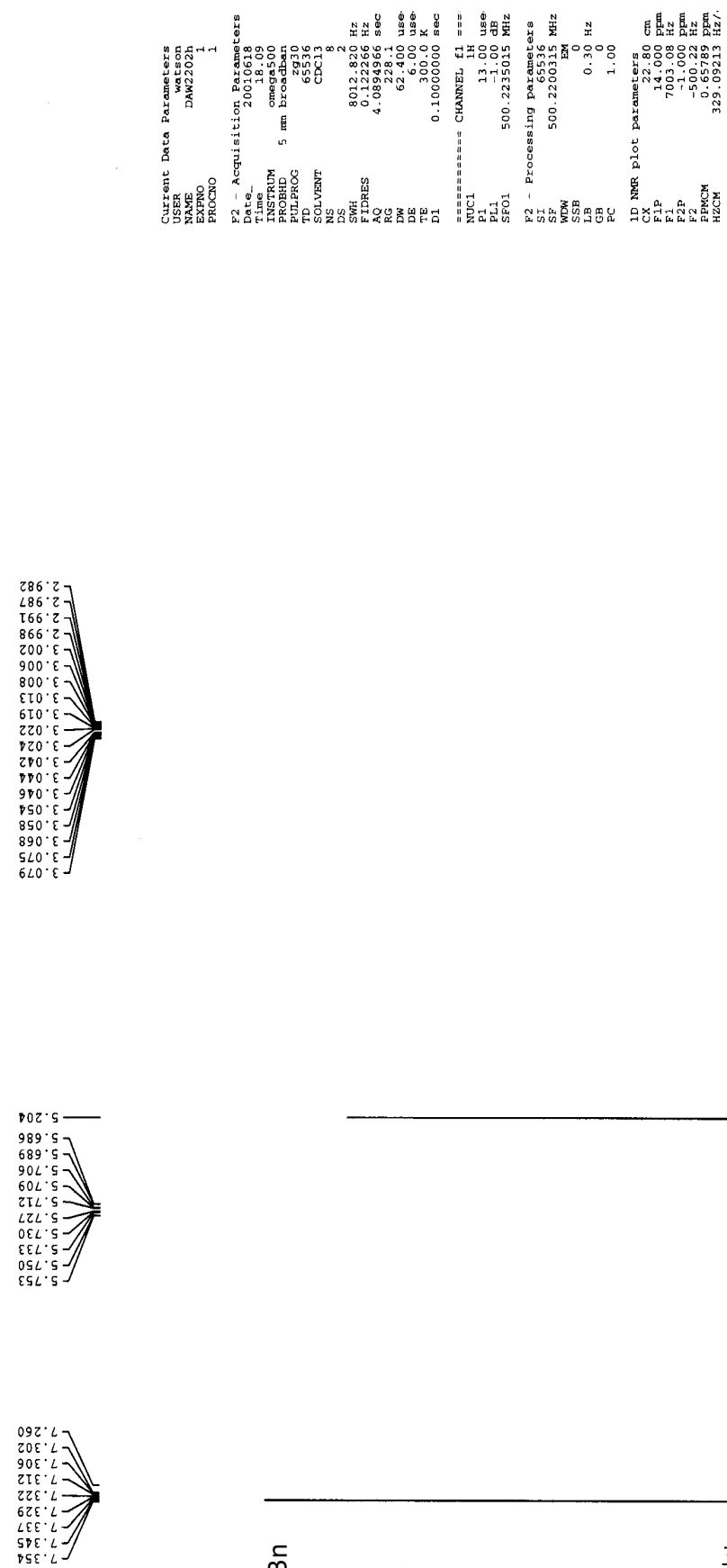

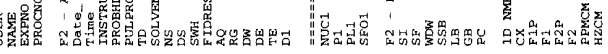

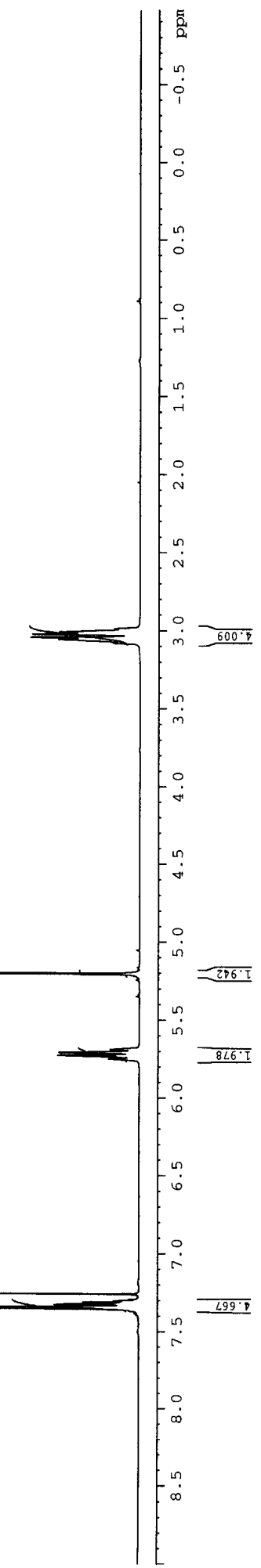



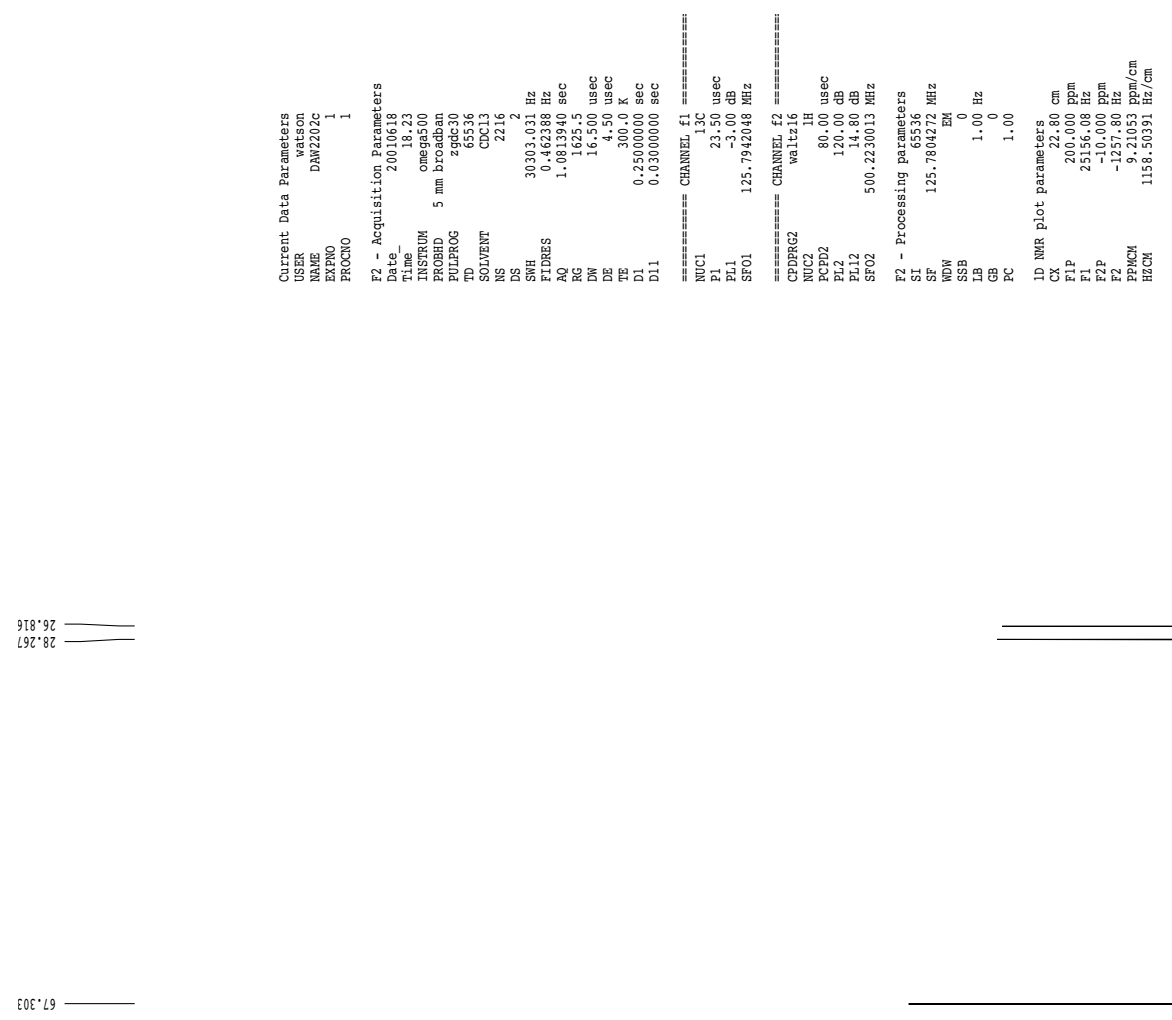

$97 L \cdot 9 L$
$000 \cdot \angle L$
$09 C^{\circ} \angle L$

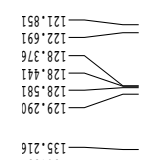

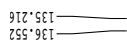
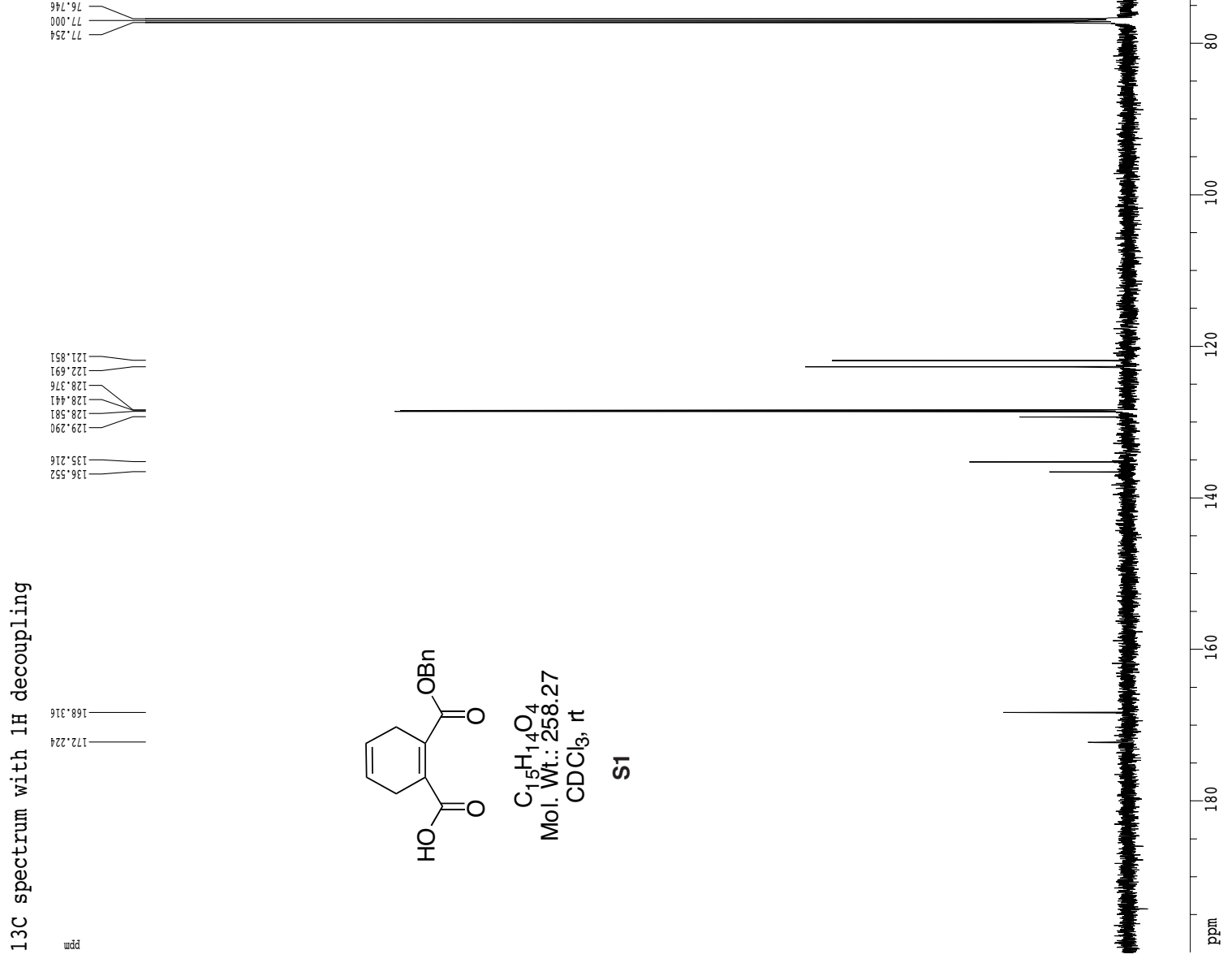

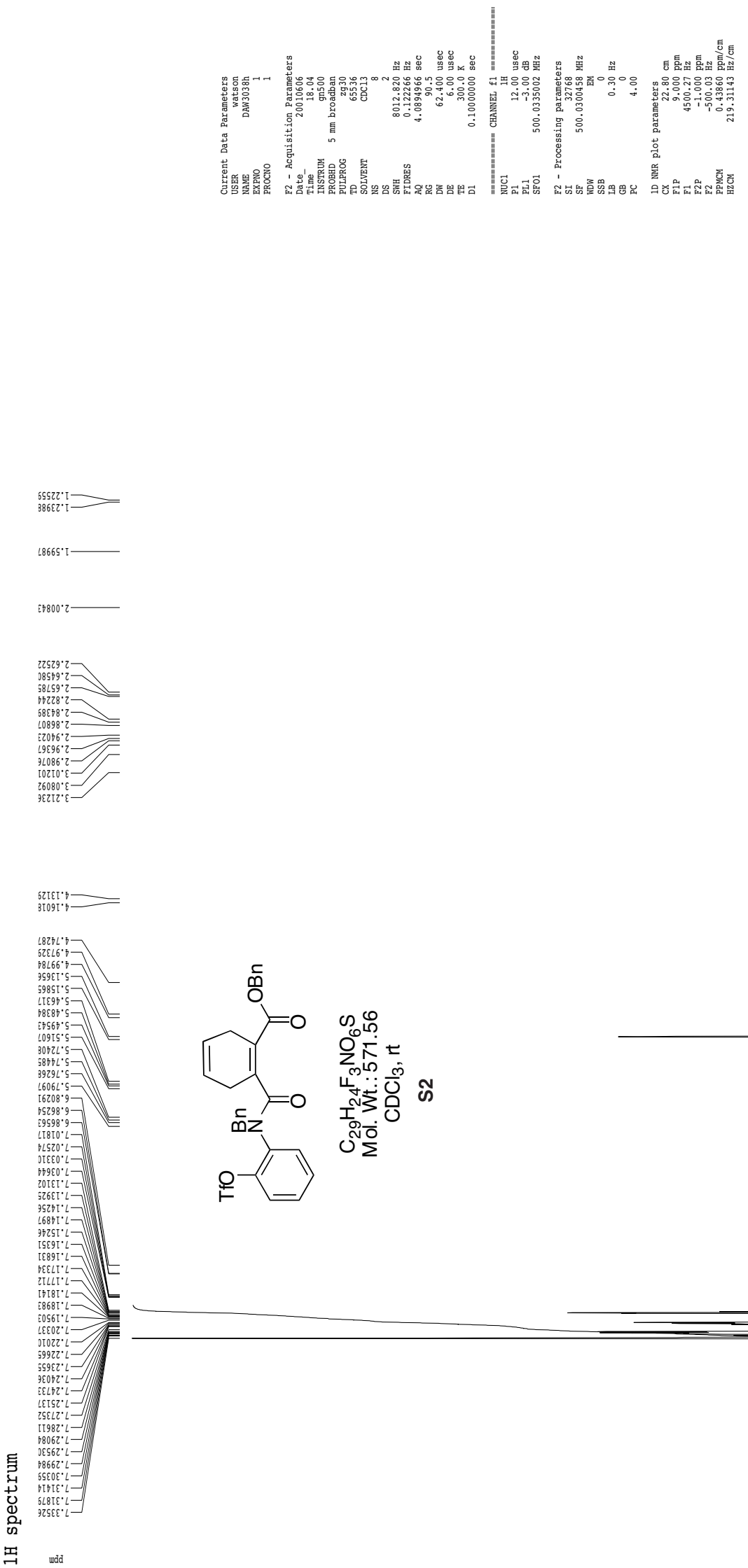

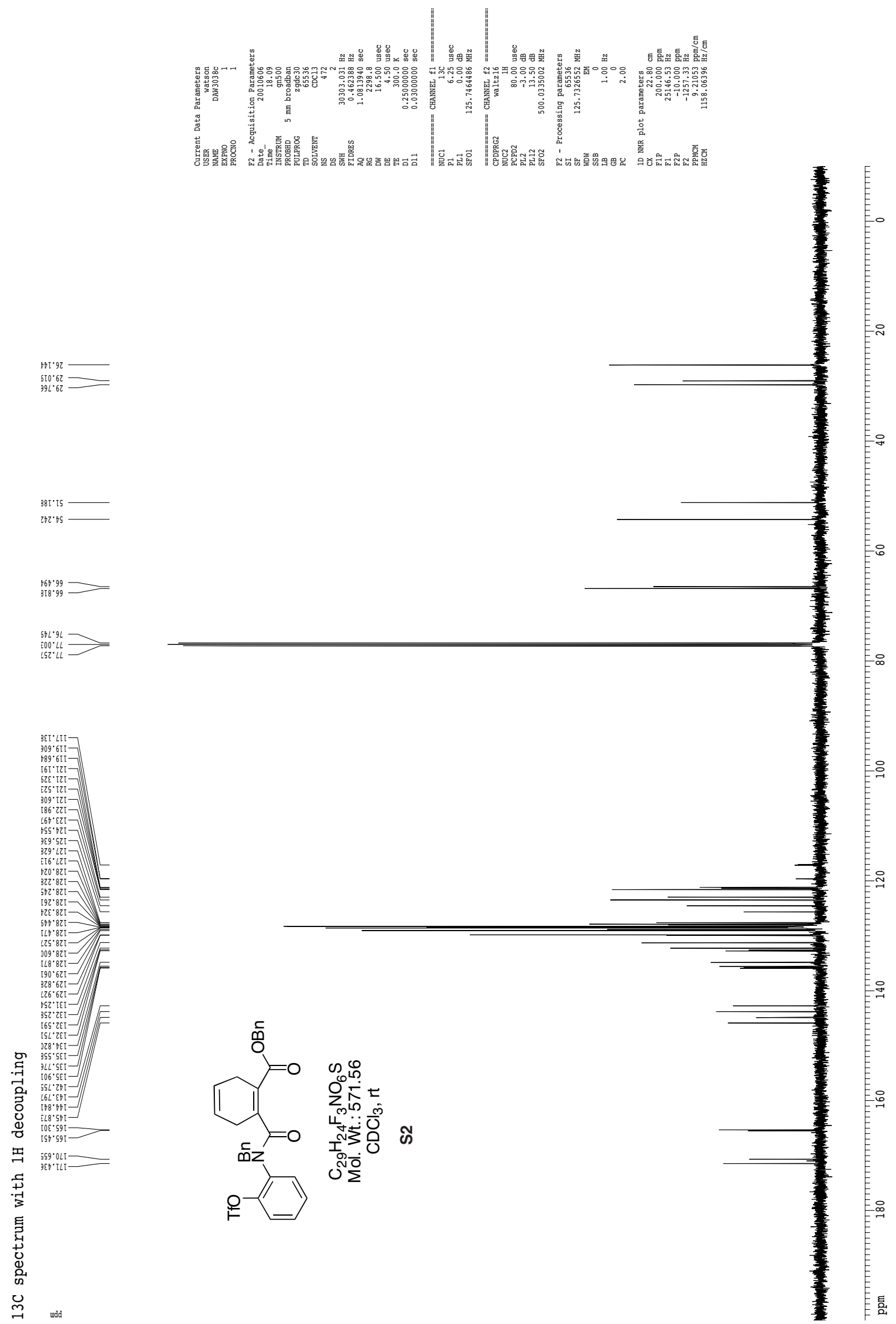
Supporting Information Overman and Watson
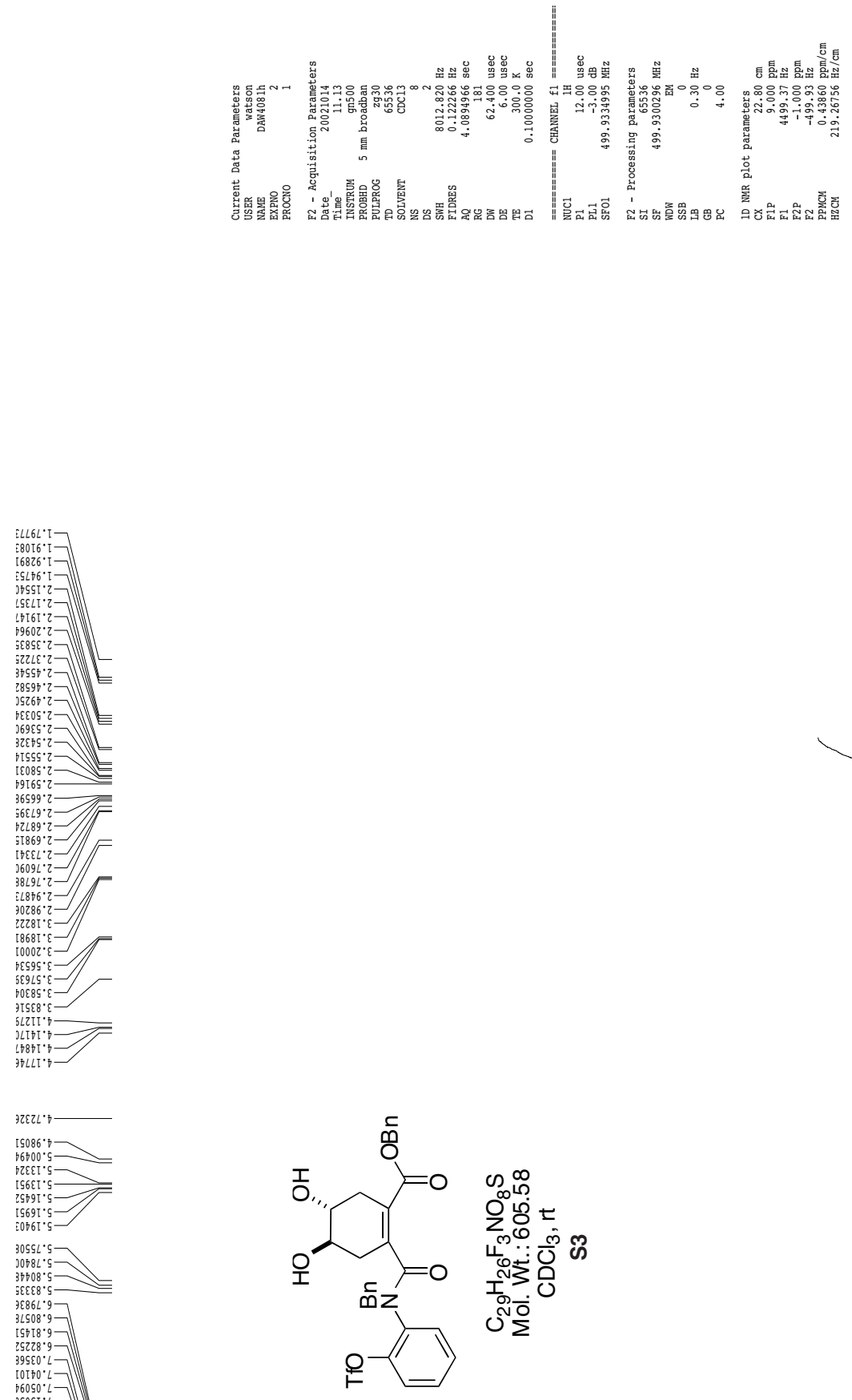

$\left.66500^{\circ} \cdot-7\right]$

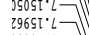

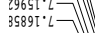

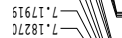

$321280^{\circ} \cdot-$

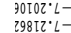

$39272 \cdot 6$

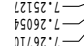

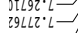

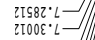

:8800: $2-$

: $\operatorname{LLIE}: L-$

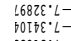

: $88660^{\circ}-2$

$366 \varepsilon^{\circ}$

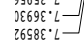

udd

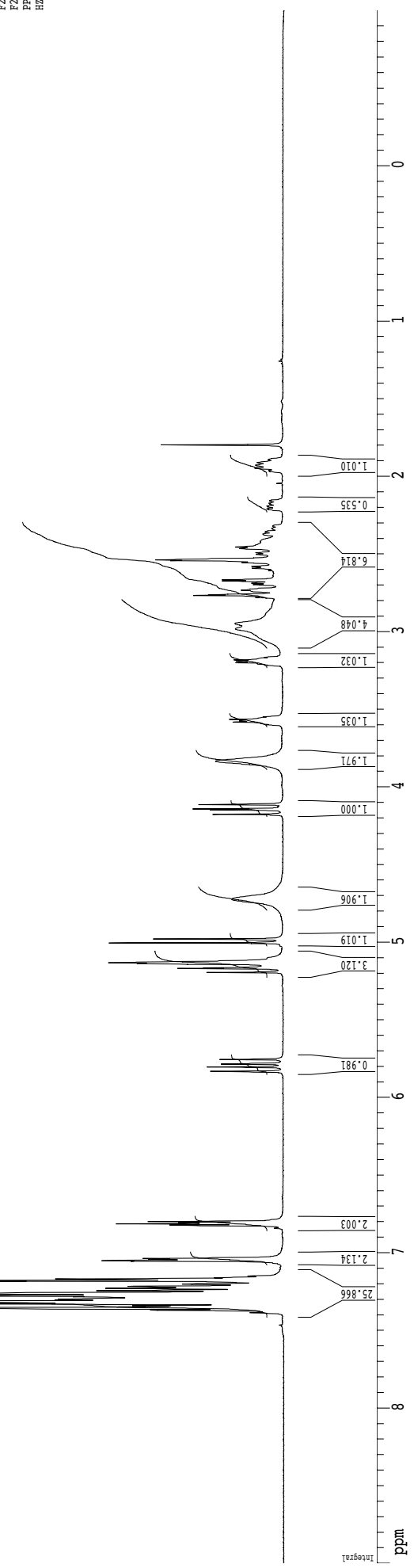


Supporting Information Overman and Watson
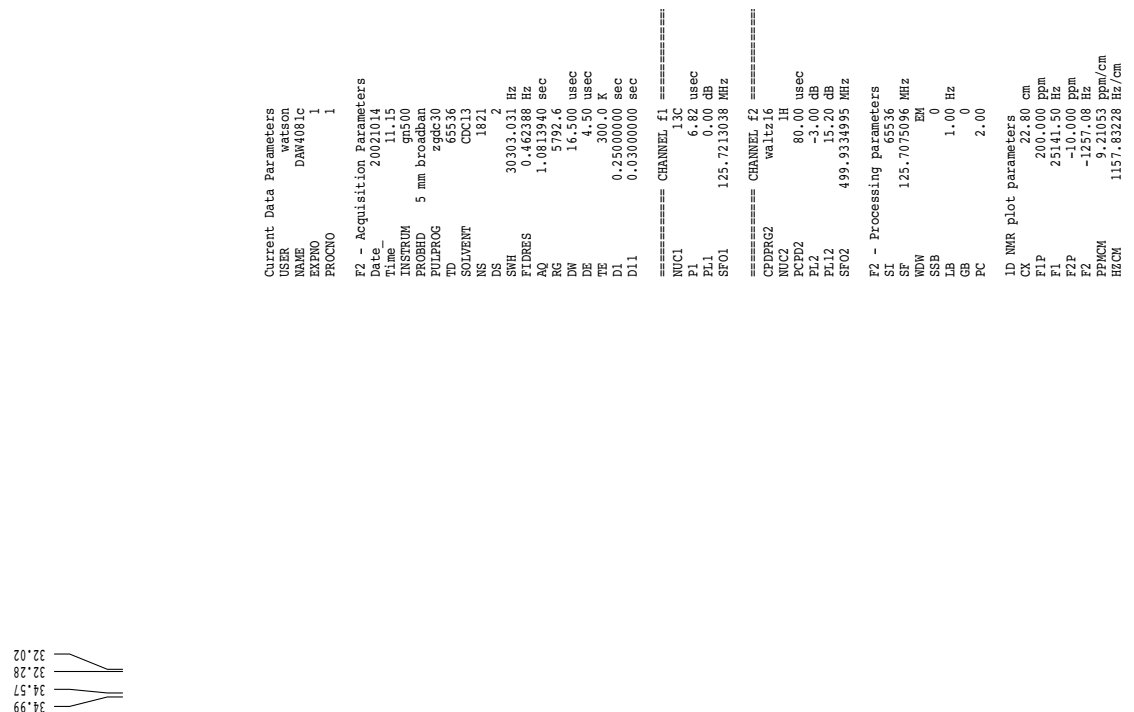

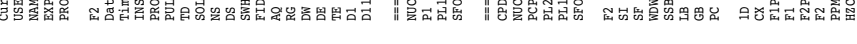
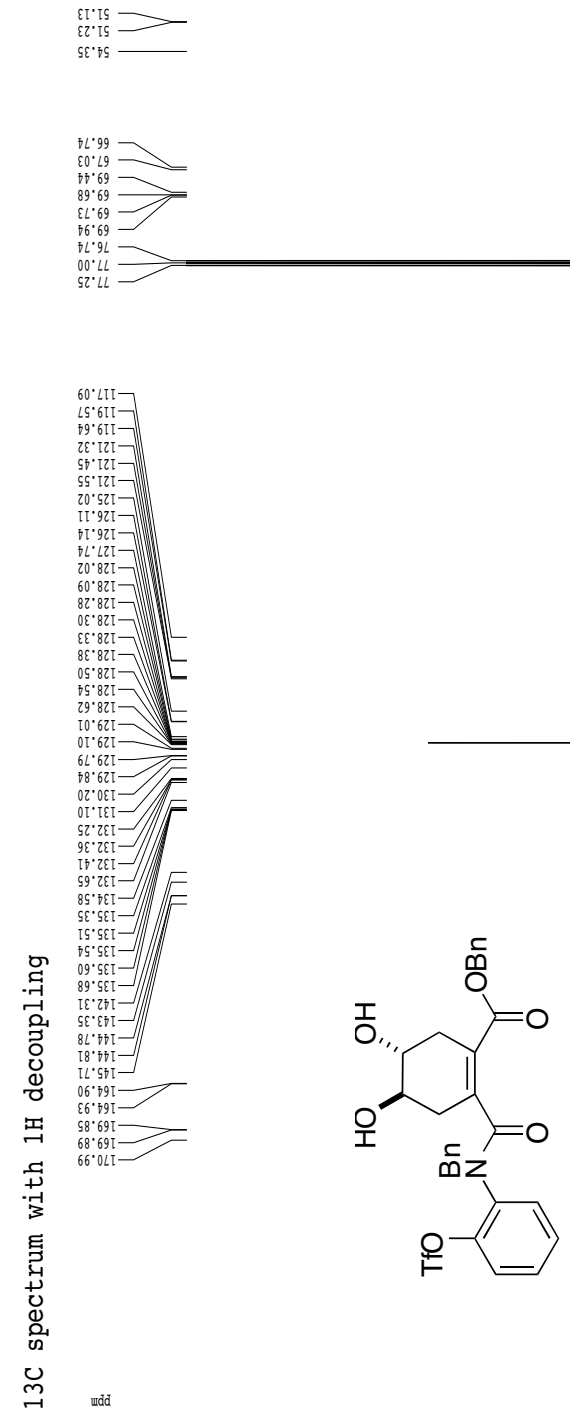

$\infty_{\infty}^{\infty} \infty$

$\sum_{0}^{\infty} \overbrace{0}^{\infty} \div$

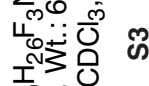

ํํำ 
Supporting Information Overman and Watson
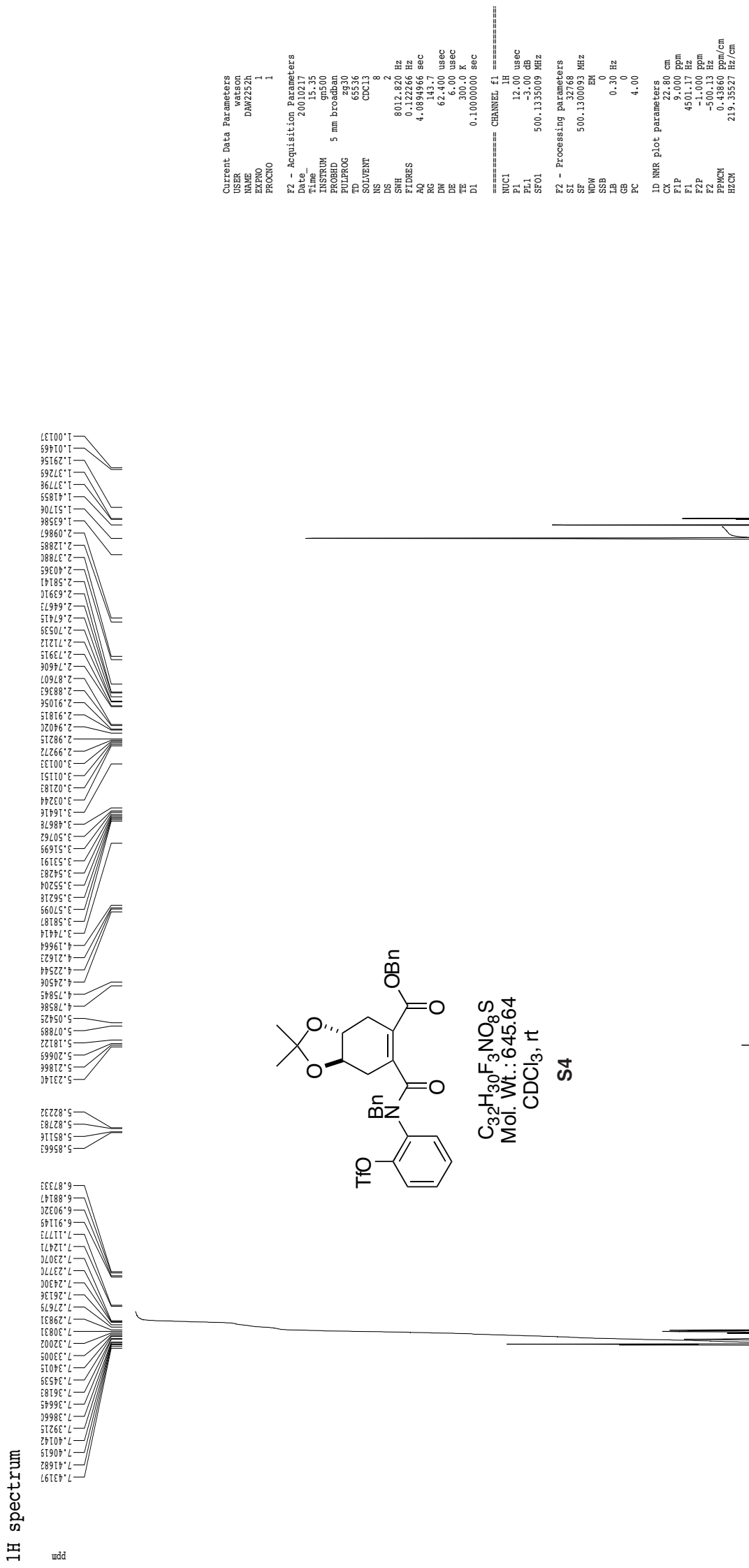

udd 

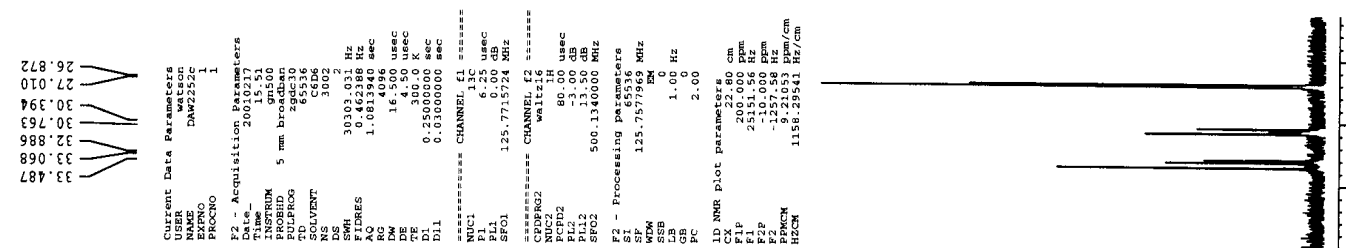

$892 \cdot 15$

$\angle D O D$

98.99
88.99
18.99

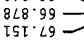

$\varepsilon\llcorner\varepsilon \cdot S L$

$197.5 L$
$629.5 L$ 6.52

698.92

$9 \varepsilon 2 \cdot 9 L=$

${ }_{\mathrm{Ss}}^{20 . \mathrm{LL}}$

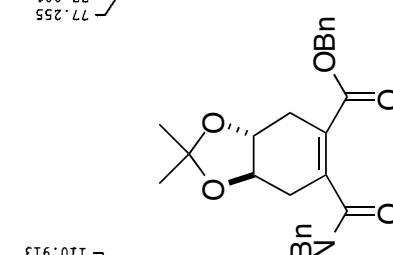

$\varepsilon \tau 6^{\circ} \cdot 0 t \tau$
$690^{\circ} \tau \tau \tau$
$96 \tau \cdot \tau \tau \tau$

$96 \tau \cdot \tau[\tau]$

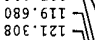

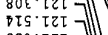

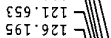

IEr $\angle 2 \tau]$

SSL. LZT

$980.82 \tau]$

$\left.\begin{array}{ccc}\text { TET } 827 \\ \text { STE } 82 \tau\end{array}\right]$

$658.827]$

$20 \%$
$920.82 \tau$

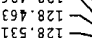

$2 \angle 5.821$

$266.82 \tau$

LT0.6 6 t

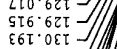

8L6.0ET

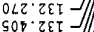

909. Zह Т

$\left.\begin{array}{ccc}8 \nabla c \cdot z \varepsilon \tau \\ \varepsilon 95 \cdot \nabla \varepsilon \tau\end{array}\right]$

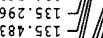

列

669 '

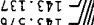

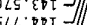

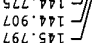

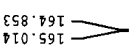

$857.697=$
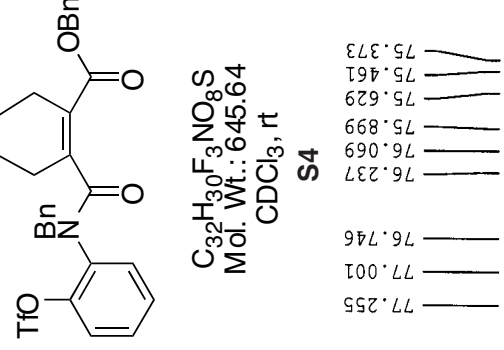

다여

$690^{\circ} 9 L$

U
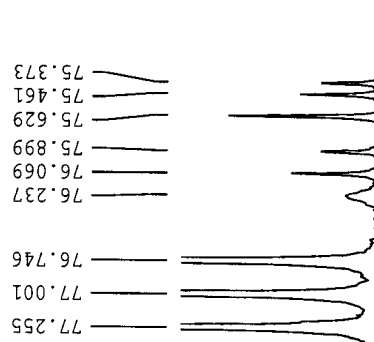

卓 동

ş२
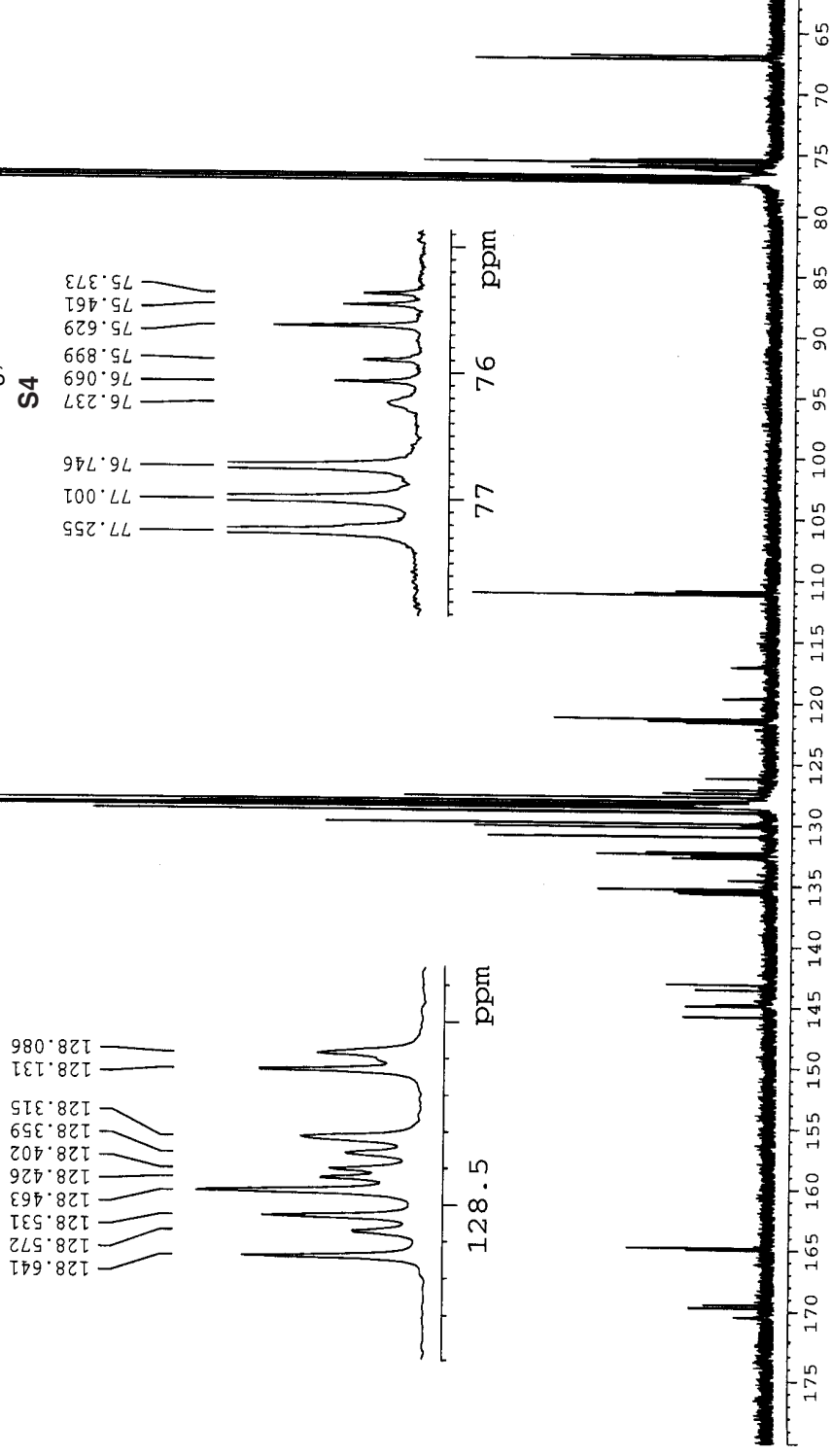

:

:

:

능

윽 

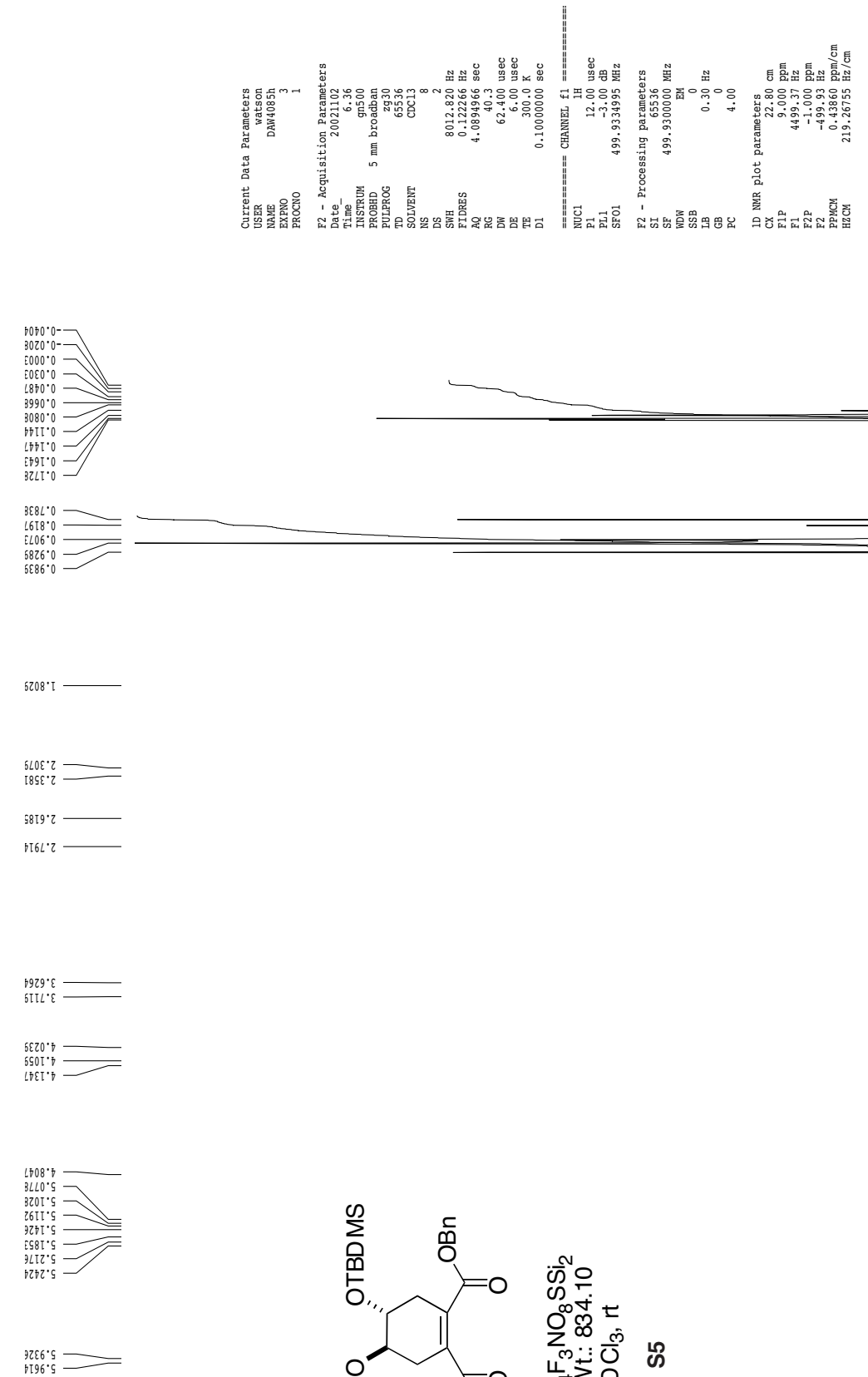
Supporting Information Overman and Watson

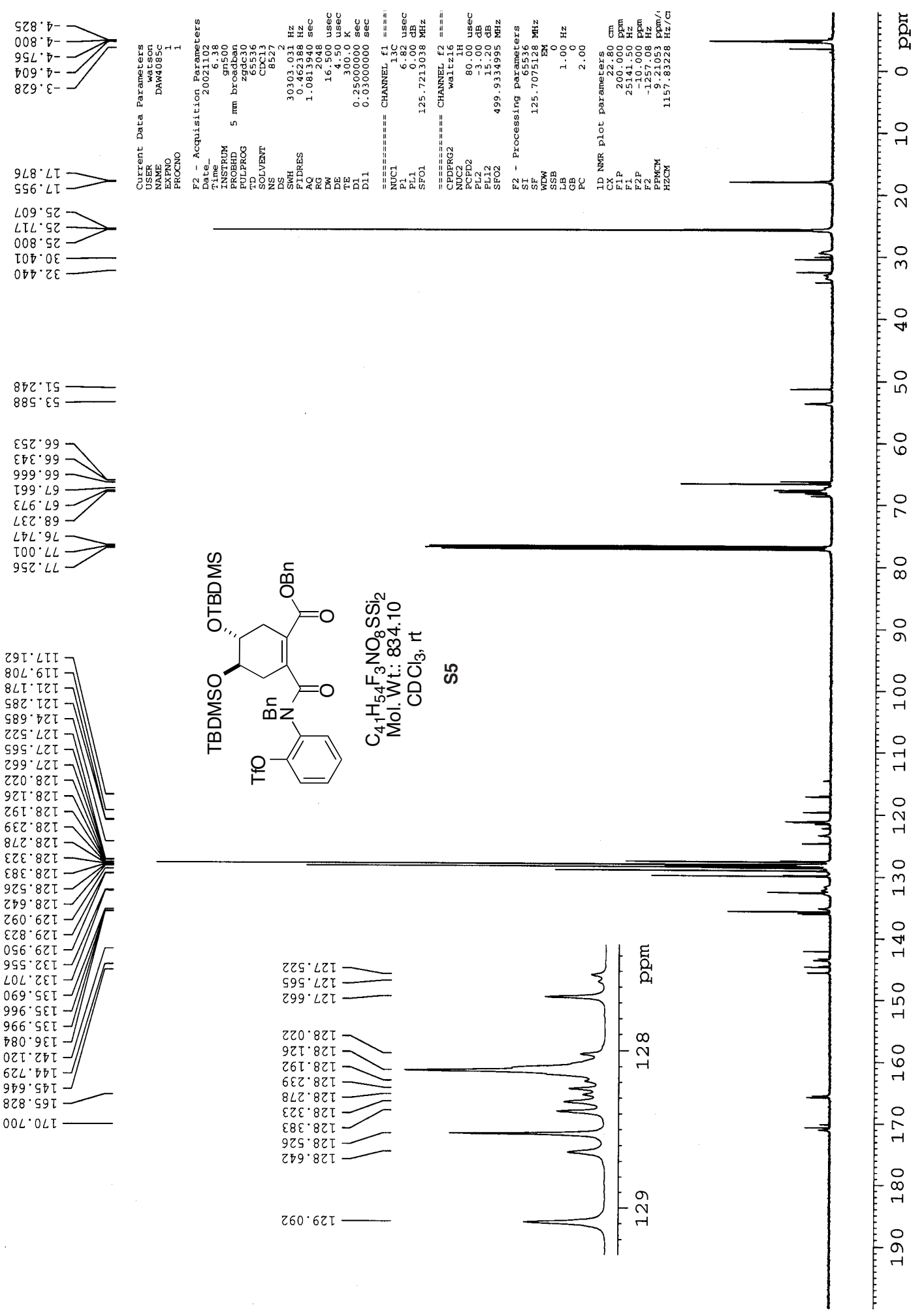




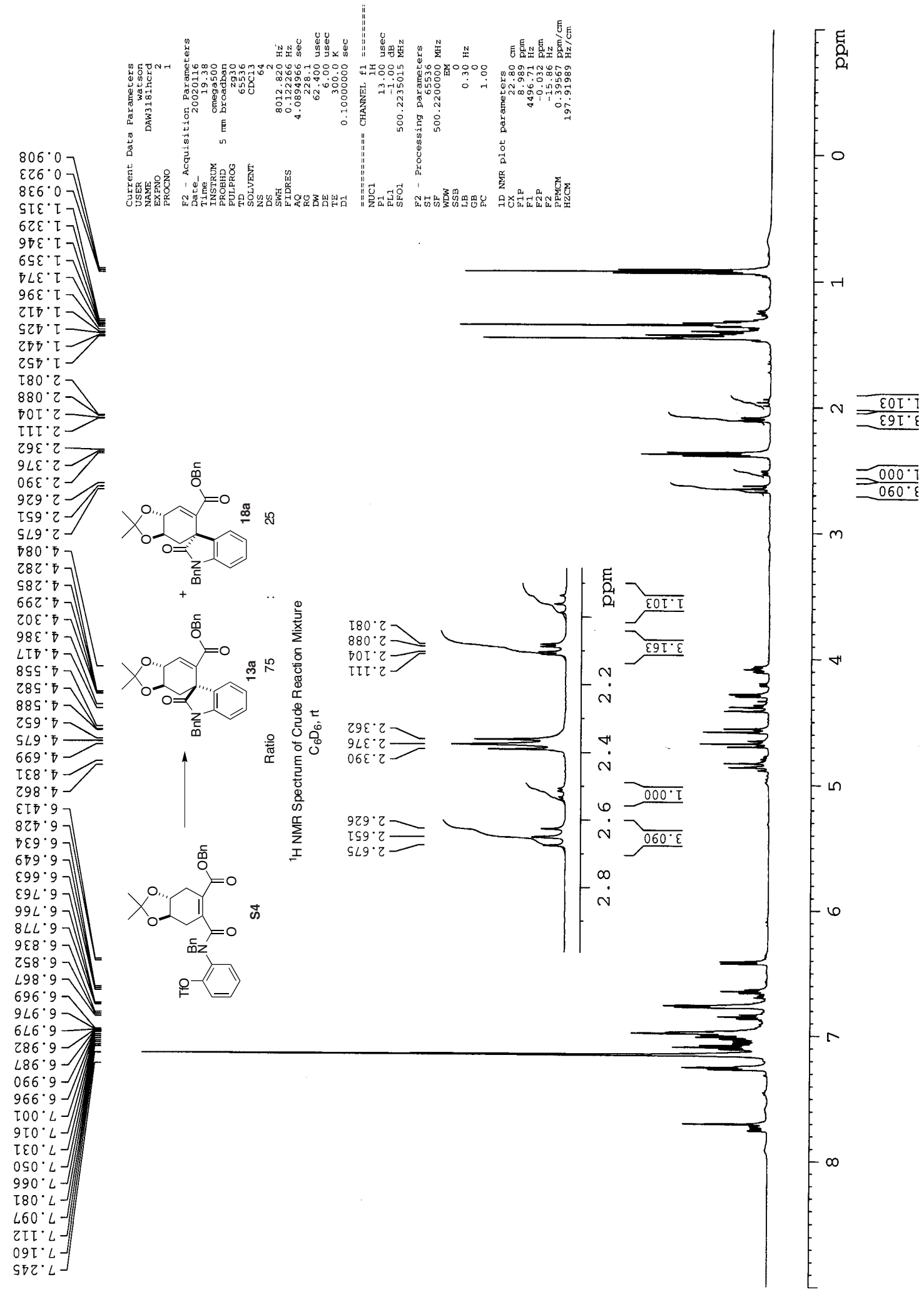



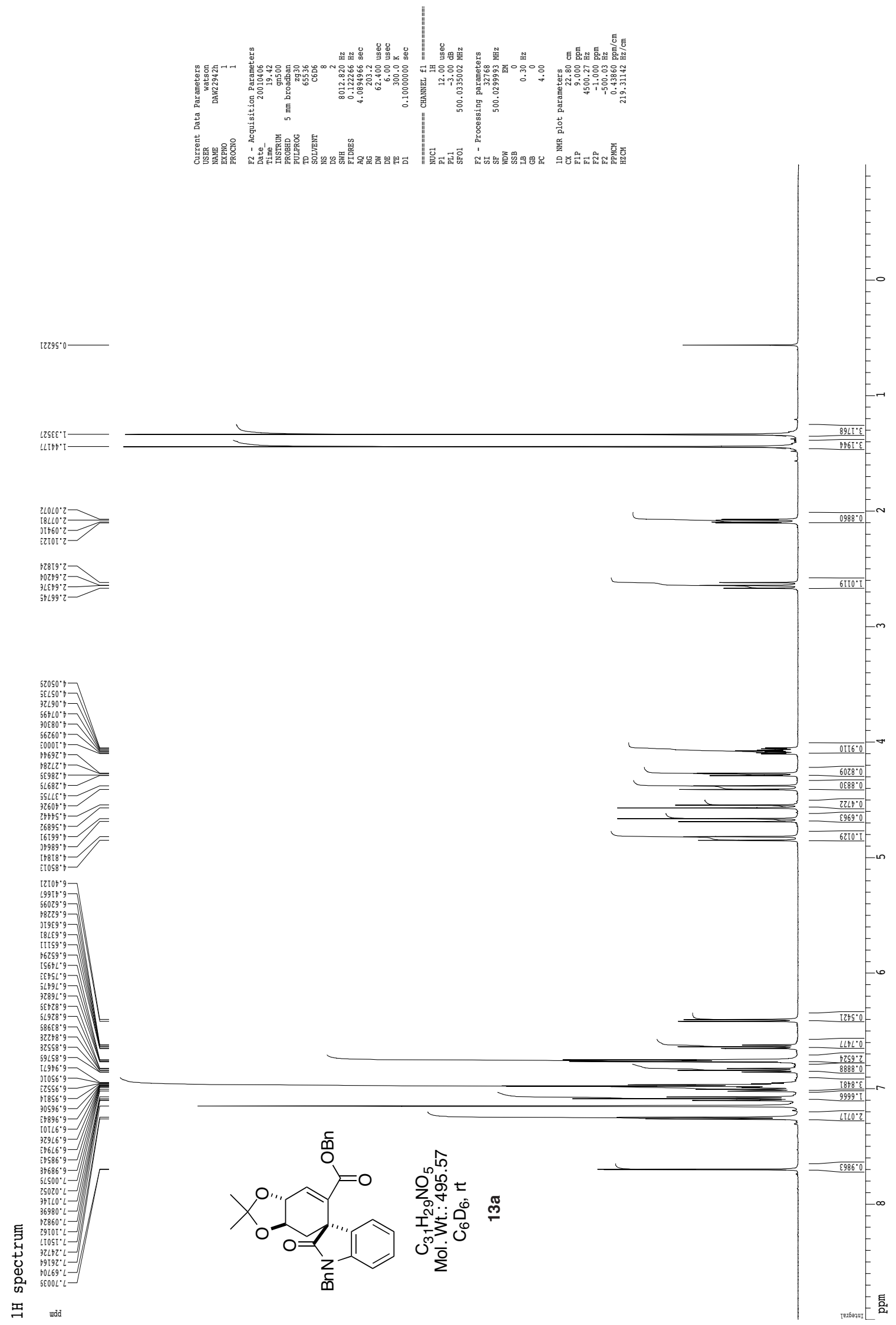
Supporting Information Overman and Watson
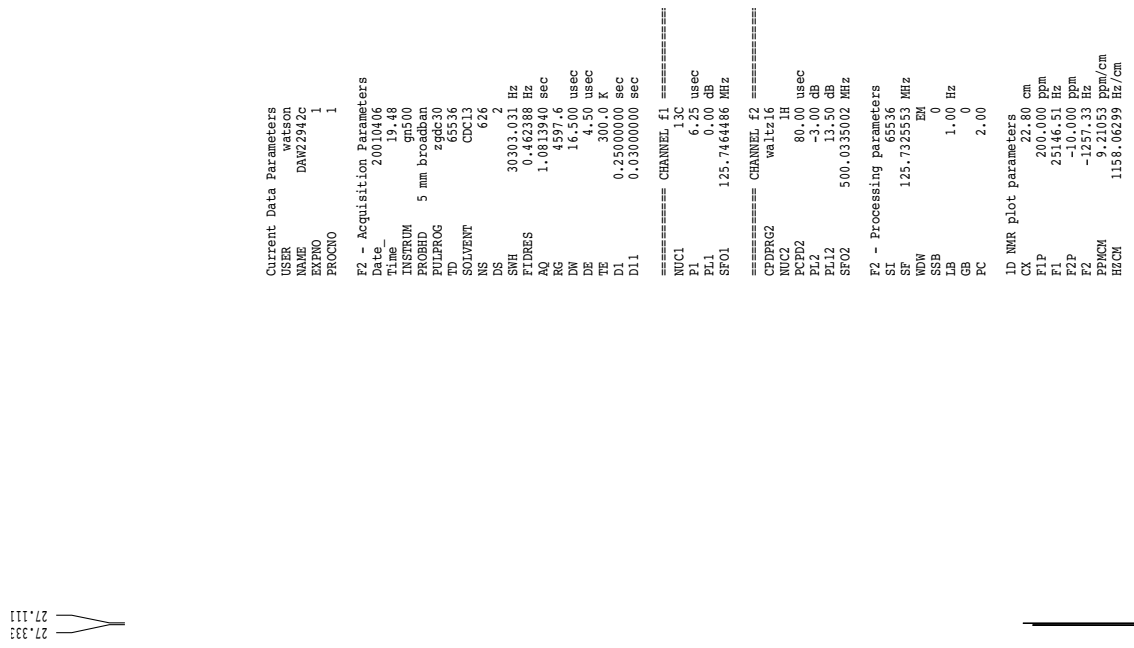

${ }_{\llcorner\varepsilon 9}^{8 \varepsilon}$

$3 b^{\circ} \cdot 6 \mathrm{C}$

${ }^{186} \& \varsigma$

$36 T^{\circ} \angle 9$

$i 6^{\circ} \hbar L$
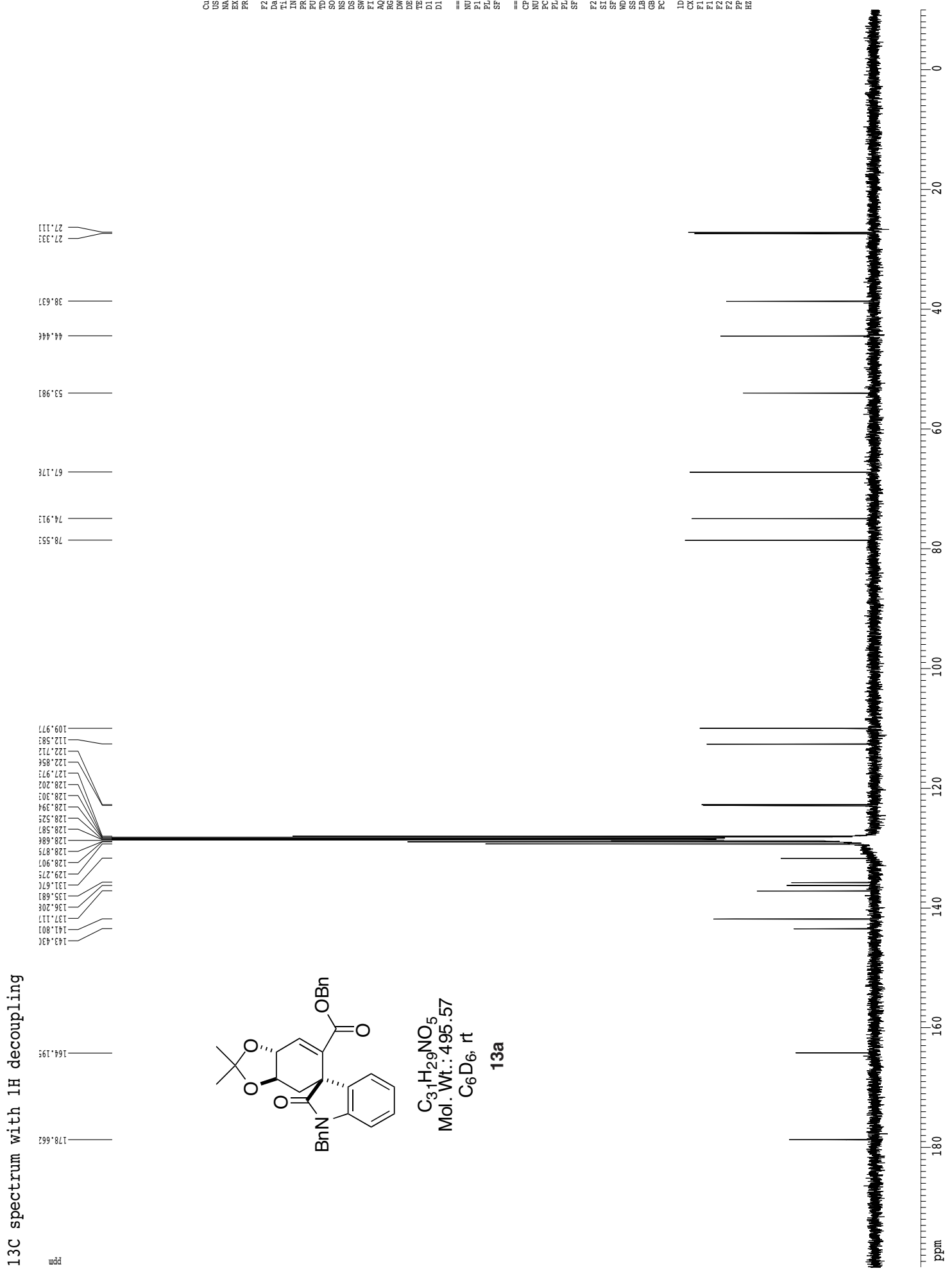

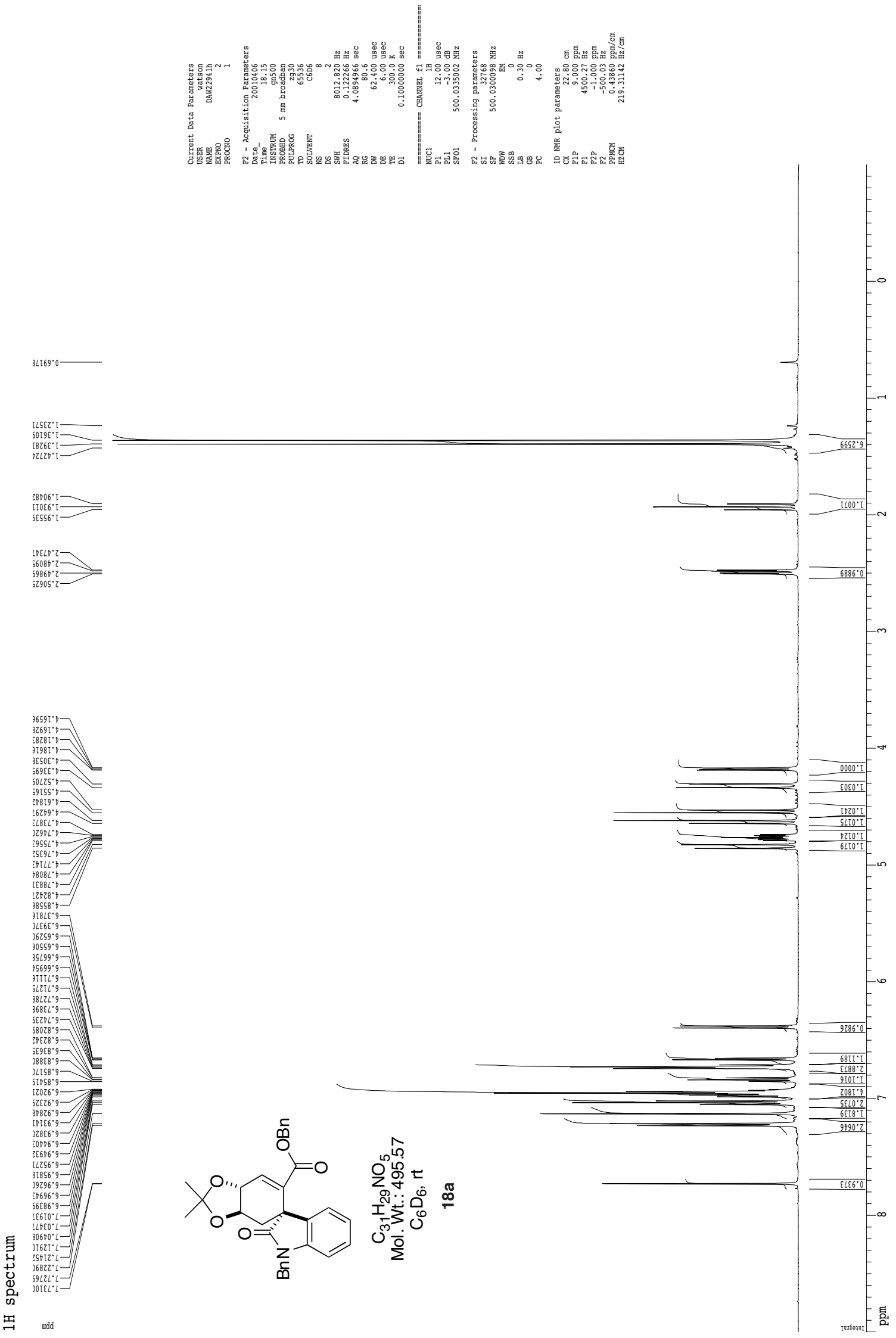

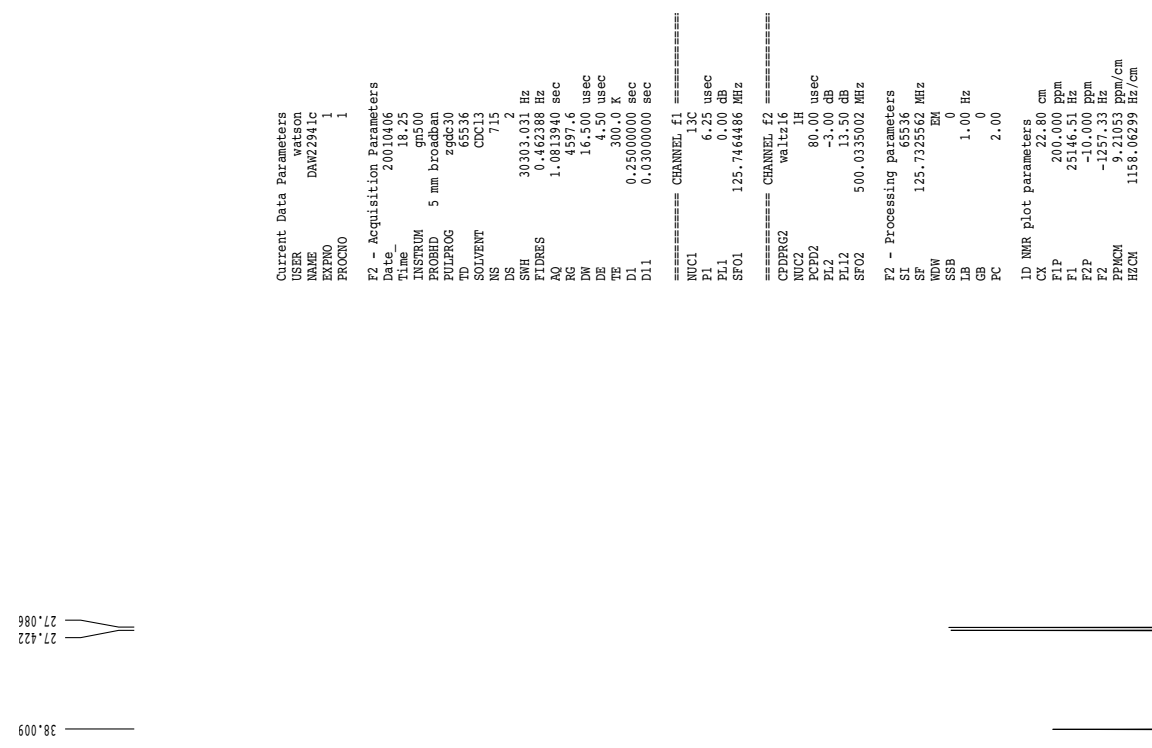

$\forall 6 t^{\circ}+6$

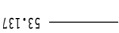

$202 \cdot 19$

$\operatorname{tic} * b L$

$\varepsilon \varepsilon L^{\circ} 8 L$

${ }^{2} 88^{\circ} 60 \mathrm{I}$
$\mathrm{I}^{2} \mathrm{2II}$

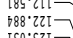

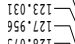

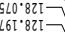

$\left.6 \tau^{\circ} 8217\right]$

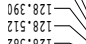

${ }_{289}^{889828}=$

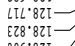

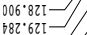

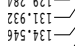

ILLT' 9EI -

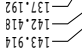
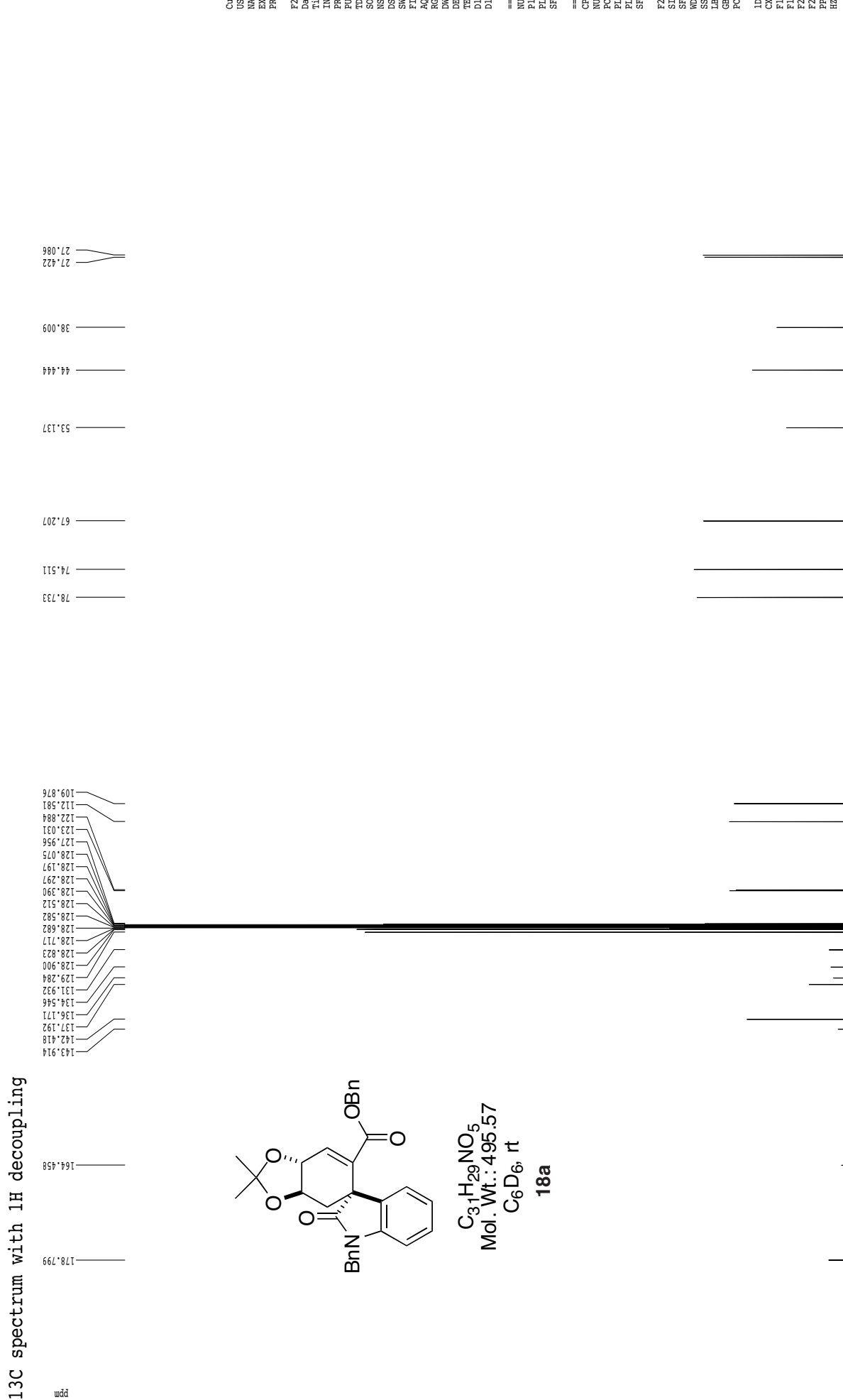

우

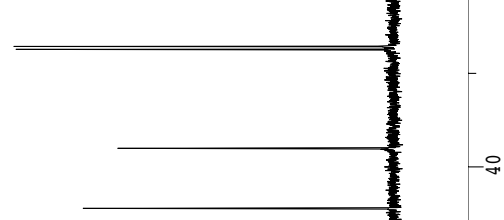

- 운
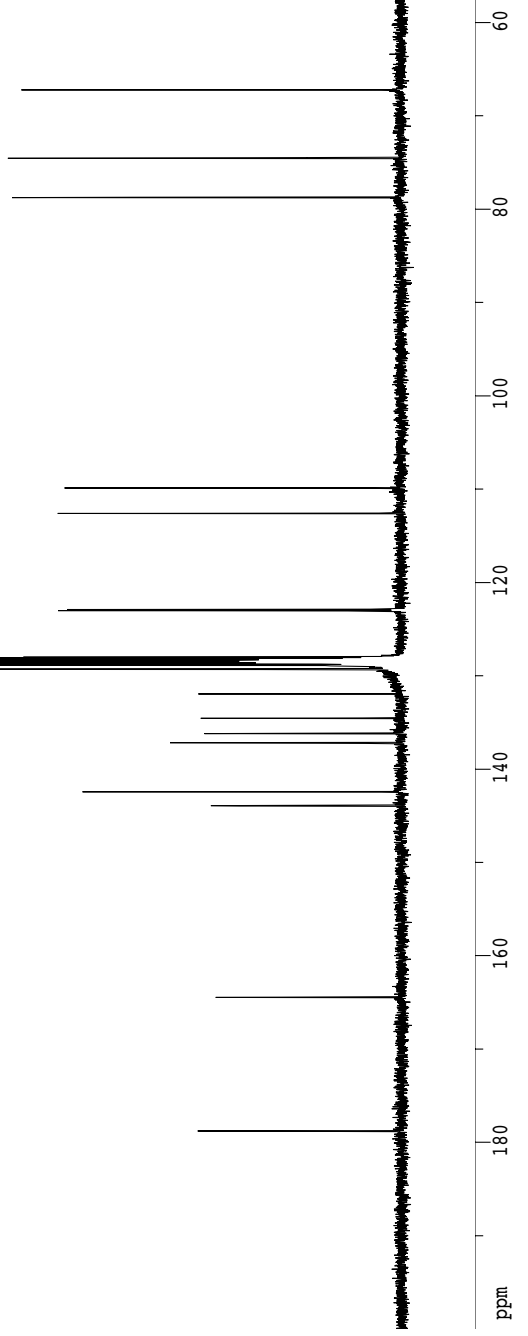


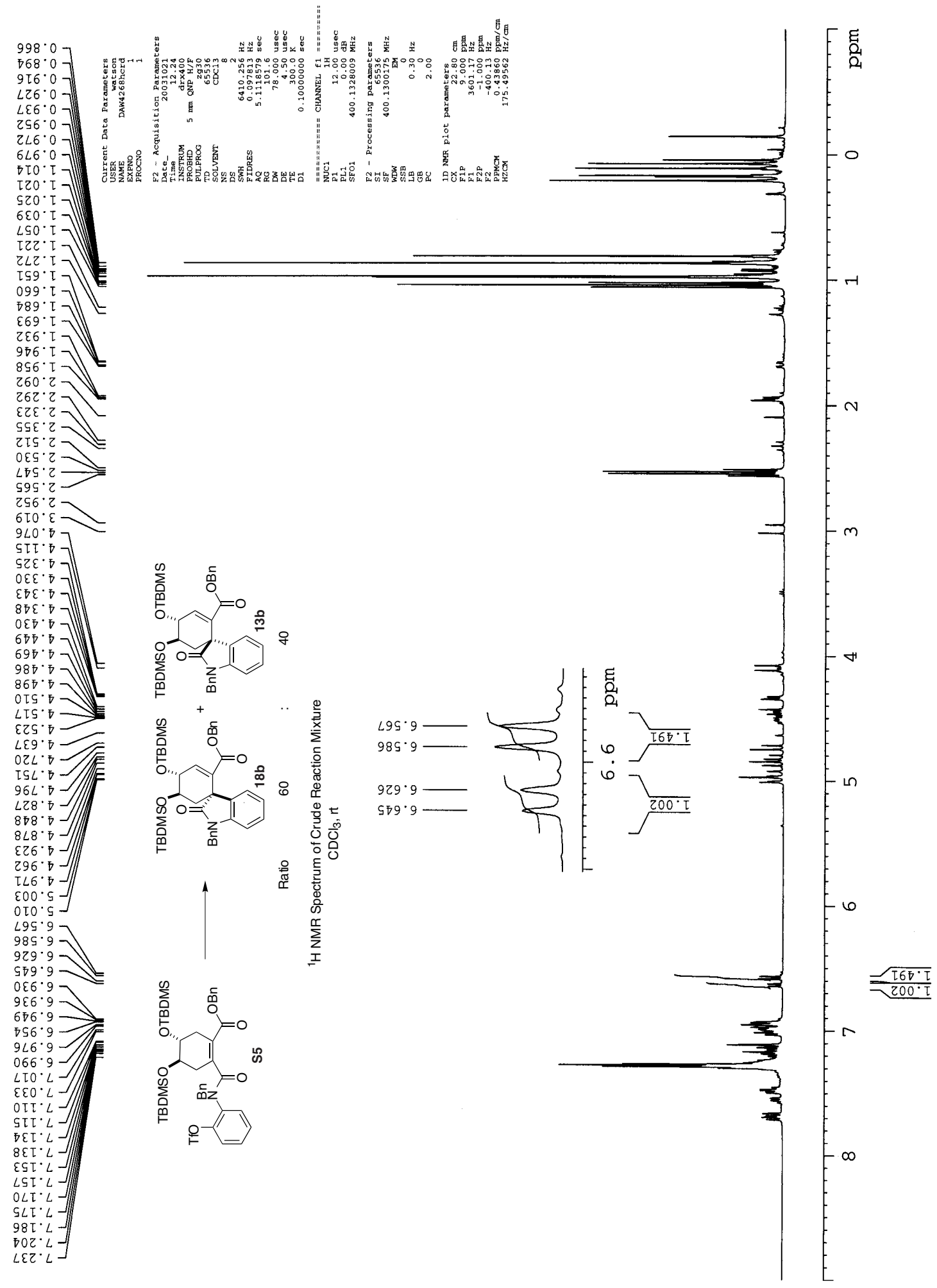




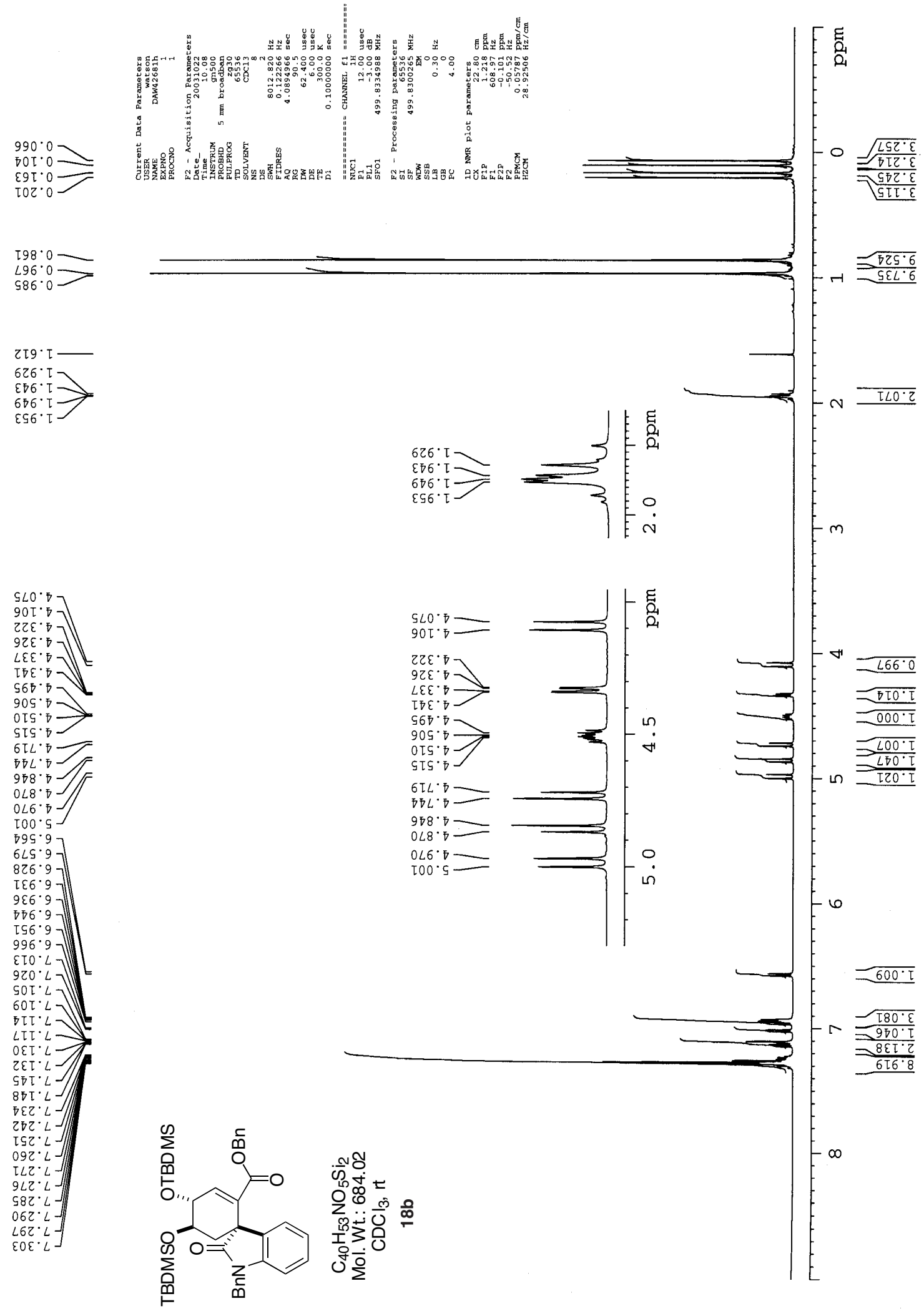



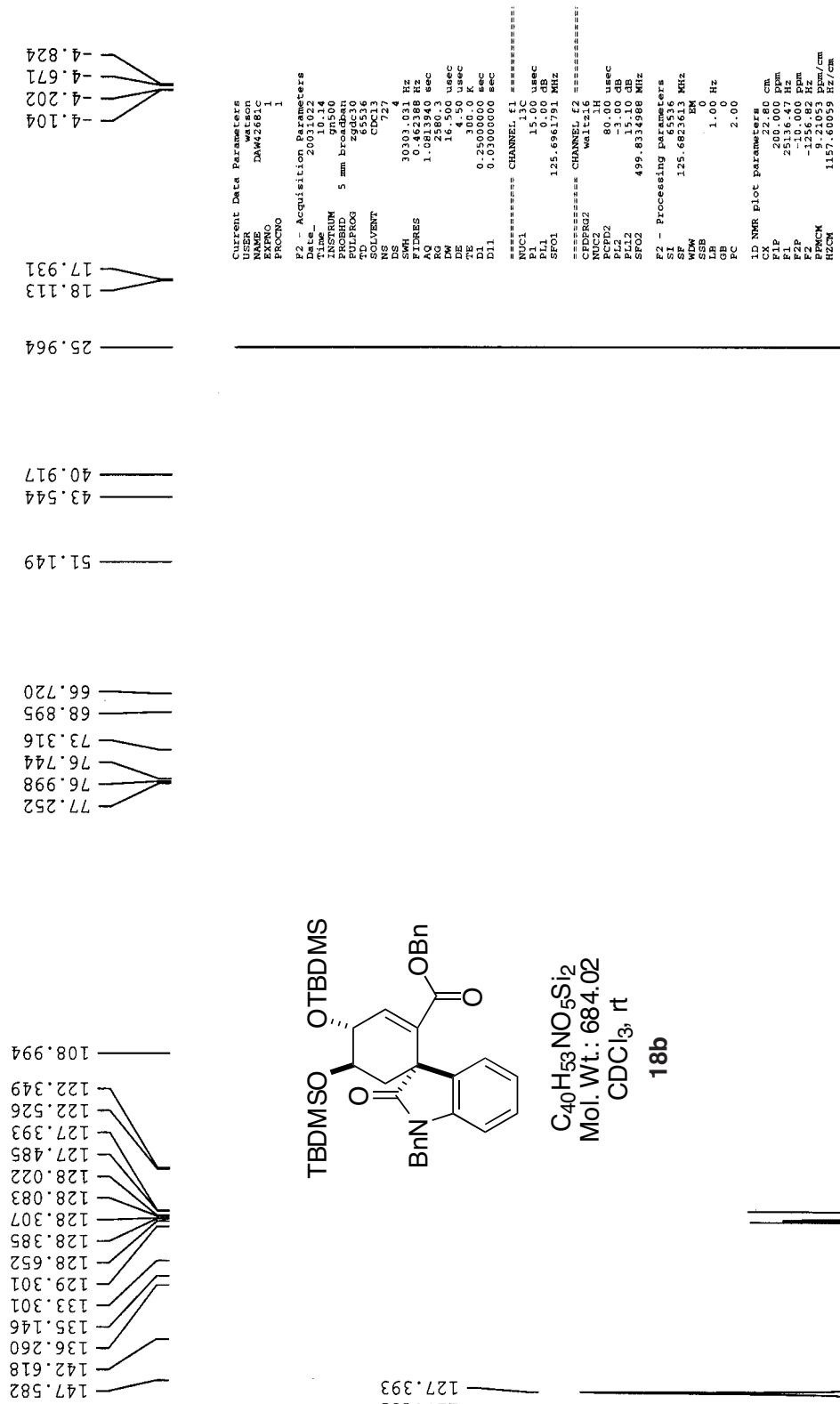

Z6L・79I -

$988^{\circ} L L I-$
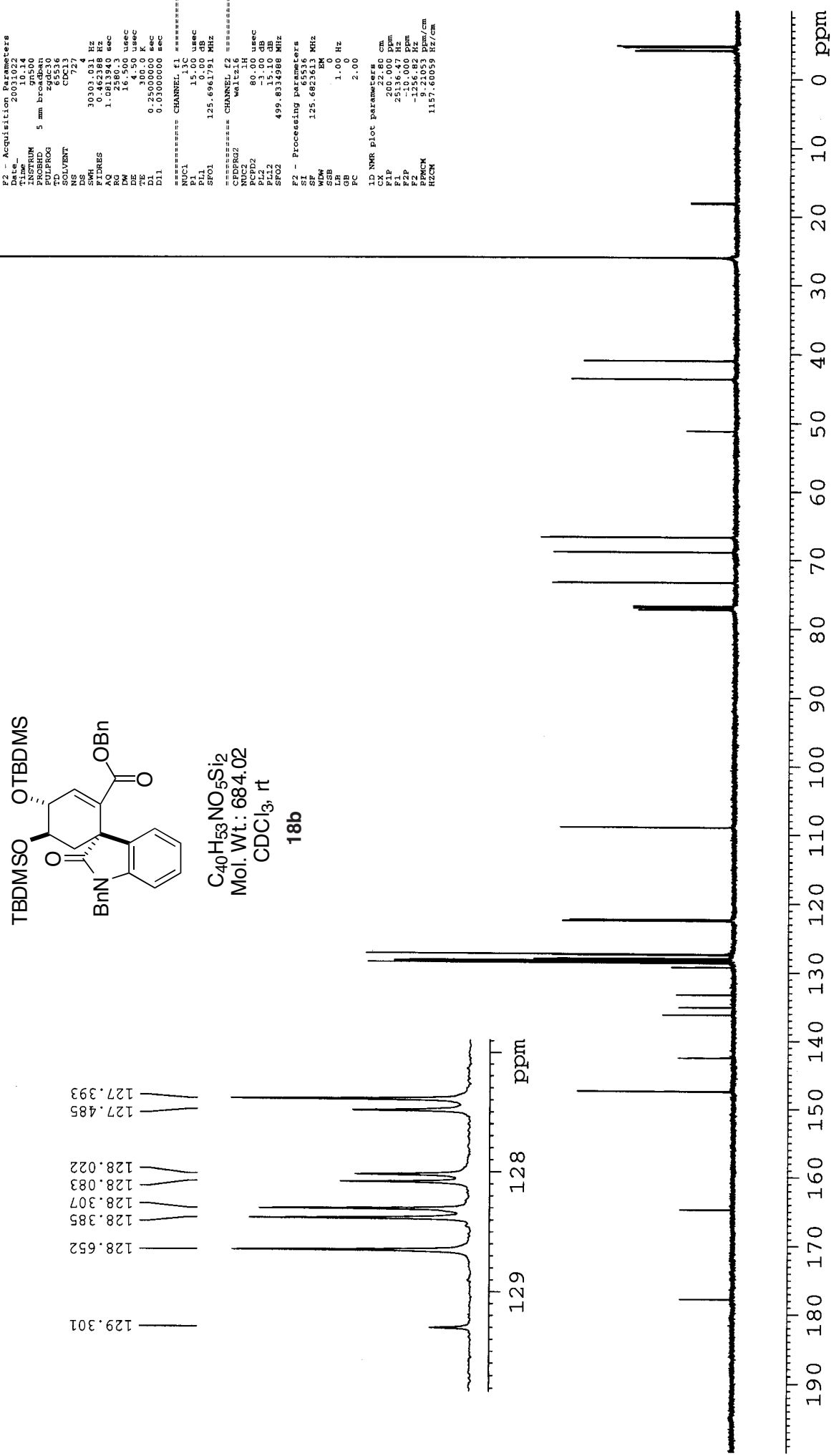


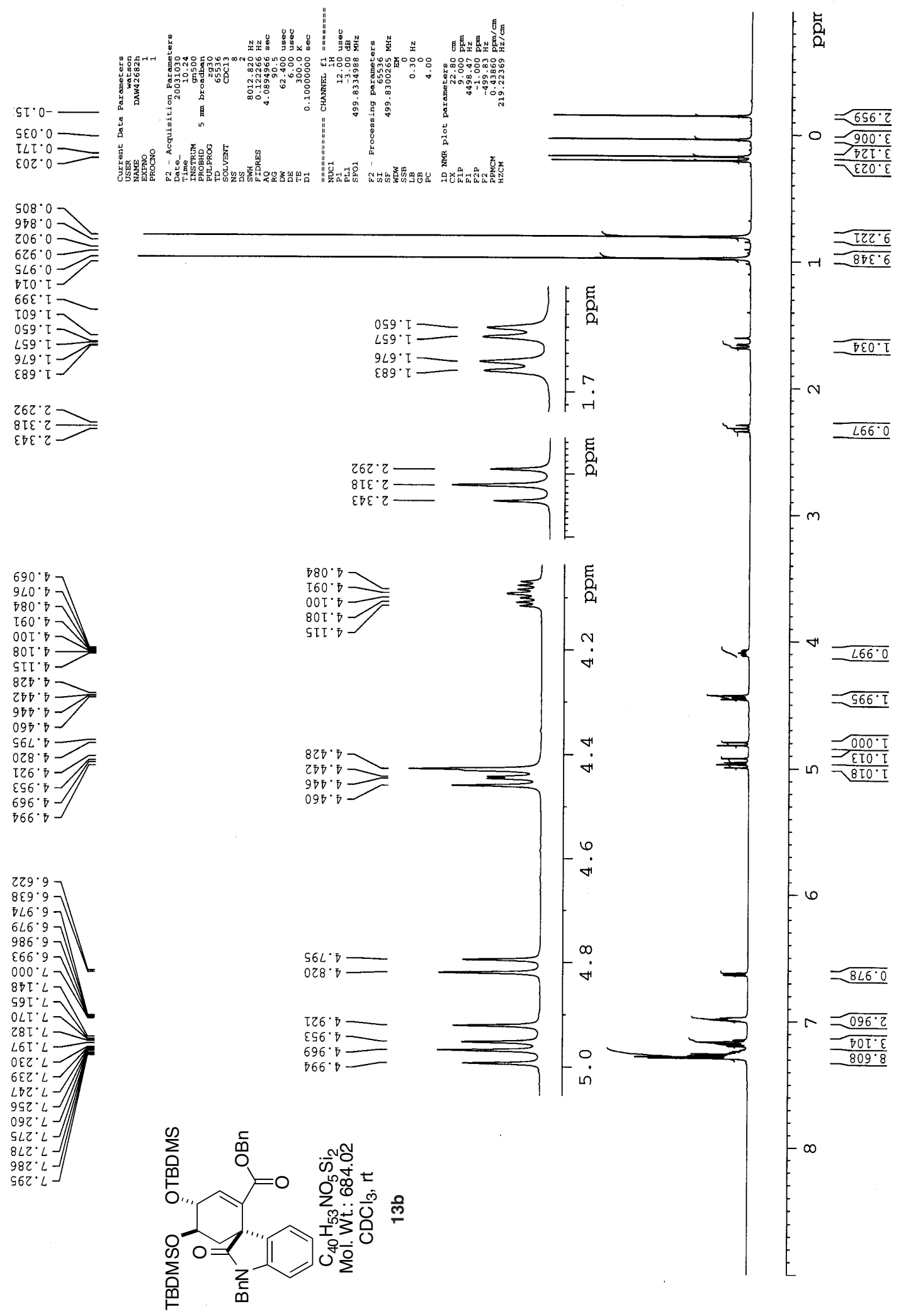




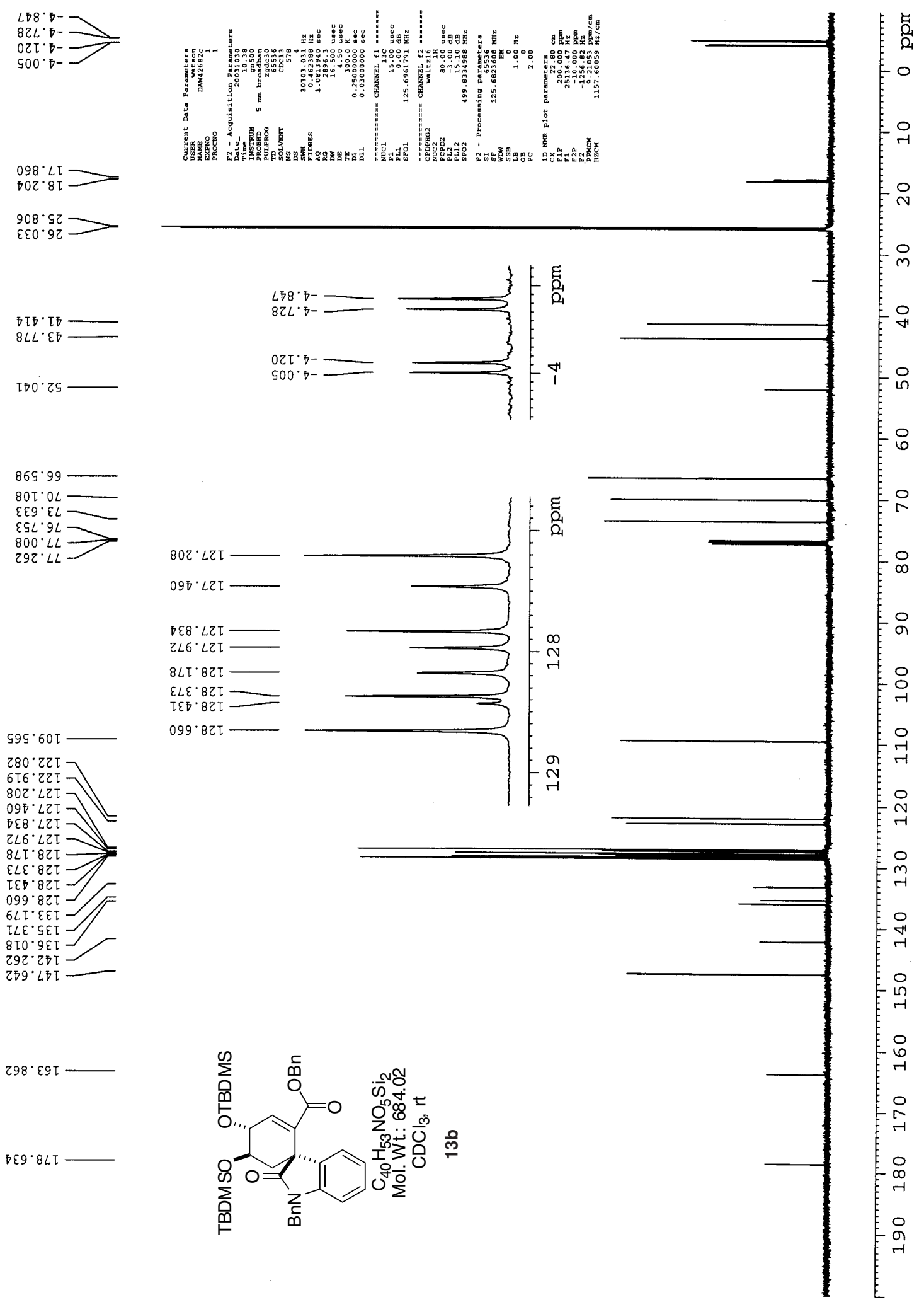



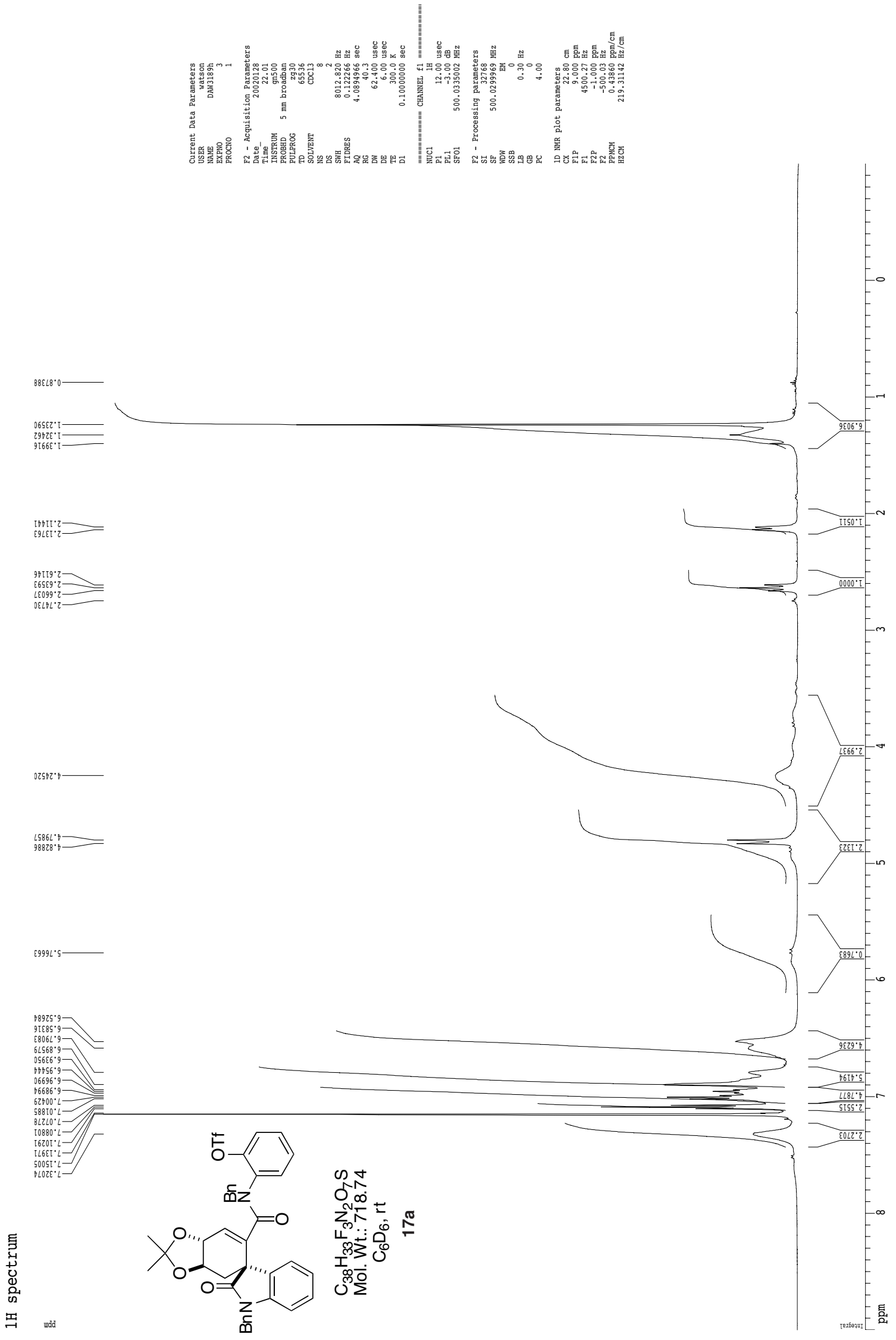
Supporting Information Overman and Watson
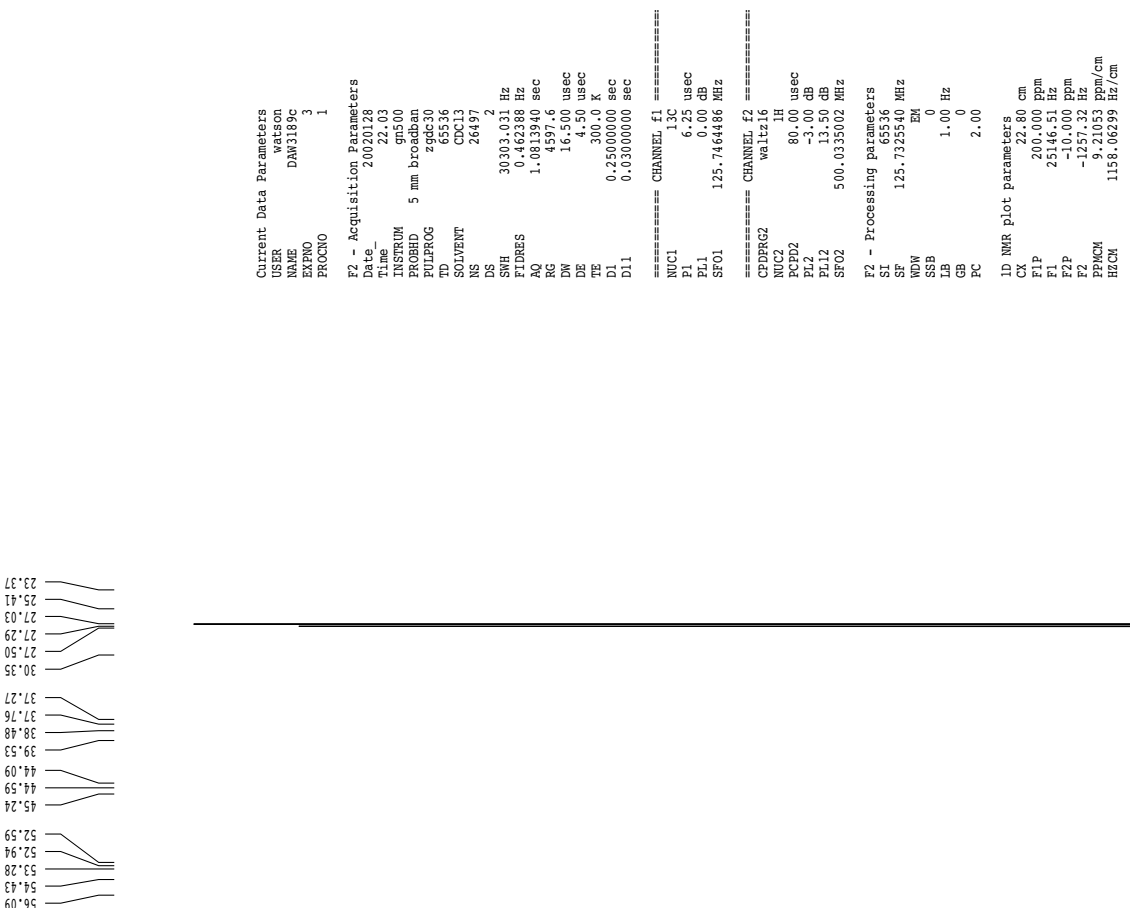

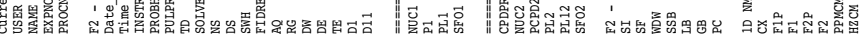

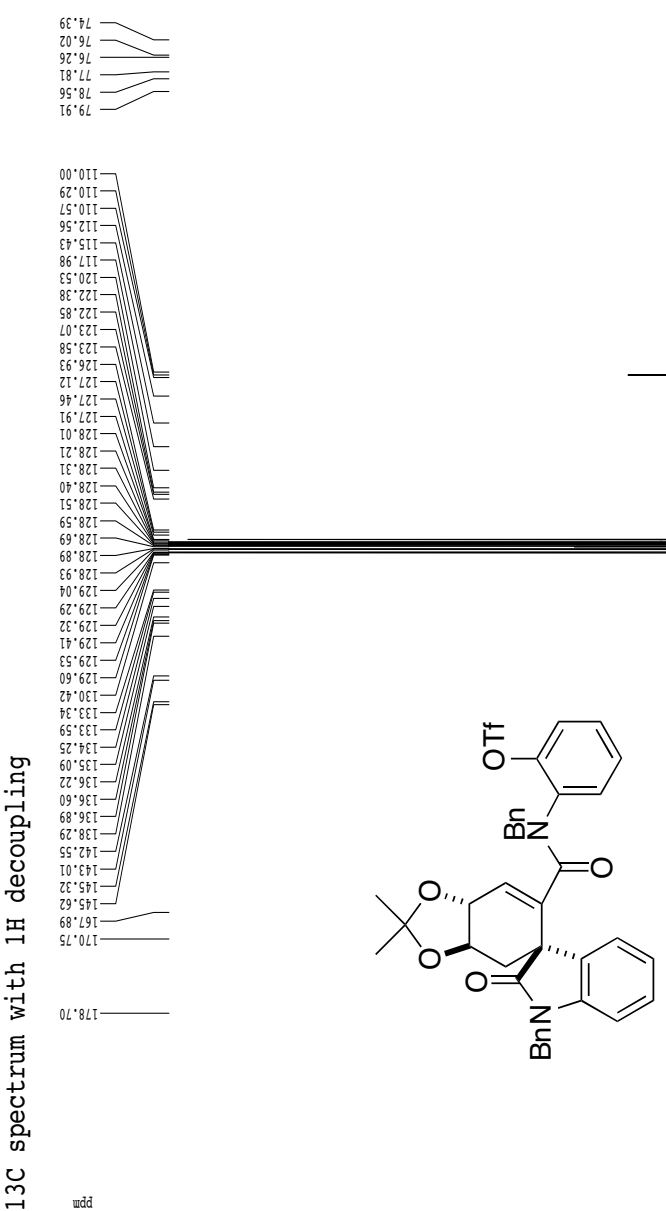

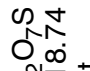

$\sum_{0}^{\infty} \frac{1}{1}=$

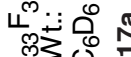

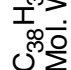



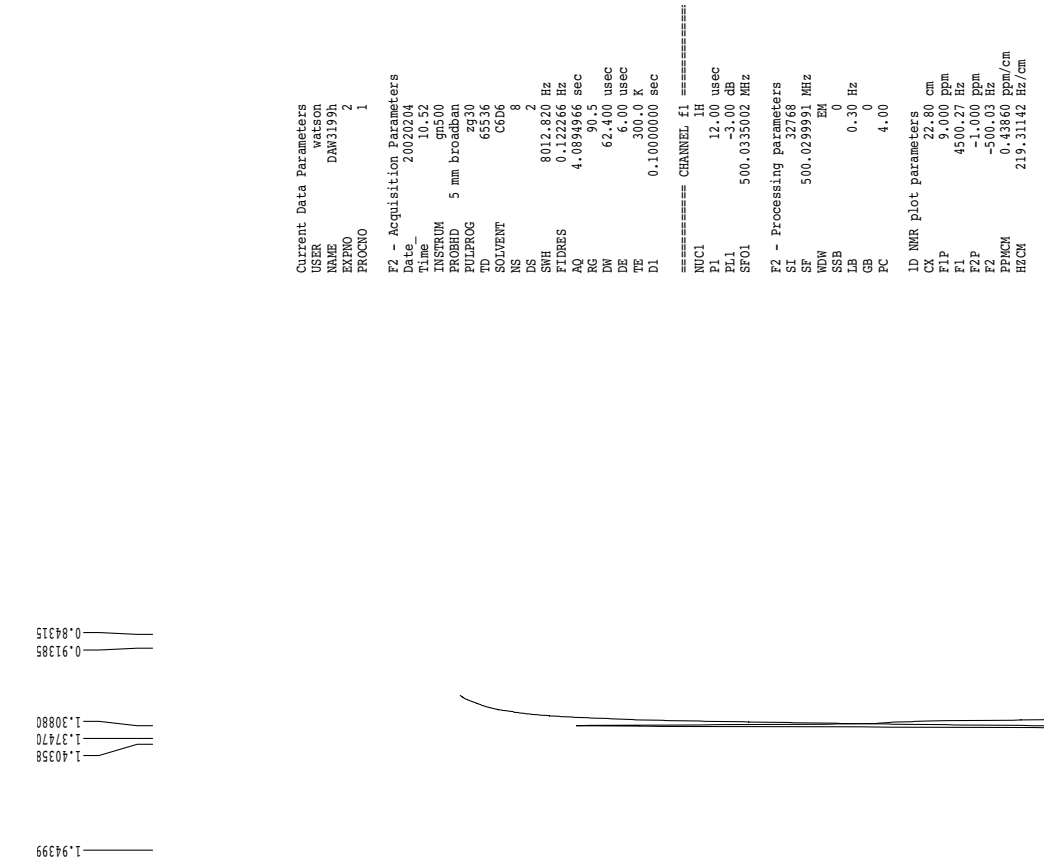

b9529' 2

$966 \varepsilon \varsigma^{\circ} \varepsilon-$
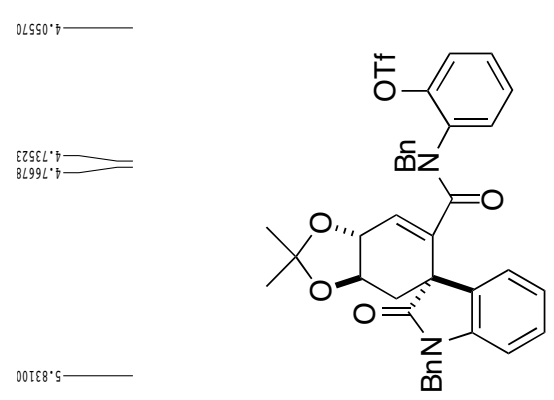

$\int_{0 \infty}^{\infty}$

$\sum_{0}^{\infty} \pi \pm \frac{\pi}{\pi} \pi \frac{\pi}{4}$

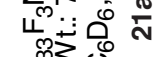

Tín

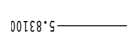

U ${ }^{\circ}$

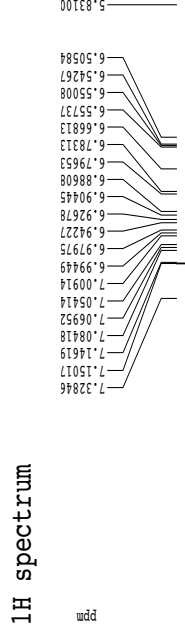

$$
\text { (n) }
$$



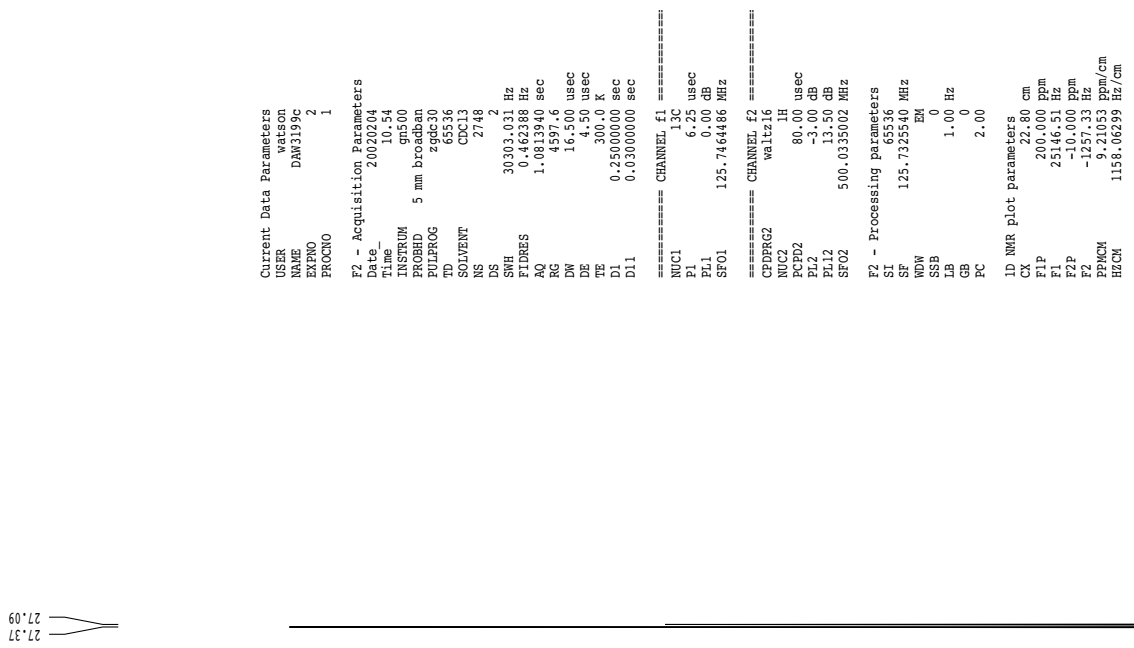

$\varepsilon \varepsilon^{\circ}\llcorner\varepsilon$

$6 L^{\circ}+6$

$96^{\circ} 75$
$17^{\prime} 75$

$6 T^{\circ} 8 L$

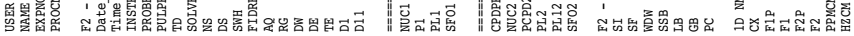

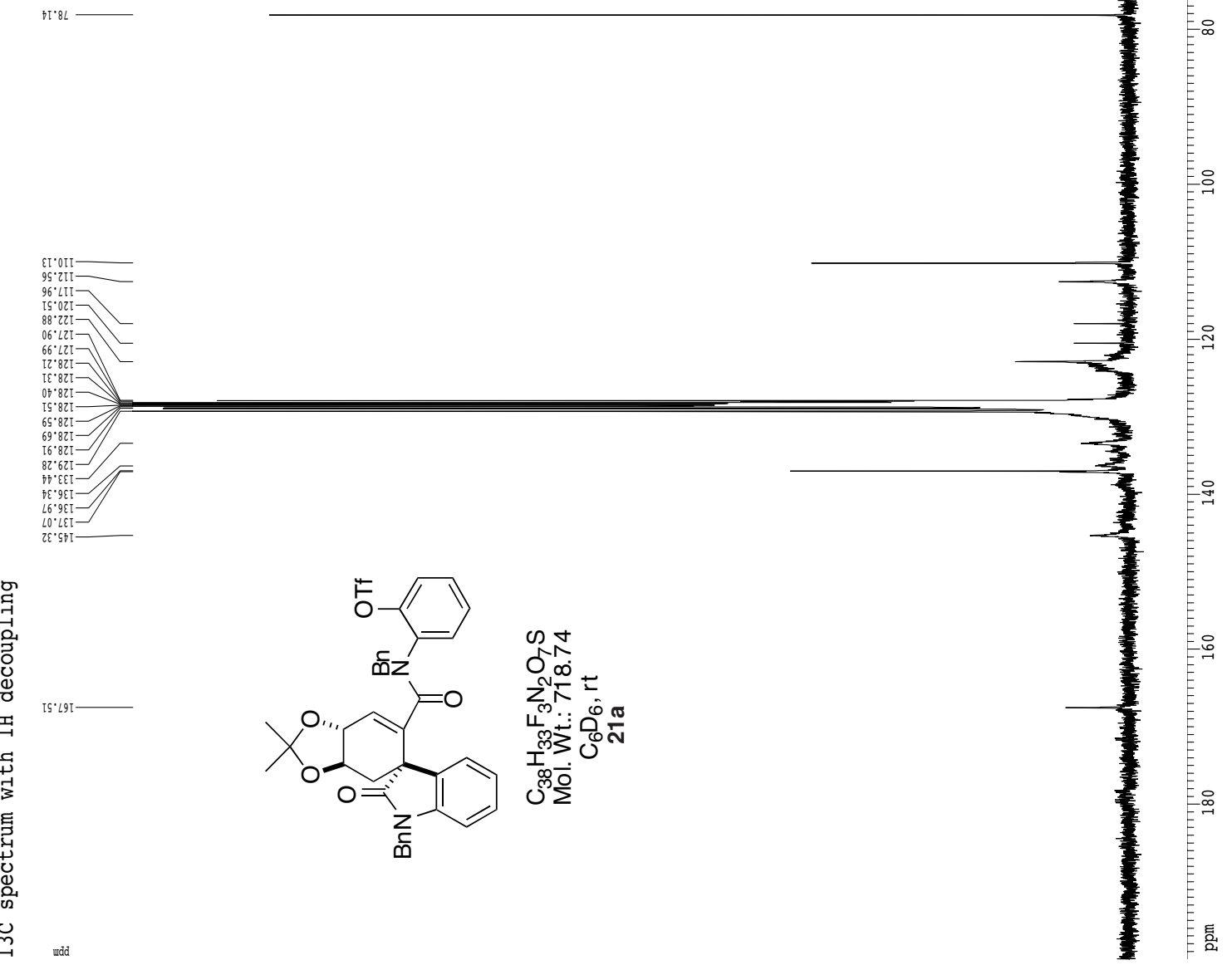




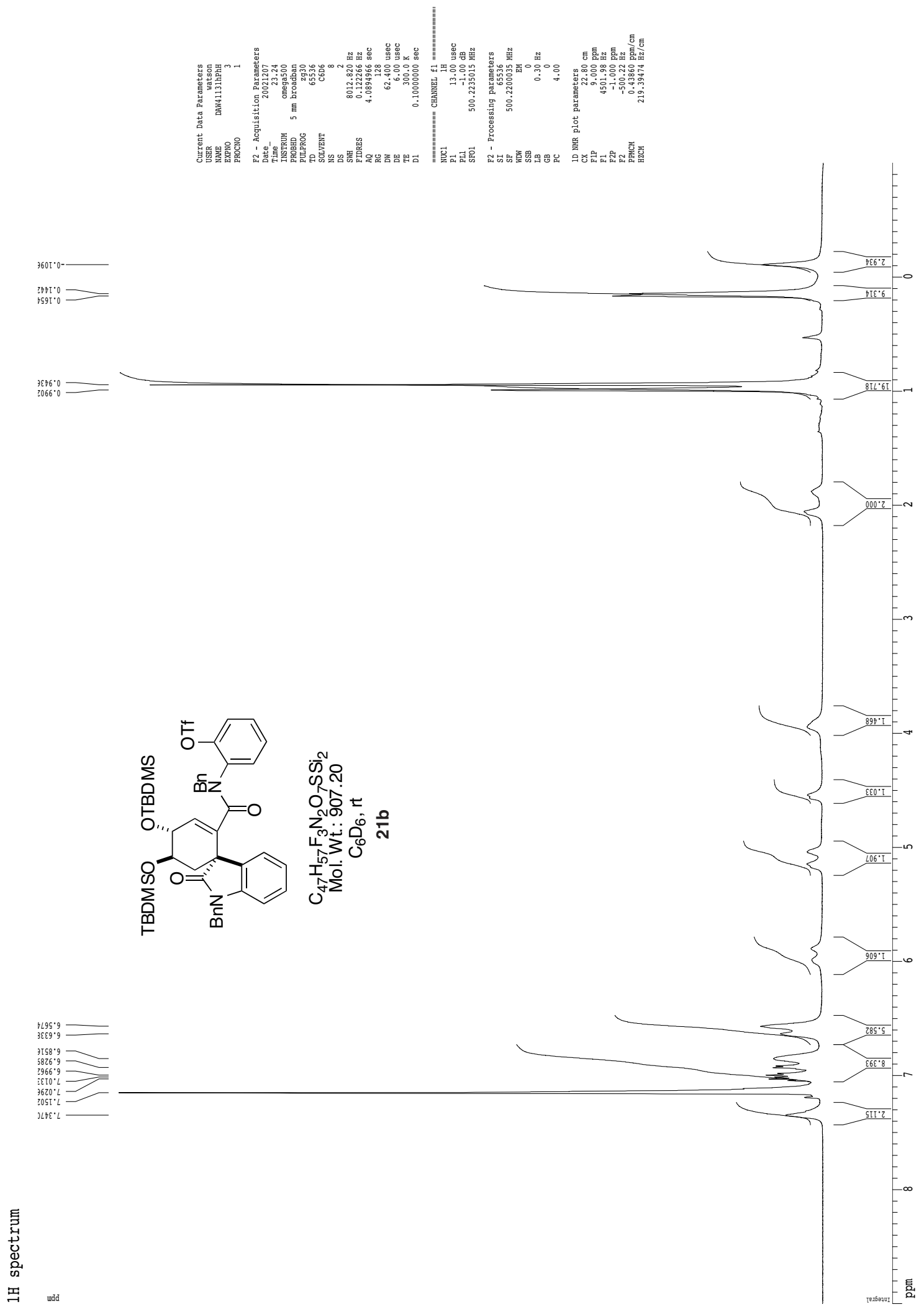




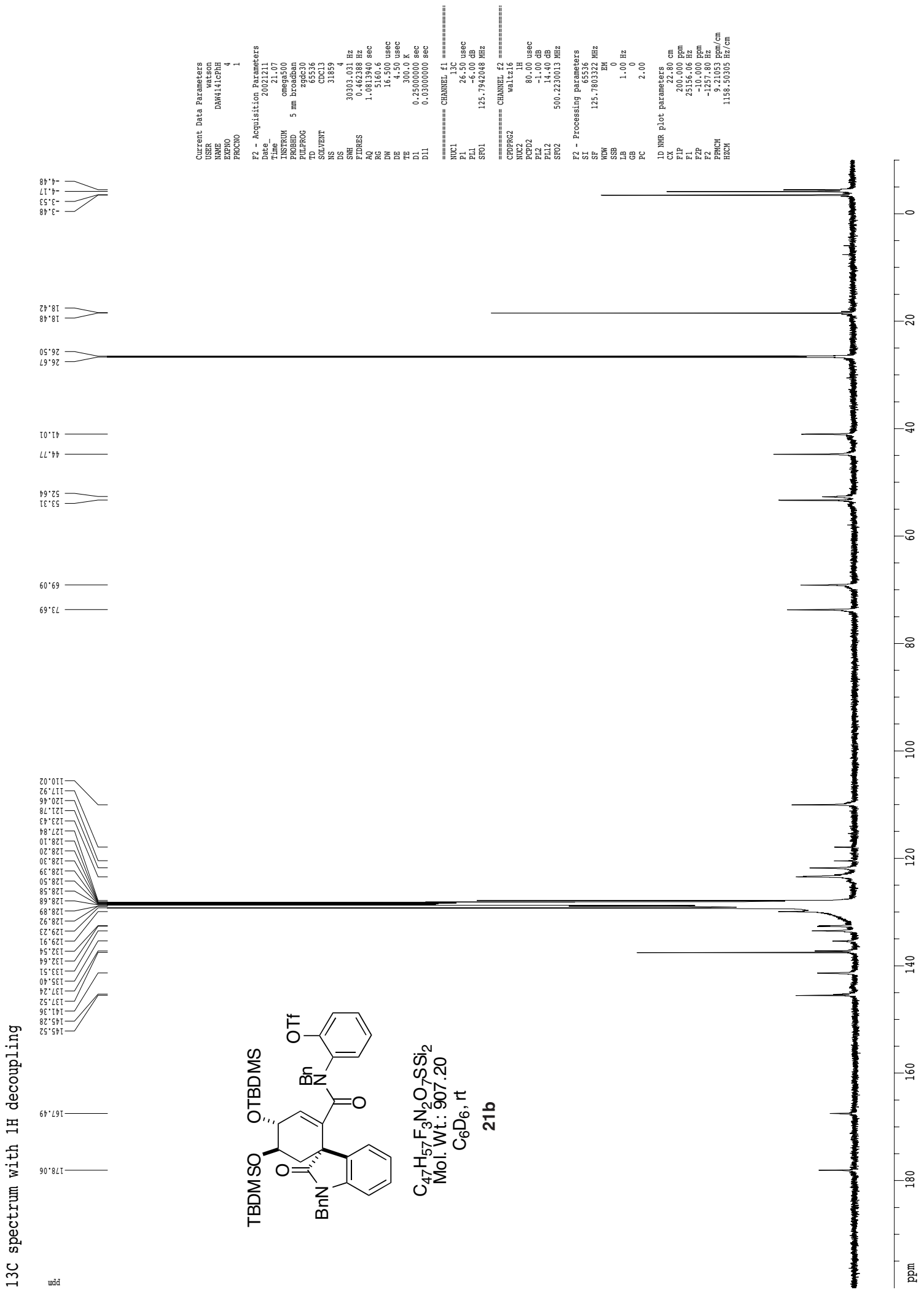




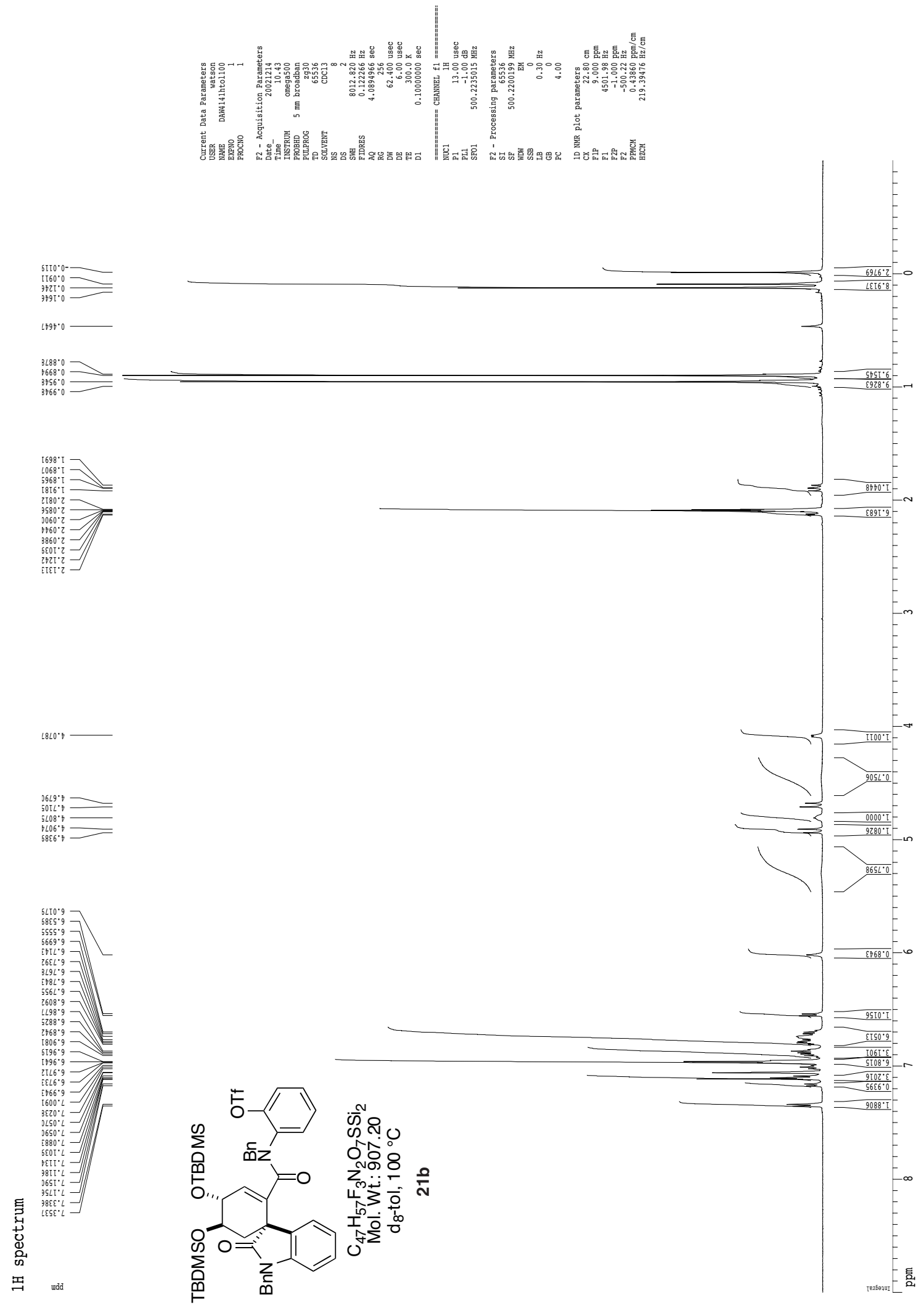




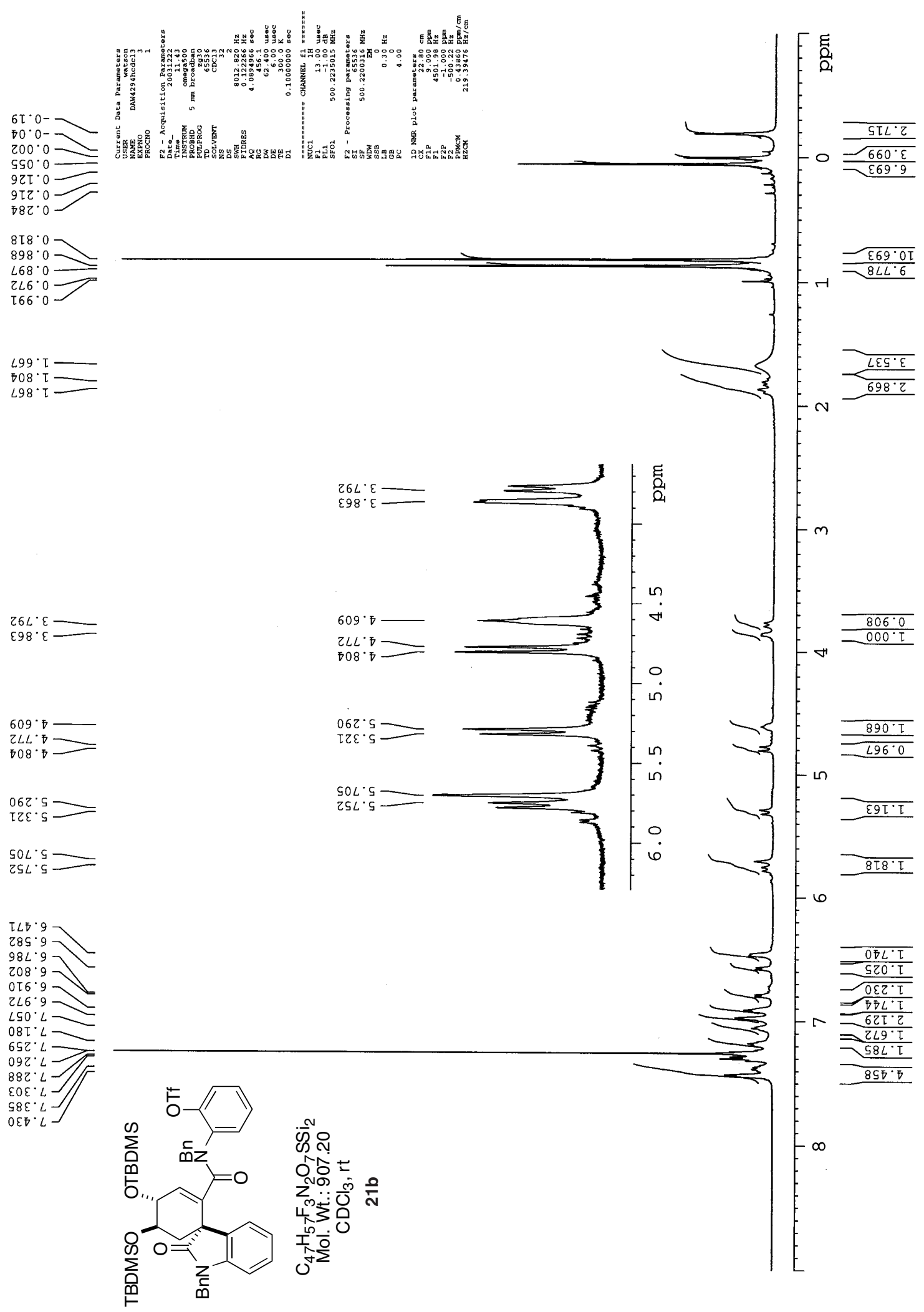


Supporting Information Overman and Watson

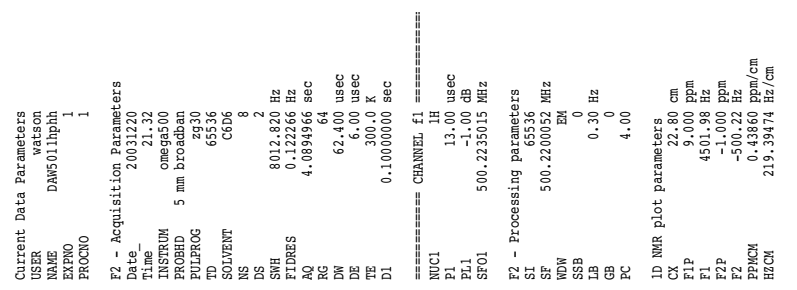

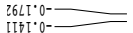

$\Rightarrow \angle 00^{\circ} 0-$

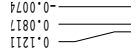

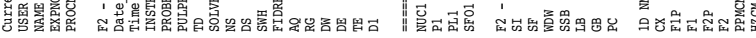

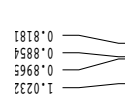

วนะ6

$3665^{\circ} 2$

LotI'

s70 $0 \varepsilon^{\circ} \mathrm{C}$

$2027 \cdot 7$
$\operatorname{sicS} \cdot 7$
$2 G S \cdot 7$

${ }^{6996^{\circ} \mathrm{T}}$
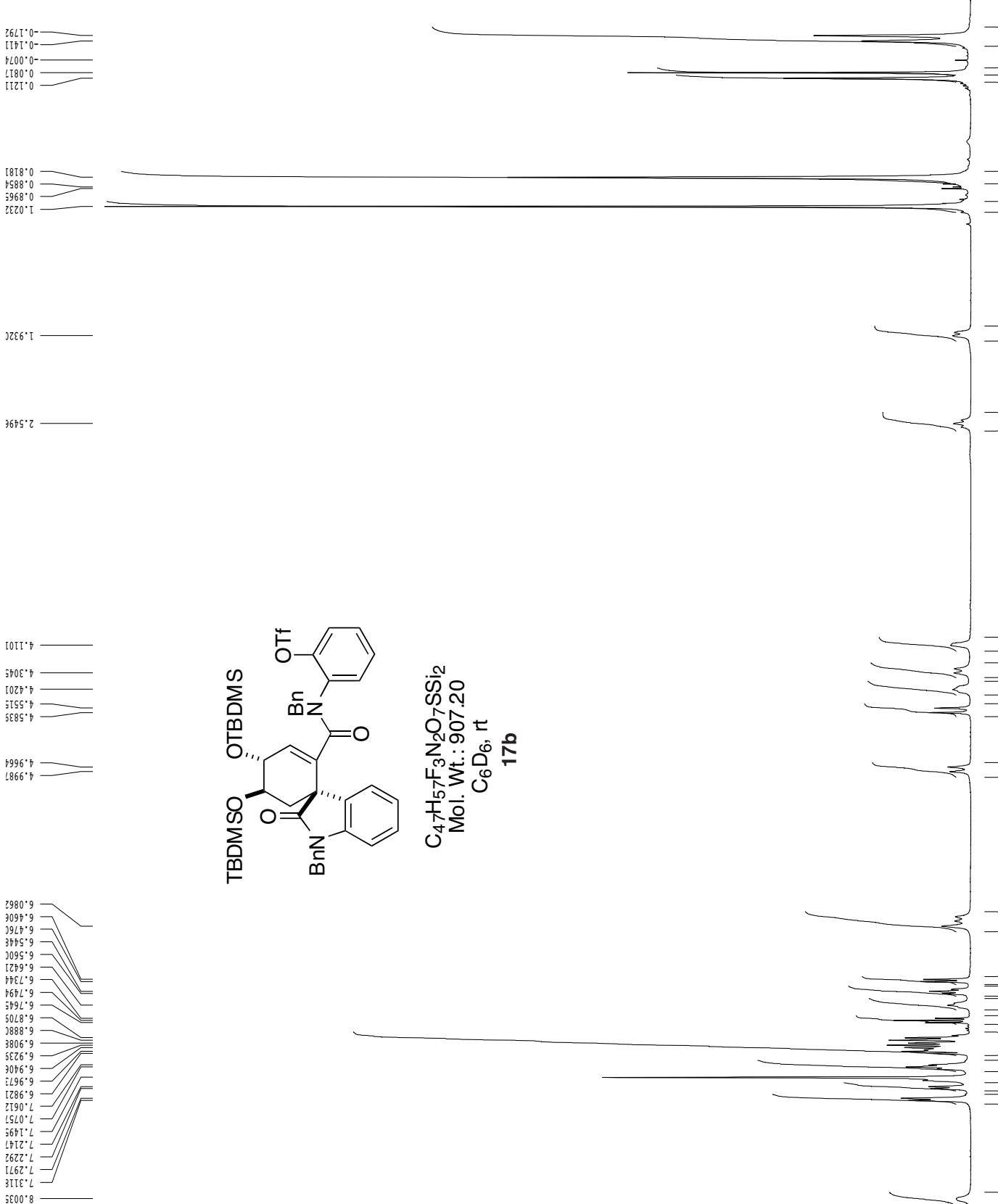

0.59 9

$\frac{7609^{\circ} \varepsilon}{6092^{\circ} \varepsilon}$

$\angle L 08^{\circ 6}$

$8666^{\circ} 6$

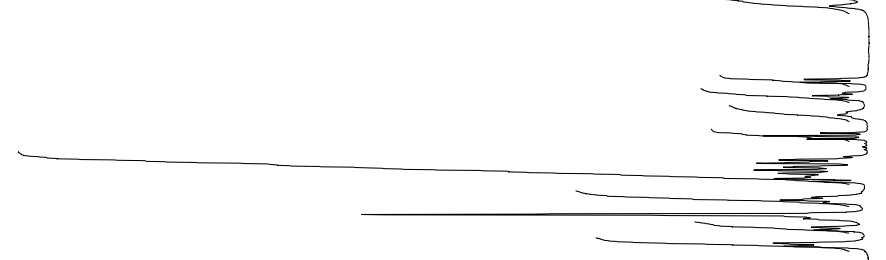

$\begin{array}{r}\quad 5000^{\circ} \mathrm{T} \\ \hline \hline \quad 6292^{\circ} \mathrm{T} \\ \hline \hline\end{array}$

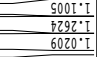

$\Rightarrow t 80^{\circ} \mathrm{L}$

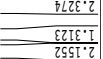

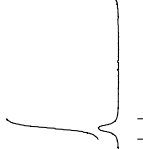

$\stackrel{n}{*}$ 

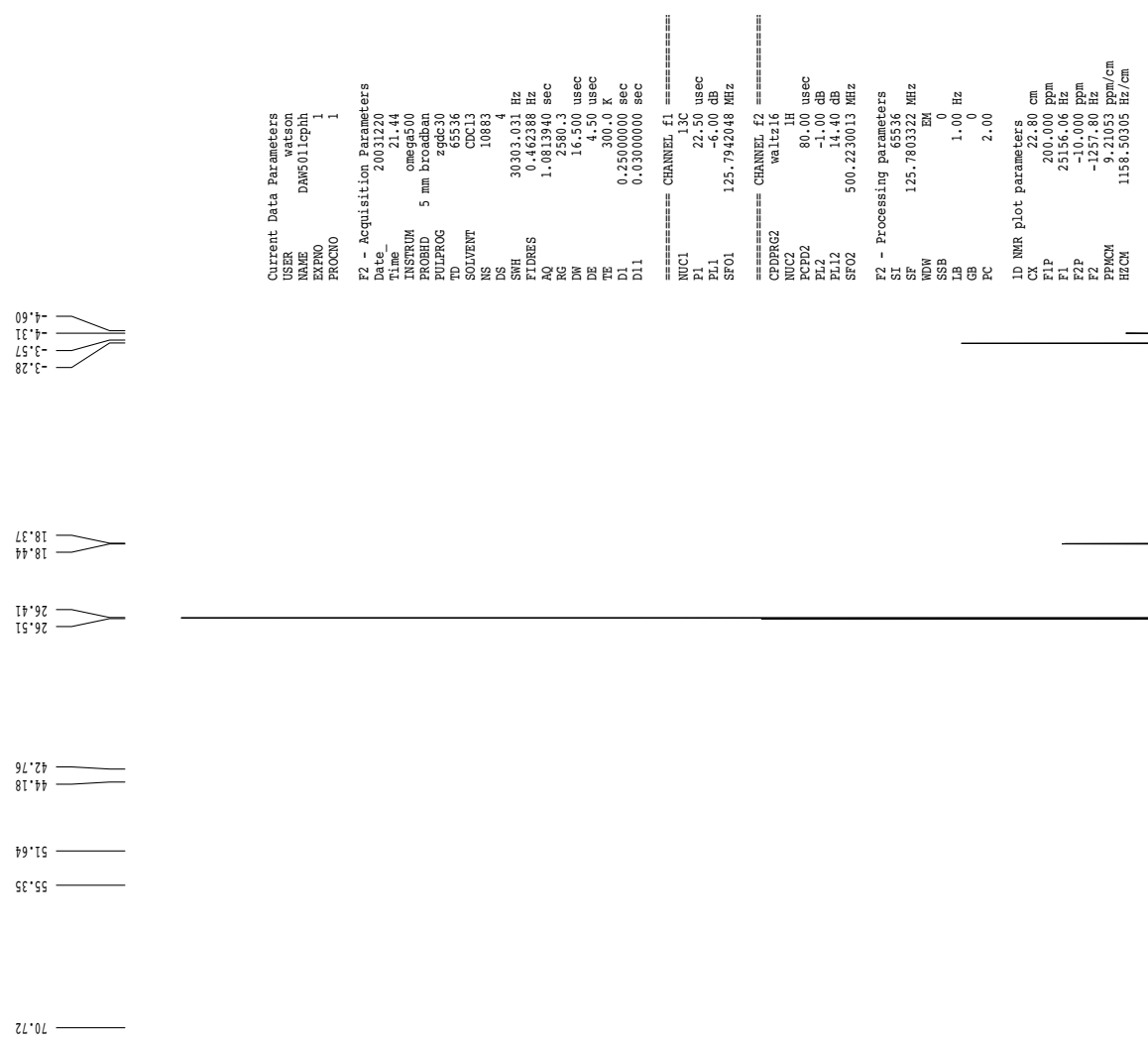

$6 S^{\circ}+t$
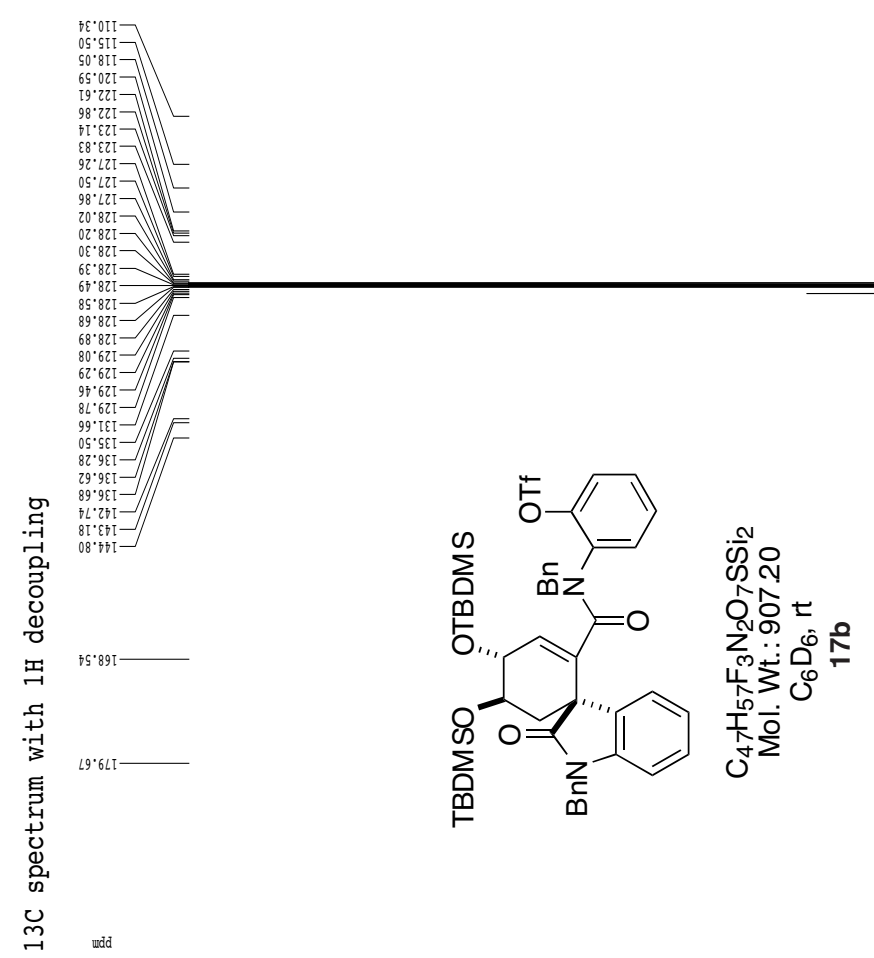

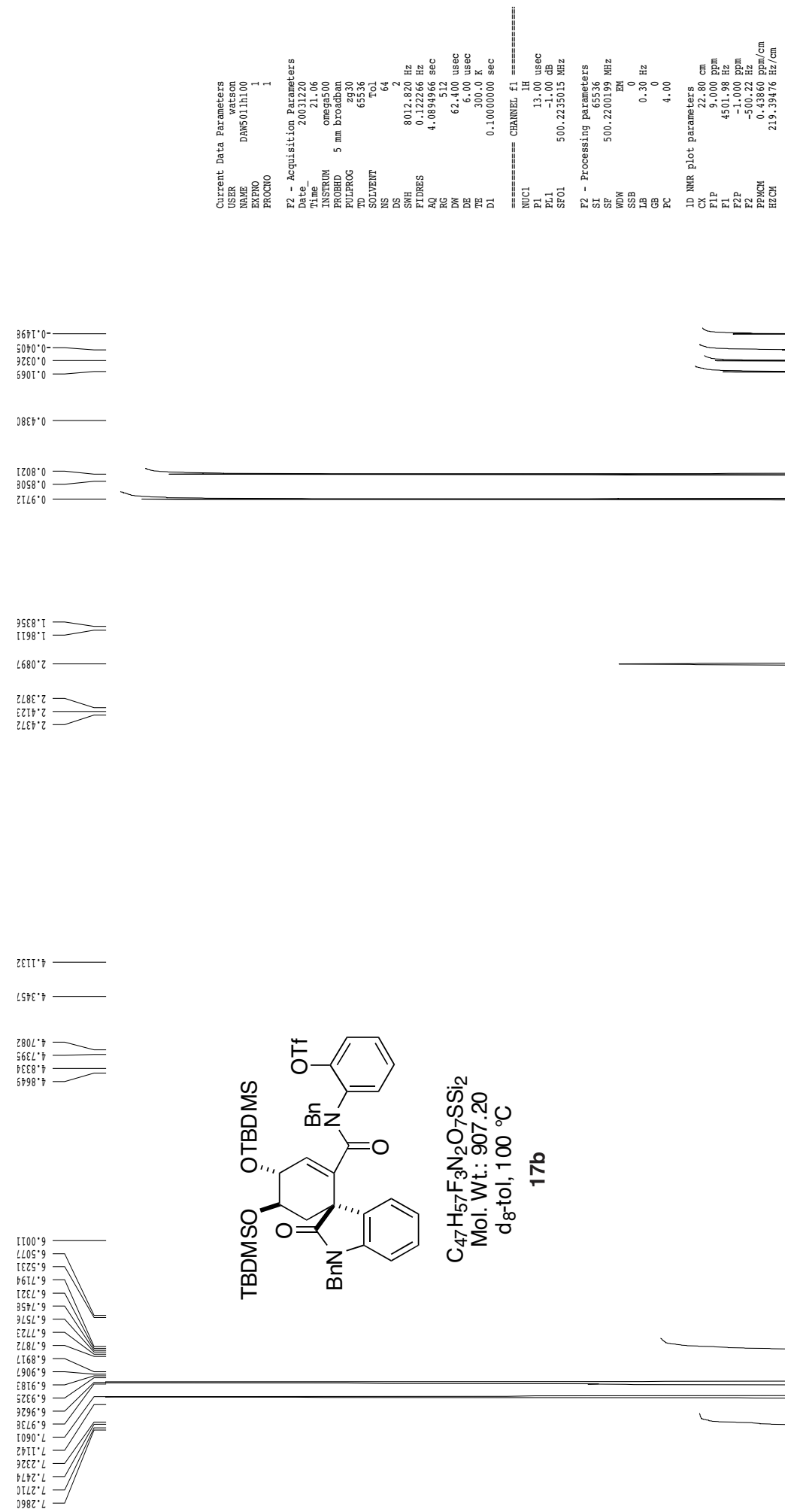

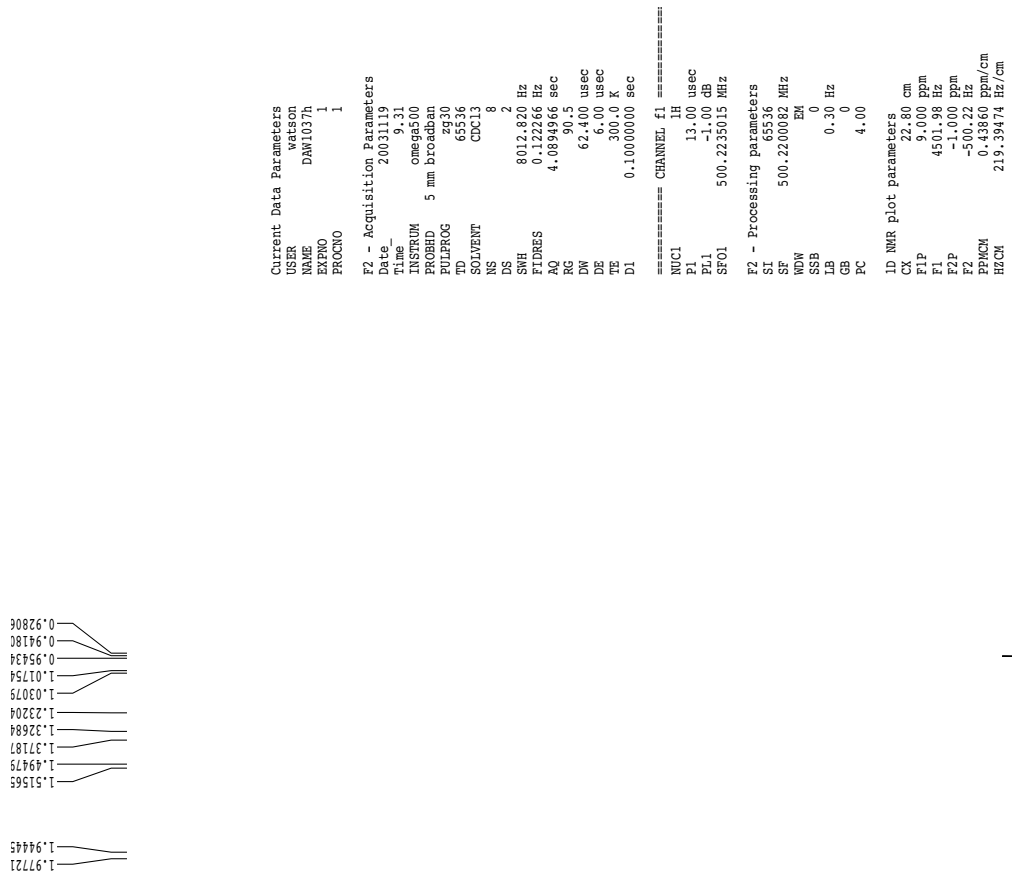

$32566^{\circ} 2$

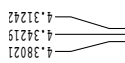

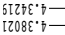

$30800^{\circ} \mathrm{g}=$

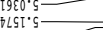

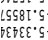

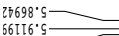

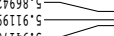
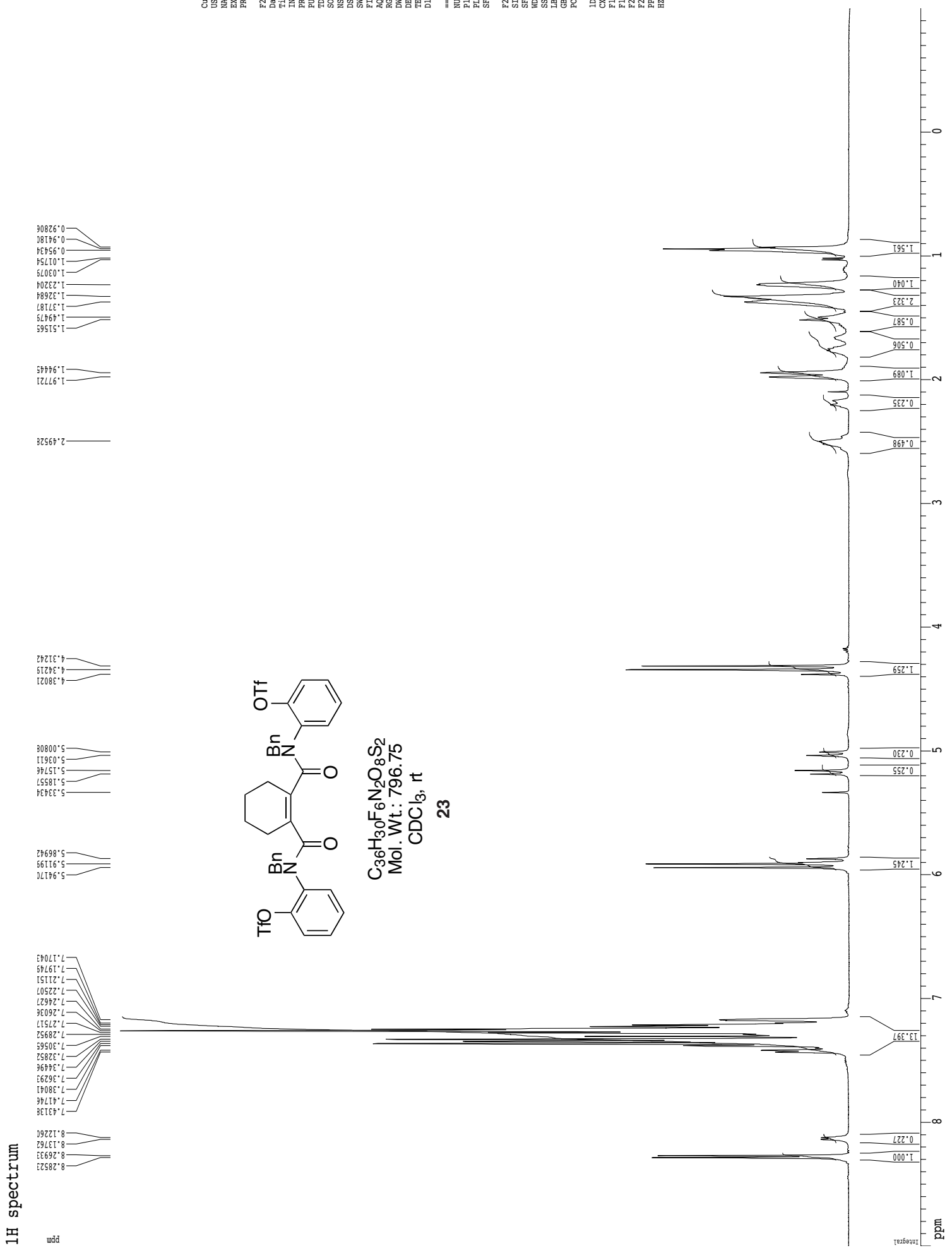

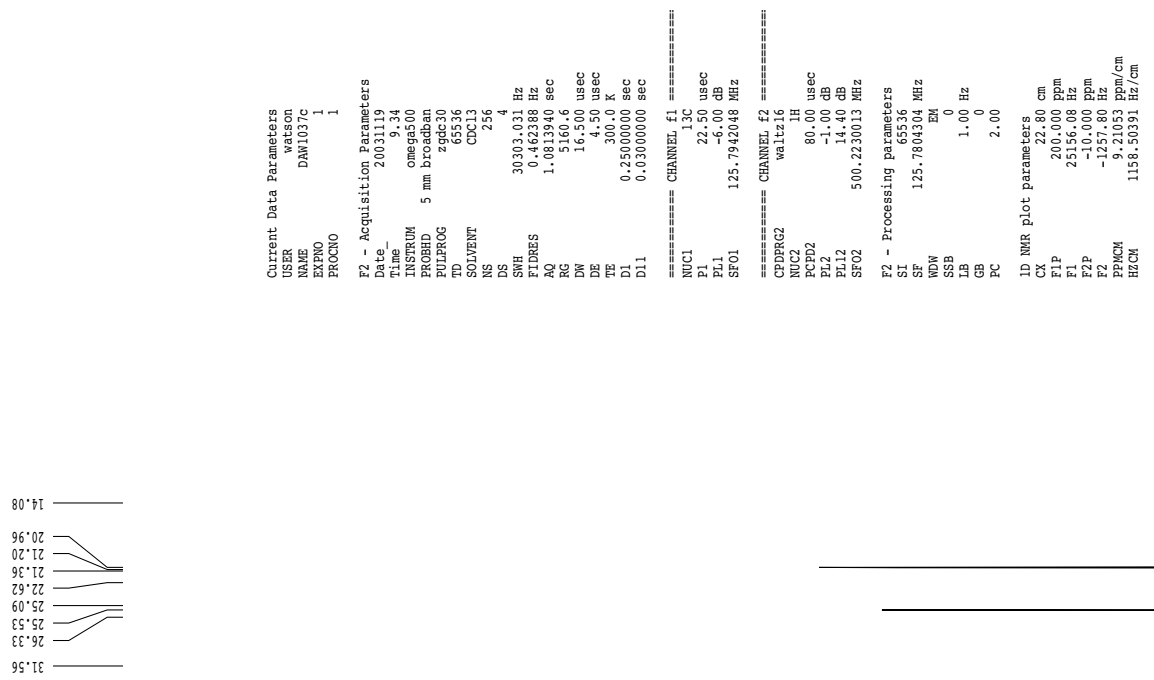

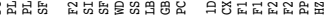
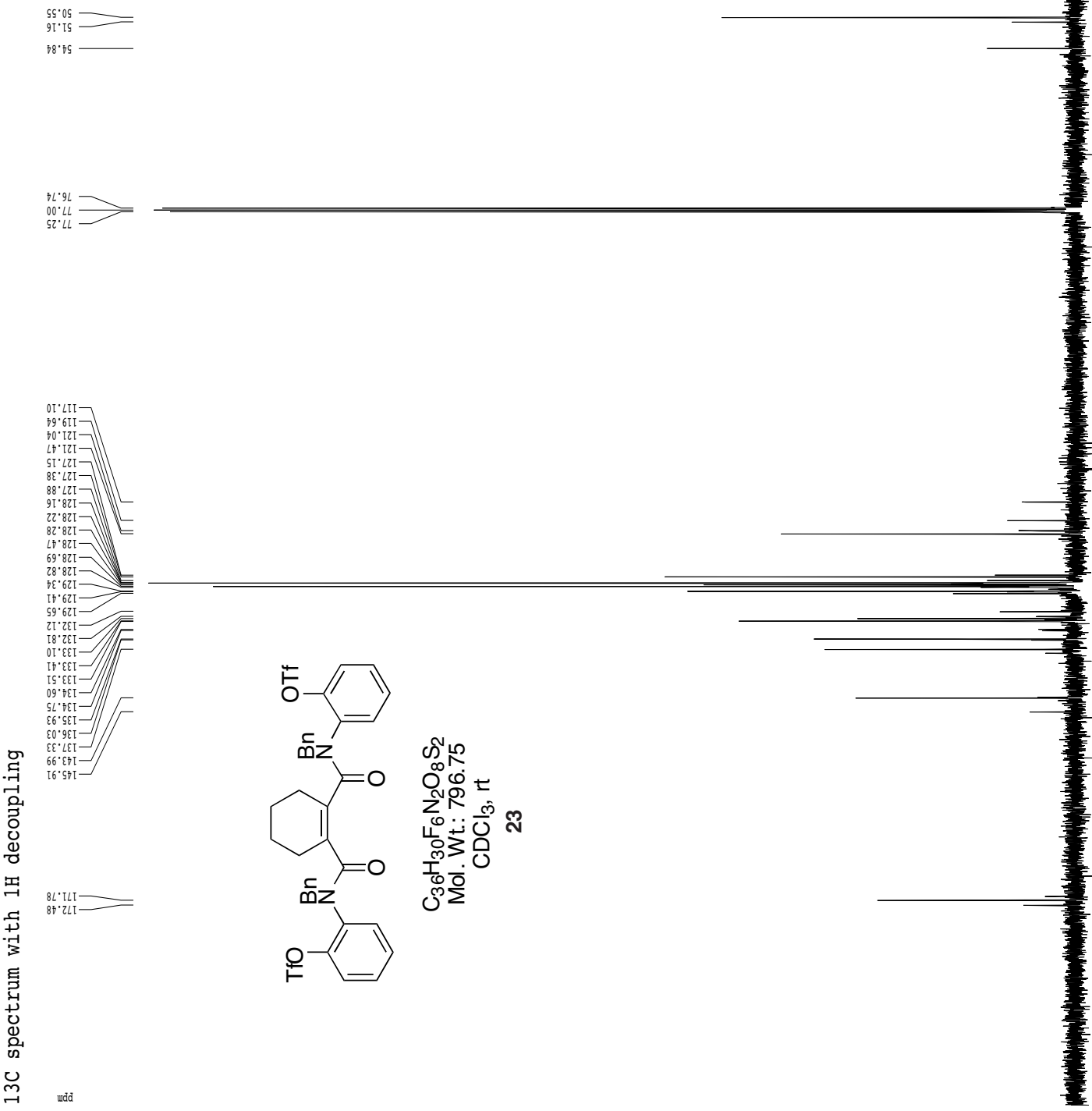

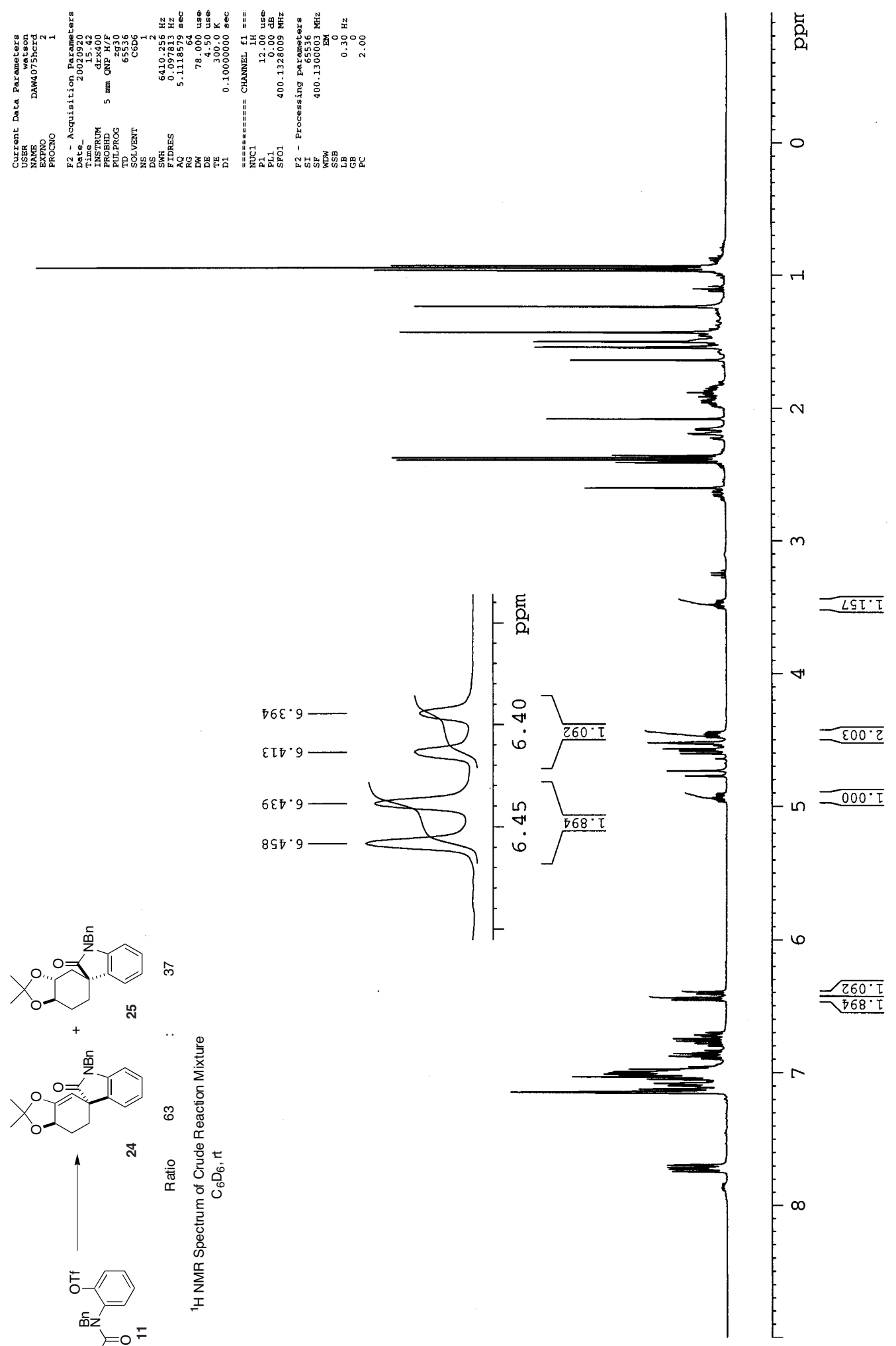

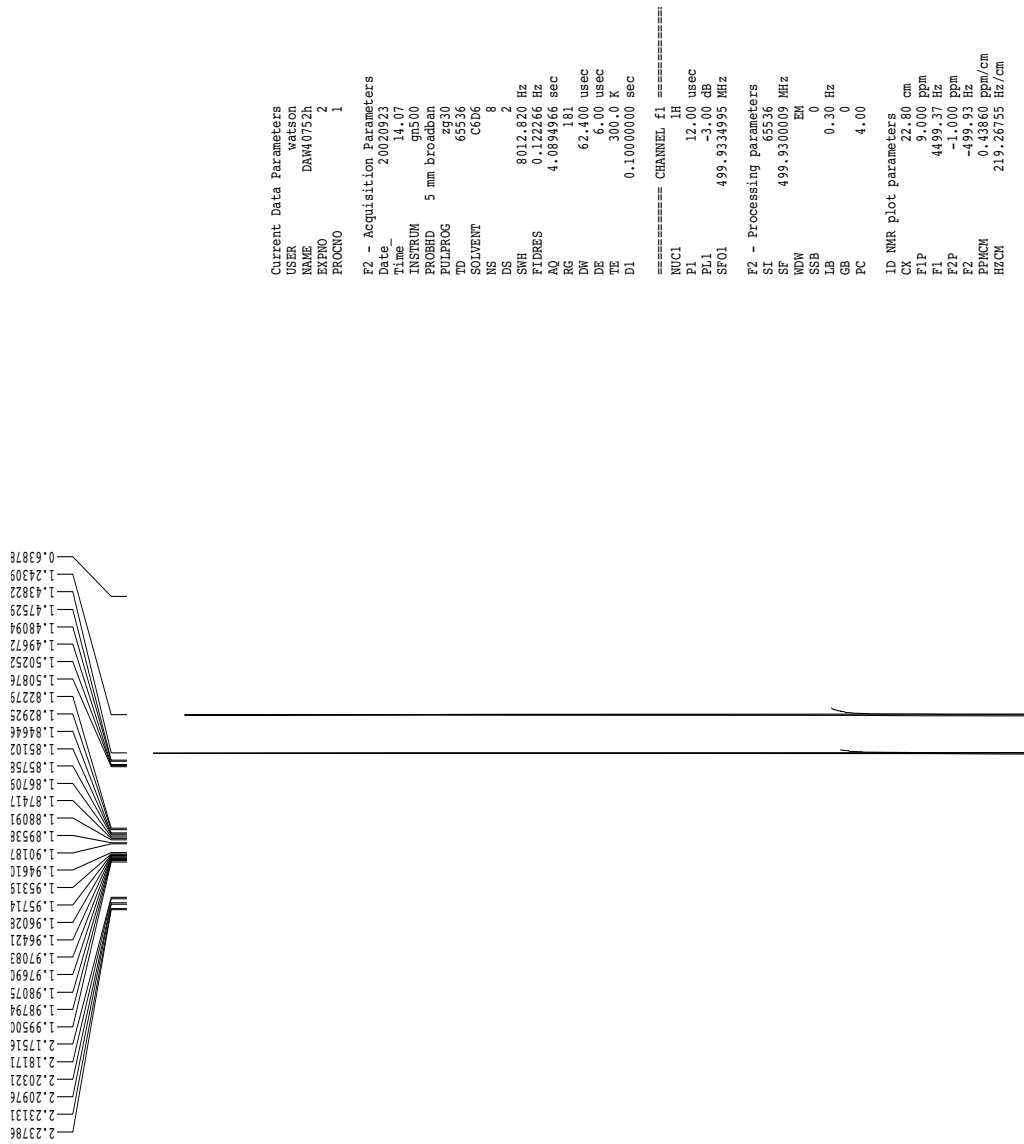

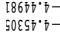

$88099^{\prime}, 7-7$

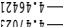

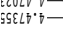

$29788^{\circ} \cdot 7$

$38885^{\circ} \cdot 7$

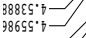

$3562 L^{\circ} \forall-$

$3809 L^{\prime} \circ-$

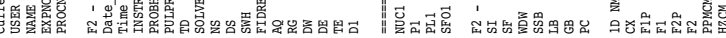
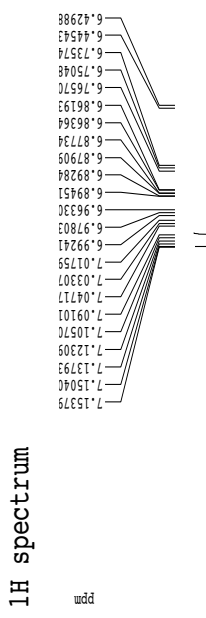

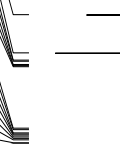
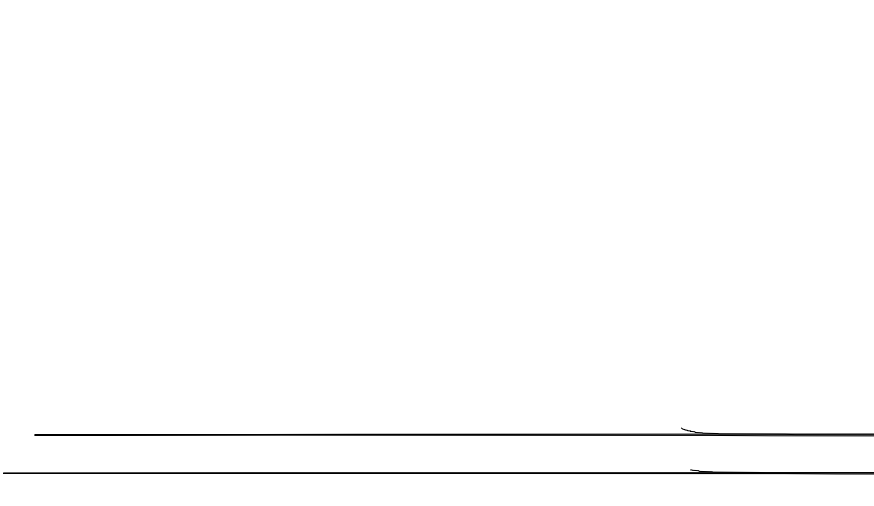

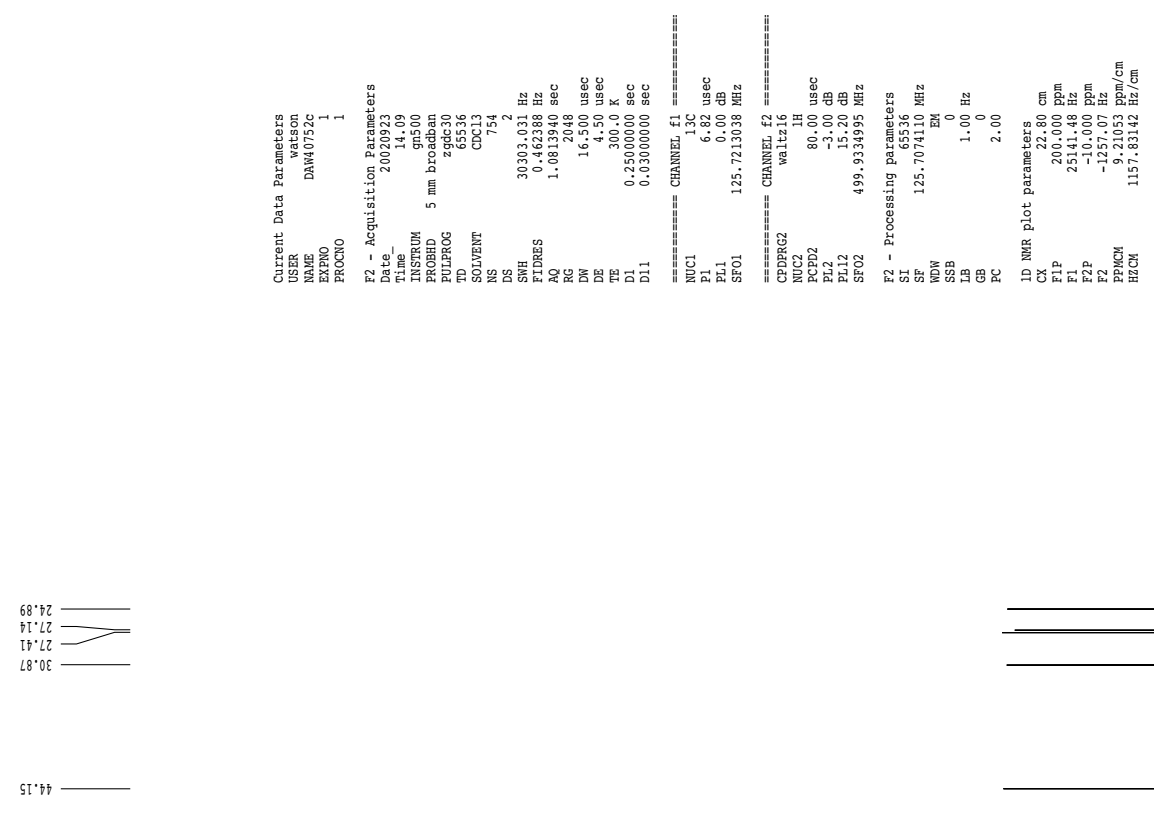

$88^{\circ} \cdot 05$

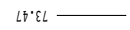

$\varepsilon \tau^{2} 26-$

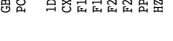

$\angle F^{\prime} \varepsilon L$
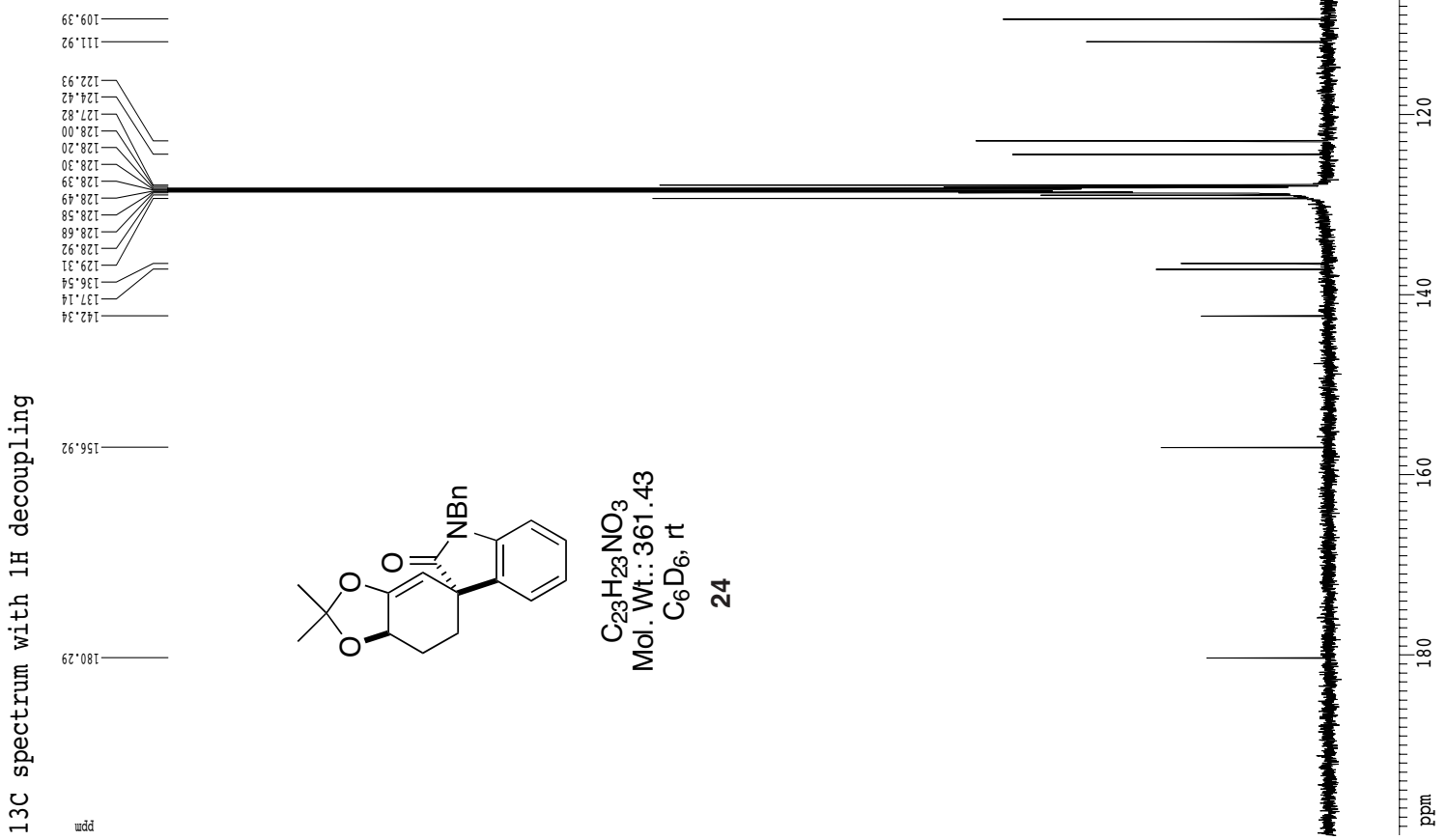
Supporting Information Overman and Watson

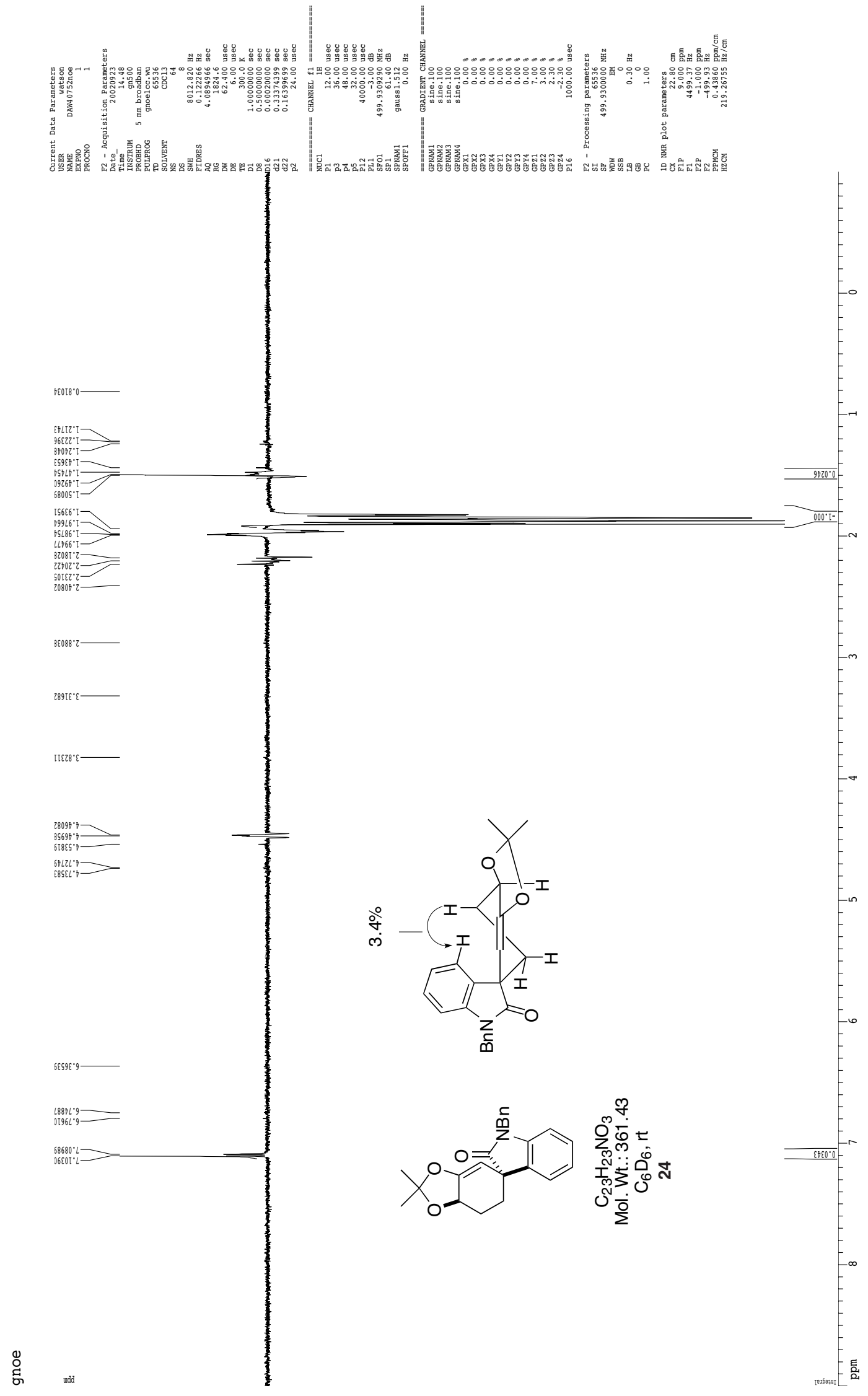


Supporting Information Overman and Watson

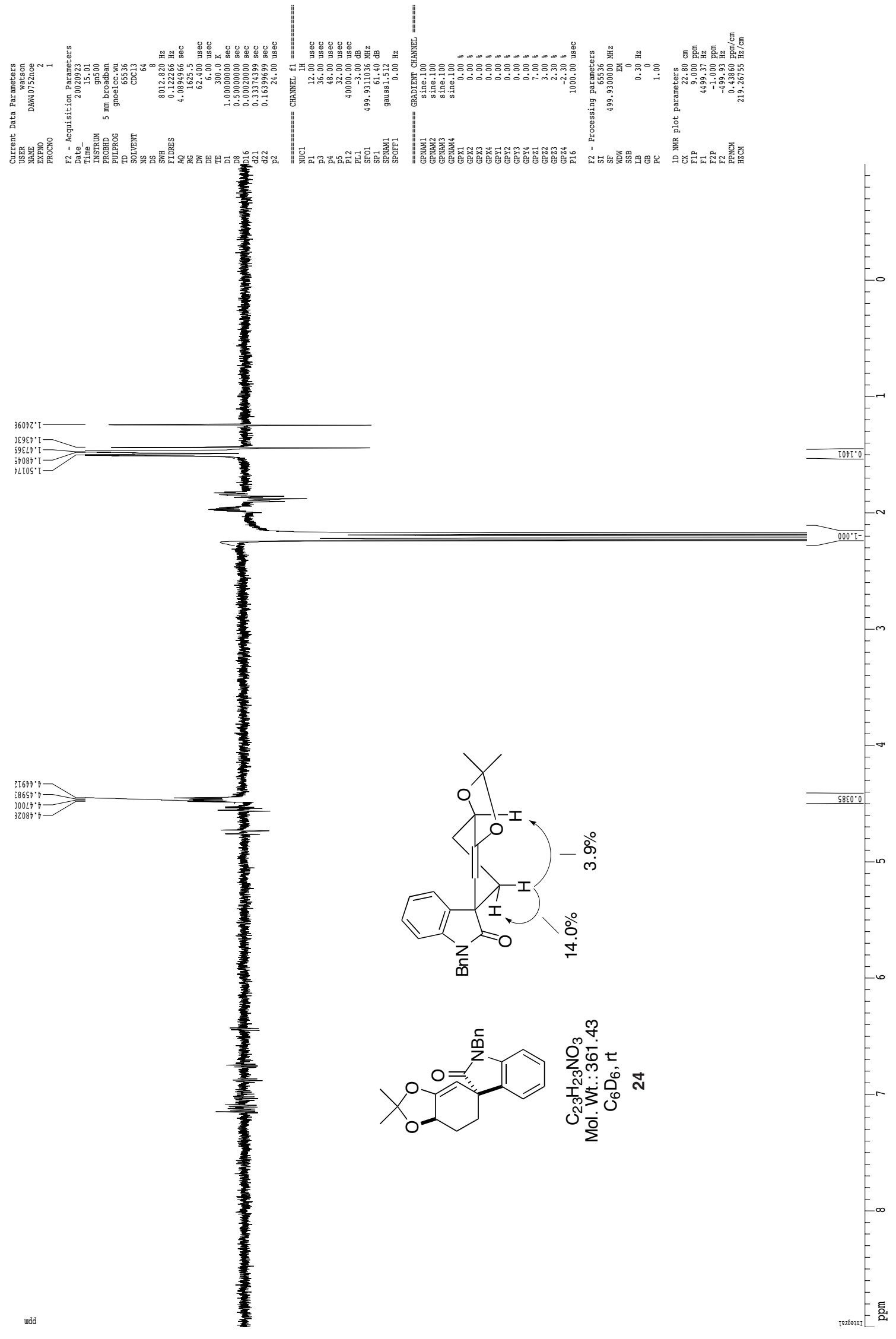



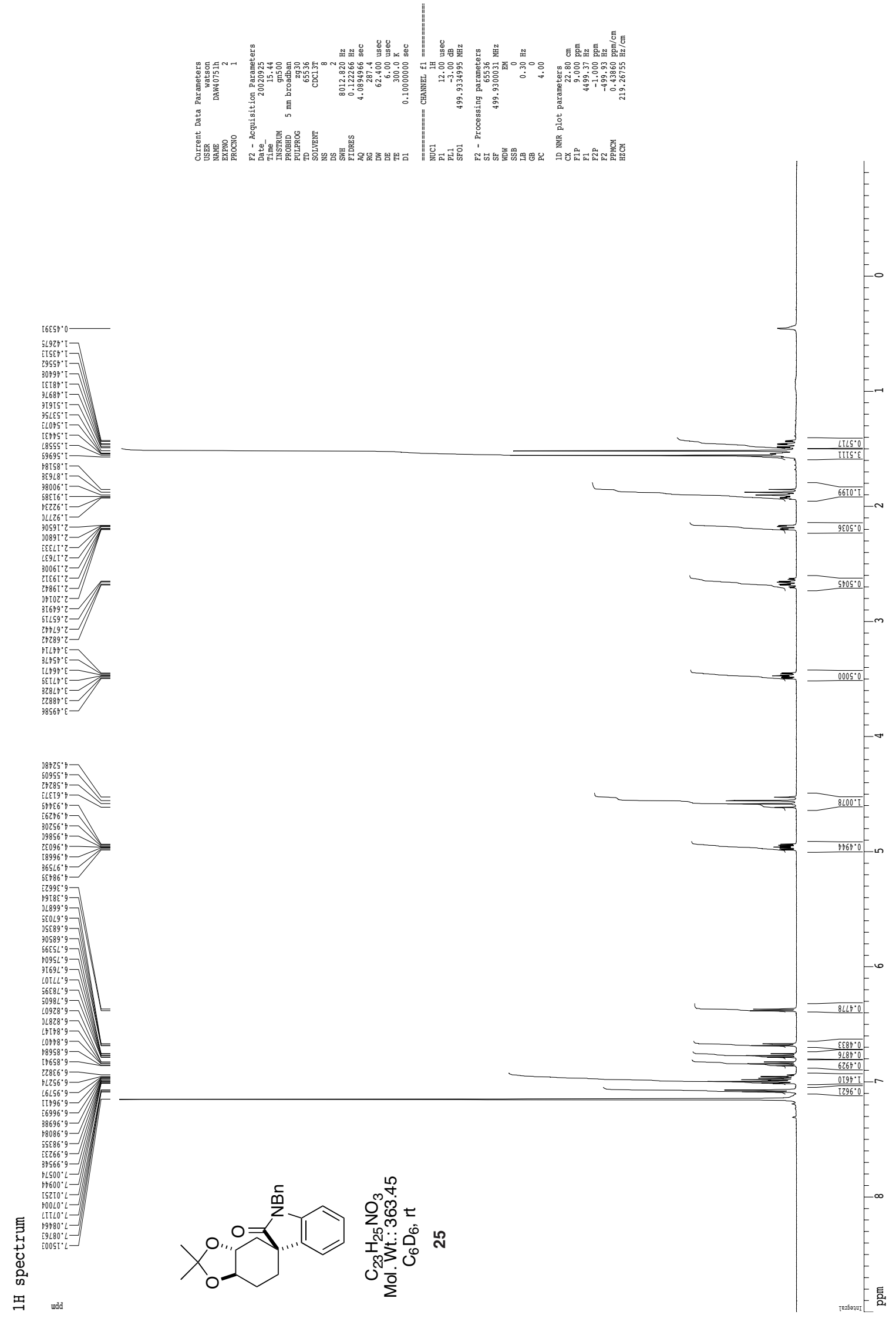
Supporting Information Overman and Watson
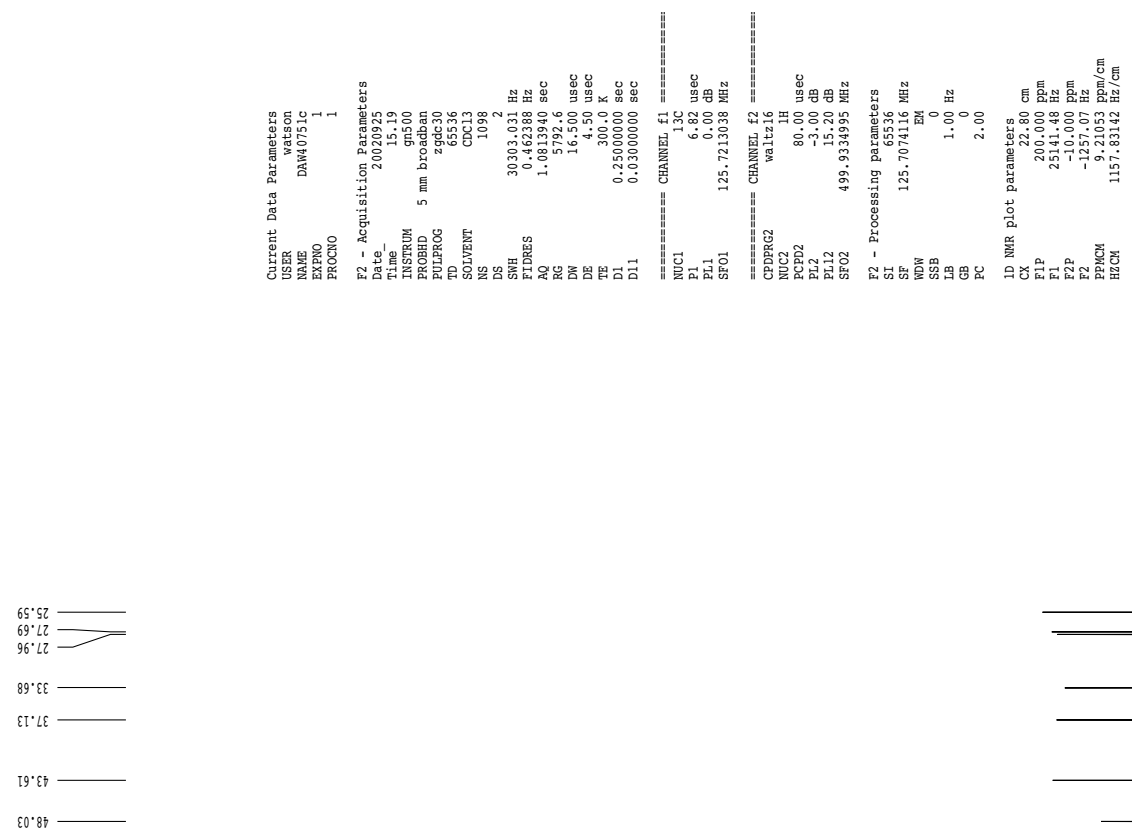

OS.SL

I2'T8
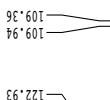

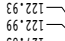

ع8. 2617

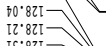

ortsegr

65.882-

5:6201



เ5' 271
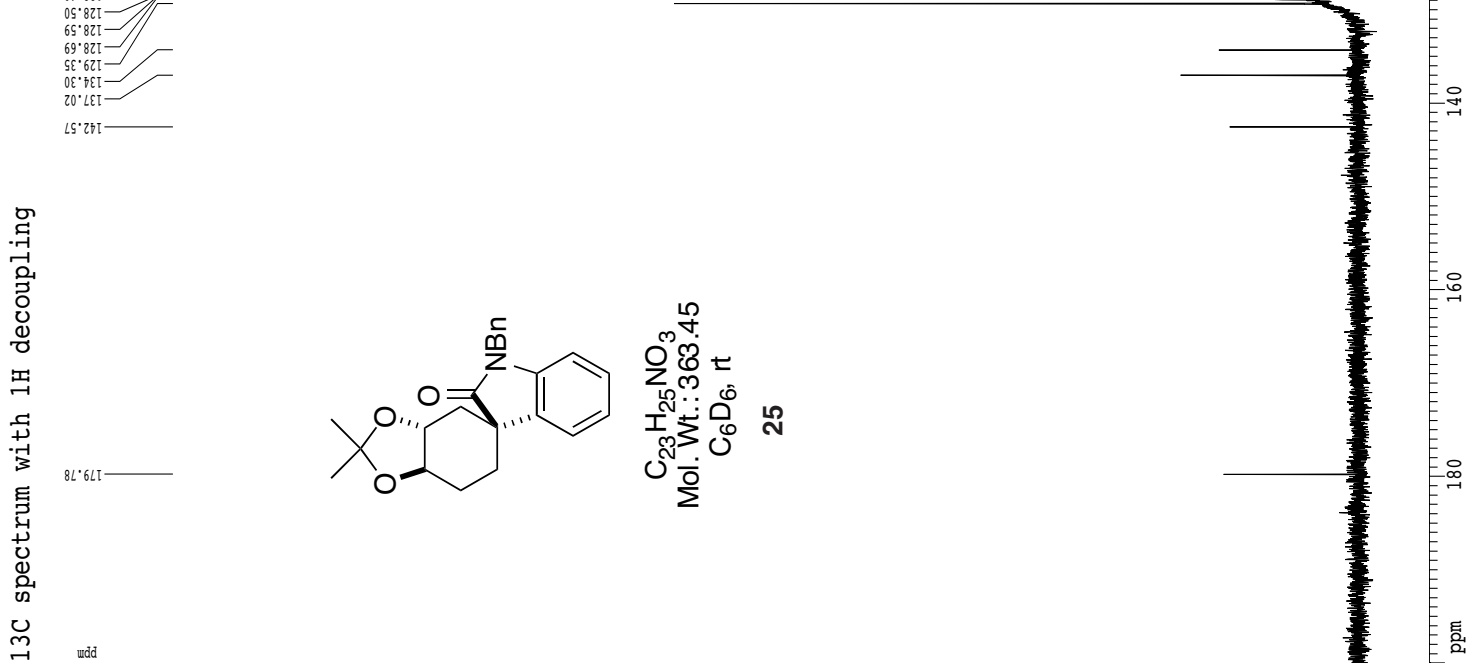
Supporting Information Overman and Watson

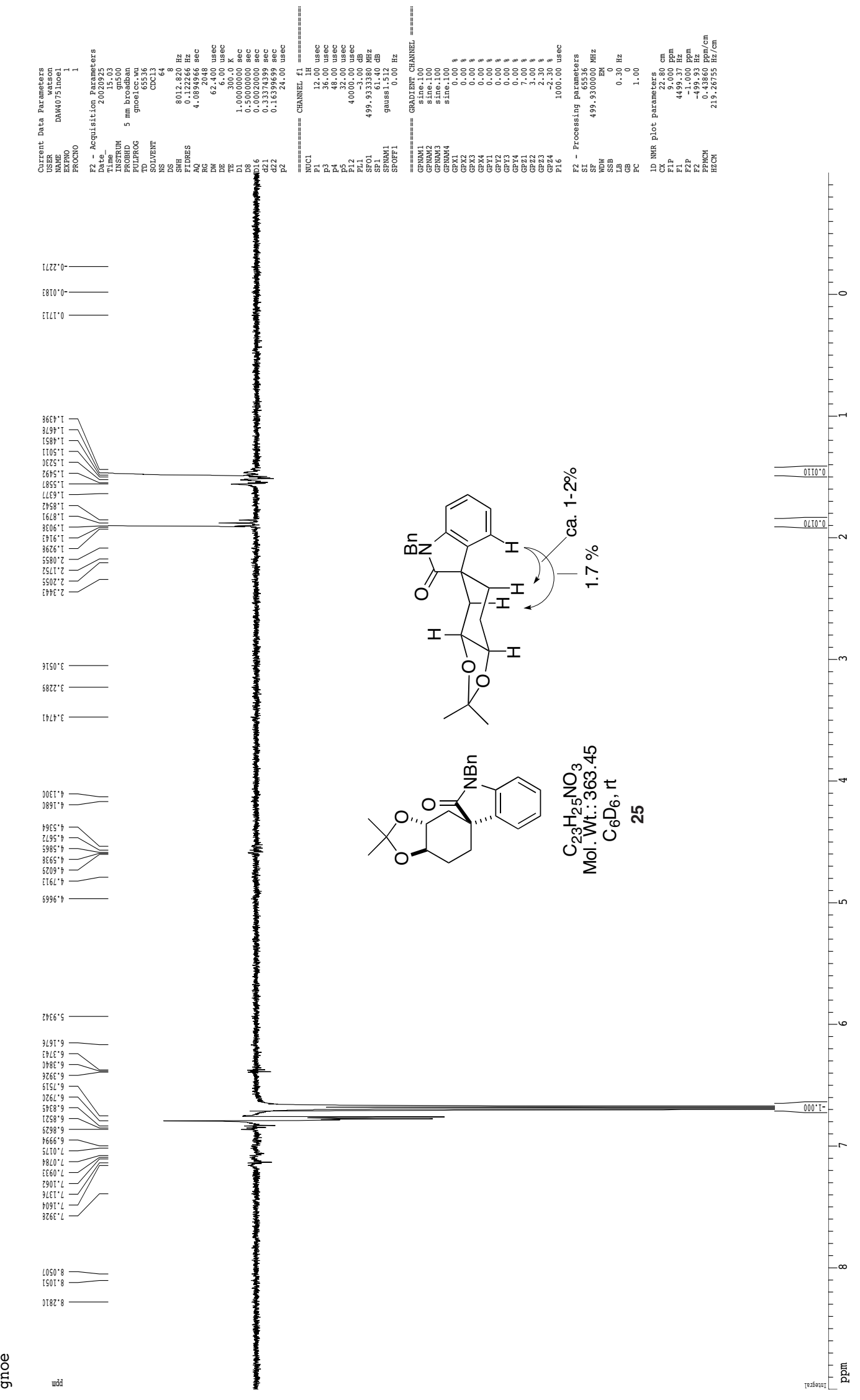



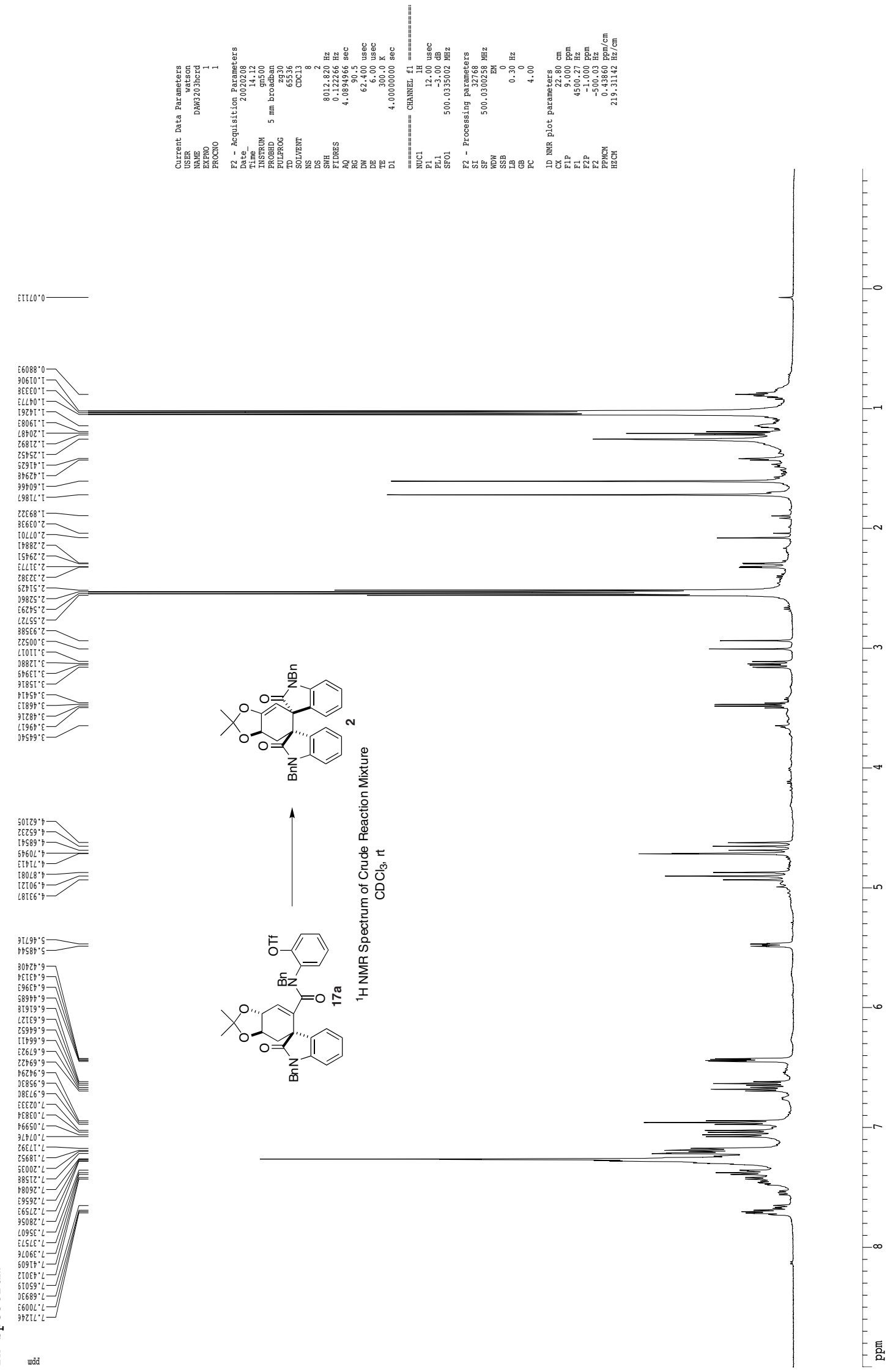
Supporting Information Overman and Watson
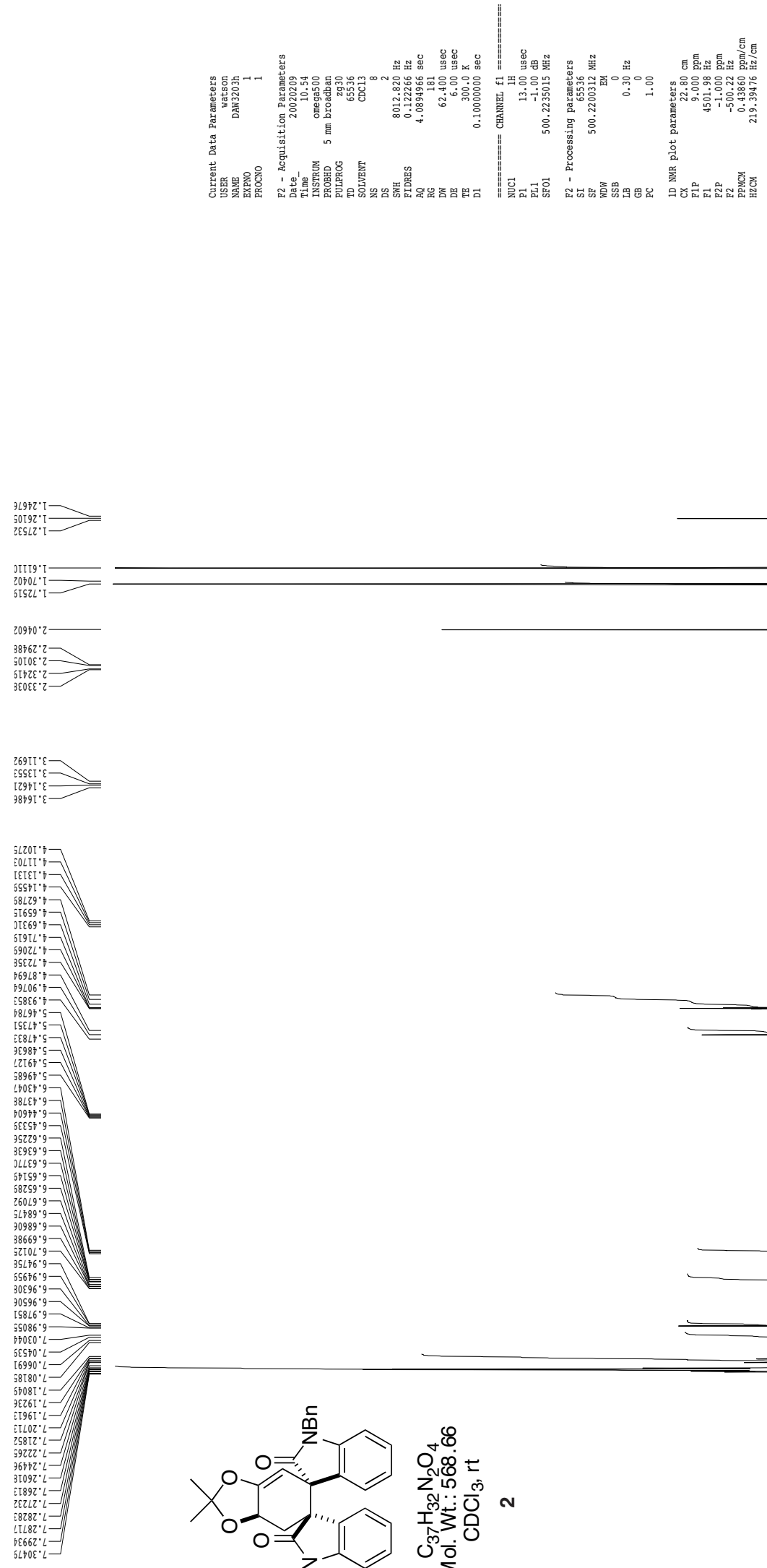

udad
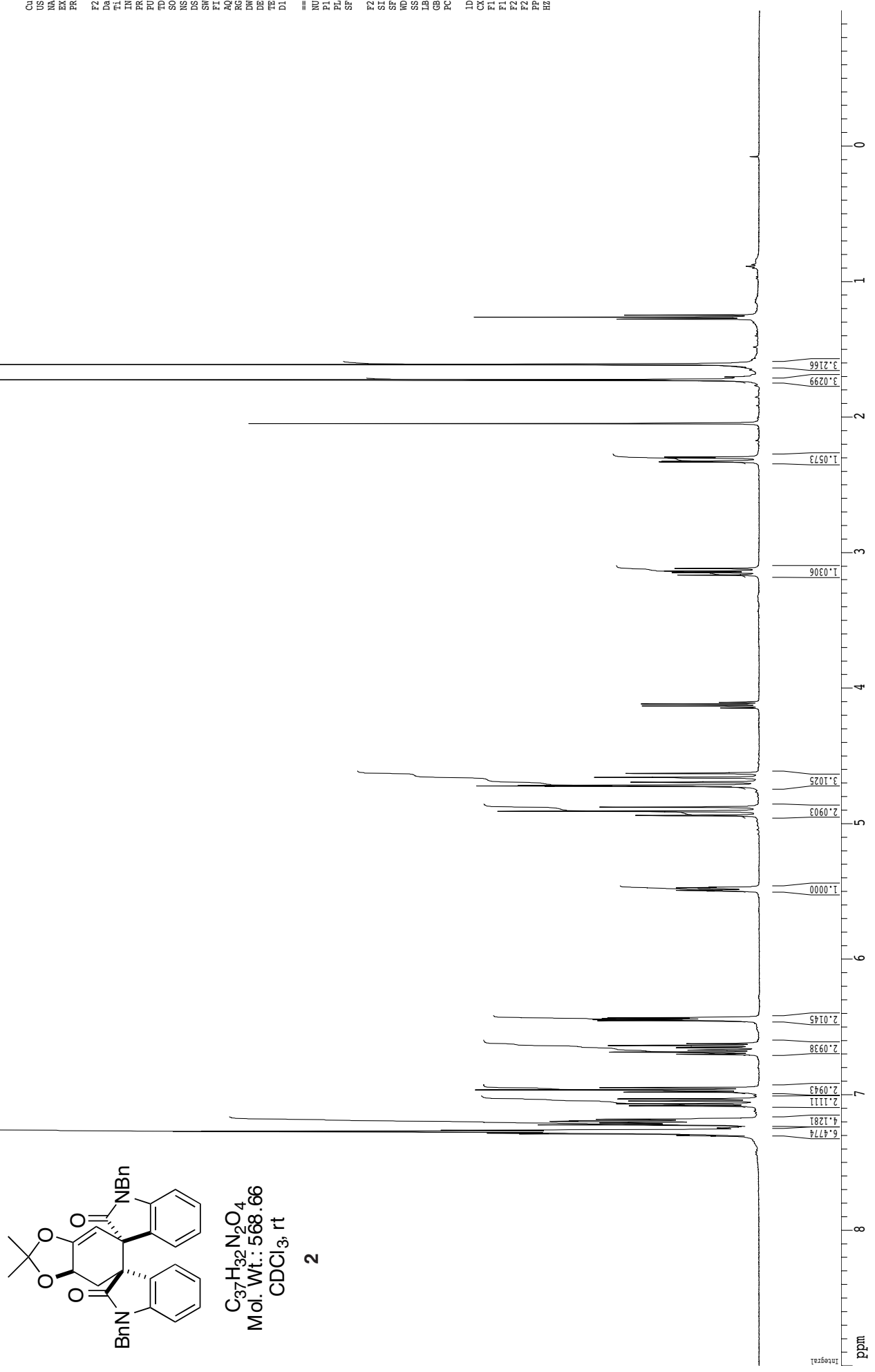

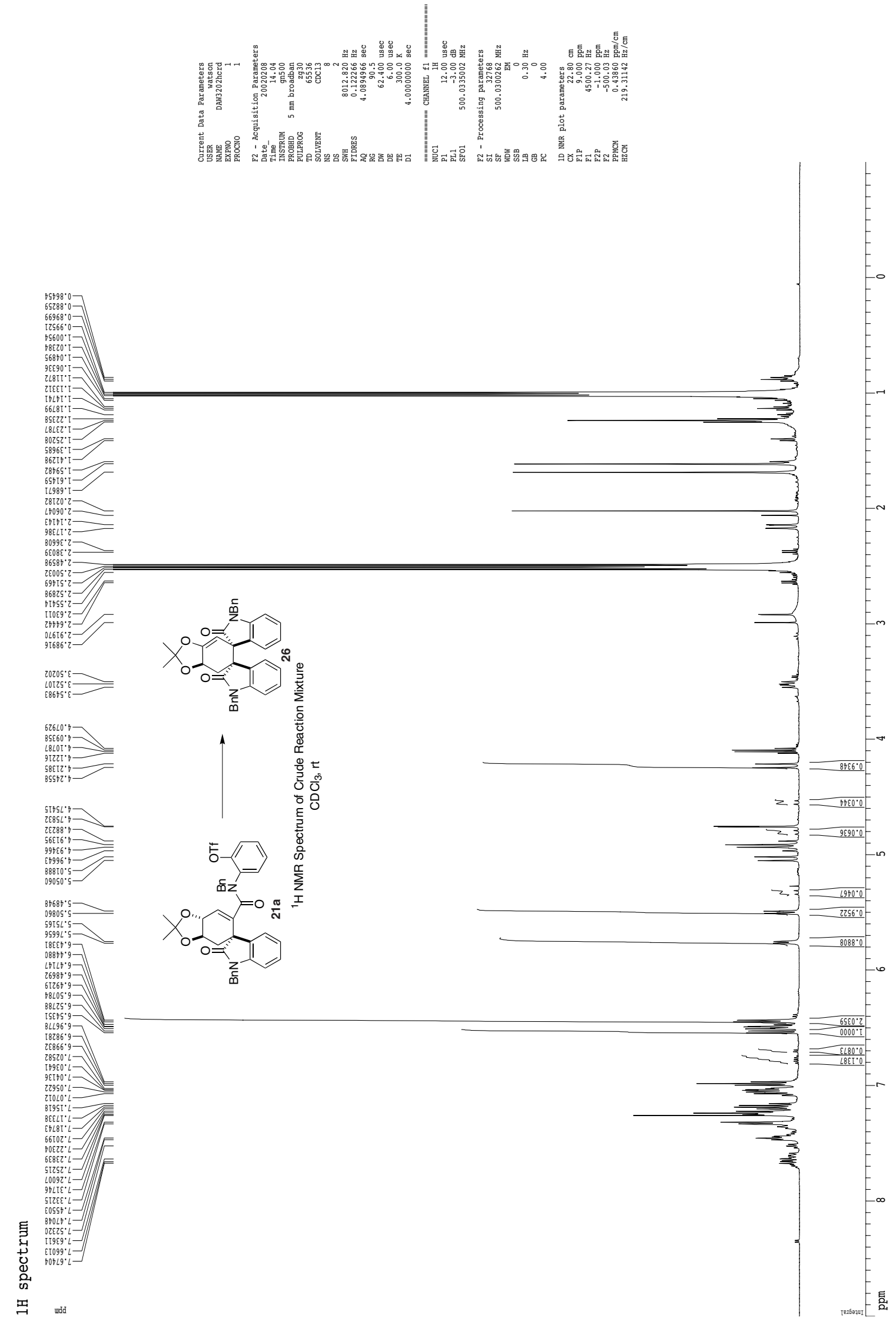
Supporting Information Overman and Watson
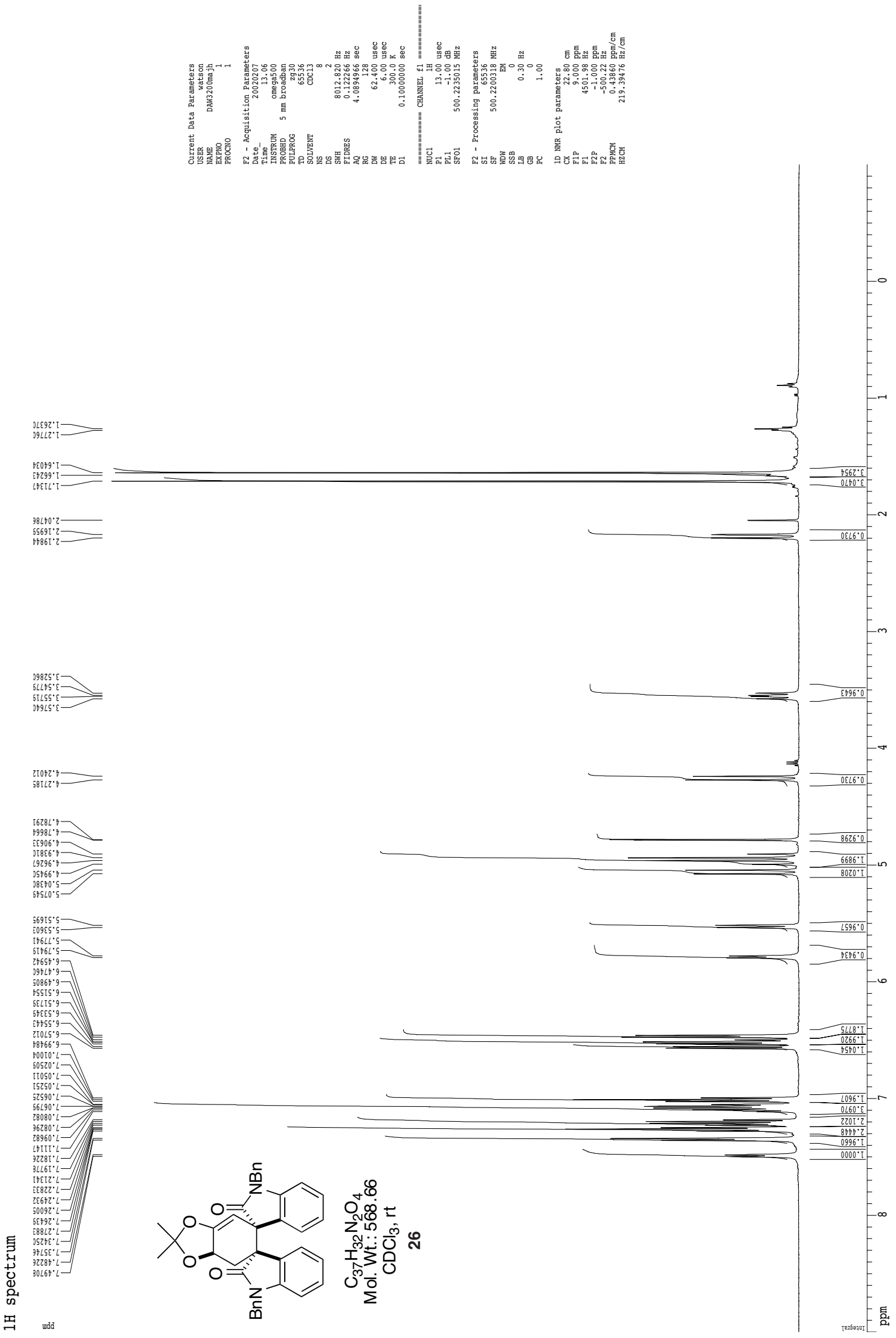

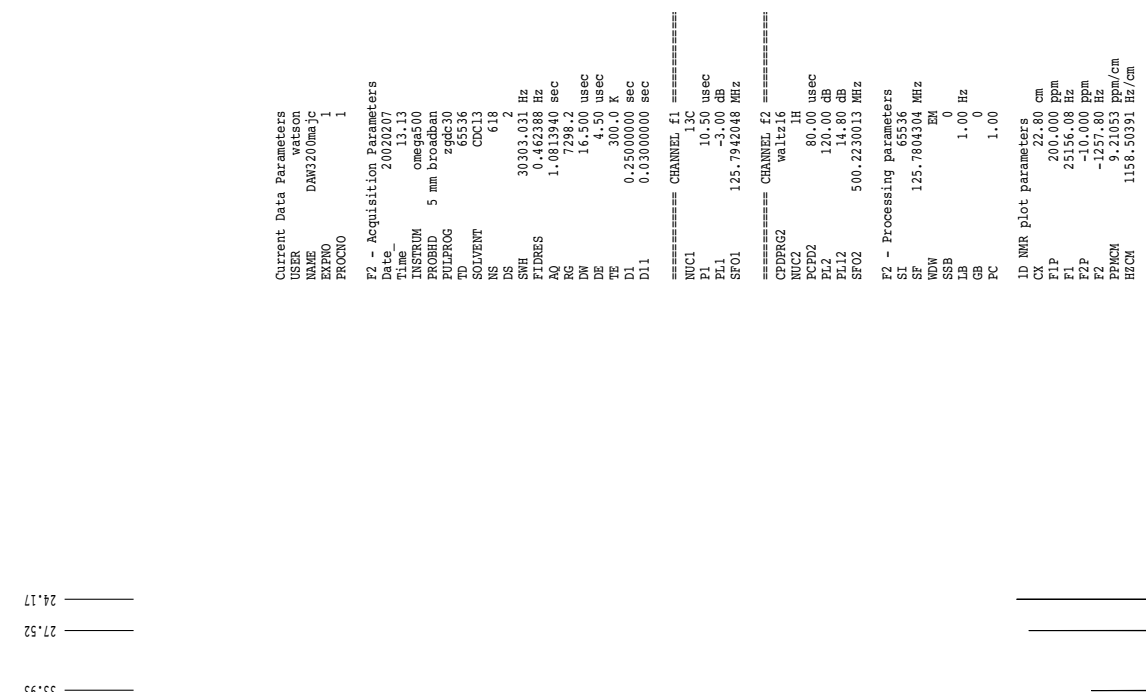

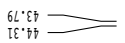

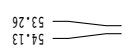

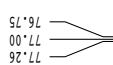

Ib' 26
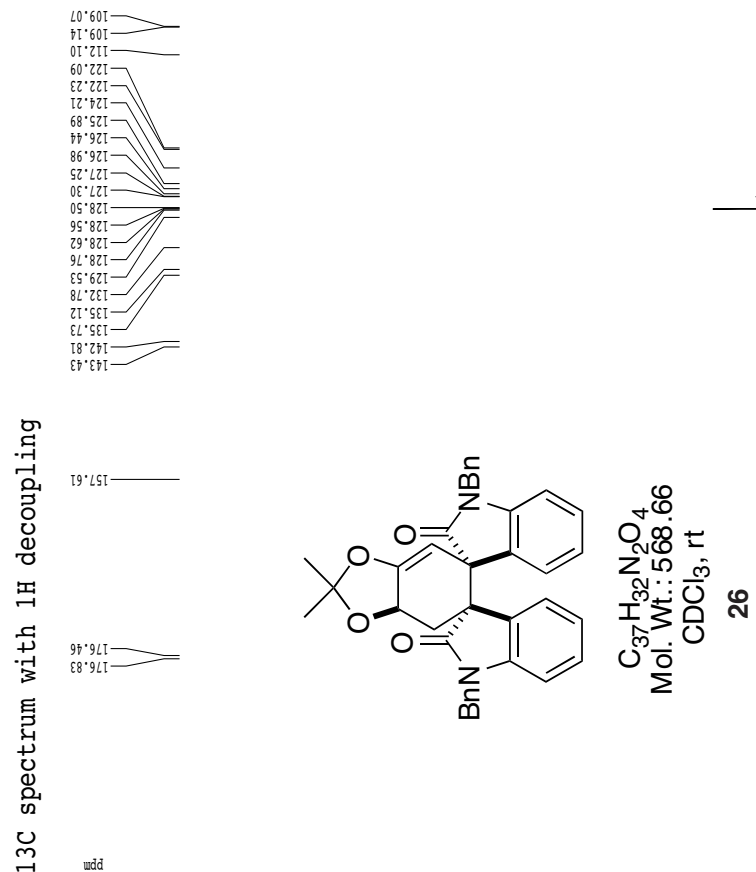
Supporting Information Overman and Watson
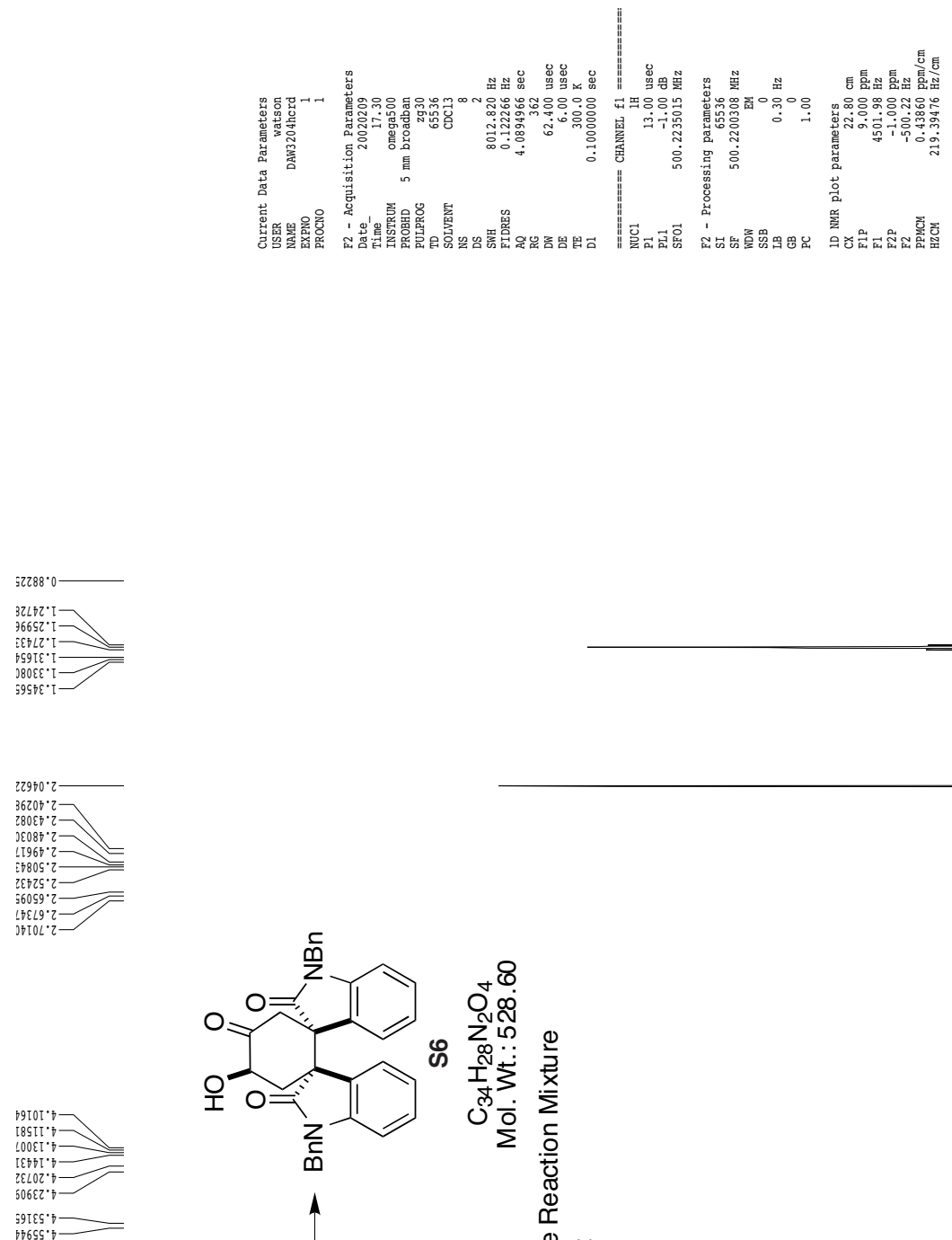

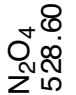

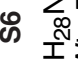

$\stackrel{0}{\sum^{2}}$

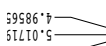

t.toso: 5

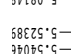

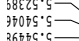

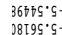

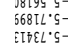

$36660^{\circ} 9-$

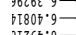

$32660^{9} \cdot 9-7$

$36 \cos \cdot 9$
$69225 \cdot 9]$

$796295^{\circ} 9$

$32815^{\circ} \cdot 9$
$30629^{\circ}$

$59769 \cdot 9-$
$30666.9-$

$30666^{\circ} 9-$
$27666^{\circ} 9$
3

26600.

$5680^{\circ}:-1$

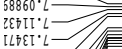

$28667 \cdot 2=$

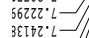

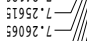

tᄂtLr: $:-$

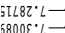

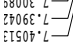
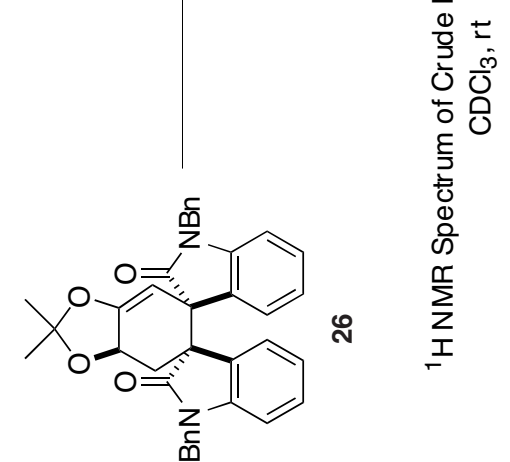

둔

过

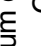

ह
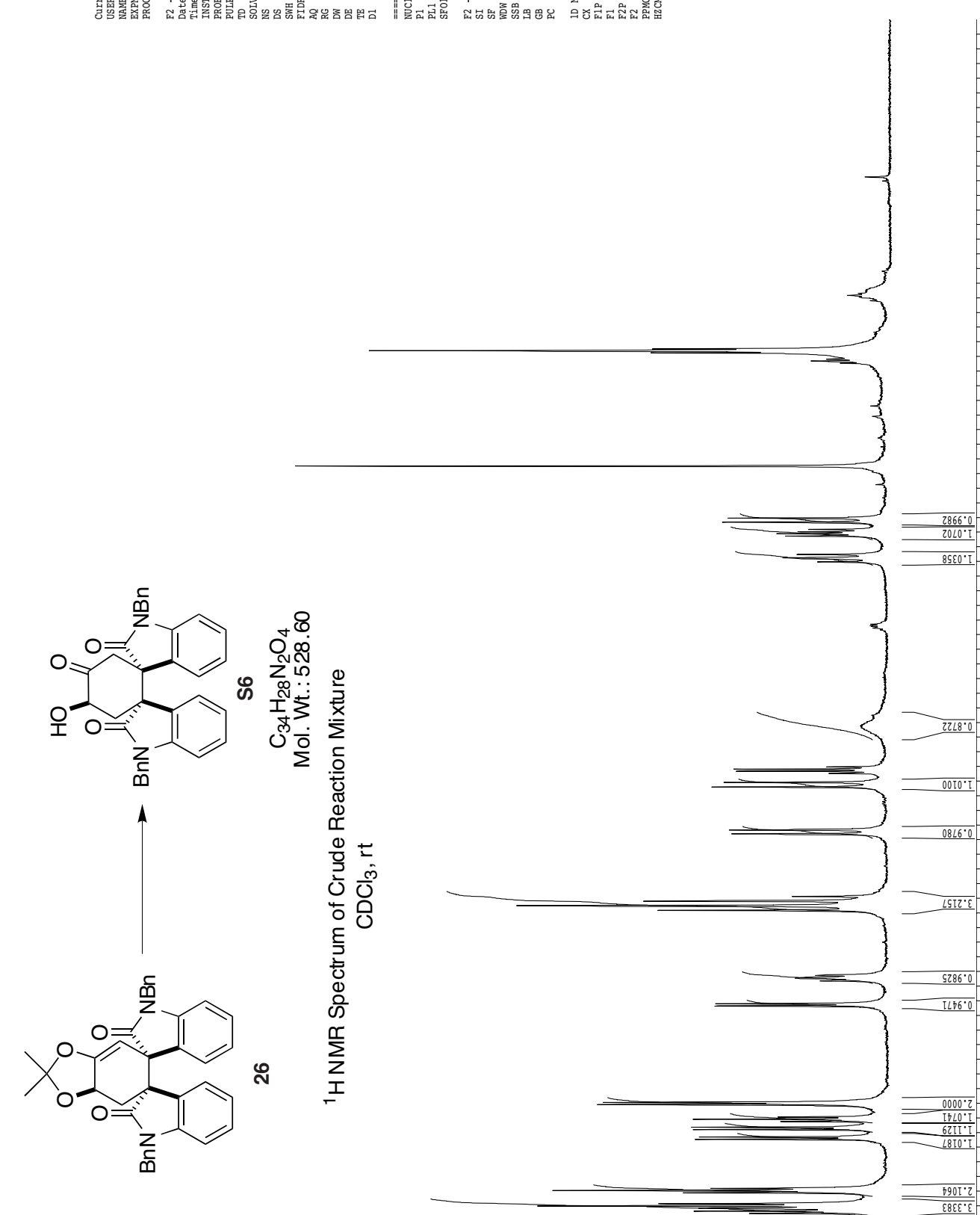


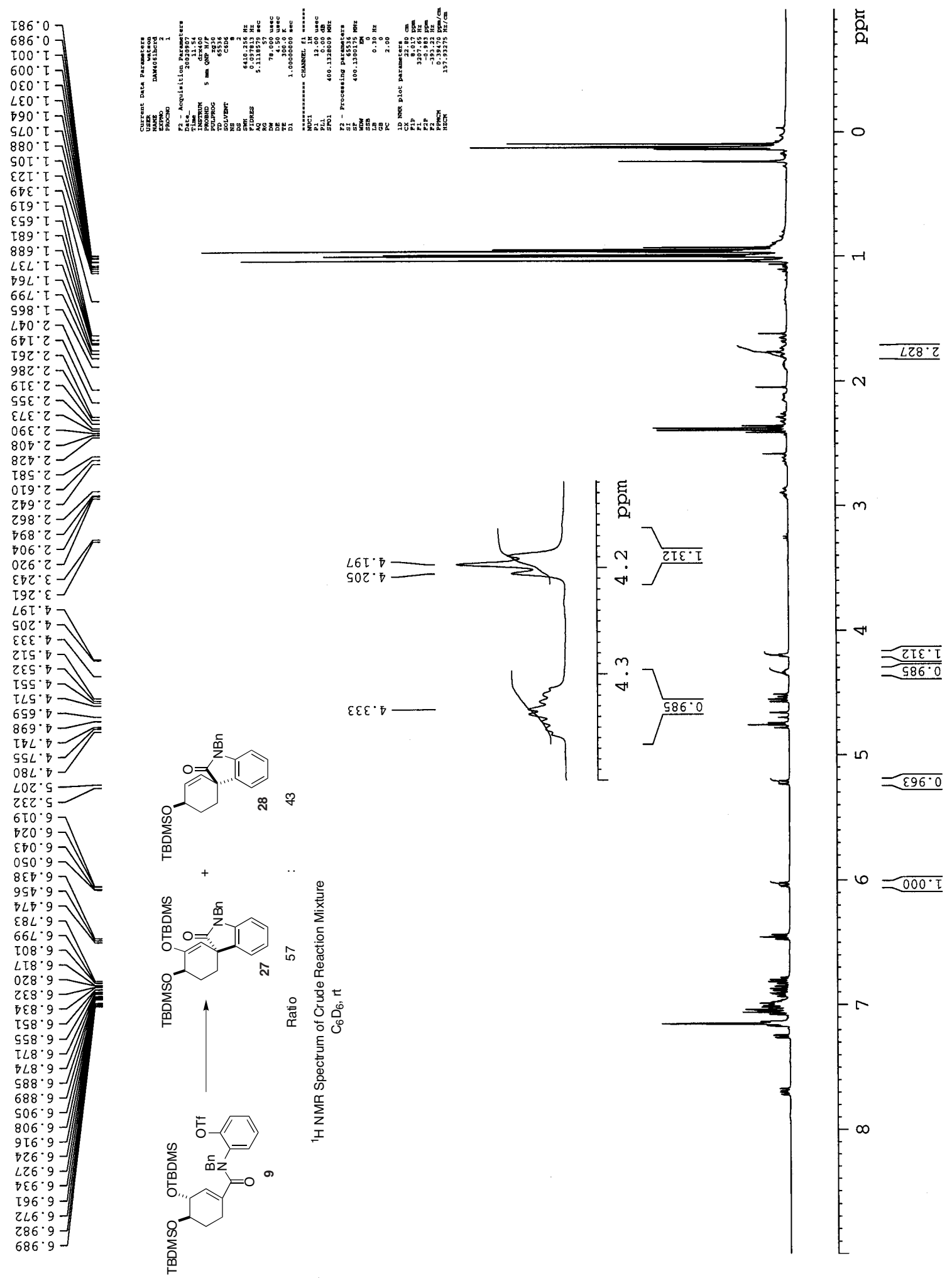




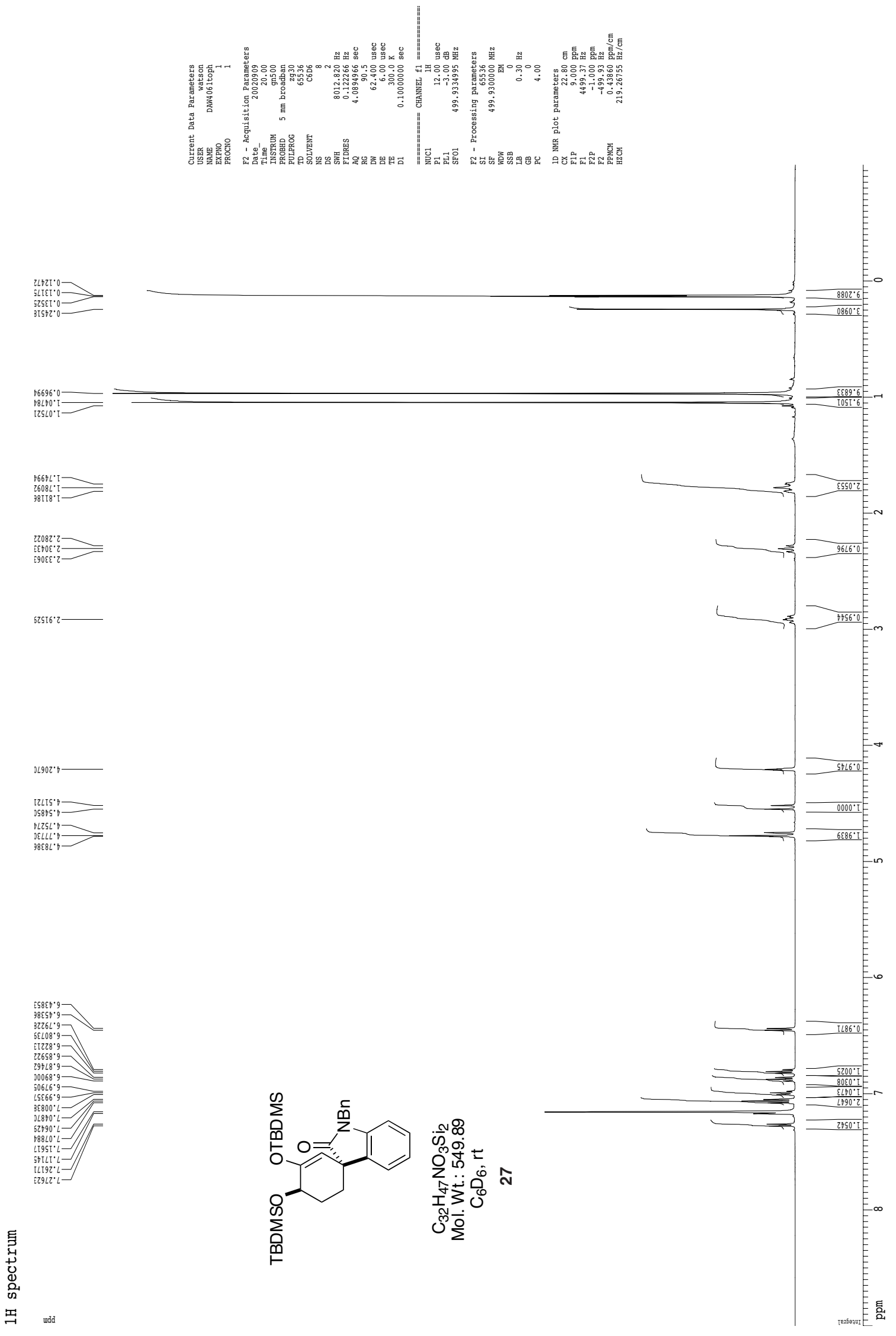


Supporting Information Overman and Watson
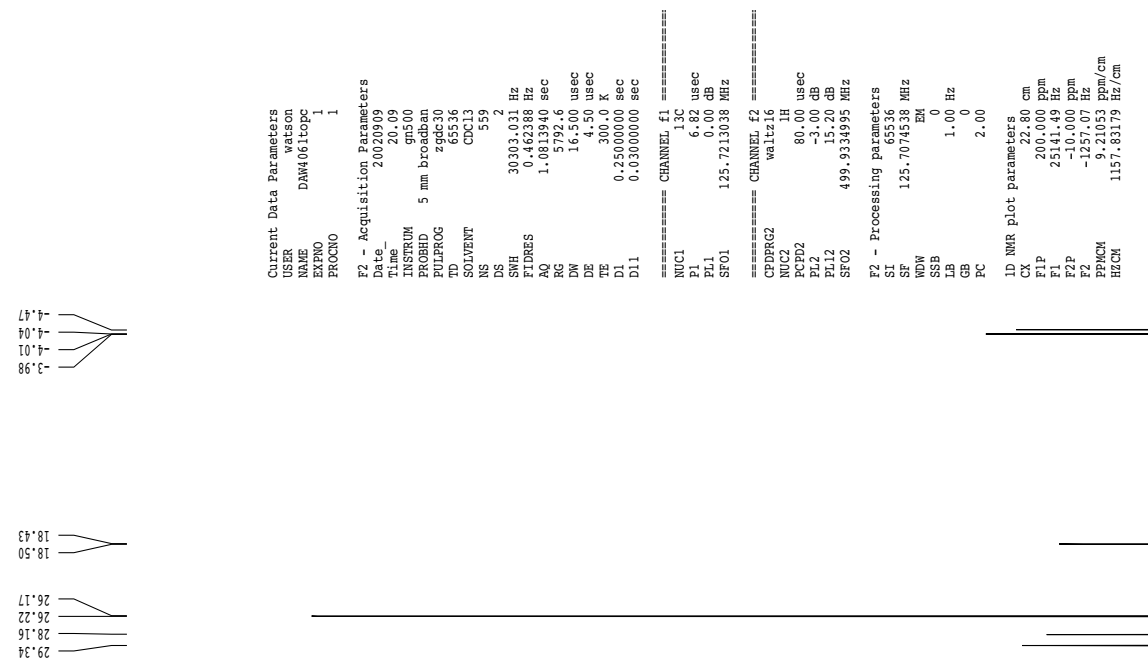

Iร'\&

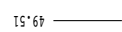

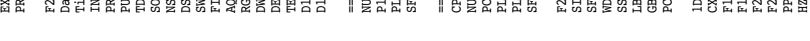
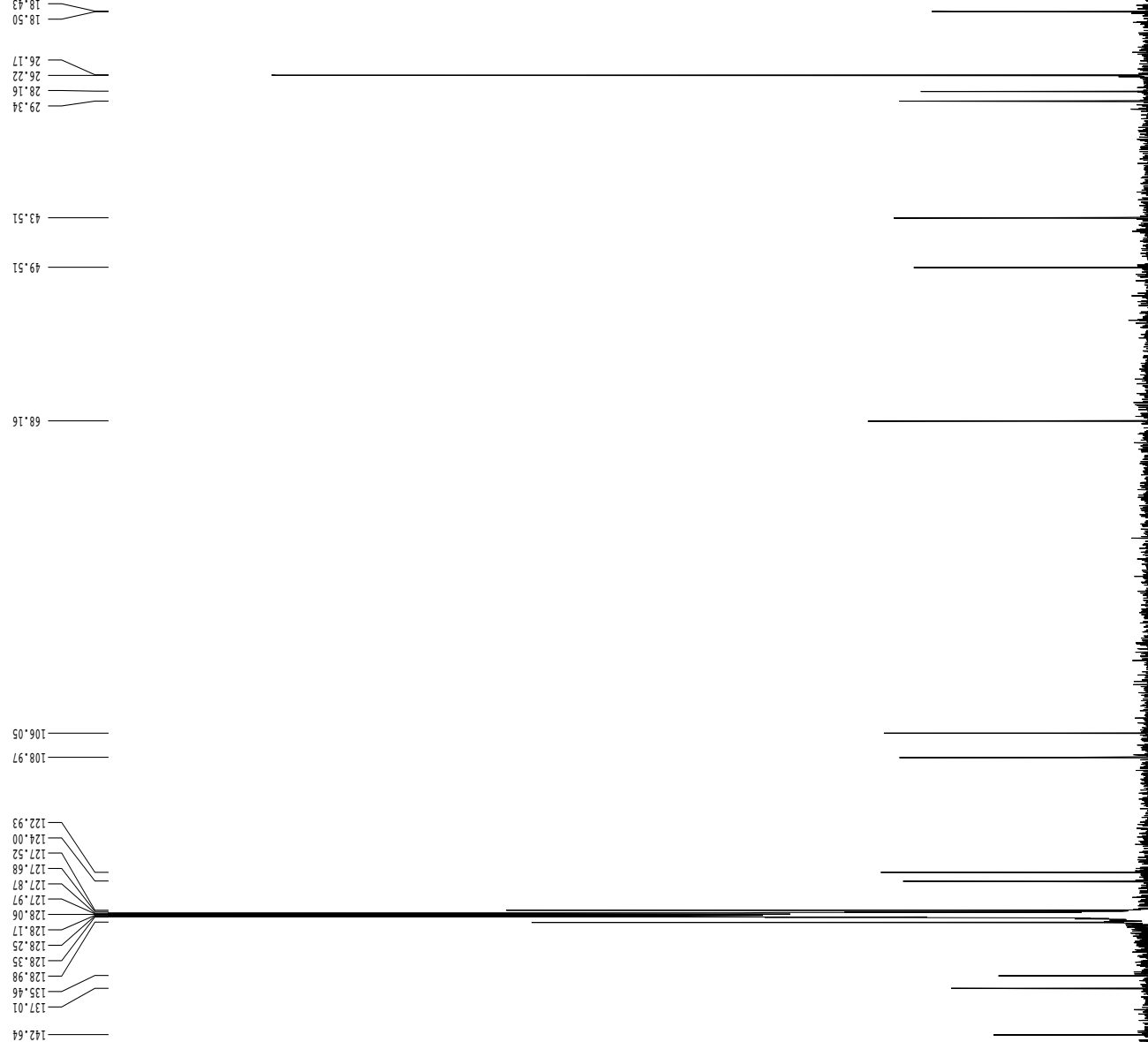

79: $27 \mathrm{~T}$
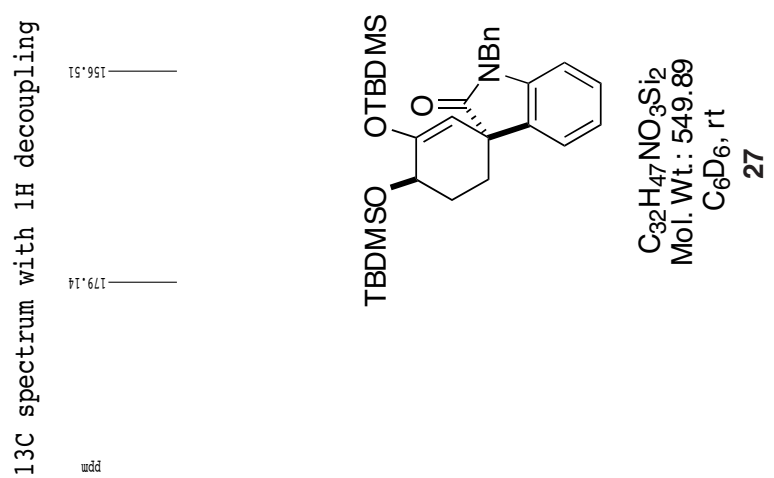


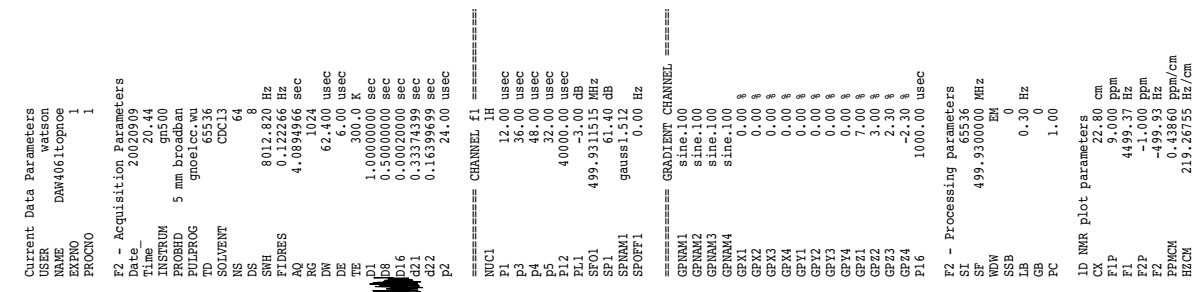

$999 L^{\circ} 0-$

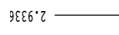

$556 \top^{\circ} \varepsilon$

9tul.
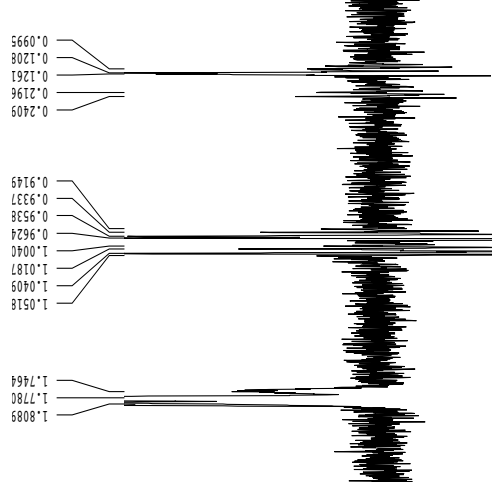

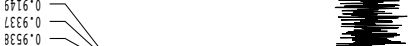

${ }^{8296^{\circ}} \mathrm{O}=$

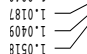

9

${ }^{298 \tau^{\circ} \cdot \mathrm{L}} \mathrm{C}$
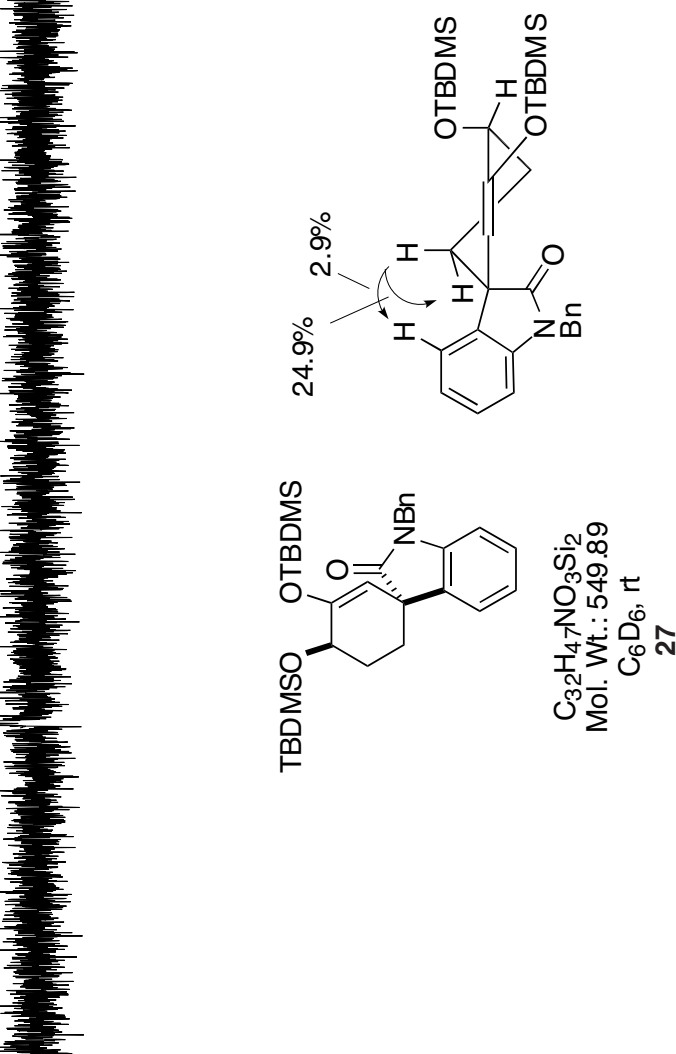
Supporting Information Overman and Watson
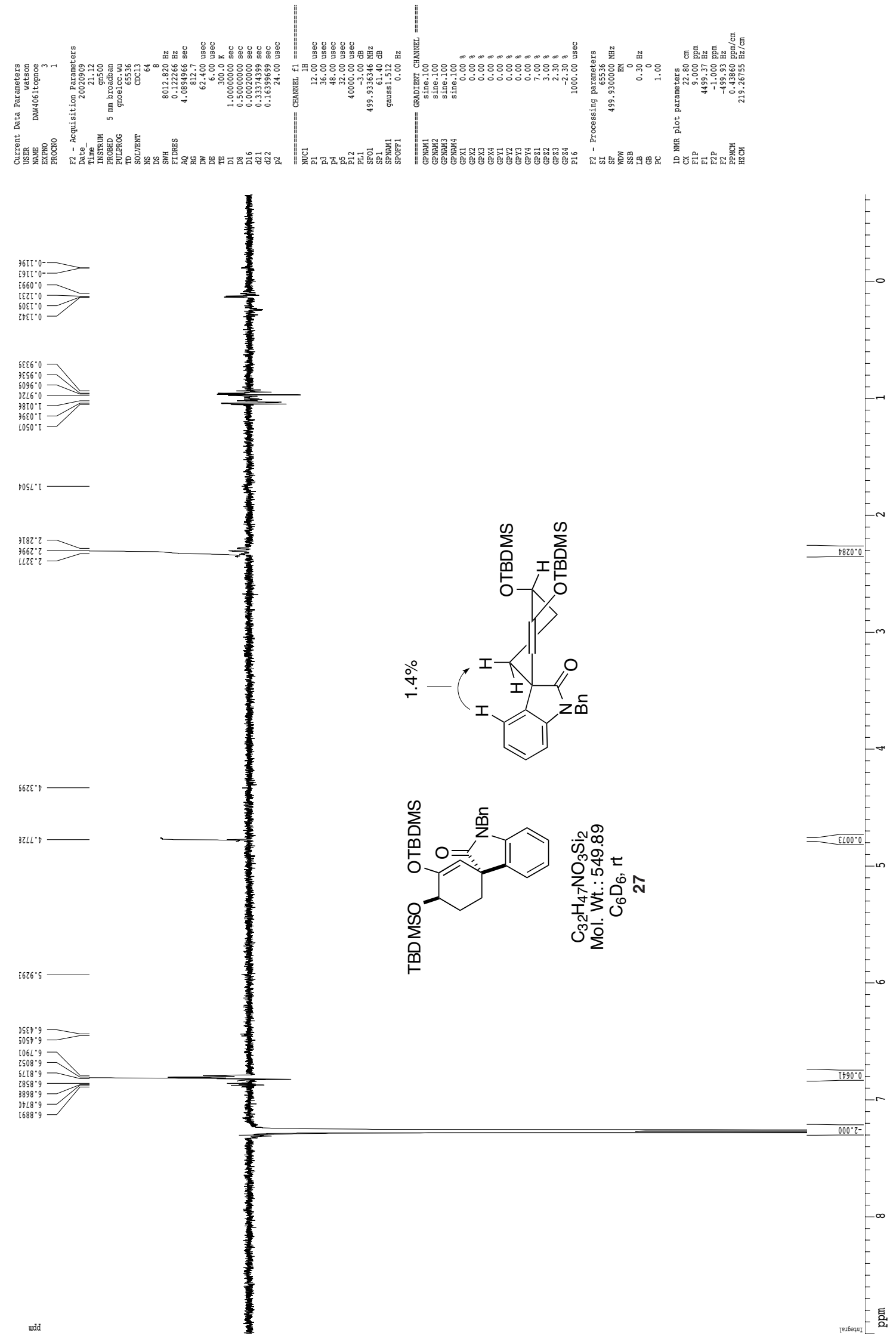

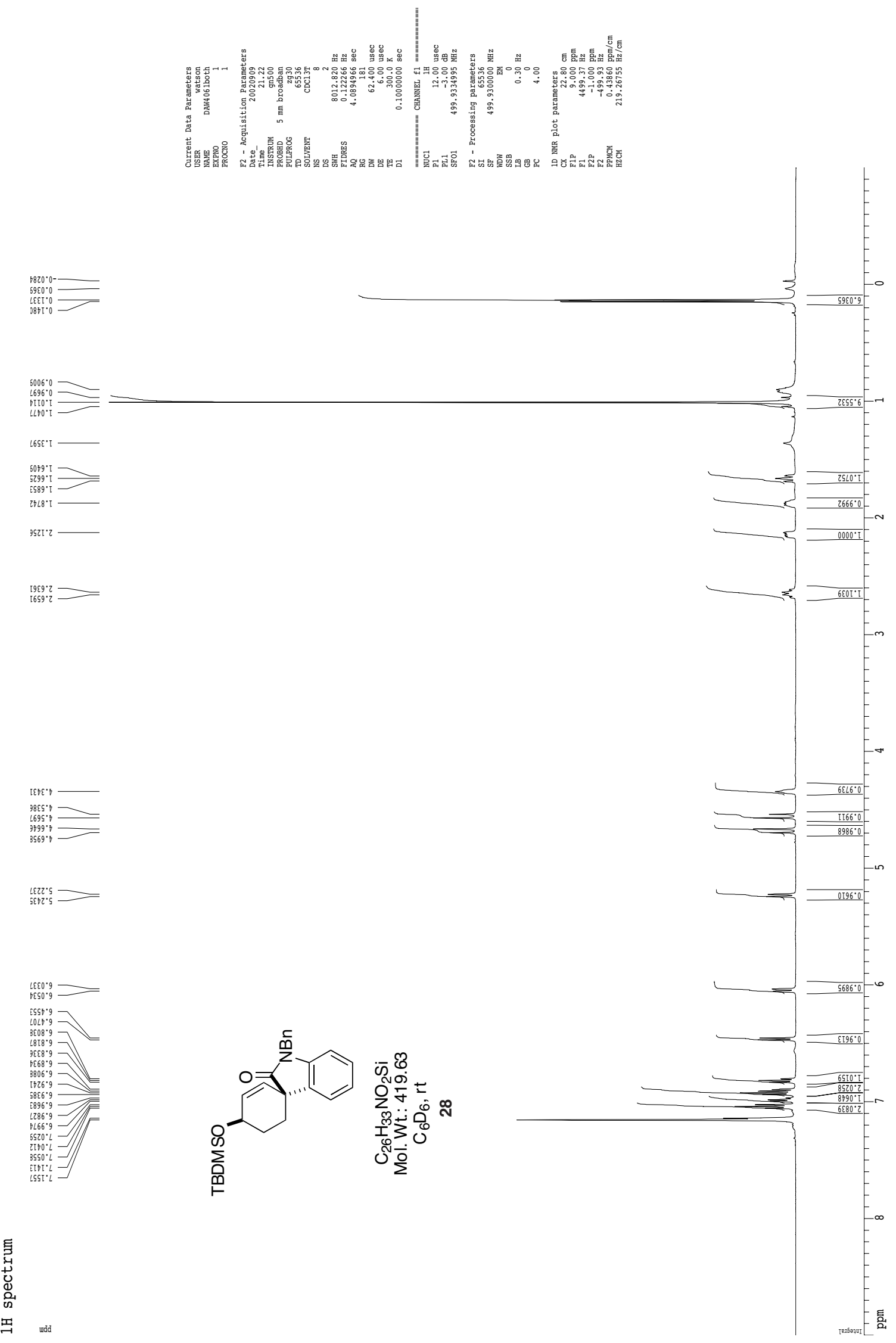


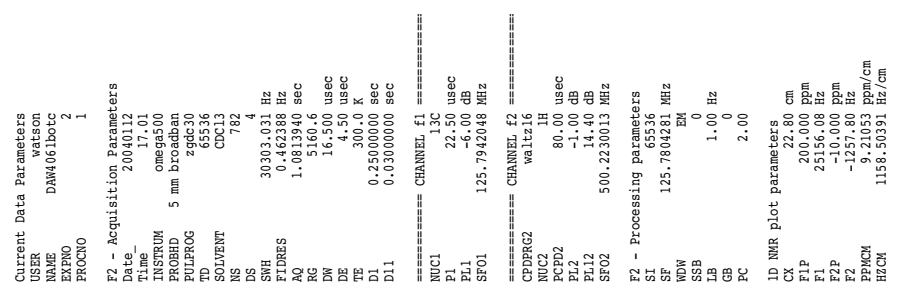

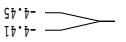

$8 I^{\circ} 8 \mathrm{~T}$

$\varepsilon 8^{\circ} \varsigma \mathrm{C}$
$88^{\circ} \varsigma 2$
$89^{\circ} .82=$
$9 \varepsilon^{\circ} 0 \varepsilon=$

$Z L \cdot \varepsilon t-$
70.67

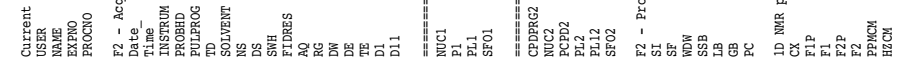
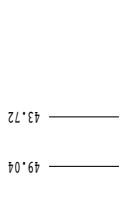

66.59

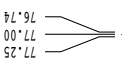

L6'80I
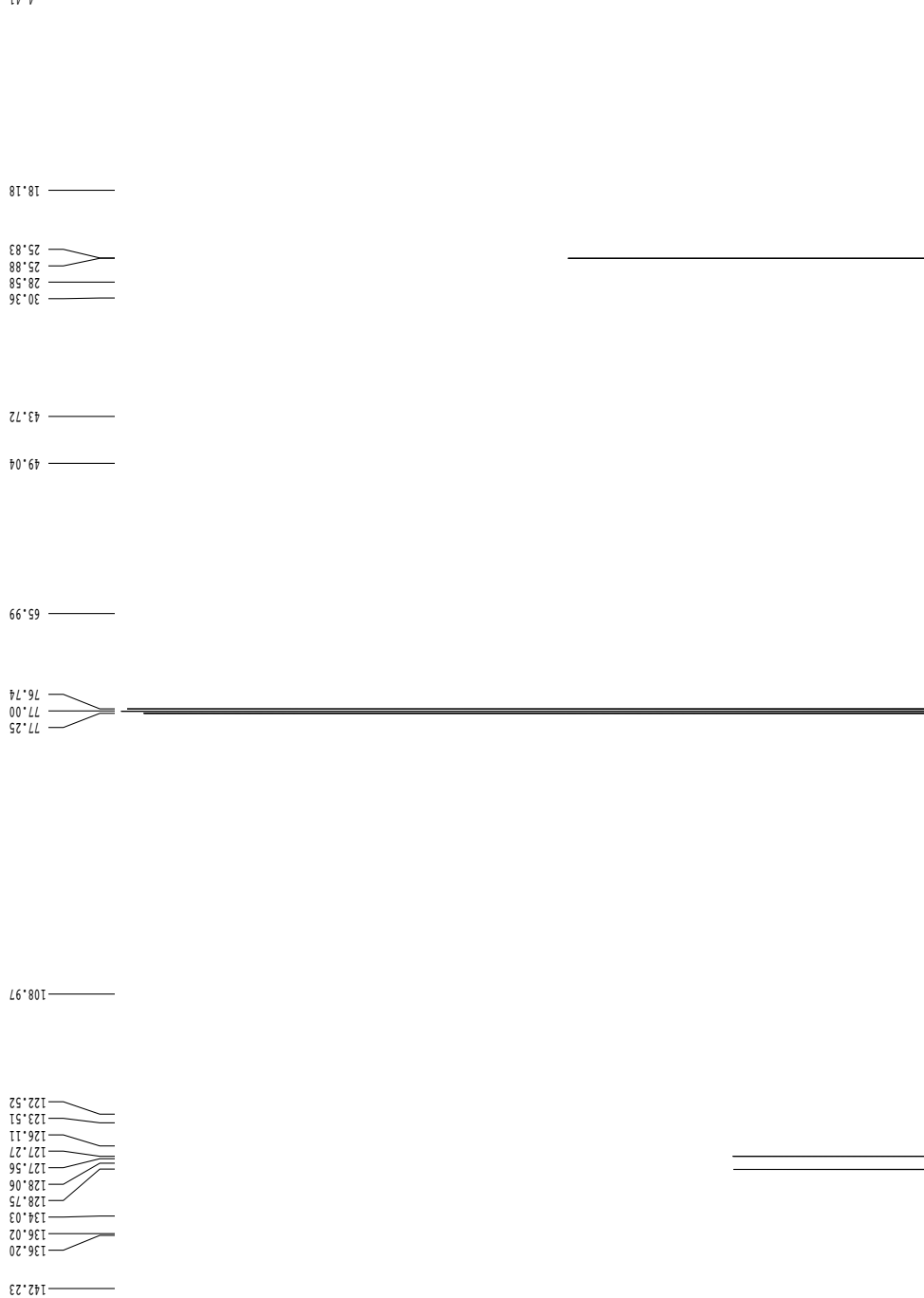


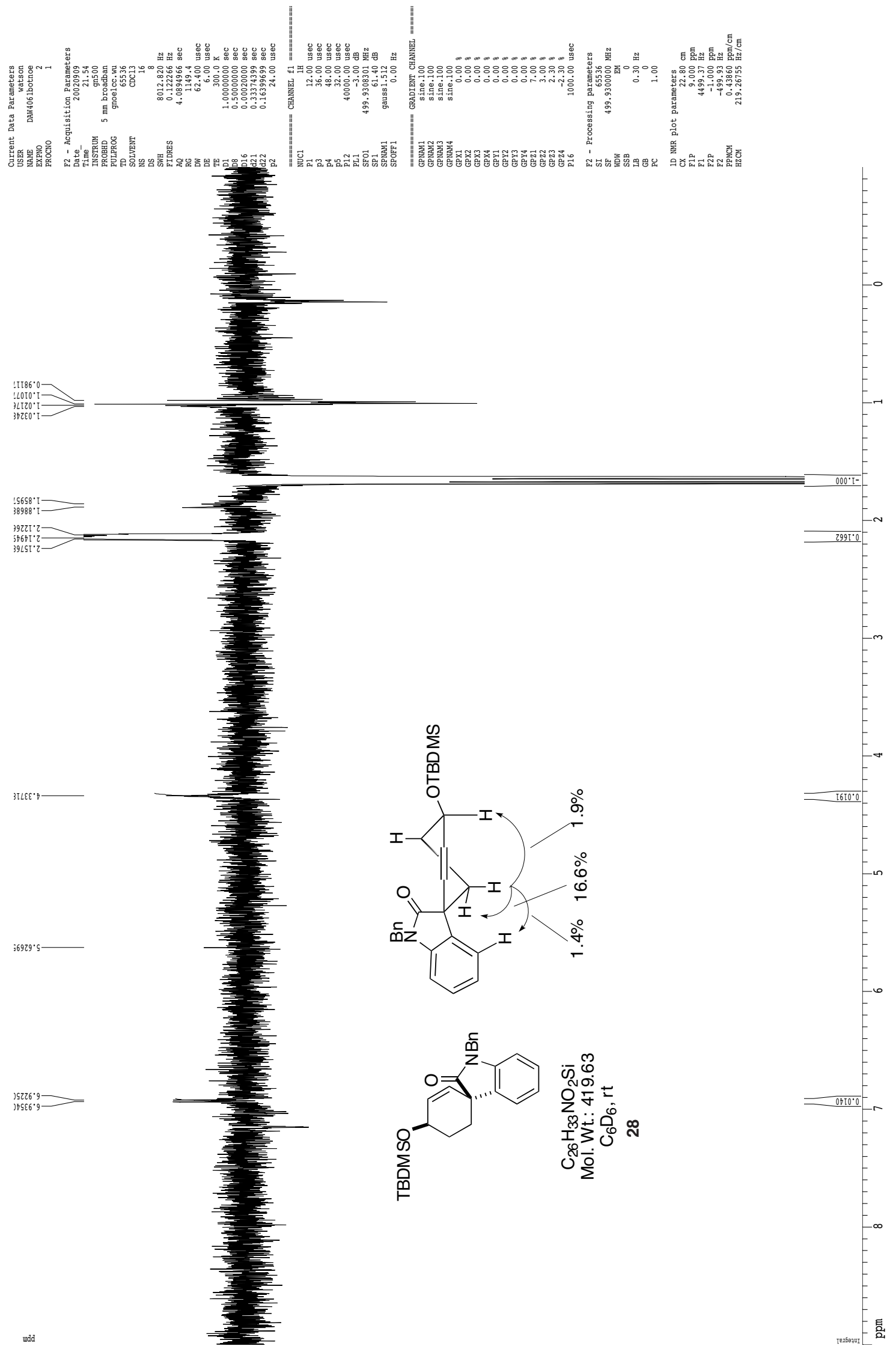




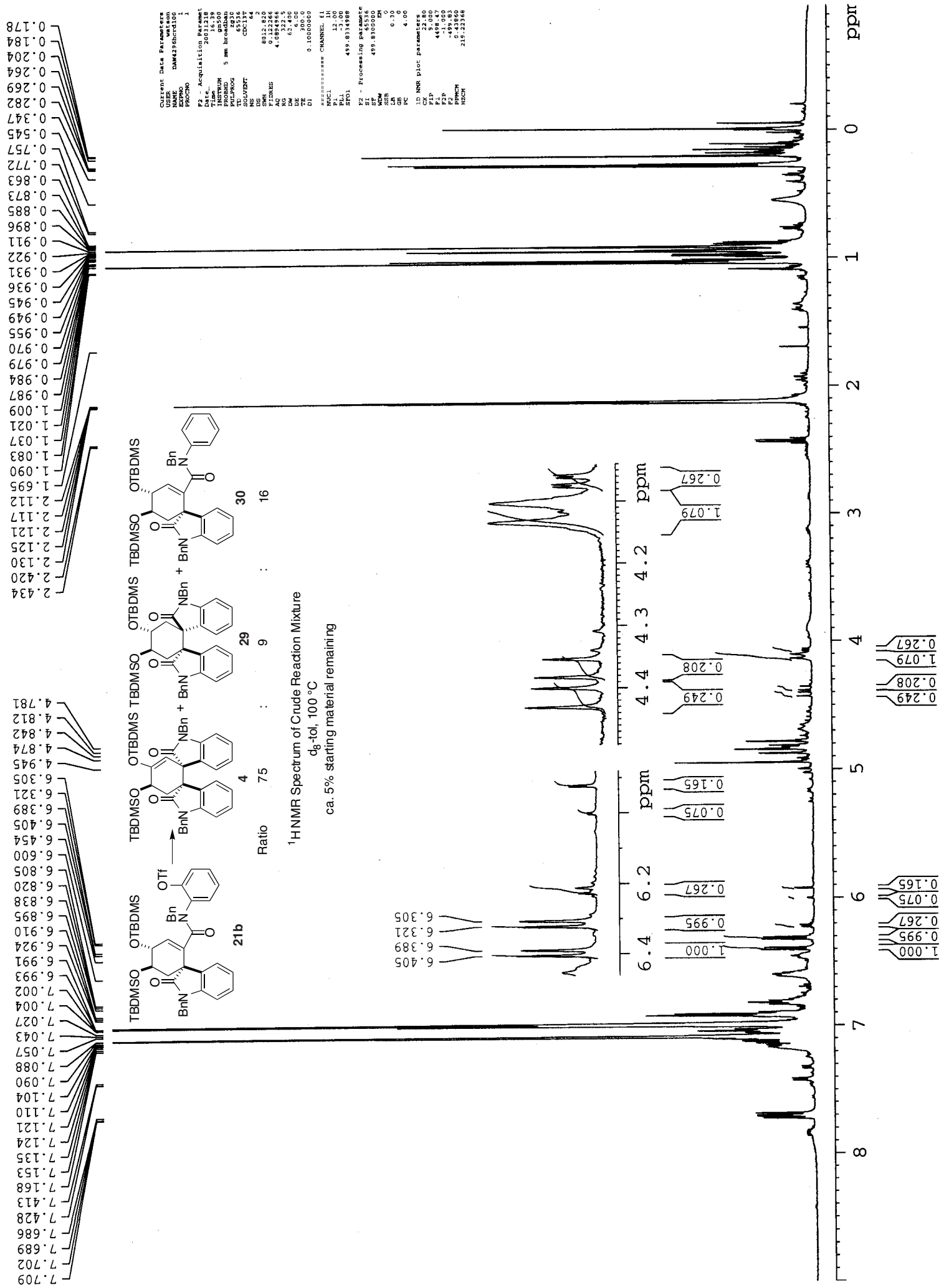




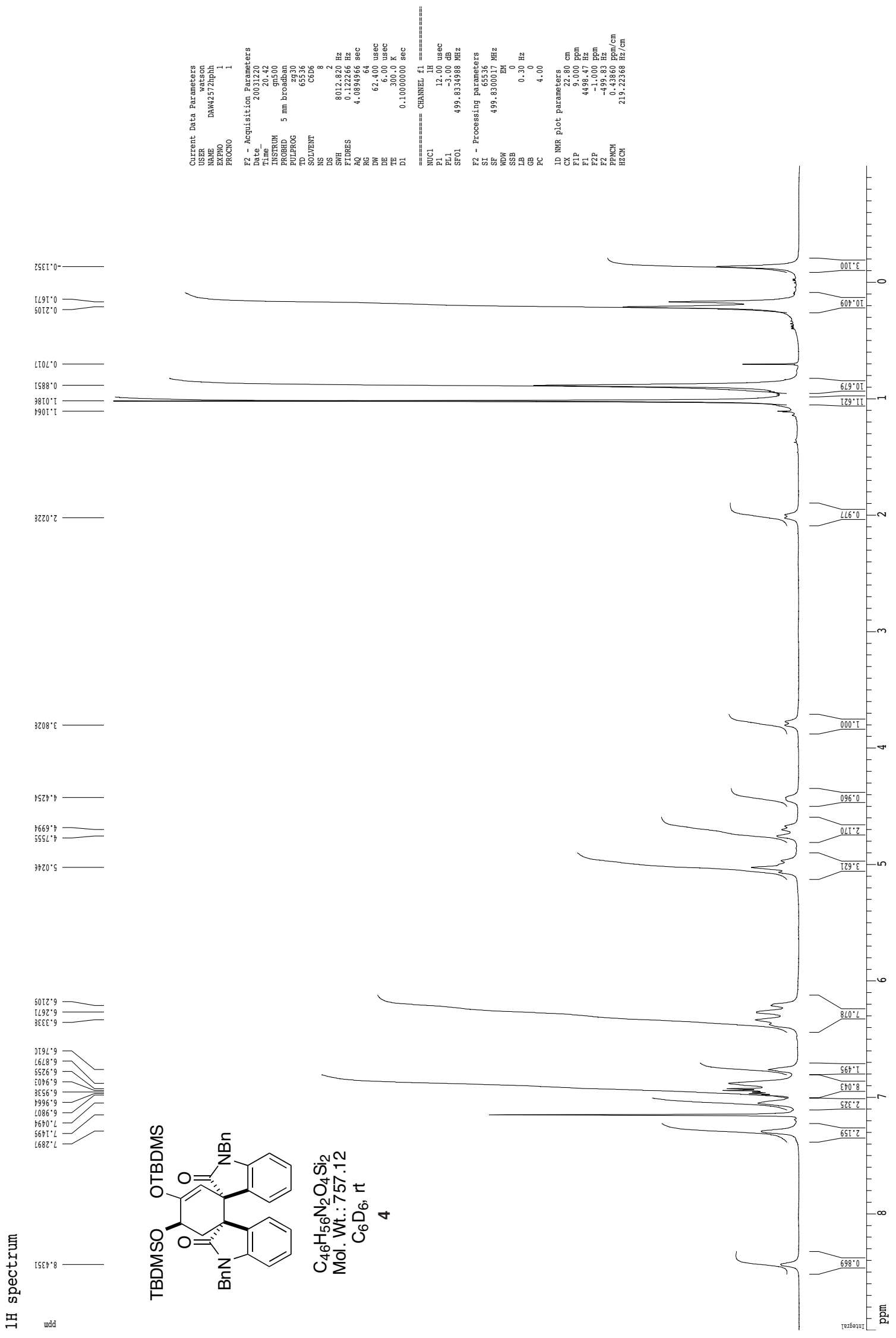




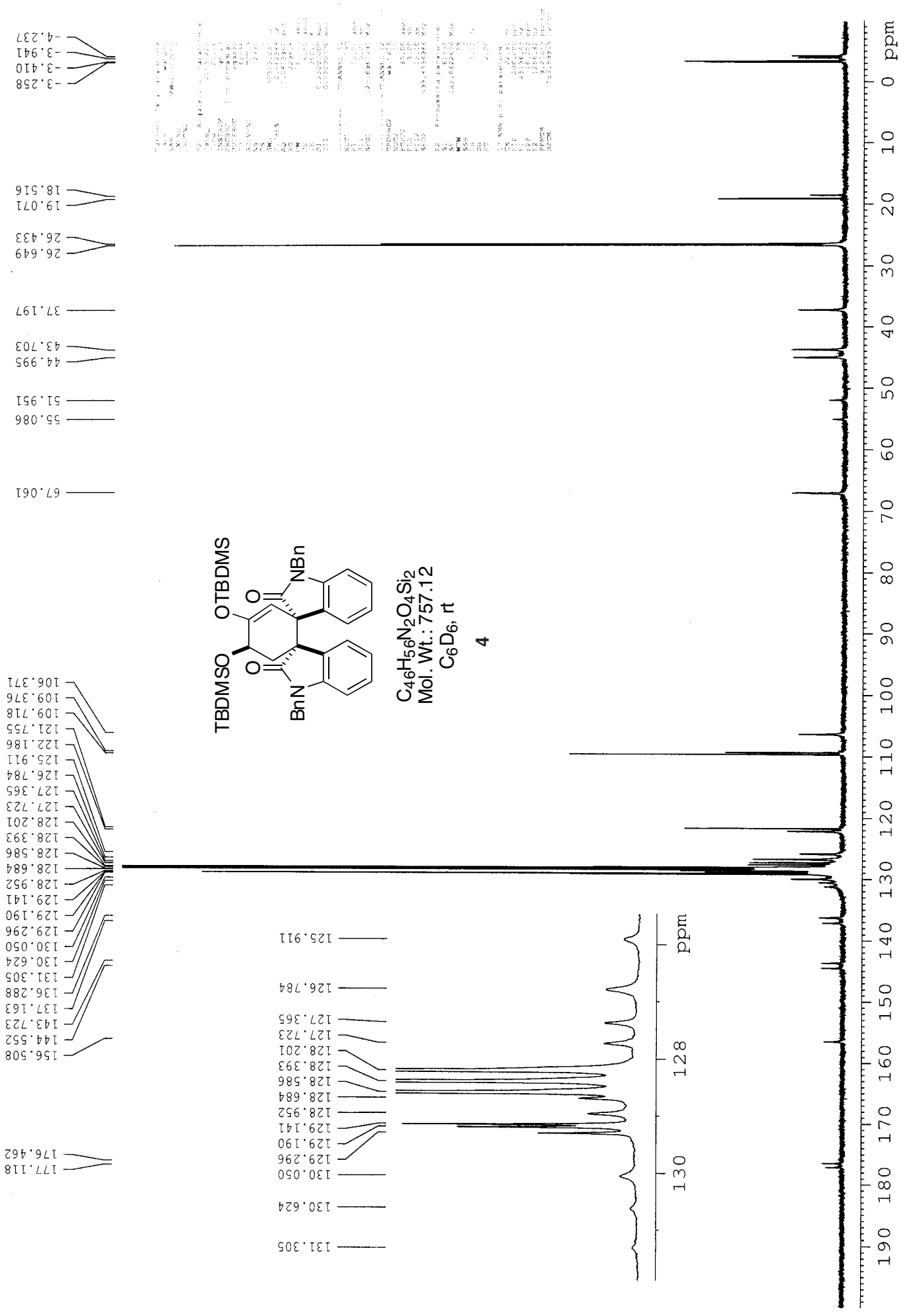


Supporting Information Overman and Watson

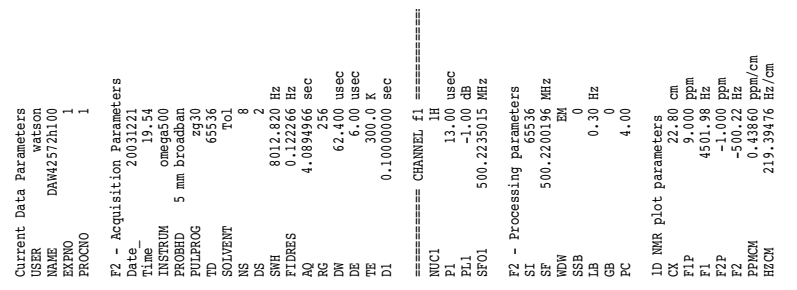

$2060^{\circ} 2$

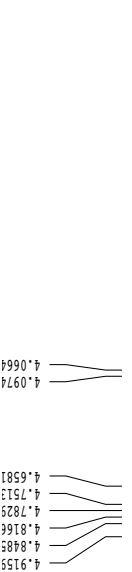

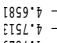

$228 L^{\circ} \mathrm{T}$

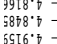

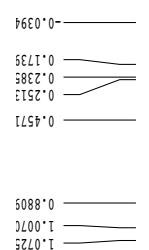

$6 \varepsilon\left(r^{\circ} \cdot 9\right.$
$588 \tau^{\circ} \cdot 9$

$385 \varepsilon^{\circ} \cdot 9$

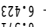

5SLL' 9

$1066 \cdot 9$

$3508 \cdot 9$

$1668.9=$

: 696.9

$6266^{\circ} 9$

IL200.'

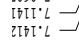

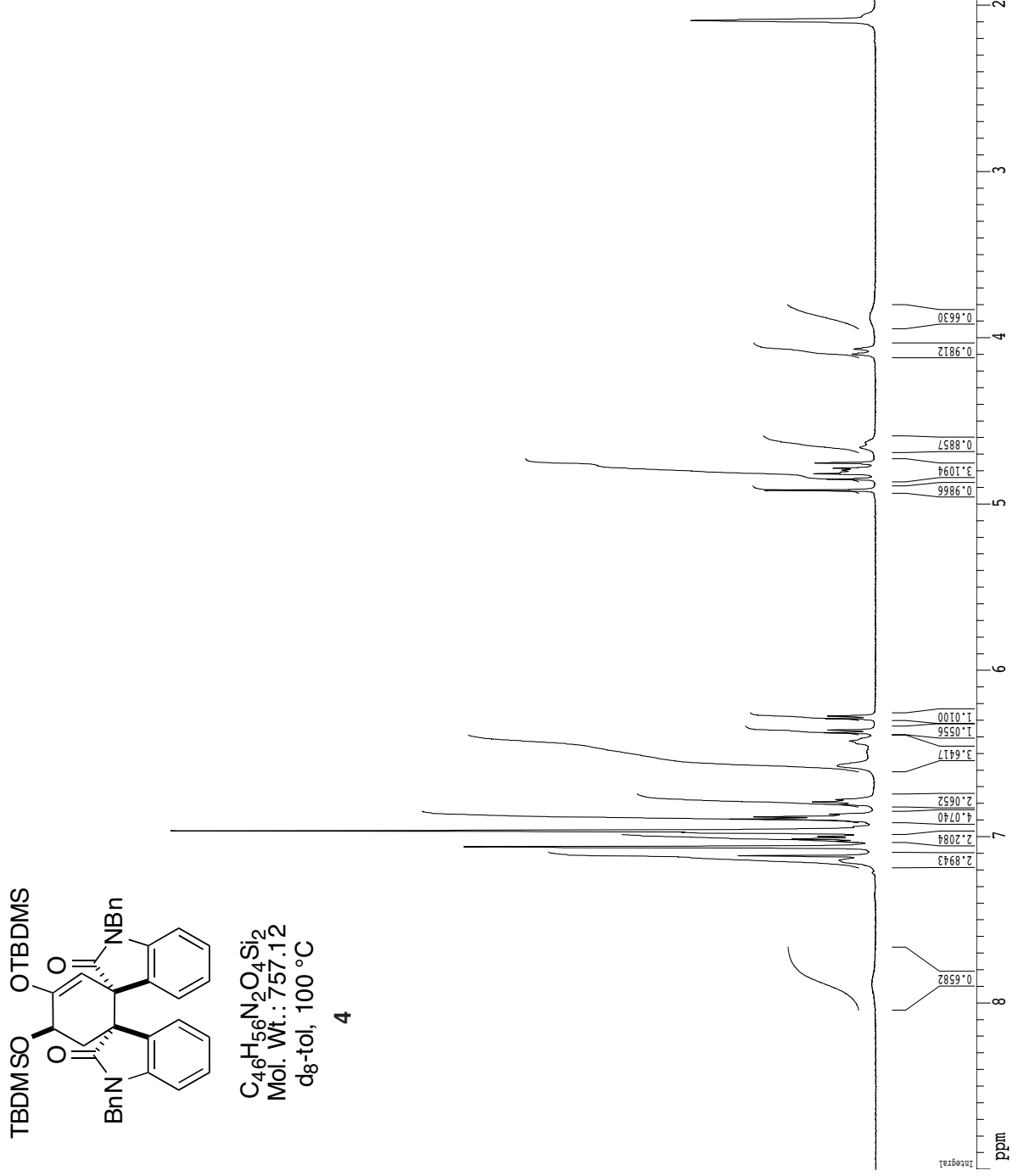

udd 


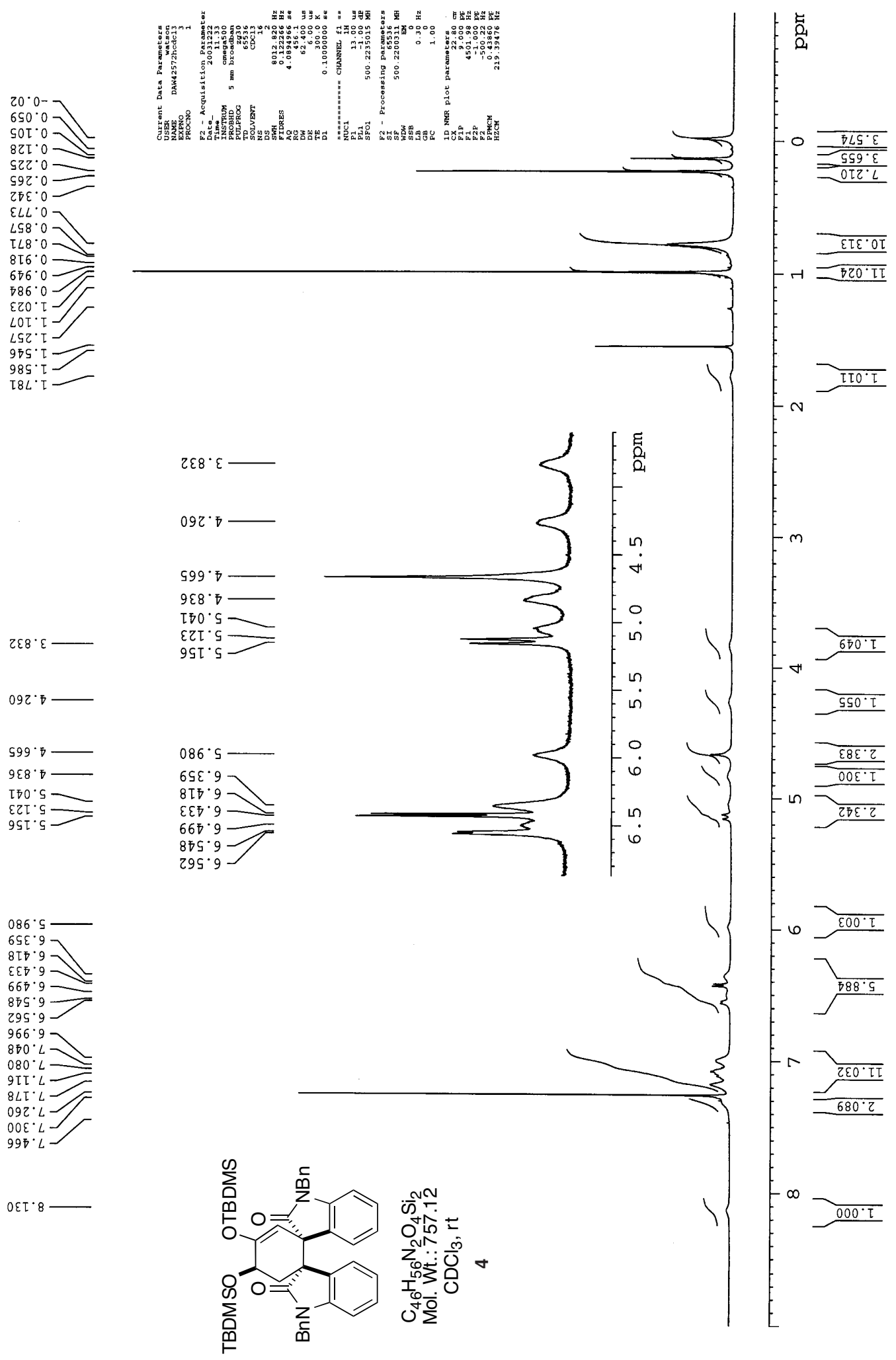




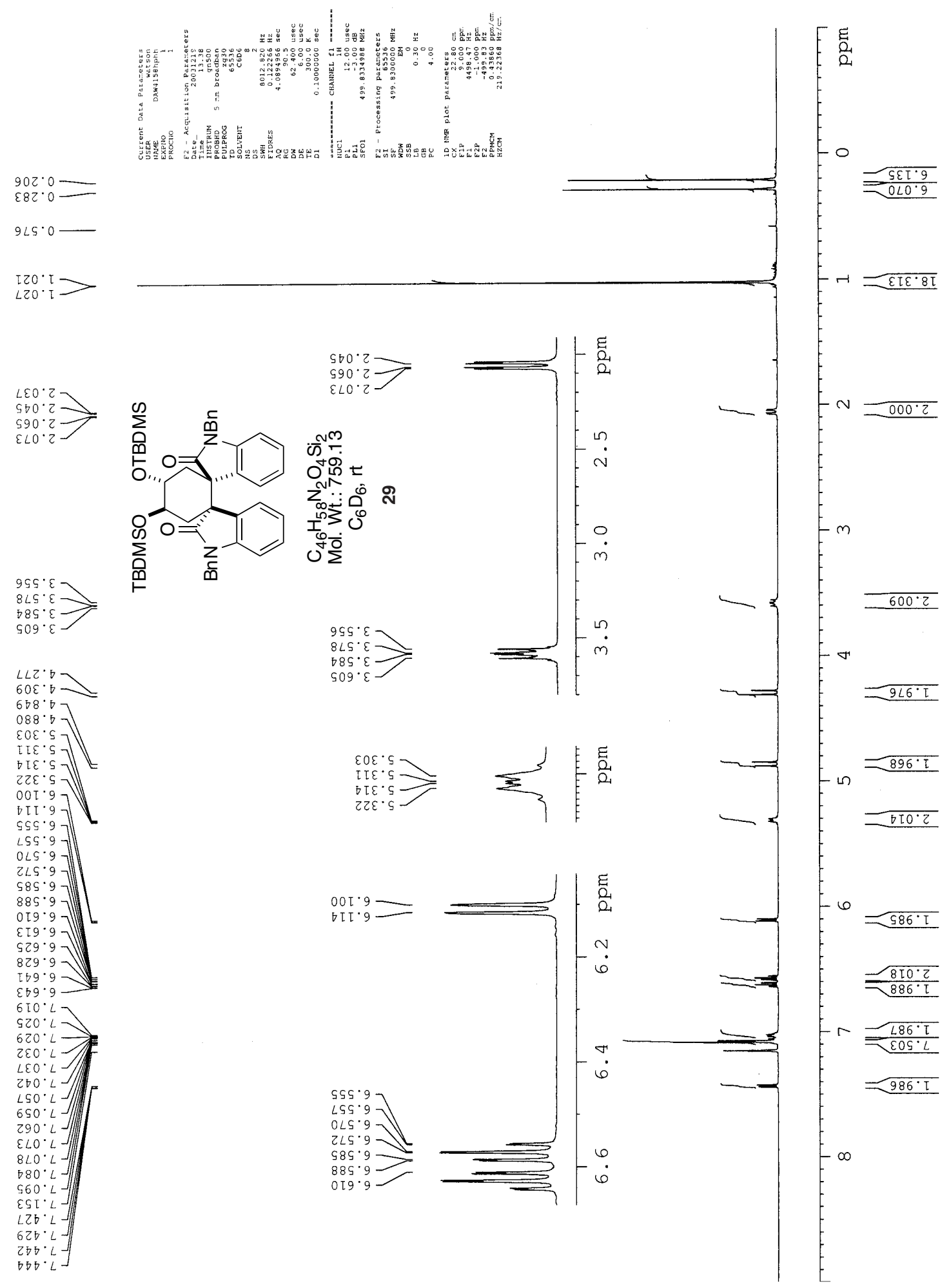


Supporting Information Overman and Watson

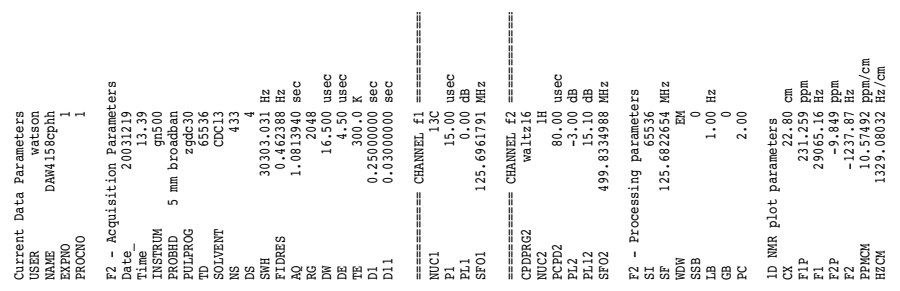

${ }_{90, y-5}^{80,5}=$
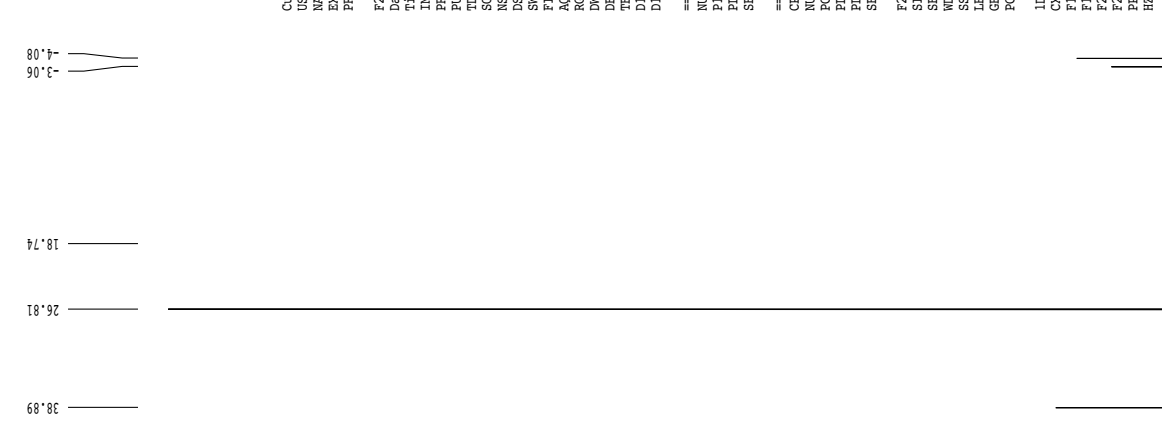

भL 2 —

$00 \cdot \varepsilon \varsigma$
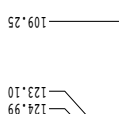

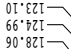

$0 \sigma^{\circ} 82 \mathrm{II}$

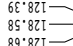

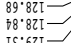

TI.
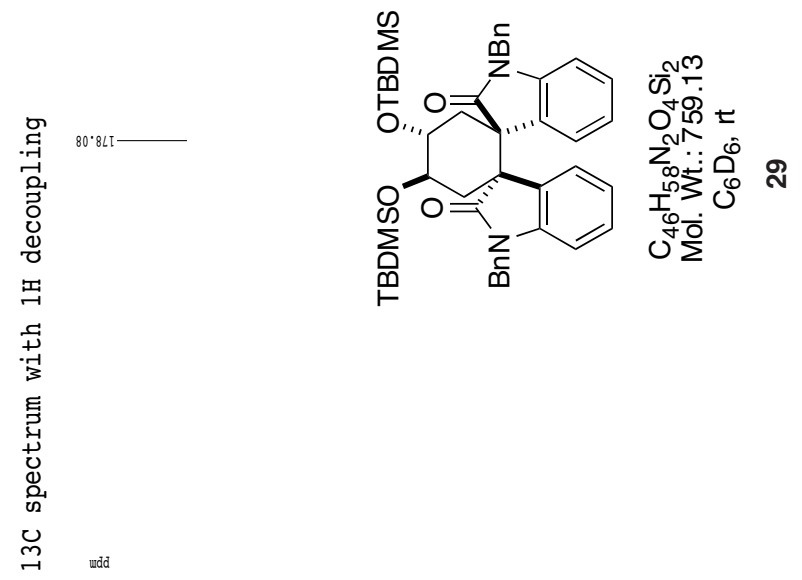
Supporting Information Overman and Watson
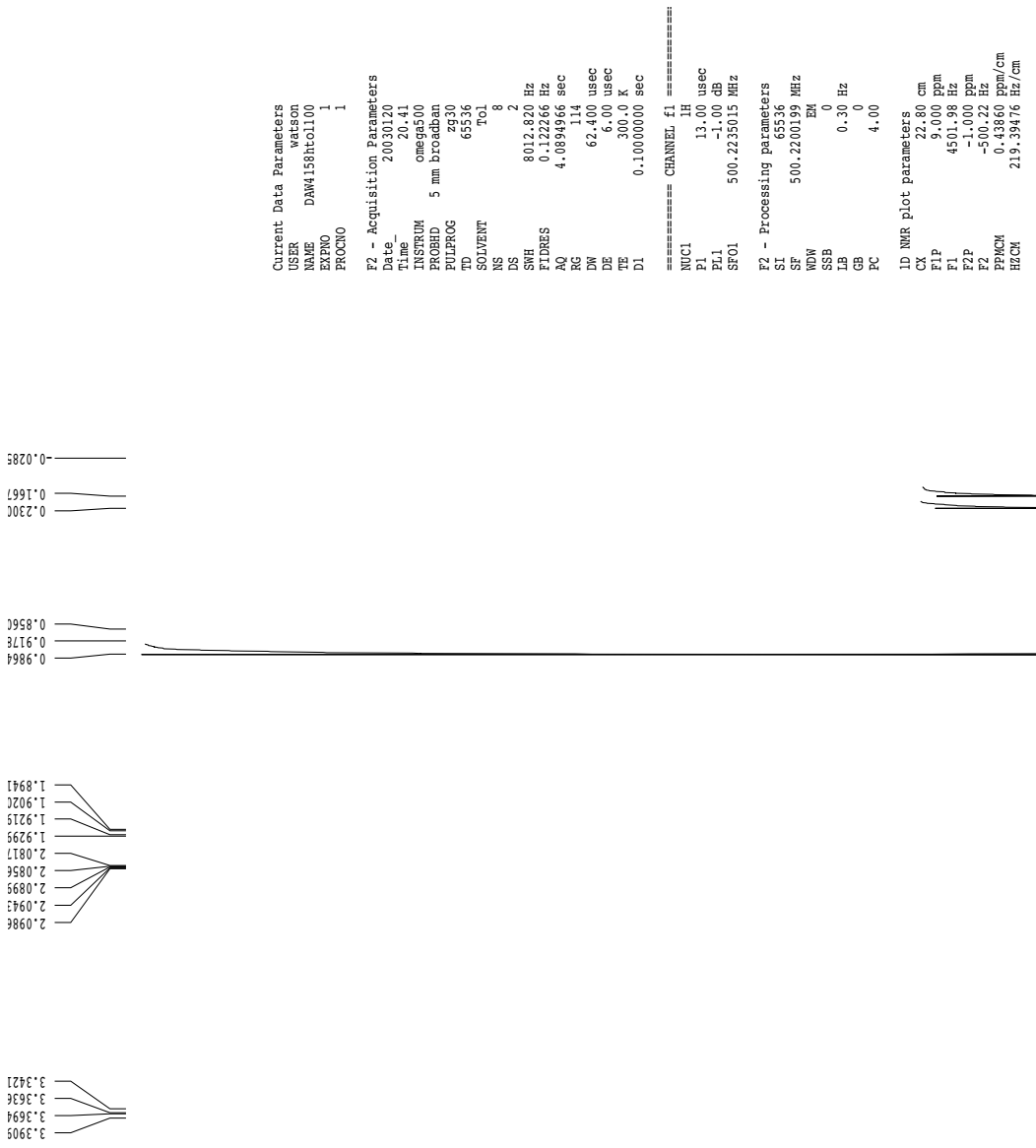

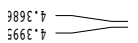

${ }^{3078^{\circ} \cdot 7}=$

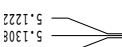

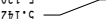

${ }_{16619}^{625} \cdot$

$2561^{\circ} \cdot 9$
35659

1.955: 97

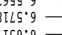

$\frac{-159 \cdot 9}{5999 \cdot 9}$

1
$1199^{\circ} \cdot 9$

$326^{\circ} \cdot 9$

$1900^{\circ} \mathrm{L}=$

$1950^{\circ} \mathrm{L}=$

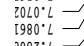

$3988^{\circ} L$
$550 \varepsilon^{\circ} L$

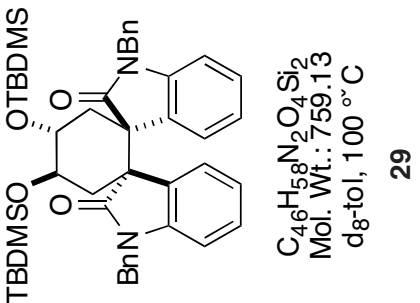

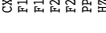




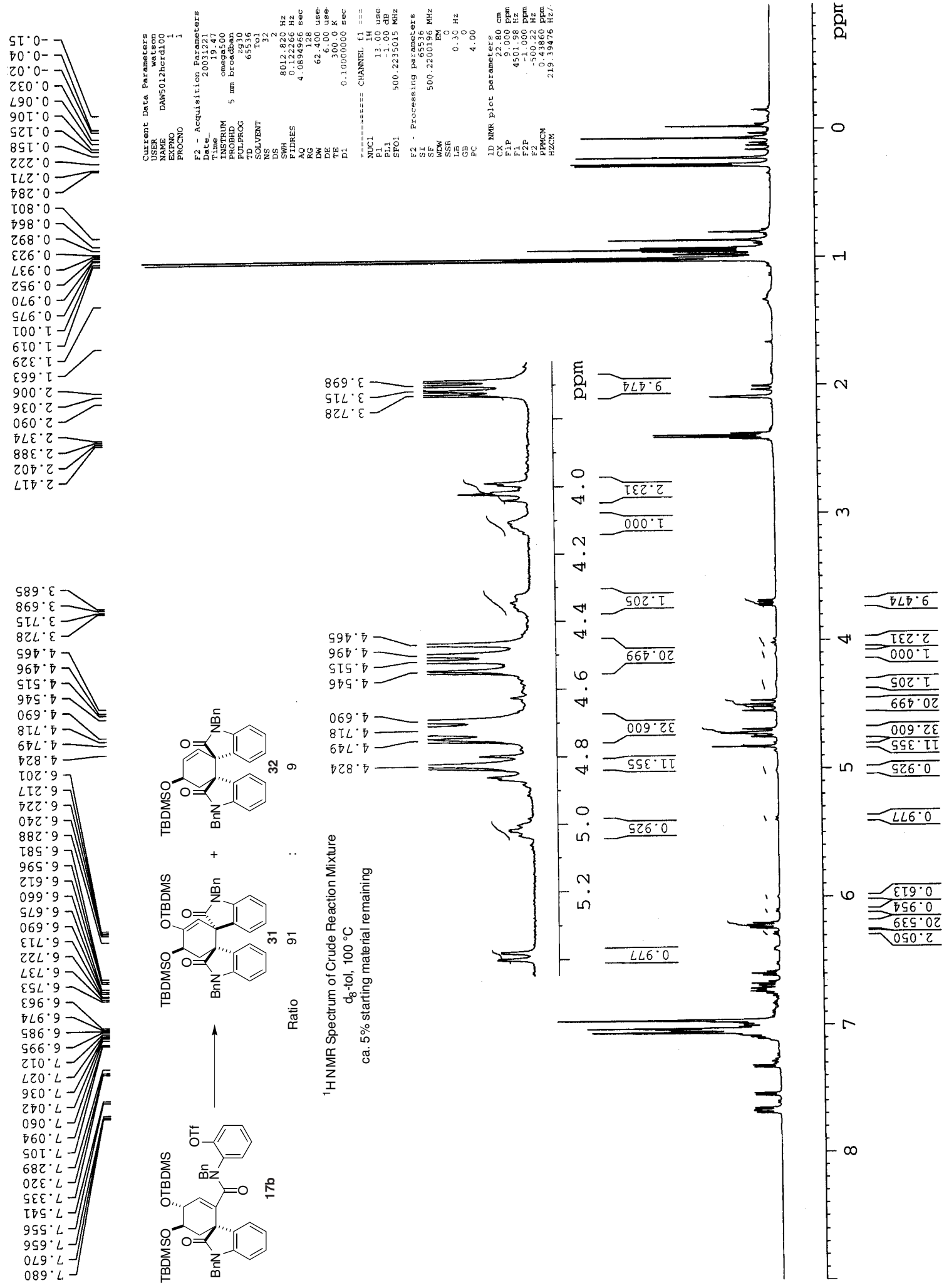




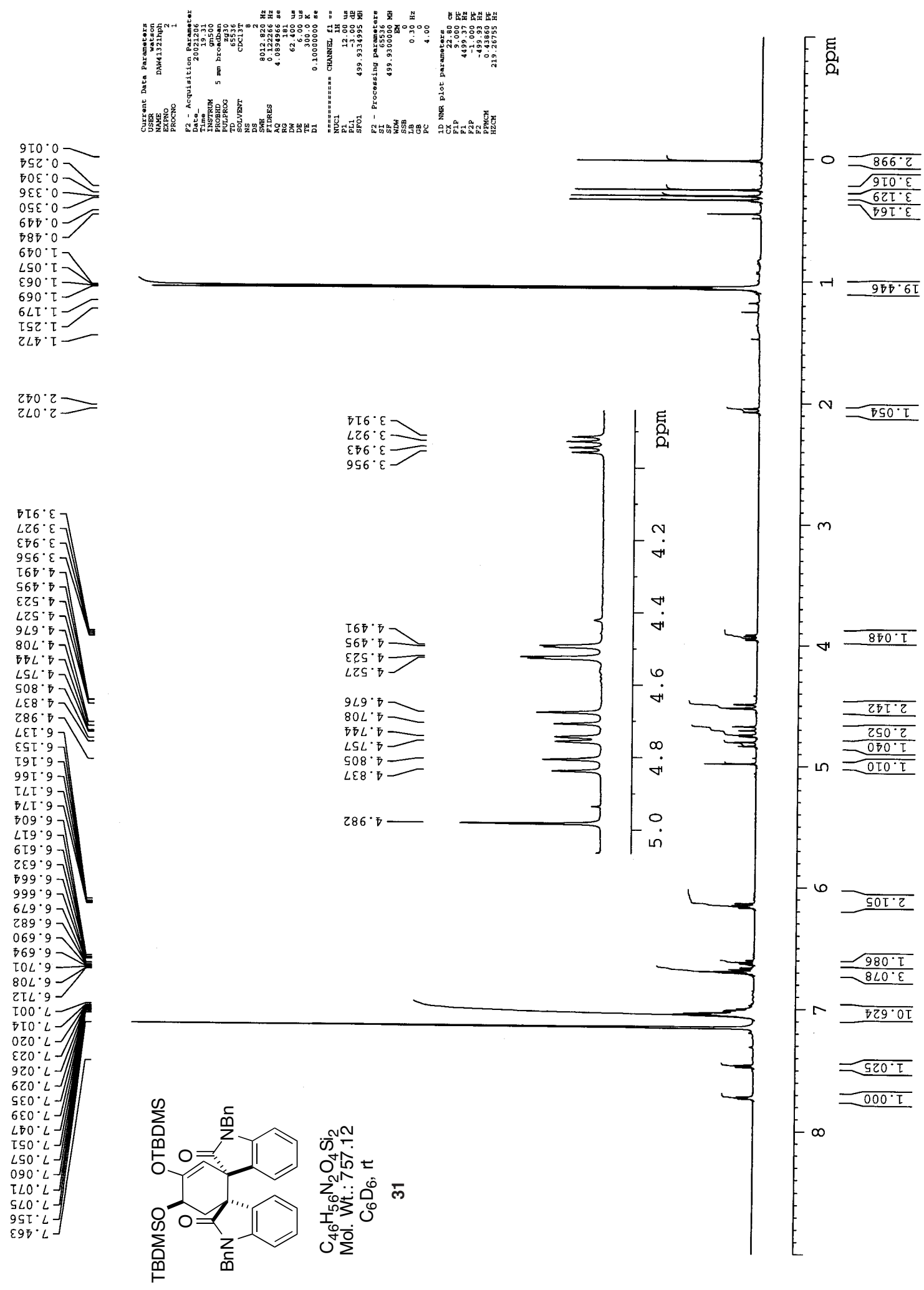



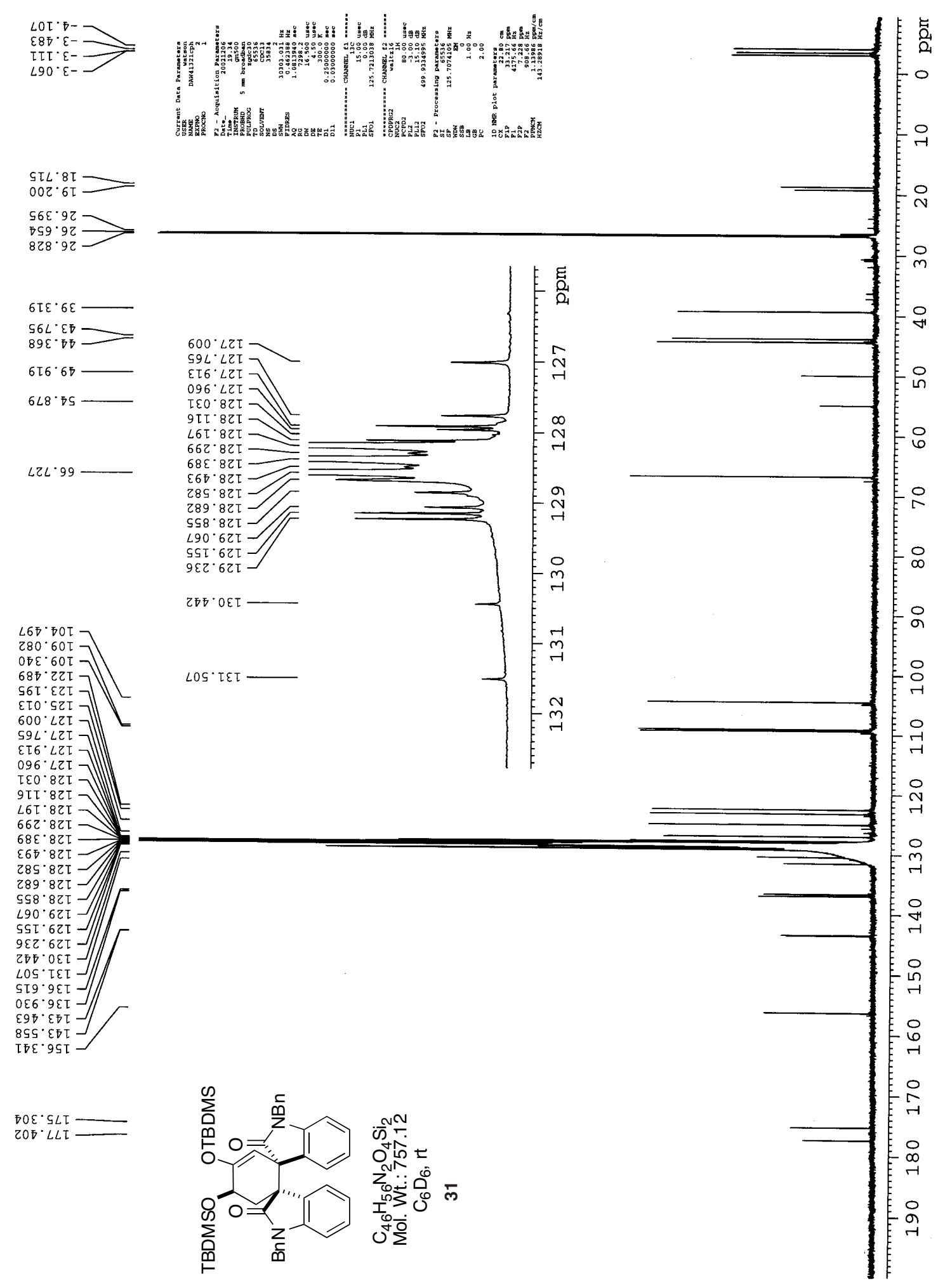
Supporting Information Overman and Watson
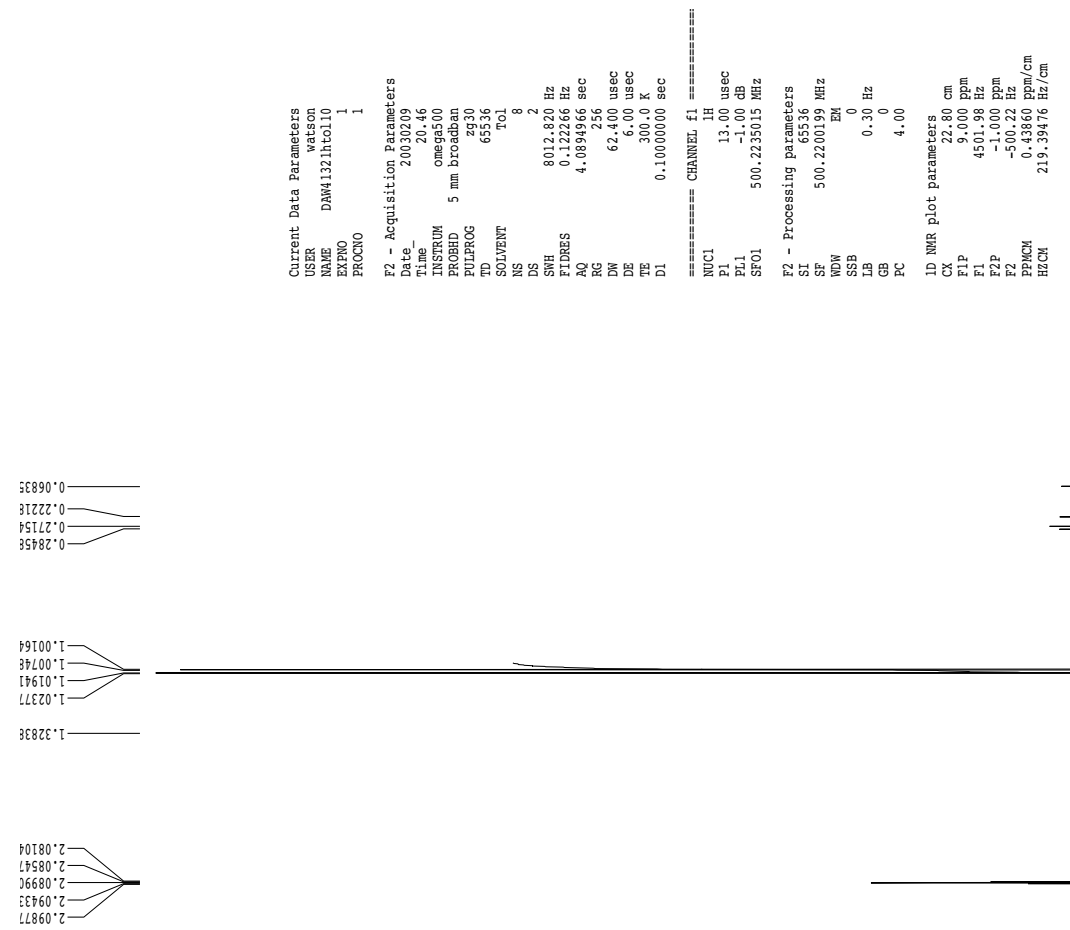

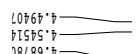

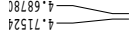

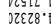

28728.7

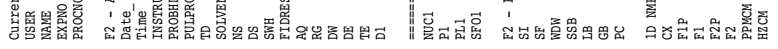
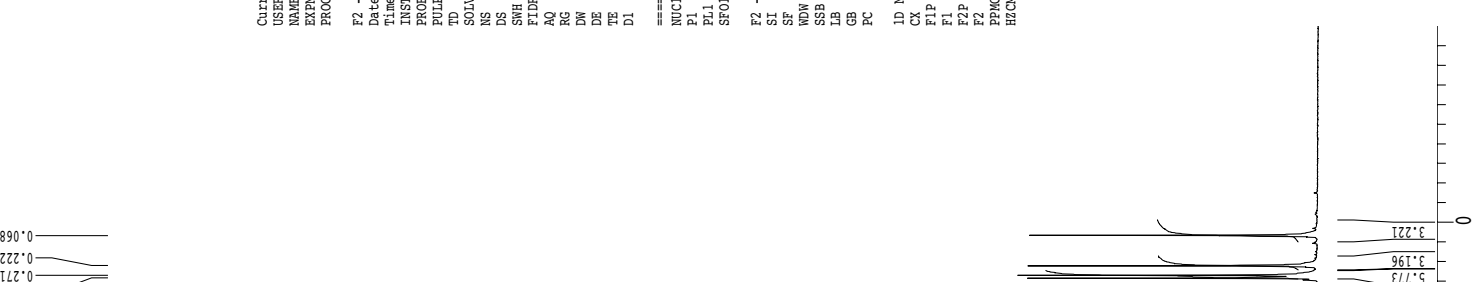


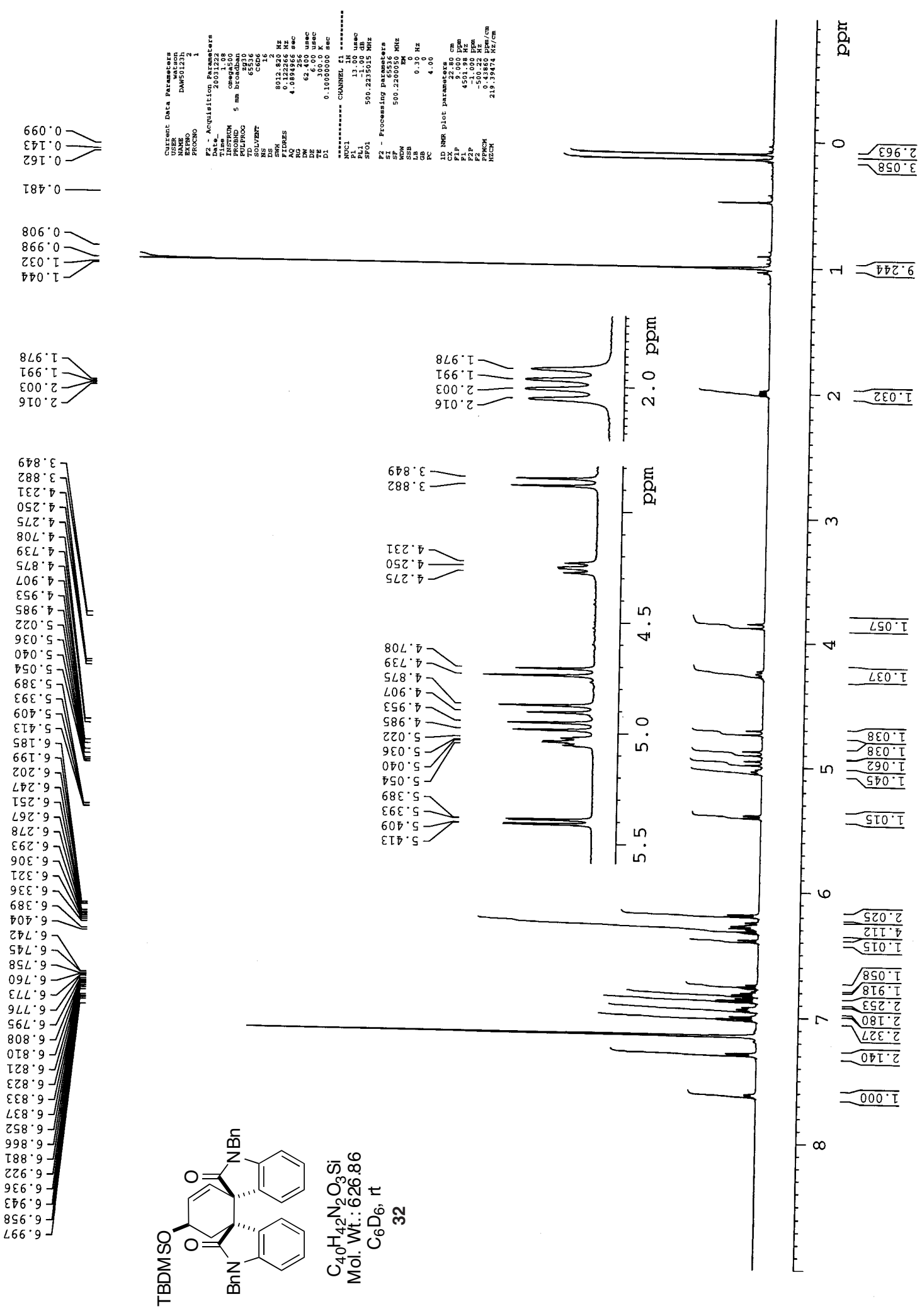



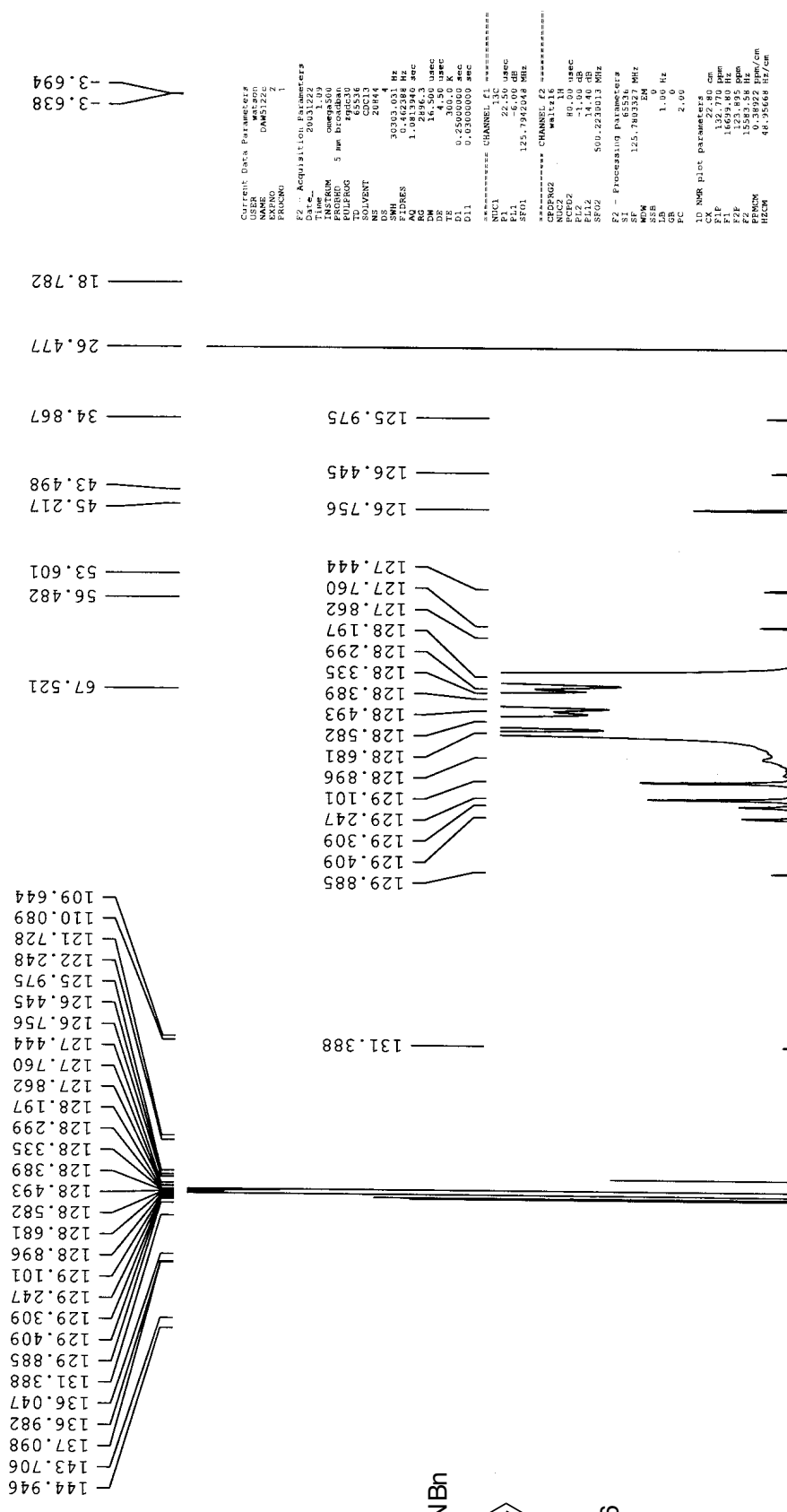

$8 E L \cdot O L I=$
$608 \cdot G L I=$

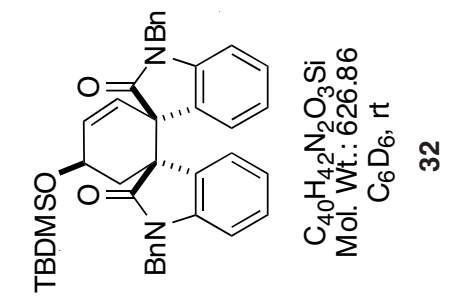

SL6.SZI

SดD.9ZI -

9SL.9ZI

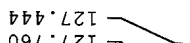
$09 L^{\circ} \mathrm{LZI} \longrightarrow$ $\angle 6 \mathrm{~L} \cdot 82 \mathrm{LI}$ $66 z \cdot 8 Z \mathrm{I}$

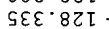

$68 \varepsilon \cdot 8 \mathrm{ZL}$

$\varepsilon 6 t \cdot 8 Z \mathrm{~L}$ $285^{\circ} 82 \mathrm{~L}$

$968.8 \mathrm{ZI}$

IOI. 62 T

$\angle B Z \cdot 6 Z T$

$60 \varepsilon^{\circ} 6 Z \tau$

$607 \cdot 62 \mathrm{I}$

$588^{\circ} 62 \mathrm{I}$

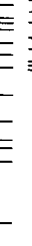

$88 \varepsilon^{\cdot} \cdot \tau \varepsilon$
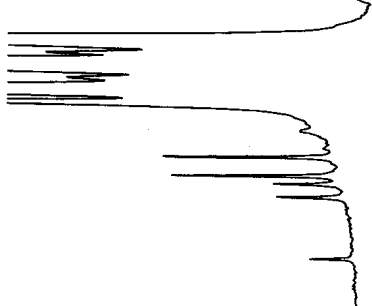

3

E

-
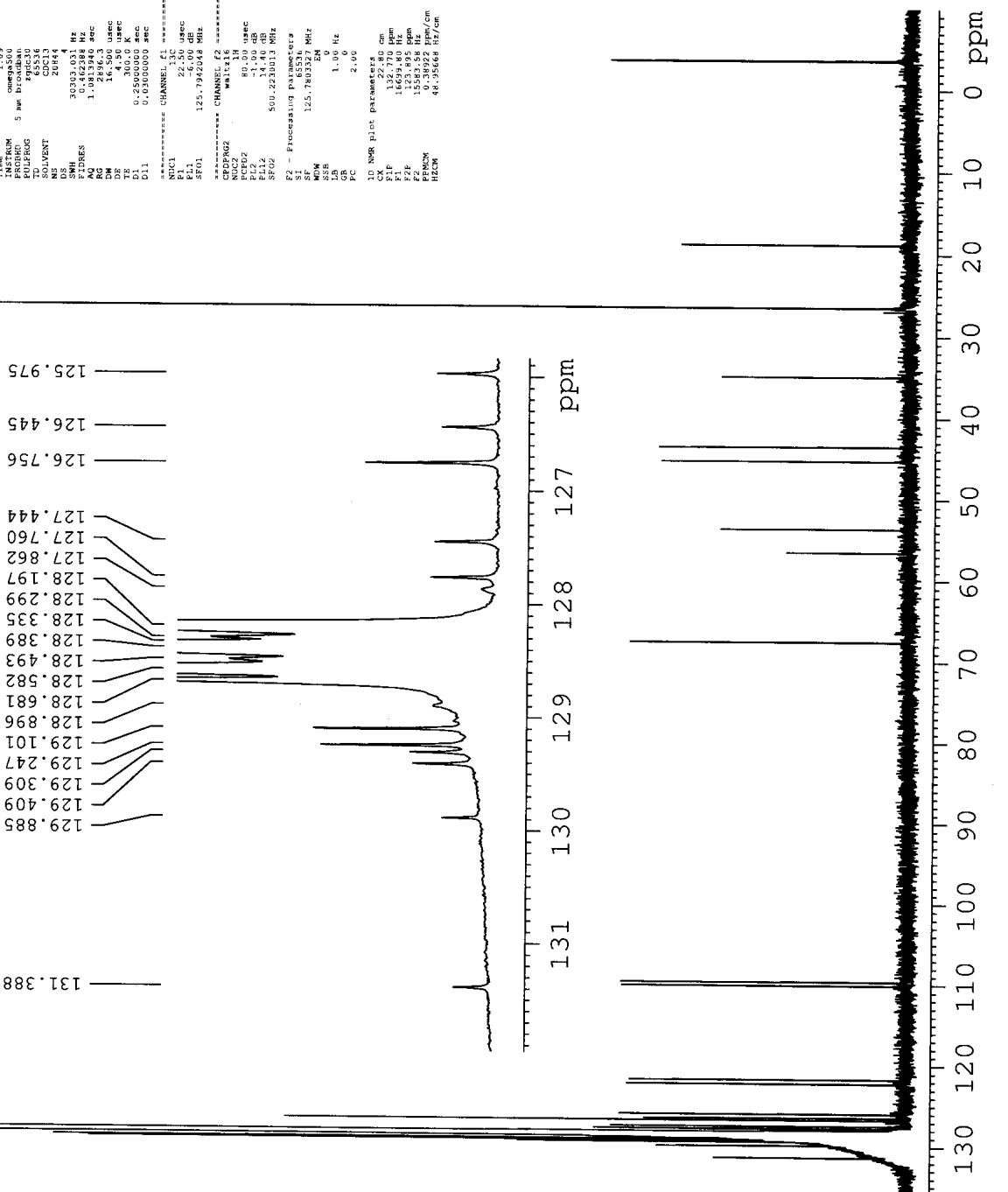

$=$

E앙

E 응

8

$=$

$=\stackrel{-}{\sim}$

$\frac{2}{2}$

E음

$=0$

웅

.

$=0$

更

= 을

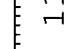

$\stackrel{\circ}{N}$

$\rightarrow$

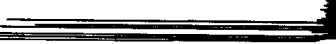

年

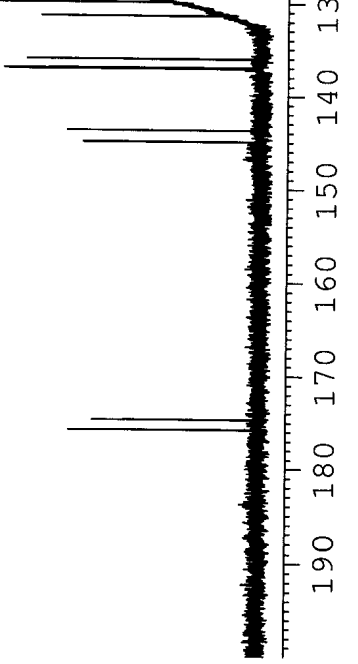



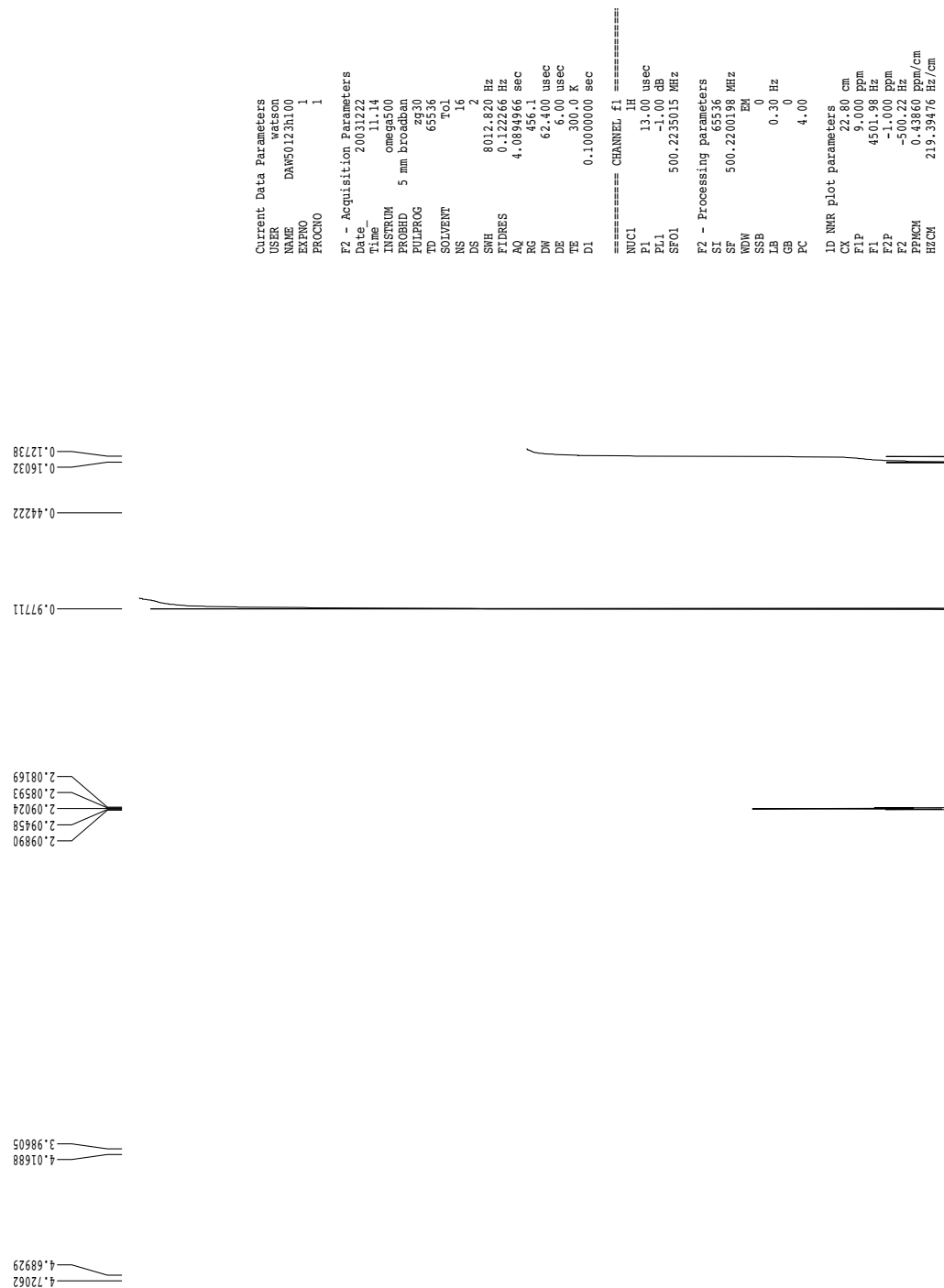

$2926 L^{\circ} 7 \bar{\square}$

рт्920

$\varepsilon L u \varepsilon \cdot \varepsilon^{-}$

$\varepsilon \angle L 6 \varepsilon^{\circ} \varsigma$

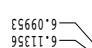

BetL ${ }^{\circ} \cdot 97$

$\nabla 9982 \cdot 9$

${ }_{0968: 9} 99$

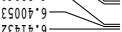

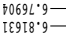

SEOC8.9-

LT6978.9

$09618^{\circ} 9$

\begin{tabular}{l}
$80588^{\circ} \cdot 9-1$ \\
\hline $066^{\circ} 9-1$
\end{tabular}

201560.

$26966^{\circ} \cdot 9-$

$\angle \angle 920 \cdot:-$

$92060^{\circ} \mathrm{L}-$

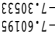

$65999^{\circ}-$
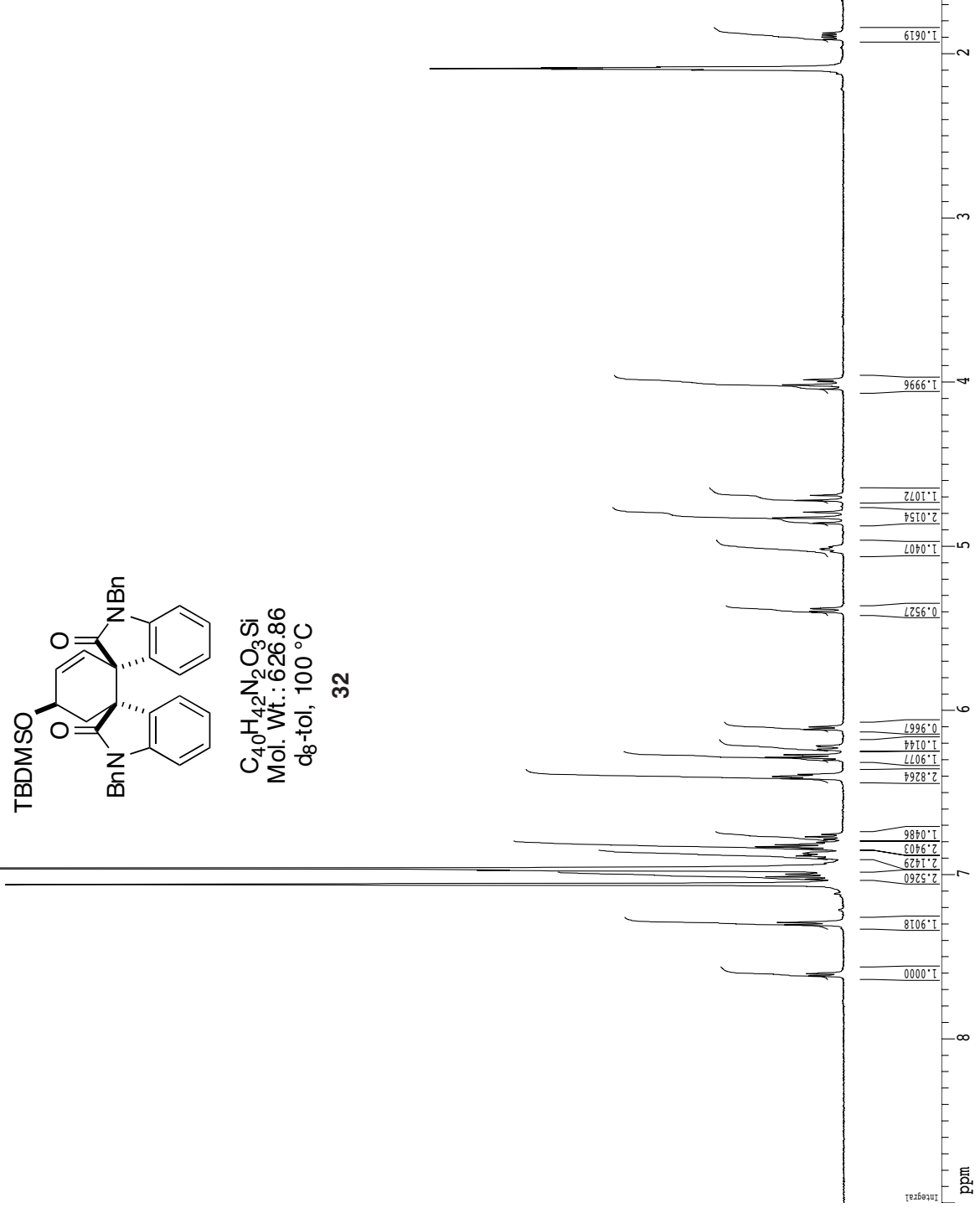


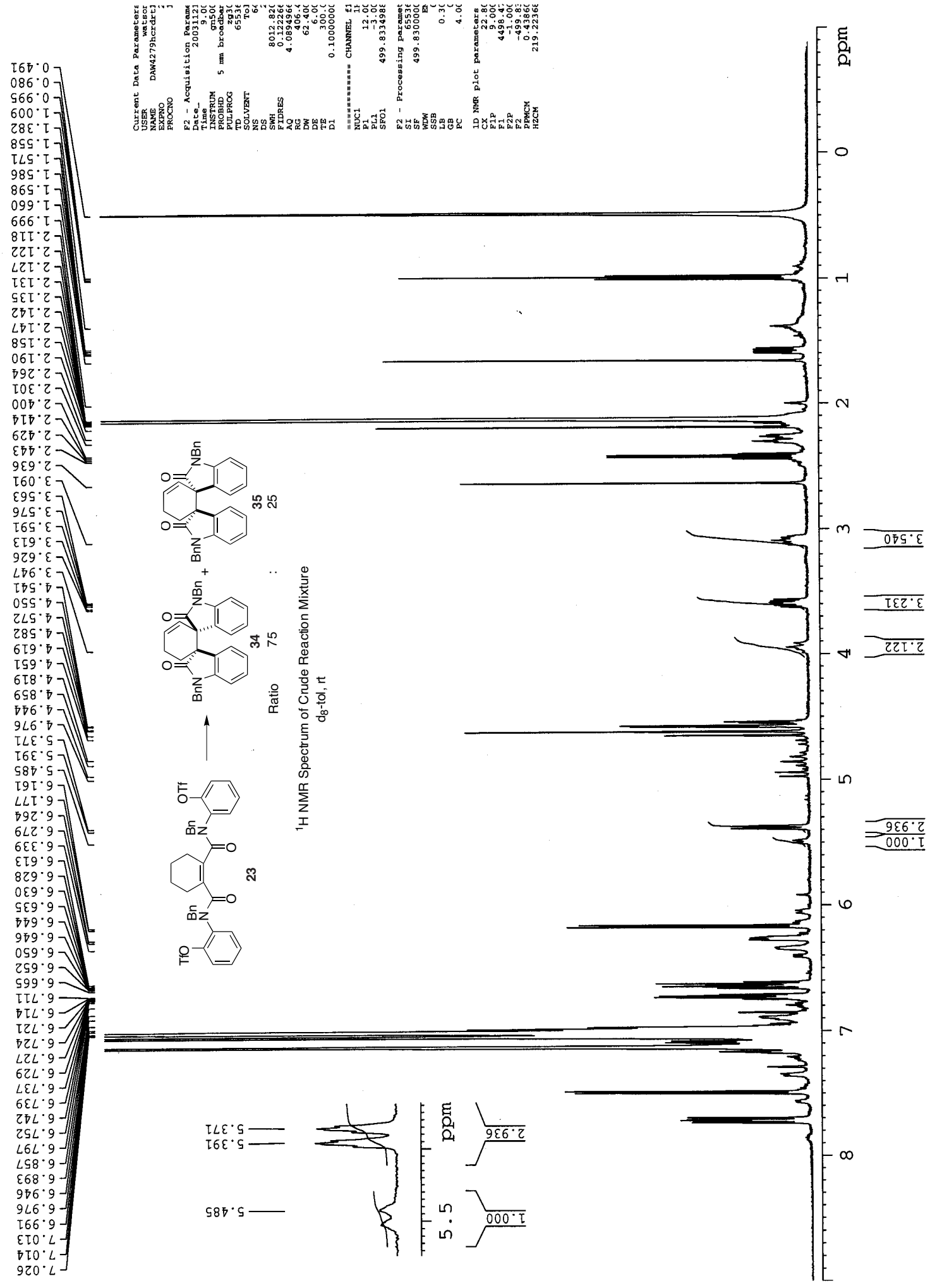



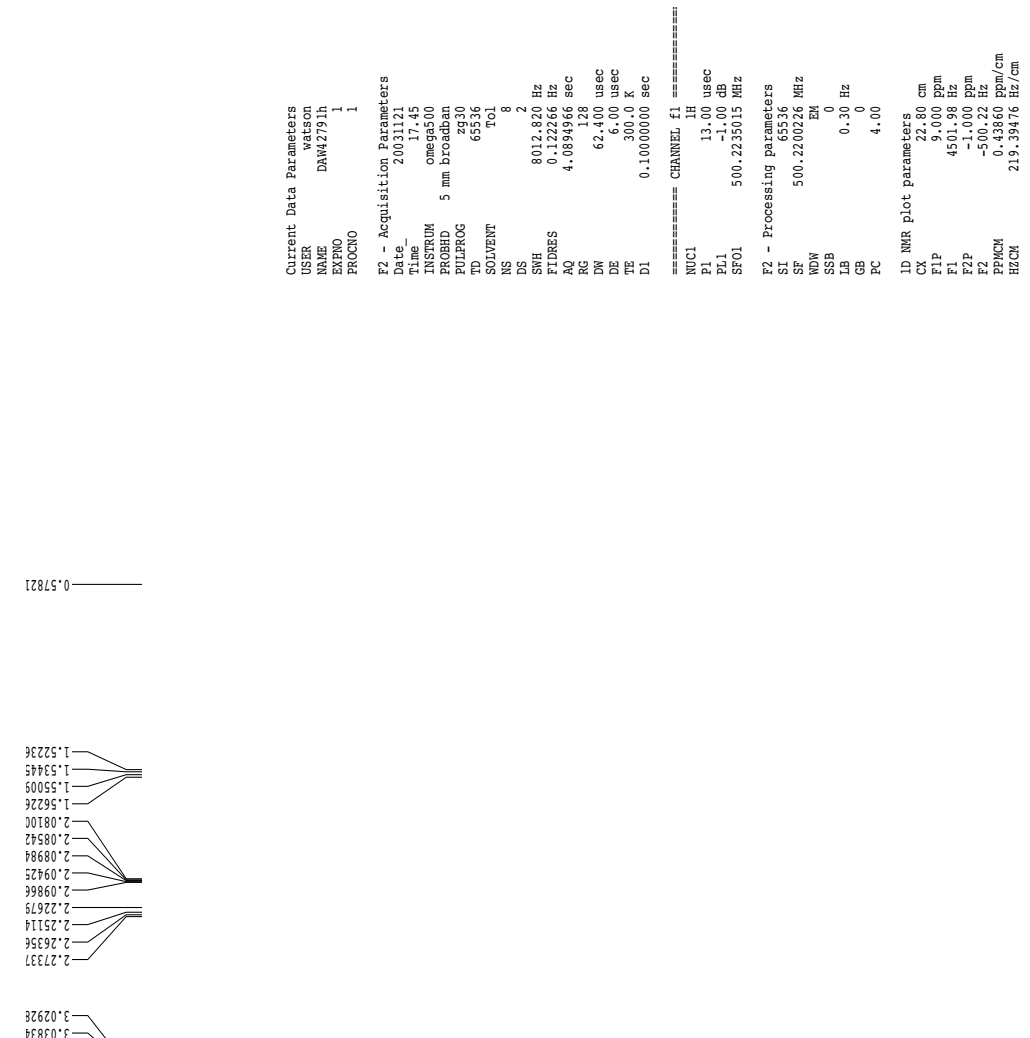

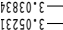

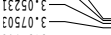

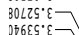

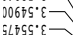

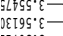

IIL $299^{\circ} \varepsilon$

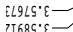

27685' $\varepsilon=$

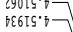

60265' $7-7$

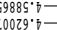

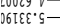

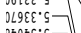

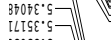

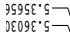

$381[5 \cdot 97$

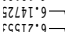

$\left.\begin{array}{l}555[2.9 \\ 50022.9\end{array}\right]$

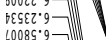

$\left.\begin{array}{l}10085^{\circ} \cdot 9 \\ i \varepsilon \varepsilon 65.9\end{array}\right]$

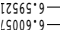

$1.5009 \cdot 9-1$
592009

35809.9
78099.9

3 [ST: 9

$88009 \cdot 9]$

38269.97

$\$ 6669 \cdot 9]$

$\left.\begin{array}{l}66669^{\circ} .9 \\ \forall<\angle 89.9\end{array}\right]$

${ }_{88669}^{8869} \cdot 9$

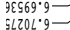
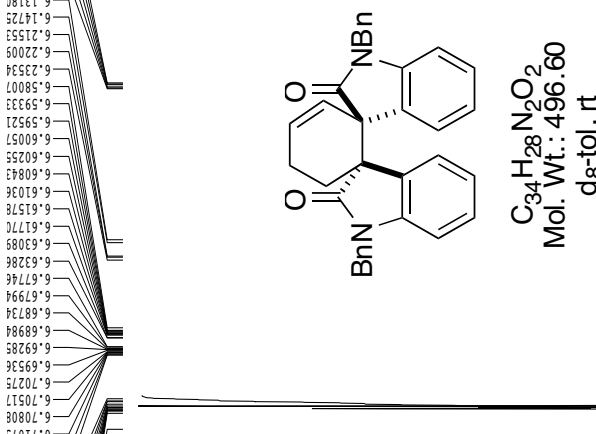

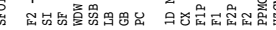

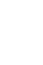


Supporting Information Overman and Watson
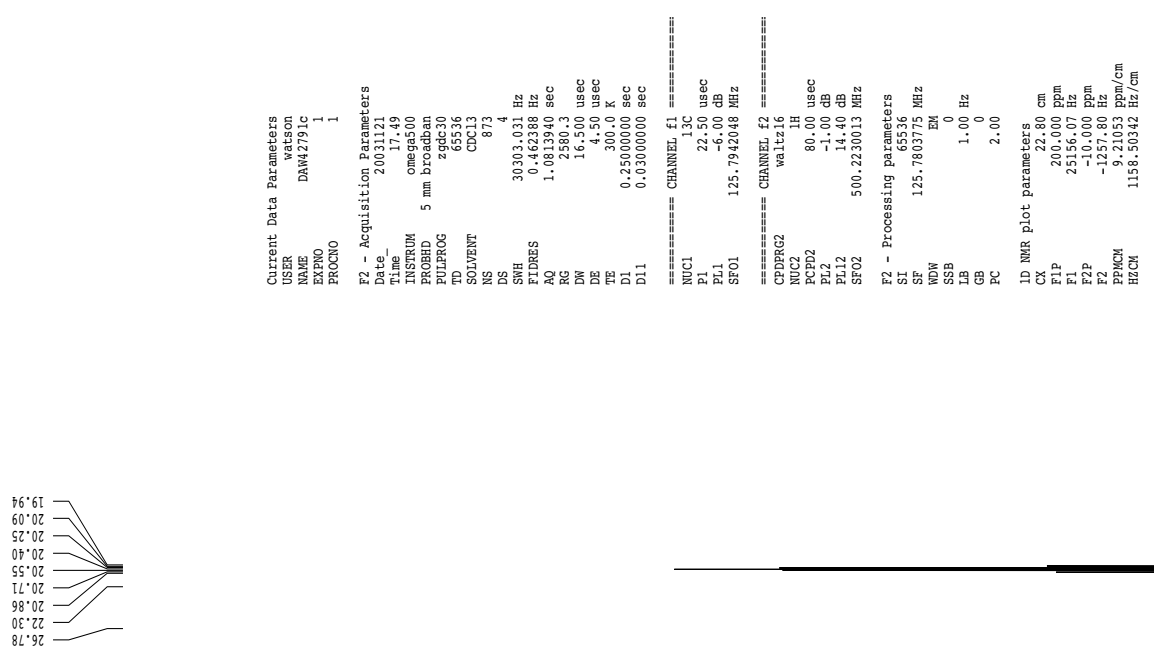

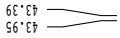

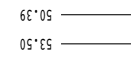

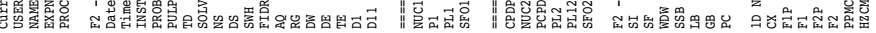
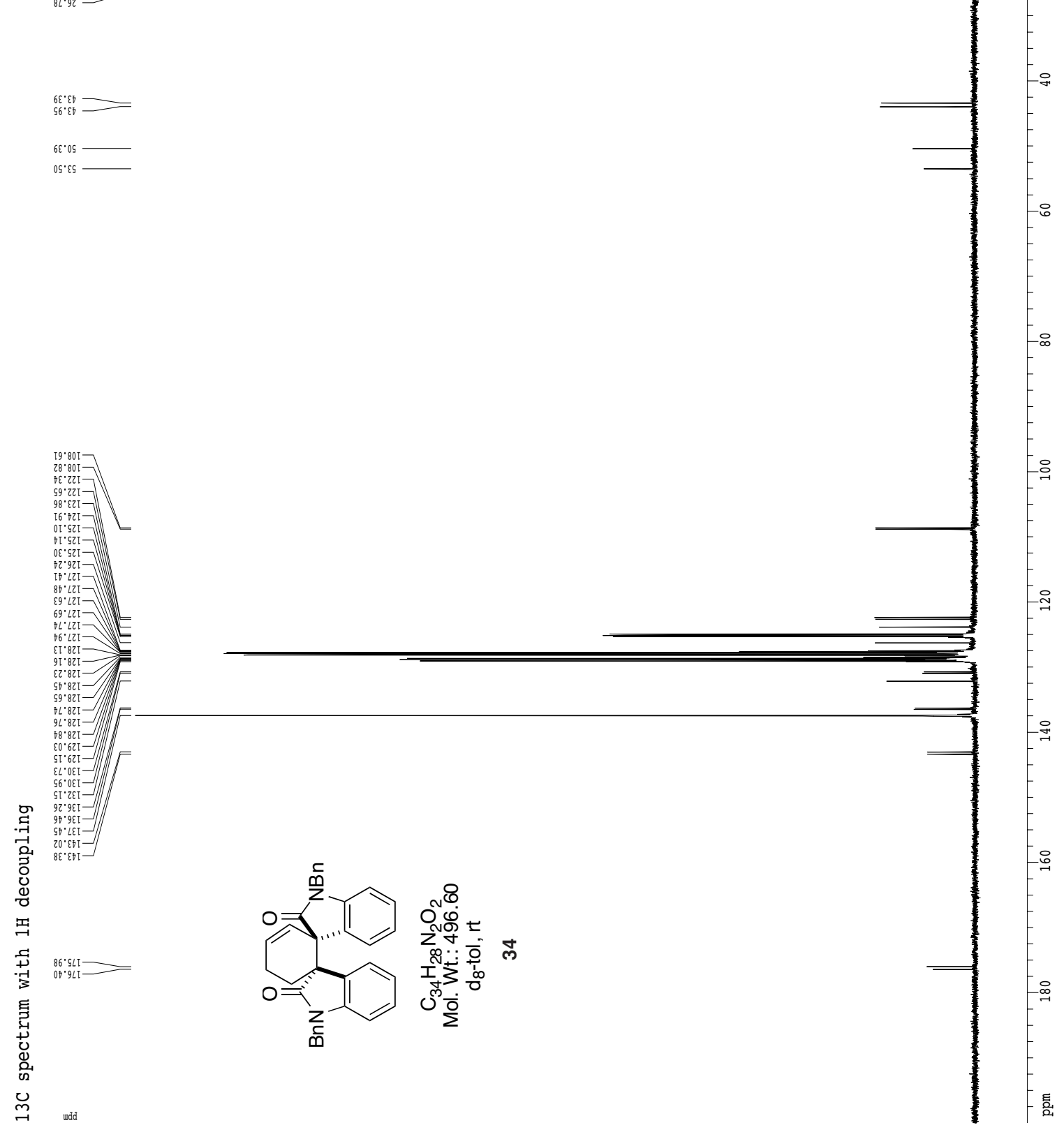
Supporting Information Overman and Watson

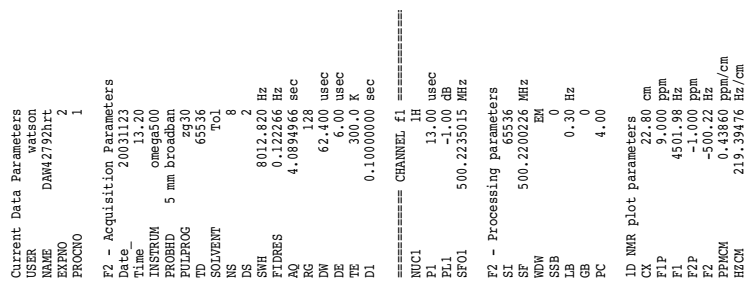

$$
\varepsilon 9729 \cdot 0
$$
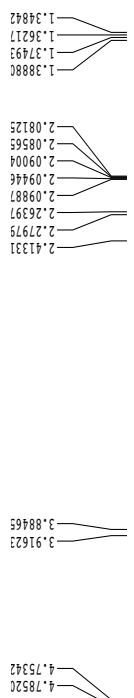

$67228^{\circ} \mathrm{b}$

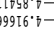

$3<866^{\circ} \mathrm{7}=$

$30059 \cdot 5$

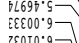

¿EOT0.97]

$\left.\begin{array}{l}88270.9 \\ 00060.97\end{array}\right]$

$\left.\begin{array}{c}58980.9 \\ 1.9660^{\circ}\end{array}\right]$

$3600[967$

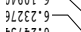

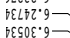

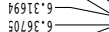

30298.92

$5987: 92$

$36692.9-$

$28958^{\circ} \cdot 9$
$7 L 998^{\circ} \cdot$

(c256.

$50226.9-$

st96.9-
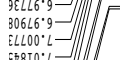

$30<50^{\circ}:-$

$59660^{\circ} L$
ร2tIE. $L-$

- $9952 \varepsilon^{\circ}-1$

톡

3Ltth' $L$

๙

焉 wdd

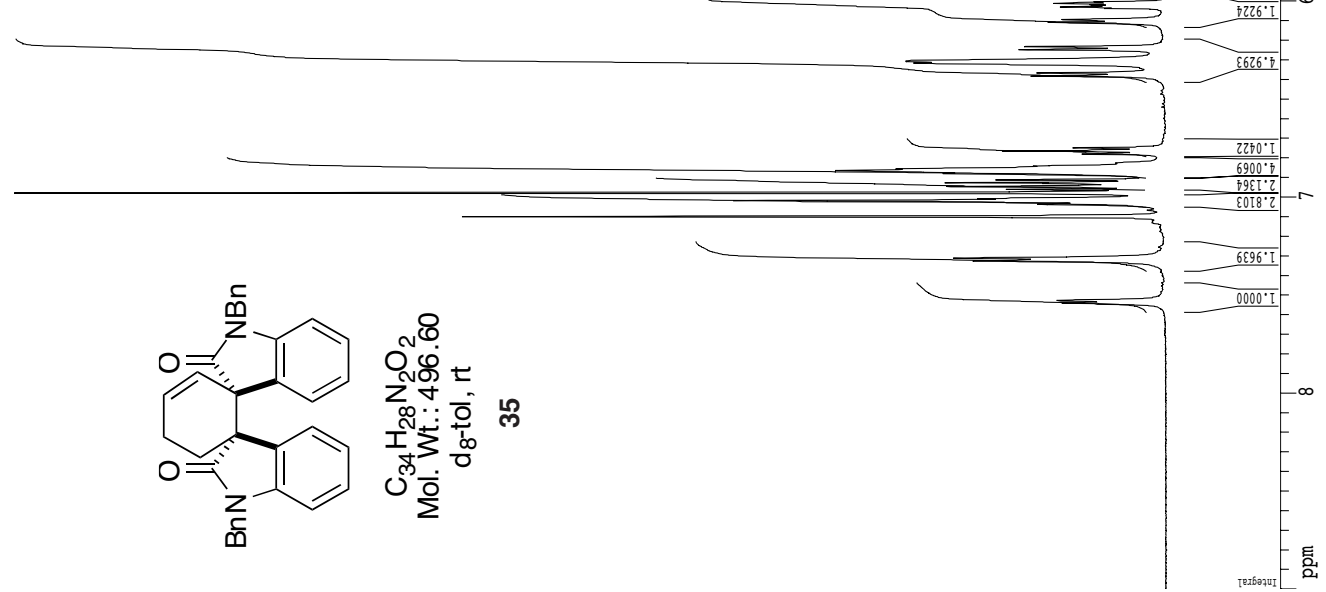


Supporting Information Overman and Watson

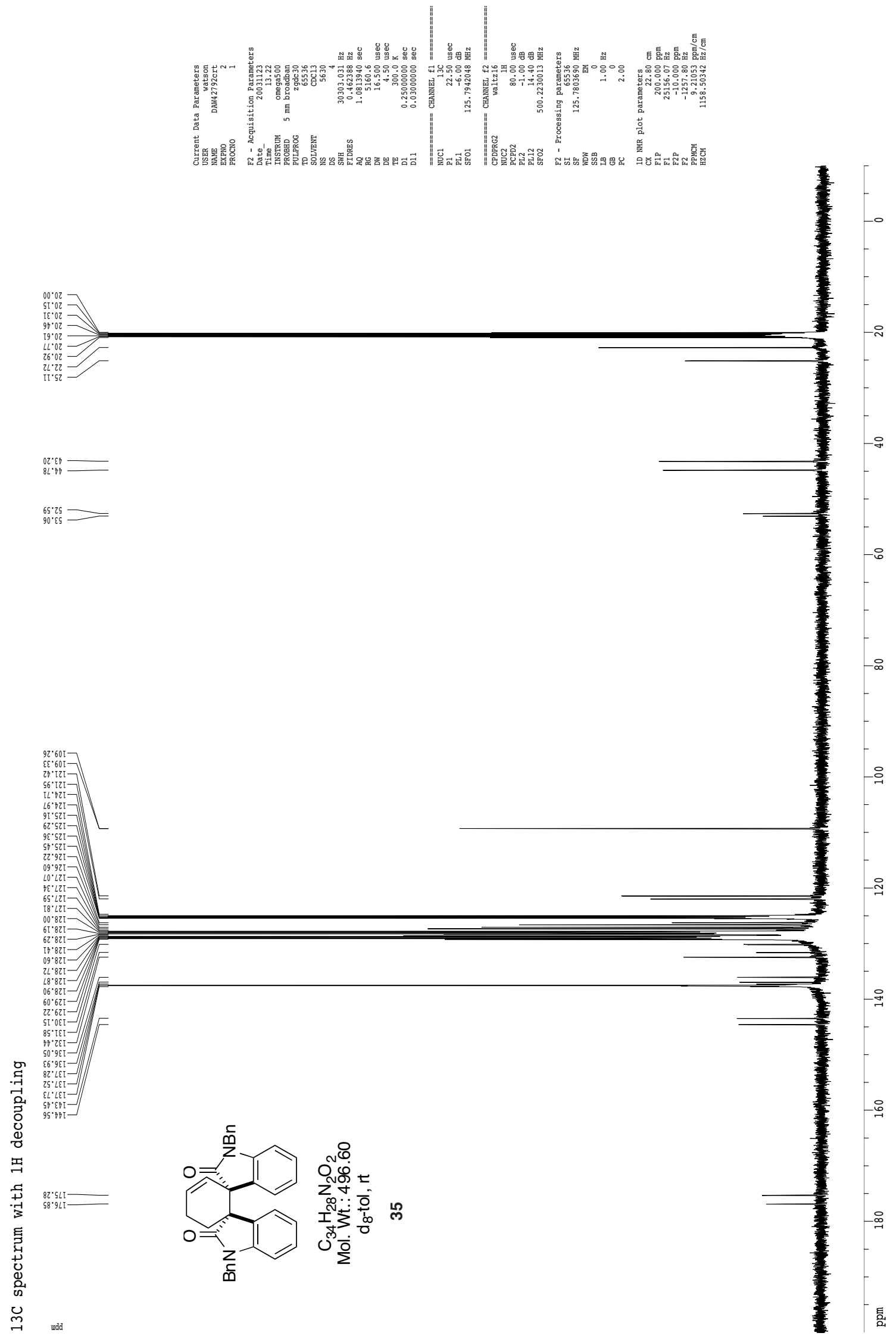


Supporting Information Overman and Watson
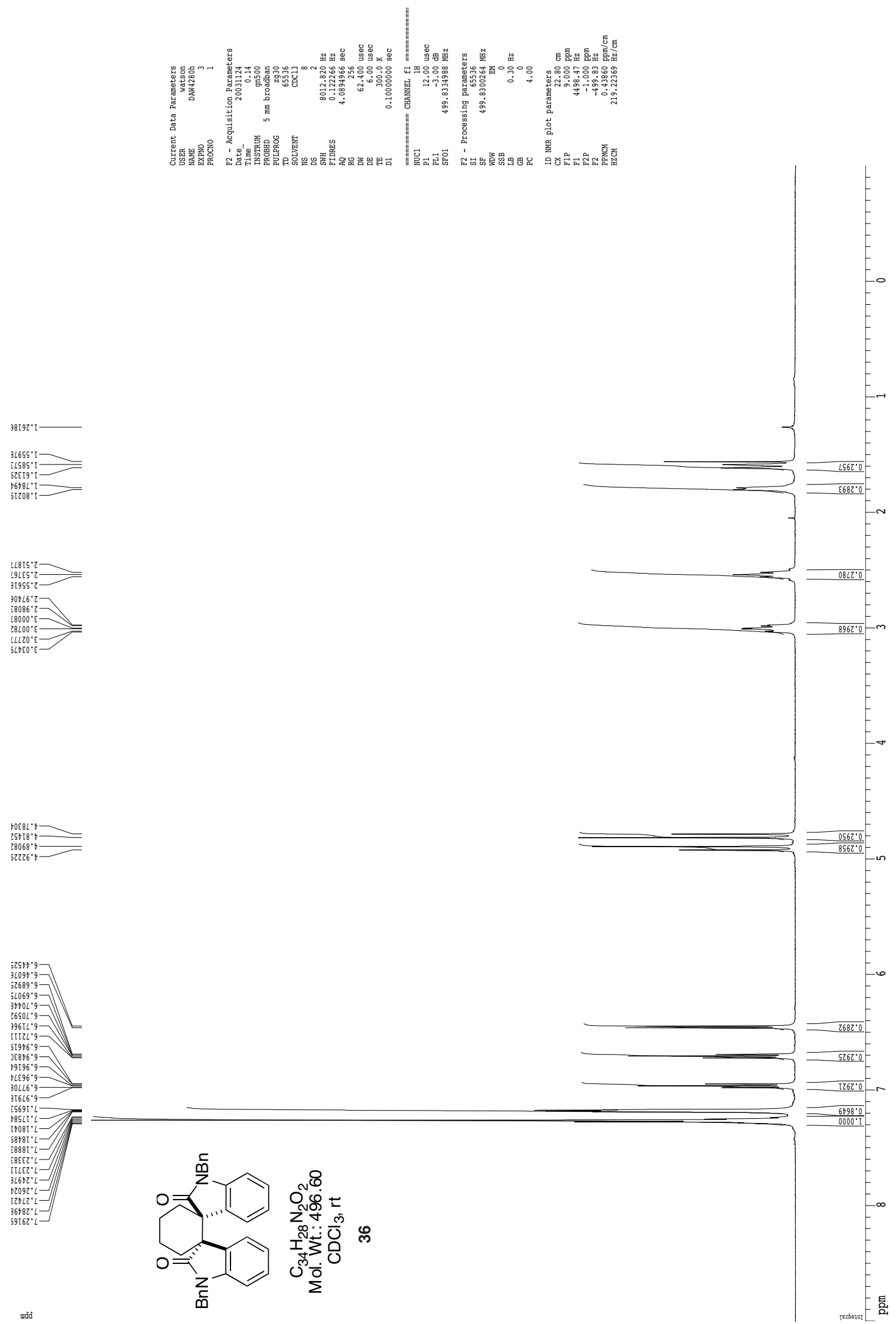

udd 

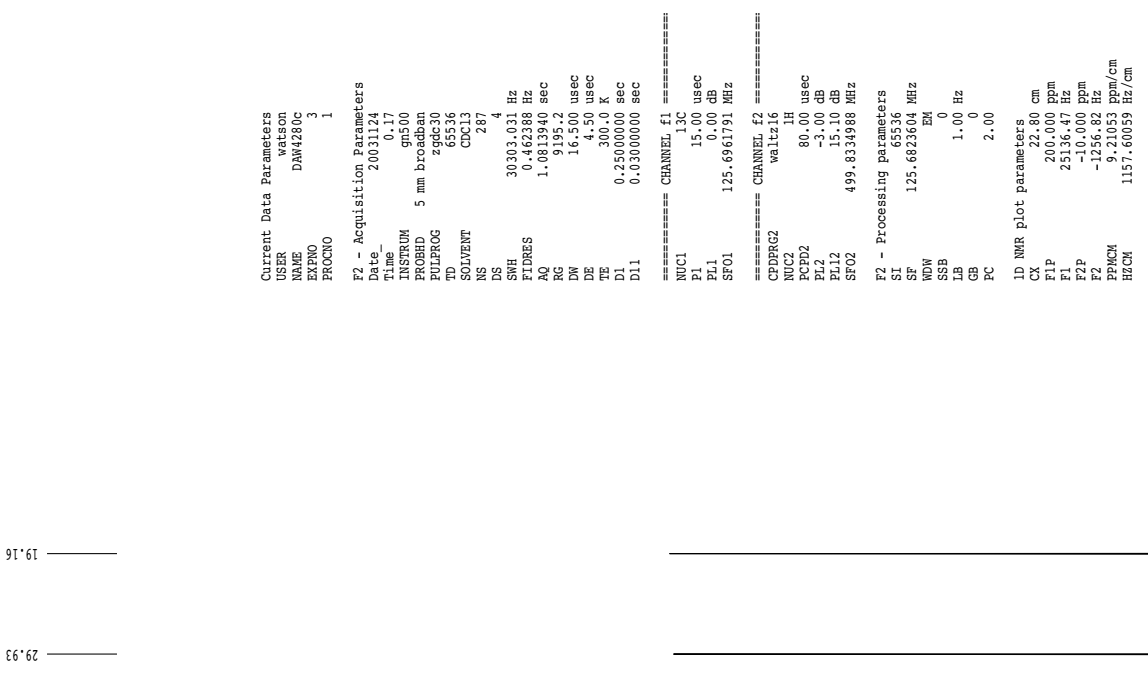

$9 \tau^{\circ} \circ \varepsilon$

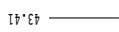

8I'05
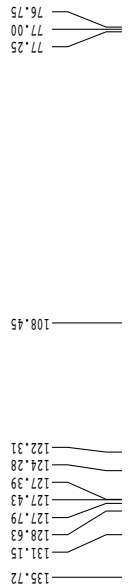

$2 \Gamma^{\top} \mathrm{\tau} \tau$
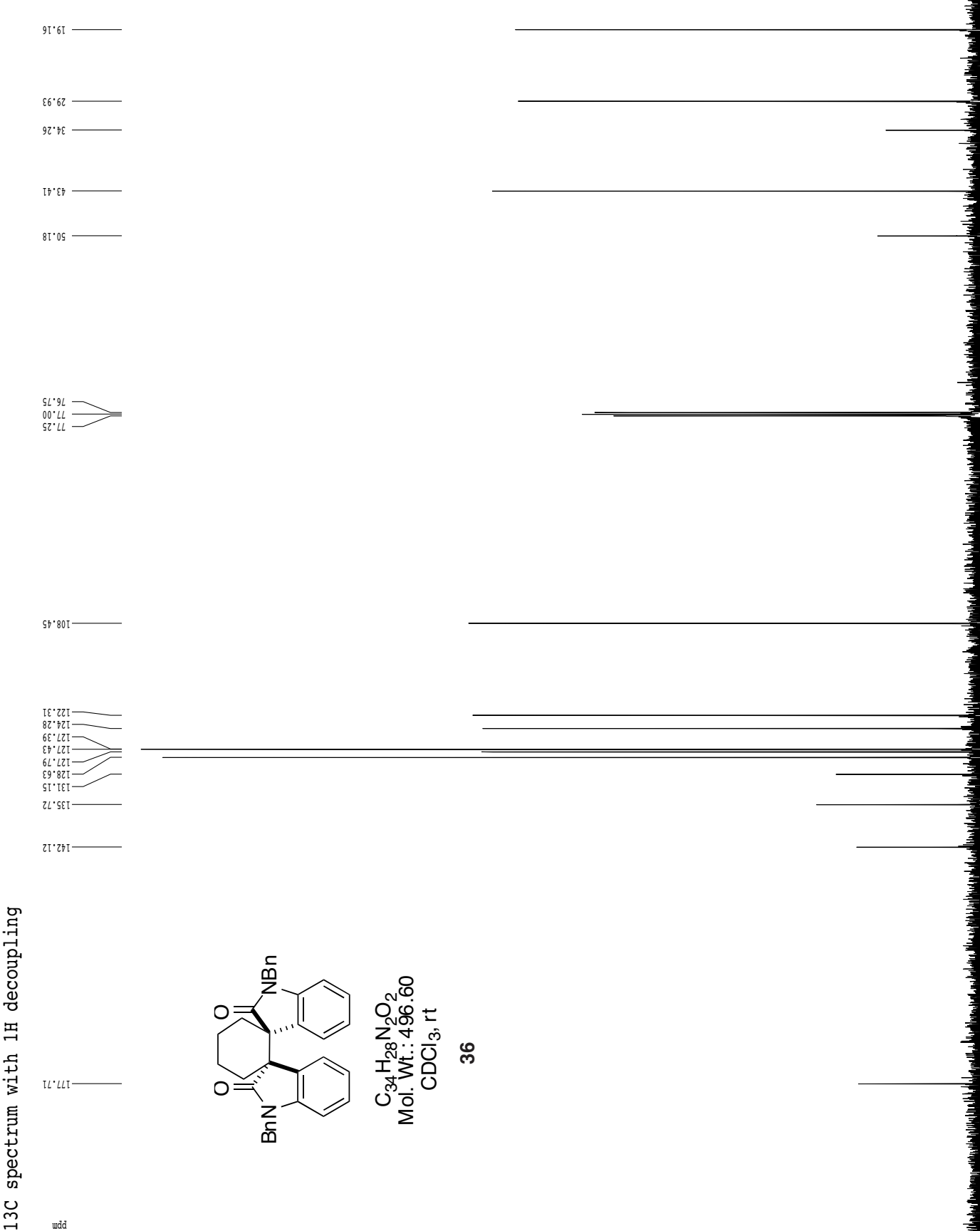